\title{
FARMERS, HUNTERS, AND COLONISTS
}

Interaction Between the Southwest and the Southern Plains

\section{KATHERINE A. SPIELMANN}


Farmers, Hunters, and Colonists 



\section{Farmers, Hunters, and Colonists}

INTERACTION BETWEEN THE SOUTHWEST

AND THE SOUTHERN PLAINS

Edited by Katherine A. Spielmann 
This Open Arizona edition is funded by the National Endowment for the Humanities/Andrew W. Mellon Foundation Humanities Open Book Program.

The University of Arizona Press

www.uapress.arizona.edu

Copyright (c) 1991 by The Arizona Board of Regents

Open-access edition published 2018

ISBN-13: 978-0-8165-3786-0 (open-access e-book)

The text of this book is licensed under a Creative Commons AttributionNonCommercial-NoDerivatives 4.0 International License (CC BY-NC-ND 4.0), https://creativecommons.org/licenses/by-nc-nd/4.0/.

Typographical errors may have been introduced in the digitization process.

The Library of Congress has cataloged the print edition as follows:

Farmers, hunters, and colonists : interaction between the Southwest and the southern plains / edited by Katherine A. Spielmann.

p. $\mathrm{cm}$.

Includes bibliographical references and index.

ISBN 0-8165-1224-8

1. Pueblo Indians-Commerce. 2. Pueblo Indians-Agriculture.

3. Pueblo Indians-History. 4. Barter-Great Plains-History.

5. Barter-Southwest, New-History. 6. Frontier and pioneer lifeGreat Plains-History. 7. Frontier and pioneer life-Southwest, New-History. I. Spielmann, Katherine A.

E99.P9F37 1991

$303.4^{\prime} 82^{\prime} 0978-\mathrm{dc} 20$

91-11619

CIP

British Library Cataloguing in Publication data are available. 


\section{Contents}

Preface

I Interaction Among Nonhierarchical Societies

KATHERINE A. SPIELMANN

2 Some Unexplored Aspects of Mutualistic Plains-Pueblo Food Exchange

JOHN D. SPETH

3 Coercion or Cooperation? Plains-Pueblo Interaction in the Protohistoric Period

KATHERINE A. SPIELMANN

4 Evidence for the Manufacture of Southwestern-Style Culinary Ceramics on the Southern Plains

IUDITH A. HABICHT-MAUCHE

5 Upland Prehistoric Maize Agriculture in the Eastern Rio Grande and Its Peripheries

DAVID H. SNOW

6 Texas Panhandle-Pueblo Interactions from the Thirteenth Through the Sixteenth Century 
vi Contents

7 Ecology and Exchange: The Dynamics of Plains-Pueblo Interaction

TIMOTHY G. BAUGH

8 Changing Contexts of Pueblo Adaptations,

A.D. $1250-1600$

DAVID R. WILCOX

9 Economic Perspectives on the Comanchero Trade FRANCES LEVINE

Bibliography

Index 


\section{Contributors}

TIMOTHY G. BAUGH

Department of Archaeology, Boston University, 675 Commonwealth Avenue, Boston, Massachusetts 022 I 5

JUDITH A. HABICHT-MAUCHE

Board of Studies in Anthropology, University of California,

Santa Cruz, California 95064

FRANCES LEVINE

Santa Fe Community College, P.O. Box 4I87, or 1677 Cerro

Gordo Road, Santa Fe, New Mexico 8750 I

CHRISTOPHER LINTZ

Mariah Associates, Inc., I 700 South Lamar, Suite 240, Austin,

Texas 78704

DAVID H. SNOW

Cross-Cultural Research Systems, 826-A 3 Camino de Monte

Rey, Santa Fe, New Mexico 8750 I

JOHN D. SPETH

Museum of Anthropology, University of Michigan, Ann Arbor,

Michigan 48 I09

KATHERINE A. SPIELMANN

Department of Anthropology, Arizona State University, Tempe, Arizona 85287

DAVID R. WILCOX

Museum of Northern Arizona and Department of Anthropology, Northern Arizona University, Flagstaff, Arizona 8600 I 



\section{Preface}

People follow the cows [bison], hunting them and tanning their skins to take to the settlements in the winter to sell, since they go there to pass the winter.

- CASTAÑeda, CHRONicler of THE CORONADO EXPEDITION

In 1540 the first expedition to explore the Southwest, that of Francisco Vásquez de Coronado, witnessed the exchange between eastern border Pueblo and southern Plains populations documented by Castañeda (Winship I 896, 279). Later expeditions in the sixteenth century, and colonists in the seventeenth, also noted an ongoing PlainsPueblo trade in foodstuffs and manufactured items. In the twentieth century, historians have analyzed the changes in Plains-Pueblo interaction that resulted from the presence of Spanish colonists and access to their goods, while archaeologists have produced evidence of prehistoric Plains-Pueblo interaction. Although myriad data exist concerning relations between these two regions, no attempt has been made to synthesize this information and to develop evolution. ary models of changing Plains-Pueblo interaction over time.

Recently, however, Jim Judge and Patty Crown provided the opportunity to bring together a variety of scholars concerned with PlainsPueblo interaction. At their invitation I organized a conference on this topic involving both archaeologists and historians, Plains scholars and Pueblo scholars. The meeting was held at the Fort Burgwin Research Center of Southern Methodist University, Ranchos de Taos, New Mexico, in September 1987. The setting was quite appropriate in that Taos was the host of numerous Plains trade fairs in the seventeenth and eighteenth centuries.

Through formal papers and ample opportunity for discussion both during organized sessions and over dinner, we tackled questions concerning the variety of ways in which Plains and Pueblo populations had interacted and the processes that led to the evolution of that 
interaction over time. This volume presents the results of those papers and discussions.

We owe a great debt to Jim and Patty for proposing the conference initially and for providing gracious hospitality while we were at Fort Burgwin. The accommodations were superb and the atmosphere very comfortable. They made our stay particularly memorable. Southern Methodist University generously covered the travel costs of the participants.

After the conference we revised the papers, circulated them, and revised them a second time. In this process, numerous people provided invaluable assistance. The authors have acknowledged this help in their individual chapters. In closing, I would like to thank Marsha Schweitzer for assistance in preparing the manuscript, and Shearon Vaughn for drafting Figure I. I. I would also like to thank my husband, Bill Edwards, who has been unfailingly supportive throughout the compilation of this volume and who has provided invaluable assistance in preparing tables, proofreading, and trouble-shooting problems with the variety of word processing programs used by the authors.

KATHERINE A. SPIELMANN

May I990 
Farmers, Hunters, and Colonists 



\title{
1. Interaction Among Nonhierarchical Societies
}

\author{
KATHERINE A. SPIELMANN
}

This volume is concerned with interaction among prehistoric and historic societies in the Southwest and the southern Plains. Through the analysis of interactions in this area, our goal is to begin to elucidate processes of interaction and interdependence among nonhierarchical societies in general. However, before moving on to a discussion of interaction, I should note that the choice of anthropological terms to describe the societies we are dealing with is fairly limited (see Braun and Plog 1982, 504, for a similar complaint). The term nonhierarchical is not an ideal one, because it is based on the lack of certain attributes rather than their presence. It signifies societies in which decision making is largely consensus based and permanent positions of status and leadership based on ascription are lacking. Egalitarian is another possible term. In reality, however, purely egalitarian societies do not exist. Even in the definition of egalitarian society (Fried I968) it is acknowledged that there are status differences based on age, sex, and personal abilities. Such status differences may have profound effects on sociopolitical behavior within so-called egalitarian societies, as in the case of "big man" systems. Finally, the term tribal, as defined by Service (1962), with its implication of social networks integrated by crosscutting sodalities, may not apply to all the groups we consider, some of whom may be more accurately described as bands (see Baugh, this volume). Thus, for want of a better term, I will use nonhierarchical.

Interaction among nonhierarchical societies has come to be of increasing interest to anthropologists and archaeologists as their perceptions of these societies have changed. Originally, it was assumed that nonhierarchical societies were independent, self-sufficient 
entities (see, for example, Fried's I968 discussion of egalitarian societies). More recently, however, it has been demonstrated that nonhierarchical societies are rarely self-sufficient with regard to subsistence and other basic material resources. In fact, such societies often engage in a wide variety of exchange relations in order to gain access to various material items (see Spielmann I 986 and references therein).

The recognition that complex economic and social behaviors are possible in societies in which power is diffuse and decision making is largely consensus based has important implications for the study of the evolution of social and economic systems. Given that the majority of human existence has been in nonhierarchical contexts, it is important to understand the patterns and processes of interdependence among nonhierarchical systems. Moreover, the antecedents of chiefdom and state-level societies are to be found in the complexities present within nonhierarchical situations.

Unfortunately, the nature and degree of interdependence among nonhierarchical systems has rarely been analyzed in detail. Instead, our understanding of dependency relations involving nonhierarchical societies is derived largely from analyses of their interaction with and incorporation into state systems. For example, there has been a fair amount of research concerning hunter-gatherer articulations with contemporary states (e.g., Leacock and Lee I982; Morris I982; Eder I 987). Unfortunately, the modern world lacks situations in which nonhierarchical systems exist in the absence of influence from more complex societies. Consequently, to gain an understanding of the conditions that lead to and sustain interdependence among nonhierarchical societies, and the structures of these interdependent systems, we must focus on prehistoric and protohistoric data.

Several decades of archaeological and ethnohistorical research in the Plains and Pueblo areas provide the kinds of data necessary for studying the evolution of interactive systems. This volume builds upon these data and provides an analysis of the evolution of intersocietal relations between Southwestern and Plains populations from the late prehistoric, protohistoric, and historic periods (ca. A.D. I 200-I 870). It brings the expertise of both archaeologists and historians to bear on the topic. This kind of regional study helps elucidate (I) the processes through which small-scale societies become dependent on one another, $(2)$ the structures of these interdependent systems, and $(3)$ the evolutionary trajectories of these systems. 
In this volume we attempt to capture the dynamic nature of Plains-Pueblo interactions as environmental, demographic, social, and political conditions changed in the two areas. While each chapter provides descriptive information concerning the nature of the archaeological and/or historical record for the particular period and place under discussion, our focus is on explaining these interactions. Before proceeding with the individual analyses, however, it seems appropriate and useful to place this study in the context of both the exchange literature in archaeology and previous research on PlainsPueblo interaction. The following pages present a brief overview of recent theoretical discussions concerning intersocietal interaction and a similarly brief discussion of the history of archaeological research on Plains-Pueblo interaction.

\section{INTERACTION AMONG PREHISTORIC SOCIETIES}

Intersocietal activity can take a variety of forms, from peaceable trade to raiding and warfare. Societies may exchange marriage partners, share information, form alliances for joint ventures, and participate in rituals together. Thus, interaction is not limited to trade, let alone trade in durable objects. However, because archaeologists are usually left with only durable cultural and environmental remains for their analyses, trade has been the primary focus of archaeological research on interaction. Similarly, anthropologists concerned with intersocietal interaction in tribal societies (e.g., Sahlins 1972; Foster 1977) have argued that such interaction is largely predicated on a mutual need for one another's resources. Both these authors argue that social relations develop between societies simply to ease a potentially hostile situation, with no further ramifications. Ford (1972a), however, points out that "foreign relations" among nonhierarchical societies can take a variety of social forms.

Schortman and Urban (1 987) have recently taken archaeologists to task for their trade-oriented approach to interaction. They point out that the focus has been on how individual societies benefit economically from trade, not on the interaction itself. They suggest the necessity for a greater concern with the consequences of interaction beyond economic gains and with the potential for coevolution as societies become dependent on one another. Their points are welltaken, and in this volume we begin to provide a somewhat broader perspective on Plains-Pueblo interaction through discussions of 
intermarriage, raiding, demographic change, technological change, and the evolution of political systems. However, as the following review of research on Plains-Pueblo interaction points out, thus far the emphasis has been on identifying and explaining trade in economic goods.

Given that archaeologists concerned with interaction have focused largely on exchange, the sorts of models they have developed to explain interaction among nonhierarchical societies are economic in nature and have an ecological focus. These ecological approaches can be divided between $(\mathrm{I})$ buffering or "savings and investment" models (Befu I977), in which exchange relations provide economic security for participating societies, and $(2 \mid$ mutualism models, in which exchange is predicated upon the differential distribution of resources (Spielmann I986).

Buffering exchange is designed to deal with environmental stochasticity by averaging the risk of subsistence failure across space. An increasing exchange of craft items among nonhierarchical societies has been shown to coincide with an increasing susceptibility to environmental perturbations. The exchange of craft and ritual items is thought to establish and maintain social ties among societies that can be called upon periodically to gain access to food in times of scarcity. In addition, it is thought that durable items may be exchanged directly for food when necessary (Ford I972a, I 972b, I974; Blakeslee 1975; Braun and Plog I982; F. Plog 1984; Dean et al. I985; Braun 1986; Spielmann 1986; Douglass 1988; Gibson and Geselowitz 1988). Note, however, that environmental data analyzed by Dean et al. (1985) for the Colorado Plateaus in the Southwest indicate that the utility of spatial averaging mechanisms such as exchange can vary over time as the degree of spatial variation in climatic factors changes. When spatial variation is high, exchange can be a successful strategy, but when spatial variation in climate is low, all communities across a region experience similar climatic regimes, and exchange is not a suitable buffering strategy. In this volume, Lintz and Baugh present versions of the buffering model to explain significant increases in exchange between various prehistoric Plains and Pueblo societies.

By focusing on risk aversion, buffering models tend to minimize the role of unequally distributed resources in exchange (Riley I984; Spielmann I986). Both are probably significant in the evolution and maintenance of exchange systems among nonhierarchical societies. 
Archaeologists working with both ethnographic and archaeological data have proposed that a differential distribution of resources may be significant in the evolution of craft specialization and exchange, and in the development of the intersocietal exchange of food resources (Ford 1972a; Snow 198I; Allen 1984; Riley 1984; Arnold 1985; Spielmann 1986, I99 I; Rice 1987a, I987b).

In previous research I have developed a model of mutualistic exchange that explains the evolution of a certain degree of specialization in the production of food and other resources for the purpose of trade (Spielmann 1986, I991). Mutualism involves the exchange of material items or services to the benefit of all participants in the interaction. This benefit is translated into a higher carrying capacity for each partner in the interaction than would be possible in the absence of the relationship. Mutualism is favored when the investment in what is exchanged is low compared to the benefit received from exchange. In addition, the majority of individuals in a population must be able to participate in the interaction (Keeler 1981).

Mutualistic relations create interdependence among interacting groups because each group becomes dependent, to a greater or lesser degree, on the materials or services the other group provides. Because mutualism involves the regular exchange of critical resources between populations, the resource supply and the exchange relationship must be reliable. In human mutualisms, societies in different ecological zones may specialize in the production of complementary resources and exchange them. Thus mutualism essentially takes advantage of, and perhaps emphasizes, niche separation between populations. I will return to mutualism in the specific discussion of Plains-Pueblo interaction below. In addition, Speth and Snow elaborate further on mutualistic relations in their chapters.

In summary, two distinct ecological situations select for the evolution of intersocietal exchange among nonhierarchical societies. The first is environmental stochasticity, which results in local subsistence shortages. Exchange systems evolve to buffer these shortages through access to nonlocal food resources. These systems are predicated upon social ties that are maintained through the exchange of craft and ritual items. The second situation involves the differential distribution of resources, often subsistence resources, due to the occupation of different ecozones. Under conditions of relatively high resource abundance and predictability and relatively low costs of production, some degree of specialization in the production of comple- 
mentary resources can occur. These items are then regularly exchanged, to the mutual benefit of all interacting parties.

In concluding this section, I should note that a few archaeologists, who have found the above ecological models inadequate to explain interaction among nonhierarchical societies, have adopted some of the concepts of world systems theory. An attractive aspect of this theory is that it focuses on the total interactive system rather than on exchange transactions alone. World systems theory was developed by Immanuel Wallerstein (1974, I 979) to explain the rise of capitalistic global economies and the current state of the world. World systems are economic entities characterized by an extensive division of labor among a variety of types of units. Wallerstein defines three such units: cores, peripheries, and semiperipheries. The cores are well-developed states that exploit the labor of other units. Cores manipulate periphery systems, which are weak polities that produce low-wage, low-profit goods essential for daily use within the world system (e.g., food products). Semiperipheries are intermediate between cores and peripheries in political and economic development, and tend to stabilize world systems by being "collection points for vital skills that are often politically unpopular" (Wallerstein I974, 349-350). Wallerstein's model is dynamic in that components of the system can evolve into different types as conditions change. For example, cores can become peripheries and vice versa.

Although in his publications Wallerstein explicitly rejects the notion that precapitalist world systems existed (but see Kohl I987), some archaeologists working with prehistoric complex societies have adopted certain aspects of his model in defining and analyzing the systems with which they work (see reviews and references in Schortman and Urban 1987 and Kohl I 987). Setting aside the criticisms that have been leveled at world systems theory, both within Wallerstein's discipline of historical sociology and by these archaeologists (see Schortman and Urban 1987 and Kohl 1987), we might wonder whether such a model is at all useful in the analysis of interactions among nonhierarchical societies. It is predicated upon a hierarchical relationship between cores and peripheries, with exchange benefiting the cores to the detriment of the peripheries. This is not the sort of relationship we would expect in interactions among nonhierarchical societies. Granting this fact, there remain three aspects of the model that archaeologists working with both complex 
and nonhierarchical societies find heuristically useful: $(\mathrm{I})$ the focus on the importance of historical events as well as ecological processes (Kohl I987), (2) the focus on the totality of the interactive system rather than simply on trade (Schortman and Urban 1987 ), and $(3)$ the dynamic character of world systems theory, which ecological models tend to lack.

World systems theory has rarely been applied to the study of interactions among nonhierarchical societies. However, one of the few such applications has been to the Plains-Pueblo interactive system (Baugh 1982, 1984b). Baugh's chapter builds upon his earlier macrosystem model for Plains-Pueblo exchange, which I discuss below. Wilcox (this volume) also approaches Plains-Pueblo exchange from a world systems perspective, focusing in particular on the division of labor both within and between the Southwest and the Plains. Because he believes that protohistoric Pueblo society was hierarchically organized, he also discusses the importance of political manipulations between components of the system.

\section{PLAINS-PUEBLO EXCHANGE}

Our first documentation of Plains-Pueblo exchange comes from sixteenth-century Spanish chronicles. Their observations provide a baseline against which to view both archaeological and later historical data. A series of Spanish expeditions into New Mexico took place between 1540, when Spaniards first entered the Southwest, and I 598, when the first Spanish colony was established near San Juan Pueblo on the Rio Grande. The chroniclers of these expeditions all report the arrival of Plains nomads at certain pueblos to barter their bison meat, fat, and hides for corn, cotton blankets, and ceramics. This exchange relationship was first mentioned by Castañeda, the chronicler of Coronado's expedition to New Mexico in I 540-4I. Castañeda singled out Pecos Pueblo, mentioning that Plains groups camped outside that village in the winter to trade (Winship I 896, 274). Later, in September I58I, the Chamuscado-Rodriguez expedition reported that inhabitants of what was probably San Marcos Pueblo in the Galisteo Basin regularly traded with Plains nomads (Hammond and Rey 1966, 86). In January I 59 I the de Sosa expedition encountered "peoples from other places" who were camped in huts around Picurís Pueblo (or possibly San Juan) and who had come to 
trade (Hammond and Rey I 966, 283-284). Although the identity of these visitors is not specified, they were not identified as Pueblo Indians and could have been Plains hunter-gatherers.

The wealth of documents pertaining to the Onate expedition, which entered New Mexico in I 598 to found a colony, also contains several references to Plains-Pueblo exchange. In September I 598 an expedition onto the Plains encountered Vaqueros-Plains nomadsnear the Texas-New Mexico border who were returning to the Plains with corn obtained in trade with Picurís and Taos pueblos (Hammond and Rey 1953,400/. Witnesses in the Valverde investigation of Onate's rule in New Mexico also attested to the fact that Plains Indians traded at certain pueblos (Hammond and Rey I953, 610, 838). Finally, in the 1630 , Benavides reported in general that entire populations of Plains nomads came to trade at the pueblos (Benavides I9I6, 55-56).

The existence of prehistoric trade between Southwest and Plains populations was demonstrated early in this century through Kidder's work at Pecos Pueblo, New Mexico, and Wedel's and Holden's work on the central and southern Plains (see Fig. I.I). The excavations at Pecos, which began in I9I5, unearthed Plains-type stone and bone tools, lithic materials of Plains derivation, and fragments of bison robes (Kidder 1932; Spielmann 1983). Holden, working in the Texas Panhandle from I 929 to I 932 , excavated several sites that produced small quantities of Southwestern ceramics and obsidian (Holden 1929, I930, I931, 1932, I933; Lintz I986a and this volume). A few years later, Wedel uncovered similar Pueblo trade materials at protohistoric sites in central Kansas (Wedel 1942). Krieger's I946 treatment of the relationships between prehistoric societies of the High Plains and those of the Southwest and Southeast summarizes these early data on Plains-Pueblo trade (see also Wedel I 950).

From the I930s through the mid-I960s very few archaeologists focused their research efforts on Plains-Pueblo interaction, and those who did spread their work thinly from northeastern New Mexico and western Kansas south to the Texas-Chihuahua border (Fig. I.I). In the I93os J. Charles Kelley carried out excavations near Presidio, Texas. Through both archival and archaeological research he was able to document interaction between farming Patarabueye populations and nomadic, bison-hunting Jumano populations, a system that he considered analogous to the Plains-Pueblo exchange that had taken 


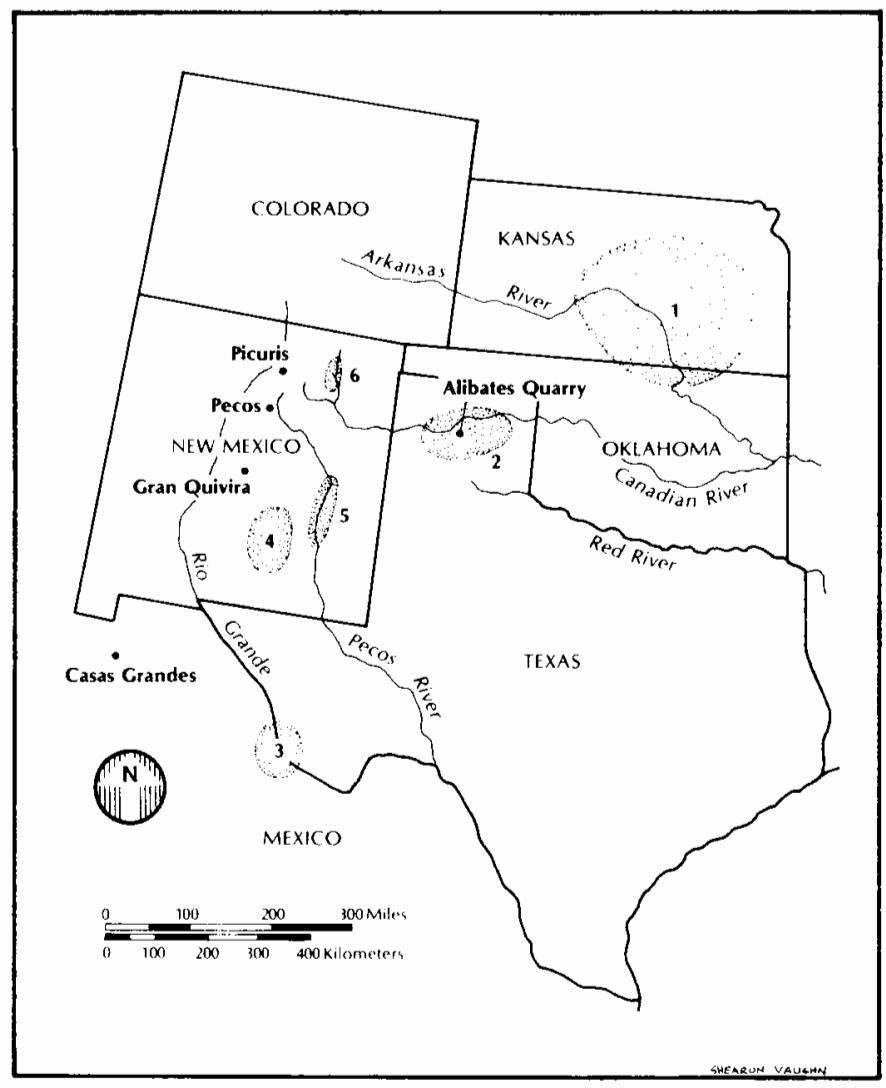

FIGURE I.I. Regional map of the Southwest and southern Plains, illustrating the locations of previous archaeological research on Plains-Pueblo interaction. Numbered areas: (I) Wedel; (2) Holden; (3) J. C. Kelley; (4) J. H. Kelley; (5) Jelinek; (6) D. Gunnerson and J. Gunnerson.

place at Pecos (J. C. Kelley I 952, I955, I986). Unfortunately, his dissertation on the subject was not published until I 986.

In the I950s Jane Holden Kelley continued Holden's work along the Plains-Pueblo border through survey and excavation in southeastern New Mexico. Her hope was to collect data pertaining to interaction between the two areas (J. H. Kelley I984, xxxvii). Her project did not obtain archaeological data suggestive of Plains contact, however, and she changed her research design to focus on the evolution of farming populations in this area. 
Moving eastward, we come to Jelinek's work in the middle Pecos valley between Fort Sumner and Roswell, New Mexico, during the I950s and I $960 \mathrm{os}$. He, too, had planned to deal with contacts between the Southwest and the Plains (Jelinek 1967, I, I64). However, the data he collected documented instead an in situ transition from farming to hunting rather than an interaction between farming and hunting populations.

Finally, on the northeastern fringe of the Southwest, the Gunnersons have carried out decades of research on historic Plains sites, focusing in particular on Athapaskan materials both on the Plains of western Kansas and eastern New Mexico, and at Pecos Pueblo (D. Gunnerson 1956; J. Gunnerson 1959, 1960, 1968, 1969; Gunnerson and Gunnerson 1970).

During these decades of research there was little attempt at analyzing the nature and purpose of the interactions that had resulted in the trading of materials between Plains and Pueblo societies. Krieger went so far as to postulate that the relations "transcended that of trade alone" (I946, 268) but did not elaborate on this statement. As others have pointed out, diffusion was the dominant explanatory model of the time (Baugh 1982; Schortman and Urban I987). It was acceptable simply to document patterns of trait distribution without explaining why diffusion had occurred.

In the early 1980s, several researchers, including Baugh, Spielmann, and Wilcox, independently began to focus specifically on the interaction between protohistoric Plains and Southwestern societies. Each of these archaeologists developed a unique explanatory model for the evolution of Plains-Pueblo interaction; my model is derived from evolutionary ecology, while those of Baugh and Wilcox take a world systems approach. The remainder of this section provides a brief overview of these formulations as background for the subsequent chapters in this volume.

My concern has been to explain the evolution and maintenance of interaction between protohistoric (A.D. I450-I700) Pueblo populations in central New Mexico (at Pecos, Gran Quivira, Taos, Picurís, and the Galisteo pueblos) and southern Plains hunter-gatherers. I have focused on the economic and nutritional benefits of exchange. I have assumed that the annual exchange of foods between these two groups (documented by the first Spaniards to enter the Southwest) developed in prehistory and that the exchange of complementary food resources, corn for meat, was central to the evolution of the 
exchange system. Because this system appears to have been mutualistic, I have developed and partially tested a model of the mutualistic exchange of meat for corn between Plains hunter-gatherers and Pueblo horticulturalists (Spielmann I99I). The two aspects of this model that have been tested are (I) the reliability of corn production in the Pueblo area, and $(2)$ the relative costs and benefits of $(a)$ Pueblo groups obtaining meat protein through hunting or through trade, and (b) Plains groups obtaining calories through hunting or through trade.

Spielmann (I99I) contains a detailed discussion of the computer simulation of the Plains-Pueblo exchange system to evaluate its costs and benefits. In brief, the results of this study indicate that a Pueblo village such as Pecos was capable of producing enough surplus corn to trade with Plains groups annually and yet maintain adequate corn in storage against years of poor production. Further, trade for this corn is a less costly means for Plains hunter-gatherers to obtain calories than is year-round hunting, in terms of both procurement costs and risk costs (see also Speth and Spielmann 1983). However, trade is not a least-cost strategy for Pueblo farmers to obtain meat unless local herds of mule deer and antelope have been overhunted. Recent archaeological data from Gran Quivira Pueblo, New Mexico, indicate that trade with Plains groups for bison does appear to have developed because local antelope herds were becoming depleted (Spielmann 1988). Speth considers overhunting in the Pueblo area further in his chapter.

Baugh (1982, r984b) has concentrated less on the economics of Plains-Pueblo exchange than on the structure and dynamics of the exchange system. He has modified Wallerstein's world systems model to fit interactions among less complex societies, and he terms his model the Southern Plains Macrosystem. As in Wallerstein's model, this system has three components: cores, peripheries, and semiperipheries. The cores are the Pueblo farming villages in central New Mexico that provide horticultural and manufactured goods to periphery populations of Plains nomadic hunter-gatherers. Alliances, trade partnerships, and intermarriage create fairly strong links between core and periphery populations. The semiperiphery is composed of part-time horticultural populations in western Oklahoma and central Kansas who occasionally trade with groups to their west and east, including the Pueblos. Alliances between semiperiphery populations and cores, however, are weak. 
Baugh and I concur in our emphasis on the interdependence created between Plains and Pueblo populations by the exchange of complementary staple resources from different ecozones, but we differ in our interpretation of the degree of this interdependence. Baugh argues that the periphery is less dependent on the core than the core is on the periphery, while I maintain that the hunter-gatherers of his periphery are dependent on traded horticultural products. In addition, rather than giving the farming populations of Kansas and Oklahoma a separate structural position in the Plains-Pueblo system, I consider them to be analogous structurally to the New Mexican Pueblos. I expect that all these farming populations engaged in mutualistic exchange with Plains nomads. I doubt that protohistoric Plains and Southwestern horticultural populations regularly exchanged directly with one another.

Wilcox (I98Ia, I98Ib, I984) views Plains-Pueblo exchange from the Southwest side of the system and considers it in the context of an interethnic division of labor that appears to have evolved during the protohistoric period in the Rio Grande Pueblo area. As he elaborates in this volume, Wilcox believes that Rio Grande Pueblos evolved into a series of ethnically distinct polities that interacted with one another through exchange, alliance, and warfare. Specialization in the production of craft items (see also Snow I98I) may have fueled this exchange system. Interaction with Plains nomads is, then, a facet of this division of labor. Further, Wilcox argues that the evolution of this panregional system was in response to the fall of the Casas Grandes trading system and the need for Southwestern populations to tap another source of economic input-in this case, the Plains.

Like Baugh, Wilcox argues that Plains Caddoan and Wichita farming populations interacted directly with Pueblo villagers and that the Plains-Pueblo system was highly integrated politically as well as economically. In contrast, I question whether the economic division of labor that characterizes Plains-Pueblo relations carries with it this degree of sociopolitical coherence. While there probably were fairly strong alliances between particular hunter-gatherers and particular farming villages (possibly maintained through the inheritance of trade partnerships [Ford I972a]), I am not convinced that Pueblo, Caddoan, and Wichita agriculturalists monitored and made decisions based upon one another's exchange activities. 
Baugh, Wilcox, and I have focused largely on the protohistoric period, from about A.D. I 450 to I 700 . However, Plains-Pueblo interaction did not begin or end with the farmer-hunter-gatherer trade of the fifteenth and sixteenth centuries. It is well known that Pueblo ceramics appear at Plains late prehistoric (A.D. I 200-I 450) sites that predate this era, and the trade fairs, alliances, and battles involving Plains and Pueblo groups in the historic period have been well documented. The dynamic nature of Plains-Pueblo relations can only be appreciated and understood by incorporating the information from all three periods into one coherent whole. While we do not fully accomplish this goal in the present volume, we do elaborate on some of the developments and processes that must be understood to achieve a synthesis of Plains-Pueblo interaction. In the future it will be stimulating to focus on coevolutionary factors, such as the influence of Plains-Pueblo exchange on the evolution of social and political organization in the participating societies (Wilcox 1984), and the evolution and implications of power differences among the interacting groups in the historic period (Befu I977; Spielmann 1986).

\section{SUMMARY OF THE CHAPTERS}

The following three chapters elaborate upon mutualistic PlainsPueblo interaction through discussions of $(\mathrm{I})$ factors that sustained and affected Plains-Pueblo exchange (Speth), (2) aspects of competition and parasitism that were components of this interaction (Spielmann), and (3) the importance of exchanged goods other than food to the adaptations of Plains nomads (Habicht-Mauche).

The five remaining chapters place the protohistoric system in the broader context of Southwest and Plains intersocietal relations. Three chapters, one focusing on the Southwest (Snow) and the others on the southern Plains (Lintz, Baugh), analyze intersocietal relations between A.D. I 200 and I 450 . In each case, pre-I 450 relations appear to have been primarily among farming groups rather than between farming and hunting populations. Moreover, increasing interaction both within and between the Southwest and the Plains appears to coincide with an increasing vulnerability of horticultural crops to drought or shorter growing seasons. Thus the Plains-Pueblo interaction of the thirteenth and fourteenth centuries may have buffered local shortfalls in subsistence resources. For example, both Lintz and 
Baugh argue that this trade was but one of a series of strategies to acquire subsistence resources beyond locally produced horticultural products on the southern Plains. Hunting and gathering increased along with trade, indicating that southern Plains economies were becoming more generalized.

Snow focuses on farming populations who lived at different altitudes at the eastern border of the Southwest. He argues that shortfalls in horticultural products at high altitudes may have been recurrent enough that exchange with farmers at lower altitudes became regular and in essence mutualistic. Meat and hides may have moved from higher-altitude farmers in return for seed corn from lower-altitude farmers.

The intent of Wilcox's chapter is to place the Plains-Pueblo interactive system in the context of other prehistoric interactive systems operating in the Southwest, such as those based at Casas Grandes and within the Rio Grande valley. Building upon his earlier interethnic division-of-labor model, Wilcox begins by marshaling further data to argue for the existence of ethnic alliances, or polities, in the protohistoric Southwest. He continues with a discussion of the dynamics and structure of the Plains-Pueblo exchange system and the significance of these polities to its integration.

The final chapter, by Levine, focuses on the historic participation of Spanish colonists in trade with Plains groups /see also Baugh, this volumel. Levine focuses on the comanchero trade between Hispanic New Mexicans and Plains Comanche during the eighteenth and nineteenth centuries. She demonstrates that this exchange served very different purposes for each society. Comanche "big men" enhanced their prestige by acquiring European goods through trade with New Mexicans. In contrast, trade with the Comanche was part of a broadbased subsistence economy for the comancheros. The comancheros' situation does not appear to have been very different from that of the Plains farming populations in the thirteenth and fourteenth centuries, whose generalized subsistence strategy embraced farming, hunting, gathering, and trading.

\section{CONCLUDING COMMENTS}

Taken together, the chapters in this volume document a process of increasing interdependence between Southwestern and Plains populations over time. Initially, village farmers in both areas appear to 
have interacted periodically, perhaps to alleviate shortfalls in corn production. With the arrival of hunter-gatherer populations on the southern Plains and the aggregation of Pueblo populations in the Rio Grande area (see Speth, this volume), mutualistic exchange developed in the fifteenth century, and exchanged food products became important components of the diets of both Plains nomads and Pueblo villagers. Concurrently, the Rio Grande area became more economically specialized, resulting in a panregional system of complementary production and exchange.

The evolution of Plains-Pueblo interaction is the result of a dynamic interplay between ecological and historical factors. It is predicated upon consistent ecological differences, primarily differential horticultural and faunal production, between the two areas. The Rio Grande area, at elevations below 7,000 feet, allowed a higher level of corn production than did the river systems of the southern High Plains. In contrast, the Plains provided dense concentrations of a major source of meat protein - the bison. Human population densities also differed consistently between the two areas during the period considered here, with the Rio Grande area being higher in density than the southern Plains.

These ecological characteristics are not determinants of the exchange systems we document in this volume, however. Instead, it is the relationship between these characteristics and other variables that led to the evolution of Plains-Pueblo interaction. Those variables include ( $\mathrm{I}$ ) climate, which became drier over time on the southern Plains, (2) commodities desired by different ethnic groups, (3) differential power among ethnic groups, and (4) population size and density. Population changed independently of local environmental factors in both regions due to in-migration during this period: late prehistoric Anasazi residents of the Colorado Plateau moved into the Rio Grande valley; protohistoric Athapaskans moved south from the central Plains into the Texas Panhandle area; Plains Caddoans may have migrated out of the southern Plains area prehistorically; and the Comanche entered the Plains in the historic period. Other historic factors affecting exchange include the arrival of the horse, which aided the mobility of Plains nomads such as the Comanche and significantly changed their adaptations, and Spanish colonization of New Mexico, which substantially affected indigenous Pueblo adaptations, including access to Plains products /see Spielmann r989a; Baugh, this volume). 
Buffering strategies appear to have developed largely in response to climatic stress, due either to increasing drought or the shorter growing season at higher elevations in the Southwest. The transition from a buffering to a mutualistic relationship involved both increasing population density in the Rio Grande area and the presence of a new group of specialized bison hunters on the southern Plains. This specialization probably evolved first in the northern Plains: I expect that the Athapaskan movement southward was facilitated by the development of mutualistic relations with farming populations first on the upper Missouri and later on the Arkansas River.

With the arrival of the Spaniards and their participation in trade with Plains nomads, interethnic relations shifted dramatically. In particular, the Plains hunter-gatherer demand for imported European items (e.g., horses and guns) outstripped the supply available through trade. As Plains military capabilities became greater, raiding joined trading as a means of acquiring Southwestern goods. Moreover, these trade items functioned in both the economic and social spheres of historic Plains cultural systems. Most historic Southwesterners, Hispanic and Pueblo alike, continued to depend on trade with Plains hunters to acquire a variety of animal products for subsistence purposes in much the same fashion as prehistoric Pueblo populations had. New Mexican governors, however, sought to monopolize the exchange as much as possible in order to profit from selling Plains commodities in Mexico (Spielmann 1989a; Levine, this volume).

Hispanic and Comanche populations in the Southwest and the Plains were more powerful than the indigenous groups and were able to manipulate the exchange system to their advantage. Spanish officials, empowered by a state-level system, were able to co-opt the Plains-Pueblo exchange for their own purposes. Comanche bands, with better access than the Apache to the horse and gun (Secoy 19531, managed to drive the prehistoric trade partners of the Pueblos off the Plains entirely.

Significantly, the balance of power that existed in the prehistoric Plains-Pueblo exchange system persisted in the historic system. The Spaniards were never able to conquer the Comanche. Nor did the Comanche come to control the sedentary farmers. Presumably, high mobility and multiple alliances with Pueblo and Hispanic populations maintained the relative independence of Comanche groups. Much higher population densities, state-organized militias, and better access to weaponry would have been important in maintaining 
Southwestern autonomy. Consequently, we do not witness the absorption of one society by another that tends to characterize the present-day farmer-hunter-gatherer interactive systems mentioned at the beginning of this chapter.

The following chapters, then, provide insights into both the types of intersocietal relations that existed among prehistoric nonhierarchical societies and the nature of change when more complex societies enter an interactive system. We hope that future archaeological and ethnohistorical studies in different regions will add to what we have begun here. Ultimately we should be able to construct a coherent, dynamic model of interaction among nonhierarchical societies. 


\title{
2. Some Unexplored Aspects of Mutualistic Plains-Pueblo Food Exchange
}

\author{
JOHN D. SPETH
}

Studies of Plains-Pueblo interaction and food exchange in the American Southwest are based largely on the descriptive accounts of early Spanish military expeditions and missionaries who explored and colonized the region in the sixteenth, seventeenth, and eighteenth centuries (see discussion and references in Briggs I968; Spielmann 1982, I26-I35; Ford 1983). These documents are invaluable, providing most of what we presently know about the nature, timing, and importance of food exchange between Plains bison hunters and Pueblo corn farmers.

Archaeology, though limited largely to the consideration of nonperishable classes of material, has also contributed useful insights, suggesting that similar patterns of exchange may already have been in place prior to the Spanish entrada. Archaeological data show that these exchanges probably varied through time in frequency and/or intensity, and perhaps also in directional focus (Collins I97 I; Snow I981; Spielmann I982; J. C. Kelley I 986). But until recently, both the ethnohistorical and the archaeological approaches have been largely descriptive in their treatment of the phenomenon. Neither has adequately grappled with Plains-Pueblo food exchange as a process, explaining why it occurs at all and why it might vary both spatially and temporally in frequency and intensity.

In fact, with few exceptions, archaeologists and ethnohistorians have simply assumed that Plains-Pueblo food exchange arose as a buffering mechanism to cope with local or regional shortfalls in crop yields or hunting returns, and that such exchange varied in intensity largely in response to the degree of need on the part of the recipients 
and the ability or willingness to provide on the part of the donors. While there certainly are many documented ethnographic examples of buffering, Spielmann's recent work on Plains-Pueblo exchange (1982, I986, and this volume), stimulated in part by the work of Bates and Lees (1977) on Middle Eastern pastoralist-state interaction, has shown that food exchanges are also very likely to occur under conditions of comparative resource abundance and predictability. In fact, this form of exchange, analogous to what evolutionary ecologists refer to as mutualism, develops and persists precisely because conditions are sufficiently favorable and stable to make the probability of continuing exchanges in the future highly likely (e.g., Goh I979; Addicott 1984).

Spielmann's work is an important step forward in our understanding of Plains-Pueblo food exchange. Above all, it demonstrates that intergroup food exchange is a complex, multifaceted phenomenon that can involve much more than just a simple buffering response when subsistence returns fall short of needs. My purpose here is to build on the base established by Spielmann, zeroing in on four aspects of mutualistic food exchange that I believe are important components of the process and that have not yet been considered explicitly in the Plains-Pueblo context. The four aspects that I have chosen are the following: $(\mathrm{I})$ the impact on mutualistic food exchange of hypergyny-the outflow by marriage of hunter-gatherer women into Pueblo communities; $\{2 \mid$ the annual timing of mutualistic food exchange between farmers and foragers stemming from the nonsynchroneity of their seasonal or interannual hunger periods; $(3)$ changing strategies of protein acquisition by farming communities in response to increasing horticultural commitment, greater village permanence, and local large-game depletion; and (4) nutritional constraints that push hunter-gatherers to exchange protein for carbohydrates with farmers.

The discussion that follows is entirely exploratory and preliminary in nature. I have no illusions that the four aspects of the issue I have singled out for consideration here will, by themselves, provide a coherent theory or model of mutualistic Plains-Pueblo food exchange. What I do hope this chapter will provide is a basis for more in-depth discussion among Southwestern and Plains archaeologists, ethnologists, and ethnohistorians of some of the many facets of hunter-gatherer-horticulturalist mutualistic interaction that have 
not yet been explicitly considered. I also hope that some of the factors discussed here will contribute to a more general understanding of forager-farmer interaction in other contexts as well.

\section{HYPERGYNY}

Recent studies of the mating strategies of hunter-gatherers have noted the widespread (though by no means universal) tendency for hunter-gatherer women to marry men in the villages with which their group interacts, while village women almost never marry forager men (R. Bailey 1985, I988). In other words, women of lower socioeconomic status commonly move up the status hierarchy, marrying less fortunate men in higher social categories who must marry down to find a mate. This phenomenon, known as hypergyny (see Dickemann I 979|, has been most clearly documented among the Efe Pygmies of eastern Zaire, but it is alluded to in the ethnographic accounts of many other hunter-gatherer groups (e.g., Blackburn I982; R. Bailey I988; Ndagala I 988, 71; Woodburn I 988, 39, 43!.

In general, hypergynous marriage relationships between huntergatherers and neighboring horticulturalists occur in situations in which the two systems interact on an asymmetrical basis, in which the foragers are viewed by both parties in the interaction as culturally and economically inferior (see discussion in Woodburn 1988). The source of the asymmetry in Pygmy-Bantu (or Pygmy-Sudanic) relationships may stem from the high degree of economic dependence of the hunter-gatherers on the farmers' carbohydrates. Although still controversial, there is growing evidence that the Pygmies may not have been able to survive in the Ituri Forest, at least not as we see them today, before they had reliable access to farmers' produce. For up to five months each year, the wild carbohydrate resources in the forest may have been inadequate to support a purely foraging economy (Hart and Hart I986; R. Bailey et al. I989; see also Hutterer 1982, I35-137; Headland and Reid 1989; Piperno I989). The Ituri farmers, on the other hand, are not as closely dependent on the forest products provided by the Pygmies and commonly engage in trapping and other procurement activities to obtain animal protein (Robert C. Bailey, personal communication, I989).

This upward, or hypergynous, marriage pattern among the Pygmies has an interesting impact on their economy (R. Bailey r988). The Pygmies provide Sudanic- or Bantu-speaking farmers with labor 
and meat, and in return receive carbohydrates, trade goods, and various services. Over I 3 percent of the eligible Pygmy women are lost to village men through hypergyny, and 37 percent of Efe Pygmy men of marriageable age are unmarried (R. Bailey 1985,217 ). This places Pygmy males in competition with each other for mates. One way for these unwed men to make themselves more economically attractive as marriage partners is to devote more time to hunting and gathering activities specifically aimed at acquiring meat, honey, and other forest products for exchange with the horticulturalists. The impact of this competition on the Pygmy economy is to foster greater economic specialization-particularly focused on hunting-than would occur if hypergynous marriages did not take place.

A similar example is provided by the Okiek, a Dorobo foraging group in the central highland forests of Kenya (Blackburn 1982). For the Okiek, loss of eligible females through marriage to Maasai pastoralists fosters economic specialization on the part of the forager males, this time in the overproduction of honey rather than meat for exchange/the Maasai despise the meat of wild animals but place high value on honey). According to Blackburn (I 982, 288-289), "to a great extent, Okiek adaptation to a foraging way of life derives from their desire to acquire and use honey. This is true despite the fact that honey contributes no more than I 5 per cent to the Okiek diet."

Turning now to the Plains-Pueblo case, I have not succeeded in finding quantitative data in the published ethnohistorical literature on the frequency of hypergynous marriage in the region. Admittedly, however, my search to date has been anything but systematic, and I have made no attempt to go directly to unpublished archival records. Reliable data on this phenomenon may prove to be exceedingly difficult to cull from the early Spanish documents. As pointed out by David Brugge (personal communication, I987; see also Brugge r 965 , I 985 l, the patterns of marriage between Southwestern foragers and farmers were altered dramatically by the Spanish presence. For example, the influx of nomadic peoples into the Spanish domain following the conquest may have been the product of Spanish slaveraiding or of power imbalances between different nomadic populations that forced members of weaker groups to seek protection from the Spaniards or from the Pueblos. The Spanish presence also triggered population movements in the other direction. The Pueblos were under much more direct and effective control than the nomadic populations, and to escape Spanish dominion, fugitives and refugees 
from the Pueblos often sought protection among nomadic groups. Others may have been taken as captives by Plains groups.

Given the tremendous social and political upheavals precipitated directly or indirectly by the Spaniards, Plains-Pueblo relationships may have been so totally disrupted and altered that pre-Hispanic marriage patterns may be difficult to discern in the archival records. Despite these difficulties, however, Brugge (personal communication, I987) feels that a systematic search of the early church marriage records might still prove rewarding. Given the widespread occurrence of hypergyny among ethnographically documented huntergatherer populations elsewhere, I would be very surprised if such a pattern were not present in the Southwest, particularly in the prehorse period before Plains groups achieved clear military superiority over the eastern Pueblos. Hypergyny may even prove to be detectable in the archaeological record, revealed through stable isotope analysis of prehistoric skeletal remains by the presence in Pueblo sites of females who display the effects of "anomalous" nonlocal diets (Katzenberg and Kelley n.d.).

If hypergyny did occur in the Plains-Pueblo context, its impact may have been similar to the Pygmy and Okiek examples. Plains males may have found themselves competing with each other for mates. To improve their economic status and thereby enhance their marriageability, they may have devoted more time and effort to bison hunting than would be expected in the absence of hypergyny. This would have fostered increasing economic specialization and encouraged or reinforced mutualistic exchange relationships between the two systems. This suggestion, of course, remains entirely hypothetical at present, but it offers an interesting and potentially rewarding line of inquiry for the future.

\section{NONSYNCHRONOUS HUNGER SEASONS}

For hunter-gatherers in temperate and more northerly latitudes, winter and spring may pose the greatest threat of food shortage and even starvation /see discussion and references in Hayden I 98 I, 4I 2413; Speth and Spielmann I983; Speth I987a, I990). Stored resources may be exhausted by the end of winter, forcing the foragers to rely heavily on hunted foods, including prey that is severely fat-depleted and therefore of limited nutritional worth (Speth 1983 , 1987a, 1987b, I989, I990; Speth and Spielmann I983). The foragers' ability to dis- 
perse into small groups and move long distances to take advantage of a variety of resources may be critical to assuring their survival through the spring.

Temperate-latitude farmers may face a somewhat different stress regime. As in the case of foragers, winter may tax their stored food supplies, but because they live in more permanent communities and rely on foods that have long shelf-lives, particularly grains such as maize (Soffer 1989), farmers are better equipped to store larger quantities of food for longer periods. For example, ethnohistorical records from the Southwest indicate that many of the larger pueblos attempted to store up to a three-year surplus of corn when possible (Spielmann 1982; Burns 1983). A reserve of this magnitude is almost unknown among mobile foraging populations. Thus, while winter and spring may have been difficult times for farmers during particularly bad years, they probably did not face food shortages each winter and spring, as did the hunters and gatherers.

On the other hand, numerous ethnographic studies suggest that during times when stored crops from previous years are not available, farmers are more likely to face caloric deficits during the period between planting and harvesting (Dugdale and Payne 1987), that is, during the summer and early fall in the temperate latitudes of the Northern Hemisphere. Beginning in the spring and continuing through the summer, farmers must subsist on ever-dwindling supplies of stored foods, supplementing their diet with locally available hunted and gathered wild foods (and prematurely harvesting crops such as green corn). At the same time, they must increase their labor expenditures to prepare fields for planting, clean and repair irrigation canals, weed gardens and protect them from rodent and insect predation, and harvest the crops and prepare them for storage. Moreover, at this time of the annual cycle, farmers generally lack the mobility options open to hunter-gatherers, making it difficult or impossible for them to exploit wild plant or animal resources remote from their village.

While the frequency and magnitude of resource stress confronting farmers during the preharvest season undoubtedly depends on a multitude of factors (for example, climatic and environmental conditions, local and regional populations, and the range and cost of available coping strategies), this discussion nevertheless suggests that Southwestern farmers, like their counterparts in other parts of the world, may have experienced fewer seasons of hunger than did forag- 
ers in the region, but when food shortages did develop, they probably occurred somewhat later in the year (for more detailed discussions of coping strategies available to farmers in times of stress in the Southwest and elsewhere, see Ford 1968; Colson 1979; Minnis 1985; Speth and Scott 1985b, 1989; Wetterstrom 1986; and Snow, this volume).

The potential lack of synchroneity in the hunger seasons of the two systems has interesting implications for the issue of Plains-Pueblo food exchange. First, during the spring - the foragers' annual hunger season-the farmers may have had an excess of carbohydrates in storage, and this is precisely the resource needed by the nomads. At the same time, the nomads may have had an excess of lean meat that was of limited nutritional value to them (see below; see also Speth and Spielmann 1983; Speth I987a, I 987b, 1989, I990) but that may have been in short supply in the farmers' starchy diet. Thus, during the winter and spring, the needs of the two systems, and the foods they had available for exchange, were complementary and may well have favored mutualistic exchange relationships. Hides, which are generally in their best condition in late fall and winter, probably also entered into these transactions.

Somewhat later in the year, however, the situation may have been quite different. During the summer, the hunter-gatherers very likely would be emerging from their spring low point, and their calorie deficit would be diminishing. On the other hand, if the year proved to be a bad one for farmers, they might just be entering their most stressful period and would increasingly be in need of calories rather than protein. At this point the two systems would be far less complementary, and interaction might be minimal or even competitive /see Spielmann, this volume). While bison condition generally improves throughout the summer, the peak availability of animal fat would not come until the fall, when the cows are in their best condition. Hence, during the farmers' preharvest summer hunger period, Plains groups may have had limited amounts of calorically rich food to exchange with them and little incentive to do so.

While speculative, these arguments suggest that food exchange was most likely to occur in the late fall, winter, or early spring (i.e., after the harvest and before planting), when the farmers are most likely to have had a surplus of starchy calories and to have needed high-quality protein, and the nomads were most likely to have had excess protein but to need carbohydrates (exchange may have begun by early fall if Pueblo farmers were harvesting green corn; see Snow, 
this volume). By summer, particularly in a bad year for the farmers, Pueblo needs may have switched to calories rather than protein, and at that point the two systems would have had considerably less to offer each other.

These arguments, while exceedingly tentative, lead to conclusions that closely match observations made by the early Spanish expeditions to Pecos-nomadic groups, perhaps Apaches, wintered at the pueblo, exchanging products of the hunt for corn (see discussion in Spielmann I982, I26-I35). What the documents leave unclear is whether regular food exchanges also occurred at other times of the year, particularly during the preharvest period. The arguments presented here suggest that such exchanges did not occur, at least not on a large scale.

\section{INCREASING HORTICULTURAL COMMITMENT,} AGGREGATION, AND LARGE-GAME DEPLETION

Elsewhere, Susan Scott and I have discussed a common, though by no means universal, trend through time in late prehistoric Southwestern and southern Plains horticultural village sequences toward increasing relative emphasis on larger mammals, especially ungulates such as antelope, deer, mountain sheep, and bison (Speth and Scott 1985 b, 1989/. This trend is clearly visible in Chaco Canyon, for example, where lagomorphs were gradually supplanted in the subsistence remains by antelope and deer as human population levels in the region climbed toward their peak in the I Ioos (Akins I982). A similar trend can be seen throughout most of the southern Plains, where deer and rabbits gave way to bison in the 1200 s as the mixed economies of the Plains Woodland period were transformed into the more heavily horticultural Plains Village pattern (see, e.g., Jelinek 1967; Collins 197 I; Lehmer 1971; Dillehay 1974; Lynott 1980; Dallman 1983,60; Wedel 1983; Fawcett 1987). This certainly was not the first time that bison were exploited by hunters in the southern Plains. Bison are relatively common in archaeological sites during two earlier periods, the first during the latter part of the Paleo-Indian period, the second during the post-Altithermal portion of the Archaic (ca. 2500 B.C. to A.D. 500). During the last few centuries preceding European contact, however, bison remains in southern Plains archaeological sites-both residential sites and kills-increase to quantities unparalleled in earlier times (see Dillehay I974; Fawcett 1987). 
These late prehistoric and protohistoric faunal trends run counter to the view commonly held by archaeologists, and often bolstered by arguments from optimal foraging theory, that increasing horticultural commitment and residential permanence lead to the depletion of preferred large-game species and hence to greater reliance on a broad spectrum of smaller, less desirable species, often taken in nearby gardens (Linares 1976; Winterhalder and Smith I 98I; Nelson and Cordell 1982; Neusius 1984).

To understand the seemingly counterintuitive faunal trends seen at Chaco and throughout the Plains, Scott and I turned for insights to the ethnographic literature on the hunting strategies of smallscale horticulturalists. The ethnographic cases indicate that the shift toward greater reliance on large species (for hides as well as food) is a common socioeconomic response that accompanies the aggregation of populations into more residentially stable and more horticulturally based communities (see, e.g., Hames I980; Vickers r980). Contrary to our initial expectations, it is often the horticulturalists, not the foragers, who focus most heavily on large mammals (Speth and Scott 1989; see also Jones I984).

As foragers begin to increase their reliance on cultivated starchy crops, their need for efficient sources of high-quality protein increases. Increasing horticultural commitment also introduces new time and labor constraints that force them to reschedule their hunting activities to more restricted periods of the year (see discussion in Hames and Vickers 1983 and Dufour 1985). As the emerging farming communities become larger and more residentially stable, they also begin to degrade their immediate environs and deplete locally available game, forcing the hunters to travel farther to more productive hunting areas. At the same time, greater reliance on horticulture may improve the reliability of their principal calorie sources, permitting the hunters to indulge in higher-risk procurement strategies such as large-mammal hunting. Where fish are not a viable alternative resource, these factors favor, at least initially, the taking of selectively greater proportions of larger, higher-yield prey. This shift toward larger game rather than toward a broader spectrum of less optimal smaller prey types is in no way at variance with the expectations of optimal foraging theory but instead falls within a special domain of the theory known as central place foraging (Orians and Pearson 1979|. Basically, a central place forager is a generalist close to home but a specialist far from home (Pulliam 1981, 67). 
Resource depletion around a village may also favor increased reliance on communal techniques for hunting both small and large species (Speth and Scott 1989). Again, contrary to our initial expectations, the ethnographic literature suggests that both foragers and small-scale horticulturalists use communal hunting techniques primarily in special social or ceremonial contexts, such as during initiation rites and intervillage feasting, and only incorporate them into routine daily subsistence practices when resources close to the village become severely depleted or when the group becomes heavily involved in procurement for exchange or commercial transactions (see Hayden 198I, 37 I; Bailey and Aunger 1989).

As long as regional population densities remain comparatively low, the fission of larger villages is possible, and groups are able to relocate their settlements relatively frequently, or as long as competition among adjacent groups maintains suitable buffer zones in which larger prey species are subject to reduced hunting pressure, an emphasis on large species may persist. But at some as yet unknown threshold of resource depletion brought about by reduced community mobility or increased horticultural activity, or by a change in the political or demographic environment, other strategies may come to be favored for maintaining adequate protein intakes (Hames and Vickers 1983; Speth and Scott I989). One option, which usually entails an increase in labor input, is to alter one's cropping patterns and crop mix to include plants with higher protein yields (e.g., the cultivation of multiple varieties of beans by the Hohokam and other prehistoric groups in the Southwest; see Ford I98 I and references therein). Another option is to shift to greater dependence on domesticated sources of animal protein (e.g., perhaps the turkey in late prehistoric sites in the middle Rio Grande valley; see Schorger 1966 and Breitburg I988). Another option, restricted to communities in suitable riverine habitats, is to increase one's reliance on fish (an option not widely documented in the prehistoric Southwest, though in some areas this may be an artifact of preservation or site sampling techniques). Finally, the strategy of particular interest to us here is to engage in mutualistic exchange for meat with other populations that have greater access to large game.

The scenario just outlined leads to an interesting conclusion. Pueblo farmers may not have entered into mutualistic exchange relationships with Plains bison hunters until the level of horticultural commitment, village permanence, and local resource depletion had 
crossed some critical threshold, substantially increasing their degree of dependence on large mammals that could only be procured in distant hunting zones. Along the eastern margins of the Southwest, this threshold may not have been reached until the period of aggregation in the I 300 S or I 400S, which was marked by the emergence of major settlements like Pecos, Gran Quivira, Abo, and Quarai (see discussions by Lintz and Snow, this volume). In hindsight, it is perhaps not surprising that Curry Holden and Jane Holden Kelley, after excavating several pre-aggregation-period sites in the Sierra Blanca-Sacramento region of southeastern New Mexico, failed to find any unambiguous evidence of Plains-Pueblo "interaction" (J. H. Kelley 1984, xxxvii). My own work east of the Sacramentos in the Roswell area at the thirteenth- and fourteenth-century Henderson Pueblo likewise failed to find any concrete evidence of regular exchange with Plains groups even though the fauna from this fifty- to seventy-room village is overwhelmingly dominated by bison (Rocek and Speth 1986; Speth and Rautman n.d.). It is very likely, though still speculative, that the Henderson villagers hunted their own bison, obtaining little if any meat through exchange with nomadic Plains groups. Further work, probably involving computer simulation, will be needed to pinpoint the actual threshold conditions at which large species would become sufficiently important to Pueblo horticulturalists to have favored the emergence of mutualistic interdependencies with Plains nomads.

\section{NUTRITIONAL CONSTRAINTS}

In exploring the ethnographic and ethnohistorical literature, Katherine Spielmann and I some years ago noted the widespread tendency of foragers selectively to seek out fatty meat and marrow (Speth and Spielmann I983; Speth 1983, I987a, I987b, I989, I990; see also Hayden $198 \mathrm{I}$ and Jochim $198 \mathrm{I}$ ). There are many reasons why foragers show such a decided preference for lipids. First, fatty foods taste good, and fat conveys a feeling of satiety when one has eaten. Moreover, fat is a highly concentrated source of energy, supplying more than twice the calories per gram than either carbohydrates or protein, and fat is more efficiently metabolized than protein (Guthrie I975; Mead et al. 1986; Speth I987a). Finally, lipids are a critical source of fat-soluble vitamins and essential fatty acids. While forag- 
ers may be unaware of the nutritional importance of these micronutrients, they nonetheless experience a feeling of health and wellbeing when they consume sufficient quantities of lipids (see, e.g., Stefansson 1944, I956).

There is, however, another extremely important reason why fat (and carbohydrates) may become more critical to foragers than protein, especially during times of resource stress. Although there has been only limited research on the subject, there appears to be an upper limit to the total amount of protein (both plant and animal) that an individual can safely consume on a sustained basis without serious health consequences. This limit-the total number of grams of protein per unit of lean body mass that the body can safely handle-is about $300 \mathrm{~g}$ or roughly so percent of one's normal total daily caloric intake. Prolonged protein intakes above this threshold may exceed the rate at which the liver can metabolize amino acids and the body can synthesize and excrete urea, leading to serious impairment of liver and kidney function, a variety of other disorders, and ultimately even death (see, e.g., Hegsted and Linkswiler I $98 \mathrm{I}$; Miller and Mitchell I982, I I5-I I6; McGilvery I983; Whitney and Hamilton 1984, I45; Cahill 1986, 42; McArdle et al. 1986, 545; Noli and Avery 1988; Speth 1989, 1990).

The effective safe limit may actually be considerably less than $300 \mathrm{~g}$ or 50 percent of total calories in situations in which protein intakes oscillate rapidly between very low and very high levels. Such situations are common to many foraging groups that face alternating periods of "feast" and "famine." Bursts of meat-eating may exceed the rate at which the body can adapt to suddenly elevated amino acid loads (Speth 1989, I990).

Perhaps of greatest significance for the study of the success and long-term viability of foraging groups, however, is the recent suggestion by nutritionists that for pregnant women the safe upper limit to total protein intake may actually be considerably lower than $300 \mathrm{~g}$. A woman's protein needs increase during pregnancy, of course, and these requirements must be met in order for her to produce a viable, healthy offspring. Extremely low maternal protein intakes, below about 5 to 6 percent of total calories, may be detrimental to the health of the fetus, leading to declines in birth weight and in extreme cases to a variety of birth disorders and even death (National Academy of Sciences 1985; Martorell and Gonzalez-Cossio 1987; Winick 
1989). As maternal protein intakes increase above this minimum threshold, birth weight and fetal health generally improve. Several recent studies, however, suggest that supplementing maternal diets with protein in excess of about 20 percent of total calories (i.e., above about I0o-150 g of protein), even in diets that are otherwise balanced and calorically adequate, may lead to declines, not continued gains, in infant birth weight and perhaps also to increases in perinatal morbidity and mortality and even cognitive impairment. Premature infants appear to be the most vulnerable to high maternal protein supplements (Rush et al. I980; Rush I982, I986, I989; WorthingtonRoberts and Williams 1989, 88).

Birth weights may also decline, of course, when the mother's total calorie intake is restricted (Lechtig et al. 1978; Wray 1978; National Academy of Sciences 1985; Brooke 1987), but the decline appears to be most extreme when her diet is both low in energy and high in protein (Martorell and Gonzalez-Cossio 1987; Rush 1989; Winick I 989). This is dramatically demonstrated, for example, by data from Motherwell, a small community in Scotland, where for thirty years pregnant women were advised to consume a diet consisting of about I $500 \mathrm{kcal}$ and $85 \mathrm{~g}$ of protein (about 23 percent of total calories). Birth weights of infants from Motherwell over this period were, on average, about $400 \mathrm{~g}$ lower than those of infants born in Aberdeen during the same period (Kerr-Grieve et al. I979; Winick r989). Such a large decline in average birth weight is comparable in magnitude to the decline seen in Holland during the famine at the close of World War II (Rush 1989).

The potentially detrimental effects of high protein intakes on the health and survival of the fetus may help to explain the widespread and often seemingly irrational taboos in many foraging societies against the eating of meat by pregnant women (Spielmann $1989 \mathrm{~b}$; Speth I990). It may also help to explain the nausea and food aversions experienced by many pregnant women during the first trimester of pregnancy, a response that is often triggered by the ingestion of meat or even just by its smell (Dickens and Trethowan I97 I; Hook I978; Tierson et al. I985; Profet n.d.).

It must be pointed out that the potentially deleterious effects of high protein intakes on the health and survival of the fetus remain controversial. All of the presently available studies suffer from flaws in their research design or measurement precision, and the actual 
mechanisms involved remain unclear (see Rush I982, I 986, I989). It is also not yet clear whether high protein intakes are deleterious throughout the course of a pregnancy or only during a particular trimester. Nevertheless, if these arguments stand up to further scrutiny, they have important implications for understanding the subsistence behavior of foragers, past and present. In essence, adult foragers must normally get well over half of their calories from nonprotein sources-fat or carbohydrates-in order to remain healthy, and pregnant women must get considerably more, perhaps up to 80 percent or more of their total daily energy intake, in order to protect the health and viability of their fetus.

These nutritional factors clearly place serious constraints on the food choices made by foragers, including those made by bison hunters in the southern Plains. These hunters would have found themselves in a difficult position each year during the late winter and spring. If at least 50 percent of their total calories, and perhaps more than 80 percent, had to be obtained from nonprotein sources, either they had to have reliable access to substantial quantities of fat, which would be unlikely at these times of the year in the southern Plains (see, e.g., Speth 1983 and Bamforth I988), or they had to have access to large quantities of carbohydrates.

These observations raise an intriguing question, one that I cannot begin to answer fully here but one which is worth raising nonetheless: Was the degree of economic specialization in the procurement of bison by southern Plains hunter-gatherers, particularly the systematic exploitation of herds during the late winter and spring, ultimately limited not just by the size or accessibility of the herds but also by the hunters' access to reliable sources of carbohydrates? On the basis of these nutritional arguments, I suspect the answer is yes. The late winter and spring on the southern Plains clearly were difficult times for the bison and for their hunters (Speth I 983; Bamforth 1988). The comparatively poor grazing conditions in the region at that time of year would have provided marginal forage for bison, and many of the animals, especially pregnant and lactating cows, would have been undernourished and fat-depleted. The lean meat from these animals, in turn, would have provided a poor source of sustenance for the hunters, since they had to obtain much of their energy from sources other than protein. In the absence of reliable supplies of cultivated carbohydrates obtained through exchange with Pueblo 
communities, Plains hunters either had to amass considerable stores of bison fat during the preceding fall and early winter or they had to find reliable alternative sources of carbohydrates from wild plants.

Spielmann (1982, 248-25I), Wallace and Hoebel (1952, 72-74), and Carlson and Jones (1940; see also Creel I986) summarize the major wild plant foods that would have been available to foraging groups in the southern Plains grasslands. These include the sugarrich outer pods of mesquite (Kingsolver et al. I977, I I0; Meyer I984; the seeds are extremely high in protein and would have posed nutritional problems similar to those of lean meat), acorns, walnuts, pecans, various fruits (e.g., persimmon, hackberry, wild plum, grapes, yucca, and prickly pear), grass seeds, and a few roots, tubers, and bulbs (e.g., prairie turnip, wild onion, and Jerusalem artichoke). Despite the apparent diversity of plant foods in the grasslands, few were important sources of starch, and most were not abundant or productive enough, or sufficiently reliable, to serve as major staples, leading Spielmann $(1982,248)$ to the conclusion that "reliable sources of carbohydrates do not exist on the Southern Plains."

Far more important and productive wild plant resources, including species that are rich in starch, were concentrated in the foothills, upland plateaus, and mountains adjacent to the Plains, particularly to the west and south. First and foremost among these were sotol and agave hearts, as well as pinyon nuts, acorns, grass seeds, yucca and cactus fruits, and many other edible species (see, for example, Bell and Castetter 1937; Castetter and Bell 1937; Kingsolver et al. 1977; Winkler 1982; Meyer 1984; Ebeling 1986). Three important resources-prickly pear cactus fruits, acorns, and pecan nuts-were also concentrated adjacent to the southern Plains in central and southeastern Texas and in the Texas central coastal plain (Creel I986; Grant D. Hall, personal communication, I989). Thus, from the information at hand, it would seem that suitable carbohydrate sources probably were available to southern Plains hunters but not within the High Plains grasslands themselves. Their procurement, processing, and transport or storage, therefore, may have presented serious scheduling and logistical problems, as well as significant labor demands, that seasonally limited the degree to which southern Plains foragers could focus their efforts on bison.

While speculative, these arguments suggest that specialized bisonhunting economies, ones that relied heavily on bison as an overwintering resource, may not have been viable in the southern Plains 
until the foragers were able to enter into mutualistic exchange relations with farmers who could provide them with reliable supplies of carbohydrates. As noted earlier, an analogous suggestion has recently been advanced by Hart and Hart (1986) and Bailey et al. (1989) concerning the Pygmies. They question the viability of Pygmy adaptations in the Ituri prior to the advent of farmers into the forest. Hutterer (1982), Headland and Reid (1989), and Piperno (1989) make similar arguments for Southeast Asian and Central American tropical forest hunter-gatherers.

Pursuing this line of reasoning further, the necessary mutualistic ties between nomad and farmer in the Southwest may only have become possible after about A.D. I 300, when Pueblos on the western margins of the Plains (and possibly Caddoan groups to the east) aggregated into large, heavily agricultural communities and for the first time became dependent for much of their protein on large mammals that had to be procured far from their villages/see also Lintz and Snow, this volume).

\section{CONCLUSION}

I have briefly addressed four factors that may play a role in the emergence and persistence of mutualistic food exchanges between Plains bison-hunting nomads and corn-farming Pueblos. Hypergyny, the loss through marriage of forager women to the Pueblos, may have encouraged raiding by Plains groups, but it may also have fostered greater interdependence between the two systems by increasing the amount of time and effort the nomads devoted to bison hunting.

Nonsynchronous seasonal hunger periods in the two systemslate winter and spring for the foragers, late spring and summer for the farmers-set constraints on the time of year when food exchange would be mutually beneficial, that is, following the fall harvest and preceding the spring planting.

The depletion of large game near expanding sedentary farming communities, as well as increasing demands for high-quality protein and hides, and new time and labor constraints arising from a greater commitment to horticulture, all combined to push eastern Pueblo farmers toward mutualistic food exchanges with Plains bison hunters. The Pueblos, however, may not have crossed the critical threshold at which such exchange relationships became desirable or necessary until the major period of aggregation in the I 300 . If so, the 
mutualistic exchanges so vividly described at Pecos by the early Spanish explorers may not have been in existence very long prior to the Spanish entrada.

Finally, prior to the development of Plains-Pueblo trade, nutritional constraints affecting the bison hunters each winter and spring, particularly the need to acquire at least 50 percent, and perhaps more than 80 percent, of their calories from nonprotein sources, may have forced them to abandon the grasslands seasonally in order to exploit the oil- and carbohydrate-rich wild plant foods concentrated in a broad arc around the western and southern margins of the Plains.

In sum, the highly specialized bison-hunting economies of the southern Plains, first seen by sixteenth-century Spanish explorers and believed by many contemporary scholars to have been an adaptive pattern in the region with considerable time depth, in reality may only have become possible in the fourteenth century with the emergence of large, sedentary, surplus-generating farming communities along the eastern periphery of the Southwest. Further intensification of bison hunting in the region very likely went hand-in-hand with the historic introduction of the horse, which not only made locating and pursuing herds of bison easier but also made farming communities more accessible and carbohydrates obtained through trading or raiding easier to transport.

The conclusions reached here are at best tentative, but I hope they serve to point out the complexity of intergroup food exchange in the Southwest and elsewhere, and the need for considerable further exploration of this interesting phenomenon.

\section{ACKNOWLEDGMENTS}

I would like to express my gratitude to the Fort Burgwin Research Center and particularly to W. James Judge, Patricia L. Crown, and Katherine A. Spielmann for organizing and hosting the stimulating and productive conference that provided the stimulus for this chapter. I am also extremely grateful to Timothy Baugh, Barrett P. Brenton, David M. Brugge, Frances Levine, Christopher Lintz, Katherine Moore, David H. Snow, Katherine A. Spielmann, David R. Wilcox, and Lisa $C$. Young for their helpful comments in revising the manuscript. George F. Cahill, Alfred E. Harper, Sue O'Shea, and David Rush very generously commented at length on the protein argu- 
ments and offered many important suggestions for bringing them more in line with current thinking in biochemistry and nutrition. Final revisions of the manuscript were made while I was a Weatherhead Resident Scholar at the School of American Research in Santa Fe, New Mexico. I am grateful to the SAR for providing financial support and an ideal scholarly environment in which to pursue the ideas developed in this chapter. 


\title{
3. Coercion or Cooperation? Plains-Pueblo Interaction in the Protohistoric Period
}

\author{
KATHERINE A. SPIELMANN
}

Research focusing on the interaction between Plains and Pueblo populations has largely been concerned with trade and other cooperative relations. In part this is due to the fact that trade relations are well-documented ethnohistorically and are likely to have played a major role in the adaptations of both populations (Spielmann I991). This focus on trade is facilitated by the fact that the existence of trade is fairly easy to document in the archaeological record. Pueblo middens contain Plains lithic and shell materials, and protohistoric Plains campsites often produce bits of Pueblo glazeware.

Despite this concern with trade, however, it is also the case that relations between Pueblo and Plains populations may not have been entirely amicable. For example, ethnohistorical documents mention prehistoric attacks by Plains nomads. In particular, members of the Coronado expedition were told that Plains nomads had sacked several pueblos between present-day Albuquerque and Pecos, and had laid siege to Pecos a number of years before Spanish contact (Winship I 896, 273-274). In addition, there is some indication that Pueblos feared hunting on the Plains due to reprisals by Plains huntergatherers. Residents of San Marcos Pueblo refused to guide Spaniards out onto the Plains for just this reason (Hammond and Rey I966, 86). Fear of hunter-gatherer attacks may also have been responsible for the fairly "defensive" construction of some of the eastern border pueblos (Kidder I958, 63, 91 , 98, 129). For instance, in early Glaze III times (ca. A.D. I 450) Pecos was built as an enclosed quadrangle, and Gran Quivira sits atop a narrow mesa. Finally, historically the Apache, Navajo, Ute, and Comanche were able successfully to incor- 
porate raiding on Pueblo and other Southwestern villages into their repertoire of subsistence activities. In fact, Goodwin (I935, 6I) estimates that the Western Apache gained a significant proportion of their food through raiding Pima, Papago, Navajo, and Mexican villages.

While these various kinds of data suggest that hostile relations may have played a part in Plains-Pueblo interaction, there has been no systematic theoretical analysis of the role of this kind of interaction in the ongoing adaptation of each group. This chapter, which is designed to begin such an analysis, focuses in particular on the utility of noncooperative behaviors to Plains adaptations, because Plains hostilities are better documented than those of Pueblo groups. I address two questions. First, was raiding Pueblo villages a viable strategy for provisioning prehistoric Plains hunter-gatherers with subsistence resources? Second, was defending bison herds against Pueblo hunters an efficient strategy for Plains nomads? In essence I am evaluating the importance of parasitism and competition in a system that heretofore I have argued is mutualistic.

I should note that the following discussion focuses solely on subsistence resources, not on raiding for other purposes, such as for women or children. This is because studies of mutualistic interaction between Plains and Pueblo groups have focused on food. Cost-benefit relations for procuring and exchanging various food resources have been estimated. The cost-benefit factors involved in raiding for people would be substantially different and require separate treatment.

Previously I have used evolutionary ecology models to evaluate the mutualistic nature of Plains-Pueblo interaction (Spielmann I983, I 99I), and such models are used in this analysis as well. Interestingly, evolutionary ecologists who have been concerned with mutualistic relations are also now beginning to grapple with the complexity of interactions among and within species. Recent publications have pointed out that the consequences of interactions are outcome- and situation-specific rather than fixed. These interactions can vary from competitive to parasitic to mutualistic quite easily (Thompson 1982; Addicott 1985; Janzen 1985). In fact, some ecologists believe that interdependent relations oscillate between parasitism and mutualism over time and space and warn that there is no necessary single net type of interaction between species (Templeton and Gilbert I 985). The situation should be no less complex among 
human societies. What must be specified, therefore, are the conditions under which one would expect mutualistic, parasitic, and/or competitive behaviors to occur.

\section{RAIDING}

Ecologically, raiding can be considered a form of parasitism, in that one participant in the interaction is injured by the benefits the other participant receives. There are two forms of raiding that Plains populations could have employed: raiding stored Pueblo food for the purpose of provisioning, and raiding fields primarily for harassment in order to "encourage" the Pueblos to engage in trade. I deal primarily with the first of these forms of raiding. The second form, though possibly significant, is extremely difficult to document either ethnohistorically or archaeologically.

The viability of raiding as a strategy for resource procurement in the short run is a function of the ability of the raider to gain access to the resource and to carry away a significant quantity of it without being injured or captured. In the long run, the raider must also assess the consequences of hostile actions for future interaction. One raid may preclude further raids or eliminate the possibility of peaceful interaction through trade. These are opportunity costs that the raider must take into account. For example, the Western Apache carefully avoided armed conflict and destruction of property on their raids against Mexican villages for livestock specifically because the continuance of the Mexican populations was important for their provisioning strategy (Basso I 97 I, I9).

With regard to resource accessibility, access to stored food resources within defensible pueblos would be fairly difficult. Since both Plains and Pueblo populations had the same types of weapons (primarily bows and arrows), neither had a military weaponry advantage over the other. The defensive advantages the Pueblo villagers would have had over Plains groups are numerical (village populations were far larger than even aggregated bands of Plains hunters) and structural (pueblo walls were thick, high, and often constructed so that entry to the pueblo was restricted).

With regard to transporting booty, the fact that prehistoric Plains nomads were unmounted and were dealing with a nonmobile food resource (corn) would make successful escape extremely difficult. Equally important, the relative cost of injury would probably be sig- 
nificantly different for the two populations. The economic cost of injury to an individual with a more sedentary lifestyle, such as a Pueblo farmer, would be smaller, given that his or her abode is fixed and tasks can often be assumed by others. For mobile Plains huntergatherers, however, injury can make it impossible for an individual to remain with the group or to pursue nomadic activities. Because of these formidable problems, it is highly unlikely that raids for stored foods would be a strategy normally employed by nonmounted prehistoric Plains hunters.

To illustrate this point further, it is enlightening to examine the Western Apache, a population for whom raiding was a significant subsistence strategy (Goodwin I935, 6I). Isolating the factors that favored this strategy illuminates the Plains-Pueblo situation. These factors appear to have been (I) the mobility of the resource sought, and $(2)$ stealth and surprise in obtaining that resource. The primary resource sought by raiding Apache was livestock: horses, cattle, mules, and sheep (Thomas 1932, 6, 7; Brugge I961; Cozzens I967, 282; Basso 197 I, 16; Russell I975, 40, 44, 45, 5I, 200). Although it is reported that on rare occasions crops were the focus of raids (Russell I975, 43; Jorgensen 1983), in other cases, saddle bags of corn were left behind while only horses were taken (Brugge I96I). It may be concluded, then, that the primary resource sought through raiding was mobile.

In addition to being mobile, livestock were also fairly accessible in that they were kept outside houses in unfortified towns or frequently on open range or in corrals some distance from settlements. Stealth, surprise, and quick escape, preferably without detection, were the components of successful Apache raids. Armed conflict was expressly avoided in these expeditions. Alarm could lead to pursuit and capture (Basso 1971, 17; Russell 1975, 200-201). Once the raid had been made, return journeys of four to five days without sleep were common in order to escape pursuers (Basso I97 I, I7). Obviously, the open accessibility and mobility of livestock contrast with the restricted access and nonmobility of stored Pueblo corn.

While it may be convincingly argued that raiding will not be employed as a regular procurement strategy, armed conflict may be resorted to for other purposes having to do with resource procurement. As mentioned above, ethnohistorical documents record some form of conflict between Plains and Pueblo populations prior to Spanish contact. Is it possible to predict the situations in which the risk of 
injury and capture is worth taking in order to acquire stored Pueblo resources? To deal with this question, we can turn to the ecological literature.

In the past few years, several ecologists have taken a theoretical approach to conflicts between animals in order to predict when escalation will take place and when conflict will be avoided (Maynard Smith and Parker 1976; Parker and Rubenstein 1981). They distinguish between symmetric and asymmetric contests. Symmetry and asymmetry refer to the value the contested resource has for the competitors and the fighting ability the competitors have to acquire and/ or defend the resource. In symmetric contests, in which both resource value and fighting ability are similar between contestants, either escalation or avoidance of conflict is possible, and prediction of the outcome is difficult. In asymmetric contests, however, the best strategy is to fight when the asymmetry is in one's favor (i.e., the resource value and/or one's fighting ability are high) and retreat when it is not. Consequently, information concerning whether asymmetry exists is vital to assessing whether to fight or flee. In nature a number of cues, such as size and threat displays, are used in making decisions that keep conflict from escalating. Thus, escalated conflict is to be expected only when $(\mathrm{I})$ information about asymmetries is not available or is imperfect, or (2) the payoff to the winner is large in comparison to the risk of loss due to injury.

Based on these predictions, I would expect there to be only two situations in which conflict would take place in the Pueblo area between Plains and Pueblo populations. First, at initial contact, when the relative strengths and weaknesses of the two populations have yet to be assessed, and second, under extreme Plains subsistence stress, when the resource becomes much more valuable, thereby justifying more aggressive efforts to acquire it (Maynard Smith and Parker 1976; Parker and Rubenstein I98I). With regard to the first situation, the Coronado report of a prehistoric battle between Plains nomads and several eastern border pueblos (Winship I 896, 273-274) makes sense if it took place at the time of initial contact. Such battles would have allowed each group to assess the strength of the other. The fact that pueblos were sacked and burned, in particular one known to have large stores of corn, and yet the strategy was not again repeated by unmounted Plains bands suggests that the costs of battle may have outweighed the benefits.

In the second situation, under famine conditions Plains groups 
would not have been able to acquire sufficient meat to trade and would have had a critical need for corn to make it through the winter (see Speth and Spielmann 1983; Speth, this volume). Given that raids in response to famine were not recorded by early Spanish colonists, an alternative strategy may have been possible. Although the high value Plains bands would have placed on corn might have justified the escalation of military activity, it is more likely that the risk of injury to both Pueblo and Plains groups would promote the development of less costly social mechanisms to alleviate temporary shortages. Generalized reciprocity between trading partners may have been such a medium.

In sum, raiding is not a viable strategy for unmounted Plains nomads seeking a nonmobile resource that can be fairly easily protected inside pueblo storage rooms by a population at least as heavily armed as the raiders. Only extreme need might lead to the use of such a strategy.

The preceding is a theoretical argument concerning the utility of raiding as a subsistence strategy. Ideally, it should be tested against archaeological data. Designing such a test, however, is rather problematic. First, identifying raiding archaeologically is difficult. Burned rooms may be as much the product of accidental conflagrations as intentionally caused fires. Identifying unequivocal responses to raiding, such as defensible architecture and an increase in armament, is also fraught with problems. To what extent does "defensible" architecture imply an active strategy of defense? For example, Gran Quivira's position atop a low spur of Chupadera Mesa has been attributed to a concern for defense (Caperton I98I), but it is equally likely that such a position protected Gran Quivirans in the winter from the rigors of cold air moving from Chupadera Mesa down onto the lowlands below the pueblo.

Second, even if one were to make an argument for the existence of active defense at a particular pueblo, as Kidder $(1958,63)$ has done for Pecos, identifying the hostile agents responsible for a defensive posture is not straightforward. Intraregional hostilities, such as those between Pecos and the Galisteo pueblos, may be as much a cause for defense as interregional hostilities between Plains and Pueblo populations. The Mesa Verde area is a case in point. There, external hostile populations (the Athapaskans) formerly were thought to have caused the move to cliff dwellings. With better dating on the arrival of Athapaskan populations in the Southwest, archaeologists now 
discount them as raiders of Mesa Verde and look to more local stresses to explain the choice of site location. Even the "smoking arrow" in a Pueblo burial is not likely to provide much of a clue concerning the perpetrator of the act. Point styles found on late prehistoric and protohistoric southern Plains sites (e.g., Harrell and Washita styles) are also frequent in eastern border Pueblo middens. Thus, at this time I am less than sanguine that we will be able to identify Apachean raiding behavior for provisioning in the archaeological record.

Whether harassing raids on farmers in agricultural fields were part of the Plains hunters' repertoire is very difficult to assess both archaeologically and ethnohistorically. Defense against such diffuse sorts of attack in widely dispersed cornfields would have been problematic for Pueblo farmers, though it is reported that Pima farmers posted sentries in their fields in response to Apache raiding (Brugge I96I). Trade, however, may have been a much less costly option (see Anderson and May I982). Whether it was necessary for the Plains groups to resort to harassment depends on whether the Pueblos needed to be coerced into trade at all. Jorgensen (I983) has suggested that Apache reduction of Pueblo hunting areas may have encouraged Pueblos to trade. I have argued elsewhere (Spielmann 1988) that access to bison meat would have been highly beneficial to these populations, especially in light of overhunting and decreasing local faunal availability (see also Speth and Scott 1989; Speth, this volume). This brings us to the next question: Did the Pueblo hunt bison themselves?

\section{RESTRICTION OF ACCESS TO BISON HERDS}

Whether Pueblo hunters obtained bison themselves is a question of some importance to those of us who deal with prehistoric food exchange between Plains and Pueblo populations. When faced with only the archaeological record, it is difficult to make an unassailable case that the bison in the eastern border Pueblo middens were acquired through exchange with Plains hunters rather than through the efforts of Pueblo hunters. Thus far, the arguments for trade have centered around the fact that bison bone appears in strata of Pueblo middens that also contain durable traded items from the Plains, such as Alibates dolomite tools (Kidder 1932, 42; Spielmann 1982, 1983) or jewelry made from Plains shell species (Hayes I98 $I_{;}$Spielmann I982, I983).

It would be ideal if the bison bones themselves provided clues to 
their hunted origin. For example, if butchering differences existed between Plains and Pueblo groups, these might be detected in the faunal assemblages from eastern Pueblo sites. Unfortunately, thus far butchering patterns of Plains Apache and Pueblo groups have not been defined. In addition, the limited bison bone assemblages at eastern Pueblo sites may make this type of analysis difficult. The primary element present is rib shafts, which may not contain a "signature" that would distinguish Plains from Pueblo hunters. Nonetheless, the analysis of Plains and Pueblo butchering patterns is a potentially fruitful avenue to pursue.

John Speth, Larry Tieszen, and I explored another source of databone chemistry analysis-in attempting to identify the source of bison in Pueblo middens. Our analysis was based on work on the northern Plains by Chisholm et al. (I 986), which demonstrated that different bison herds were characterized by different carbon isotope ratios due to differences in forage. With the hope that herds on the southern Plains of the Texas Panhandle and eastern New Mexico would also be distinguishable isotopically, we tested bison bone from several contemporaneous archaeological sites in the eastern Southwest and southern Plains. Unfortunately, our data (on file with the author) indicate that there is no significant difference in carbon isotope ratios among sites in the Texas Panhandle, Gran Quivira Pueblo, and sites in eastern New Mexico near Roswell.

In the absence of clear archaeological data concerning the source of bison bones in Pueblo middens, it is informative to turn to a more theoretical discussion to ascertain the conditions under which one would expect Pueblo farmers to hunt on the Plains. The aspect of this problem that I focus on here is whether Plains populations actively discouraged Pueblos from hunting on the Plains. In the following discussion it is taken as a given that farmers occupying the eastern border pueblos would eventually wish to gain access to bison on the Plains due to probable overhunting locally.

Again, ecologists, particularly those concerned with optimal foraging theory, have much to say that is relevant to this question. The optimal foraging models I discuss make three major assumptions. First, they assume that human populations will seek to minimize costs of resource acquisition, an assumption that has been fully discussed elsewhere (see Winterhalder I $98 \mathrm{I}$ ) and thus will not be dealt with here. Second, the models assume that the predators do not have the option of hunting together and sharing the kill. This is a difficult 
proposition to deal with for the Plains-Pueblo case, but one factor that may support this assumption is the desire on the part of Plains nomads to create and maintain a specialized hunting niche so that trade with the Pueblos was favored. Ethnohistorical data from the northern Plains provide an example of "artificially maintained" demand for bison products that is relevant here. In I794 it was reported that Cree fired prairies near Fort George, Canada, to keep bison away and thus to enhance the exchange value of their own provisions (Roe I 970, 634). Again, the fact that residents of San Marcos Pueblo were reluctant to venture onto the Plains (Hammond and Rey I 966, 86) suggests some sort of boundary maintenance activity by Plains hunter-gatherers.

Third, the models assume that the resource is limited, that is, that there is not enough for all interested parties to use when they desire. I believe that this third assumption is also warranted with regard to Plains and Pueblo hunting of bison, for the following reasons. First, bison are not individual resources to be taken as one would trap rabbits or wood rats. Instead, they are social animals whose herd structure affects strategies and success rates in acquiring them. Herds cannot be manipulated repeatedly into trap situations, and an initial attempt at capture, if unsuccessful, is likely to prevent approach in the near future (Reher and Frison 1980, 45-47). In fact, the Plains ethnographic literature is full of accounts of the intricacies of enticing herds into suitable locations for kills and the precautions taken to prevent a premature beginning of the kill (Ewers I955, I63I64; Mayhall I97I, 139-I40; Fletcher and LaFlesche I972, 279; Grinnell 1972,262 ). This literature pertains to horse-mounted hunters. The situation would probably have been even riskier for hunters on foot, in that new herds would be more difficult to locate. Plains and Pueblo groups hunting in the same area would be likely to scare off or at least spook the herds, making kills by either group difficult.

Bison behavior and farming schedules make it likely that both Plains and Pueblo groups would be seeking bison at the same time. Bison hides and meat are in the best condition in the fall; Pueblo farmers tended to carry out hunts for large game (e.g., mule deer) after harvest in the fall (Parsons 1936; Lange 1959, 125-129; Ford I968; Ortiz 1969, I I2-I I4; Brown 1973; but see Cordell I977); and bison aggregate in the fall, making them more profitable targets for large-scale kills. On the southern Plains, aggregation locations, such as portions of the Canadian River valley and possibly the Pecos, may 
have been few, making it likely that Plains and Pueblo hunters would be seeking bison in the same locations.

Historically, competition for access to herds is documented between the Comanche and New Mexican ciboleros (bison hunters; Shinkle 1970, 19-20). Comanche hunters on the Plains actively discouraged New Mexican ciboleros from large-scale hunting expeditions. Carts and wagons were demolished, and only a few packhorses were allowed onto the Plains. In sum, although there may have been "enough" bison to support both Plains and Pueblo needs if taken individually, there may not have been adequate numbers of widely distributed, aggregated herds in the fall to permit hunting by different groups at the same time. Consequently, bison can be defined as a limited resource over which the Plains and Pueblo hunters might be expected to compete. The question is whether active efforts by plains groups to maintain exclusive access to bison would be costeffective.

Ydenberg and colleagues (1986) have recently developed a model to predict when short-lived, high-density resource patches, such as aggregated bison herds, should be defended by central place foragers through interference competition. Both Plains and Pueblo hunters can be considered central place foragers in that they acquired a resource, bison meat, which was then transported to a central place, the Pueblo village, for trade and/or consumption. Interference competition is any activity that slows or prevents another individual, group, or species from resource acquisition, thus decreasing the rate of food delivery to their central place.

These researchers have defined four possible tactics for two foragers when faced with mutual use of a rich resource patch: (I) enter and forage without interfering; (2) forage and interfere; (3) wait until the other is finished and then forage; $(4)$ abandon the patch and forage in poorer areas. As discussed above, given bison behavior, neither the first nor the third option is possible, since mutual foraging is likely to disturb the herd and waiting until kills have beeri made by one group is likely substantially to decrease the chance of the second group making a successful kill. The choice then remains between interfering or leaving the patch.

The Ydenberg model predicts the conditions under which a group or individual should interfere and the conditions under which retreat is the better option. These predictions are based on differences in payoff to the two contestants if they stay in the patch. Four factors can 
influence payoff differences: travel distance, productivity of the home area, efficiency of resource capture, and proficiency in interfering.

Differences in travel distances affect relative returns from a patch because they represent differences in investment made in reaching that patch. Ydenberg's model predicts how this variable should affect relative payoffs from competition. Travel distance, however, is a multifaceted variable in the Plains-Pueblo case, which complicates its use in assessing relative payoffs to the two groups.

The Plains-Pueblo situation is not simply one of two individual predators setting out from separate home bases, competing for the same resource, and then returning to their respective homes. First, group size is very likely to differ between the two in that the Pueblo hunting party may be comprised of about twenty to thirty men (Parsons 19361, while the Plains hunting party can conceivably include the whole band of a hundred or more people. Second, while it is true that the Pueblo hunters will make a round trip to and from the Pueblo village, the Plains band has several potential options. They may return to a home base, move the home base to the kill, or process meat and travel to a pueblo to trade it. Thus, comparing relative costs for travel, given the variety of possible scenarios, is of limited utility in that different combinations of group size and travel distance could favor either the Plains or the Pueblo hunters. I will therefore move on to the remaining variables, which are more useful in comparing Plains and Pueblo payoffs.

Relative home area productivity is in part a measure of the value of the contested resource patch to each of the opponents. This variable is used to measure whether the same or a similar resource can be obtained elsewhere without substantially raising the cost of acquiring it. The model assumes that each opponent values the contested item equally. Again, the Plains-Pueblo case requires an elaboration upon this simple assumption. The value of the resource for Pueblo and Plains groups was quite different. For Pueblo hunters, the protein and probably the hides would be the aspects of value, whereas for the Plains groups, the caloric content of the fat (Speth and Spielmann 1983; Speth, this volumel, as well as the protein and hide products, would be important. The issue then becomes whether the home territories of Pueblo hunters are "richer" in protein than the Plains are in both calories and protein.

Elsewhere I have discussed the fact that much of the prehistoric southern High Plains was carbohydrate-poor and therefore did not 
offer many alternatives to bison for acquiring calories (Spielmann 1982; see also Speth, this volume). The low-density, low-predictability carbohydrate resources such as shin oak, walnuts, ground cherry, and scattered stands of mesquite would have been adequate for the low-density, highly mobile Paleo-Indian and Archaic hunter-gatherer populations on the Plains. Protohistoric hunter-gatherer population densities, however, appear to have been much higher in that protohistoric southern Plains sites are larger and more numerous than are Archaic and Paleo-Indian sites (Hughes I978). The fact that bands of several hundred Plains nomads visited the Pueblos also indicates a relatively high density of hunter-gatherers on the Plains in the protohistoric period. Access to corn from farming populations on the Plains and in the Southwest may have been the key to the survival of these groups.

The productivity of Pueblo hunting areas depends in part on whether large game has been hunted out. Turkeys and other small game were available to Pueblo farmers, however, as were beans to complement the amino acids in corn (Wetterstrom 1986, I I 6). Consequently, I would tentatively conclude that the Pueblos had more options open to them to procure protein in central New Mexico than the Plains groups had to procure calories on the Plains. The consequence of this difference is that Plains groups receive a higher payoff if they compete successfully for bison, and should invest more in this competition. At some point it will be more efficient for Pueblo hunters to forage for smaller game at home.

Efficiency in resource acquisition is difficult to evaluate, especially if we are comparing a small Pueblo hunting party with an entire Plains band. A small group of hunters may efficiently pick off several bison at a water hole to meet their needs, while a larger Plains group may need to organize a communal drive to obtain quantities of meat. However, whether we are dealing with a whole band or a small Plains hunting party, it is likely that some costs, such as search costs, would be less for Plains groups since they were monitoring herd locations on the Plains all summer rather than entering the Plains during the fall. Transport from the kill would also be more efficient for Plains hunter-gatherers in that they employed dog transport. Pueblo populations did not keep dogs large enough to carry packs or drag travois. Overall, the Plains bands were probably more effective bison hunters, again making payoffs to them higher if they competed successfully for exclusive access to the resource. 
Finally, with regard to proficiency of interference, while their weaponry is fairly similar, more intimate knowledge of the terrain might give Plains nomads an edge over Pueblo groups in direct encounters. Numerical advantage would clearly give Plains groups the edge if entire bands were engaged in bison hunting.

In sum, given competition for access to bison, the payoff to the Plains hunters for gaining exclusive access to bison would probably be higher for a variety of variables, including relative hunting and fighting efficiencies and lack of alternative resources in their area. Consequently, one would expect them to interfere with Pueblo access to the herds.

Given that it is in the interest of Plains hunters to maintain exclusive access to bison herds, should the Pueblos continue to attempt to hunt bison on their own? The answer to this question relates to the models discussed earlier concerning tactics in conflict situations. In contests between known opponents, and we can assume PlainsPueblo opponents "knew" one another, then a quick assessment of differences and immediate withdrawal of the subordinate group is the best strategy. If the Pueblo hunters are the subordinates in most if not all encounters, as the above data on payoff differences suggest, then it behooves them not to enter the Plains at all for bison but instead to establish some sort of trading tie to acquire meat and fat indirectly. This may account for the dearth of ethnohistorical references to Pueblo hunting on the Plains. It is only with improvement in arms and transport capabilities (acquisition of the horse) that we find Pueblo groups hunting on the Plains historically.

The above is a theoretical argument concerning the degree to which one would expect Pueblo farmers to be hunting bison on the Plains. At this point, given the difficulties with the archaeological record discussed at the beginning of this section, the most profitable avenue for testing the argument involves the creation of a simulation model. The model could be used to assess the payoffs of interference competition between Plains and Pueblo hunters. The variables discussed above--travel distance, productivity of the home area, efficiency of resource capture, and proficiency of interfering-could be modeled quantitatively. With the simulation it should then be possible to define more rigorously the conditions under which one would expect to find the defense of bison herds by Plains hunter-gatherers or bison hunting by Pueblo farmers. 


\section{CONCLUSION}

In previous works I have argued that Plains-Pueblo interaction is mutualistic in that both populations benefit from the interaction. Mutualism, as we have just seen, may arise in part out of competitive interactions with regard to Plains faunal resources. Plains populations may have actively discouraged Pueblo hunters from seeking bison in the face of competition for a limited resource. Actually proving that this was the case is another problem entirely.

Analysis has not focused on the costs of Pueblo hunting and transport on the Plains in the absence of conflict. Given the Pueblo's limited transport capabilities and problems with searching for herds on the Plains, I would expect that producing small surpluses of corn to trade is far more efficient than trundling out to the Plains to search for and kill a few bison that then have to be hauled home on one's back (see Speth, this volume).

Even with the acquisition of the horse, Pueblo groups appear to have continued to focus on trading rather than hunting for bison on the Plains. A number of ethnographies mention that Pueblo villages would mount trading expeditions to the Plains to acquire bison products and horses in exchange for bread and blankets (White 1935; Parsons 1936; Lange 1959, I 52; Ortiz 1969, 172-173).

Relations between Pueblo and Plains populations were not entirely amicable, but the above discussion suggests that, for a number of independent reasons, relations were probably not that overtly hostile. Interestingly, the most active Pueblo hostilities may have been directed toward other Pueblo groups. Ecological theory and data show that mutualistic relations often arise between two species in response to competitive relations between one of these species and a third (Thompson 1982; Templeton and Gilbert 1985). Competition among relatively clustered pueblos (Wilcox I 98 I a) or between Pueblo clusters (Kessell 1979, 98, 24 I, 244, 249, 257, 29 I), for increasingly limited large game may also have selected for mutualistic relations between eastern border Pueblos and their Plains neighbors.

Thus the answer to the question in this chapter's title is that prehistoric Plains-Pueblo relations probably were dominated by cooperative behavior, with little overt hostility. Coercion, if it existed, was probably of a type that will be difficult to observe archaeologically. The main point is that the outcome-trade-was a primary provi- 
sioning strategy for both populations and the major form of interaction between the two groups. It is therefore important that we continue to focus our efforts on understanding and documenting this form of interaction in the archaeological record.

\section{ACKNOWLEDGMENTS}

This chapter is a first attempt to grapple with issues raised in a friendly fashion by skeptical colleagues, such as Art Jelinek, concerning the source of bison in eastern border Pueblo middens. It has benefited from discussions with John Speth and comments from an anonymous reviewer. Any flaws of reasoning are mine alone. 


\title{
4. Evidence for the Manufacture of Southwestern-Style Culinary Ceramics on the Southern Plains
}

\author{
JUDITH A. HABICHT-MAUCHE
}

As many of the chapters in the present volume demonstrate, a complex system of economic interdependence and cross-cultural interaction linked the farming villages of the Rio Grande and Pecos River valleys with the nomadic bison hunters and seminomadic Plains Village groups of the southern Plains during the protohistoric period (A.D. I450-1700). Contact and trade with the Pueblo Southwest is reflected archaeologically in the widespread distribution of exotic materials that either have their source in the basin and highlands of the Rio Grande region of New Mexico or are believed to have been traded to Plains groups through the pueblos of that region. The most common materials of this type recovered from protohistoric sites on the southern Plains include obsidian from the Jemez Mountains of north central New Mexico (Baugh and Terrell I982; Baugh and Nelson 1987), turquoise from the Cerrillos mines north of the Galisteo Basin, shells from the Pacific Coast and the Gulf of California, and sherds of Rio Grande decorated and culinary ceramics.

Despite the increasing sophistication with which these materials are being identified and analyzed, their interpretive role within studies of Plains-Pueblo interaction has remained largely one of markers of contact and trade. Little attention has been given to the function of specific objects or materials within the protohistoric exchange network. Studies of Plains-Pueblo trade do not address the question of how the processing, production, distribution, and use of these materials and objects structure, and are structured by, the contact situation. Material culture studies, such as those of Quimby and Spoehr (I95I), however, have indicated that often there is a direct correlation between changes in the composition, form, function, and 
technology of certain classes of material culture and changes in the nature and intensity of cross-cultural interactions.

This chapter addresses the issue of material culture change through the analysis of Southwestern-style culinary ceramics recovered from protohistoric sites on the southern Plains. The analysis of the adoption and use of Pueblo-type cooking and storage vessels by protohistoric bison-hunting groups on the southern Plains represents an excellent case study of the correlation between material culture change and cross-cultural interaction. The large body of ethnohistorical and archaeological data that exists relating to the development, structure, and intensity of the interaction between the protohistoric Pueblo farmers of the Rio Grande and the nomadic and seminomadic bisonhunting groups of the southern Plains allows one to study in greater detail the context in which this technological development took place.

Mineralogical evidence suggests that certain southern Plains groups were producing culinary pottery patterned after contemporaneous Pueblo vessels from north central New Mexico between approximately A.D. I 500 and I 700 . The transmission of such a highly developed technological complex across cultural boundaries clearly reflects a system of interregional interaction of far greater scope and intensity than does the reciprocal exchange of small quantities of raw materials and finished products that characterized all earlier episodes of Plains-Pueblo contact. These Southwestern-style cooking and storage vessels are the material manifestation of an entire Pueblo foodways complex that was adopted by certain protohistoric southern Plains groups in conjunction with the acquisition of Southwestern agricultural foods. In this context, the spread of Pueblo ceramic technology to the southern Plains can be seen as part of a highly integrated and complex system of economic specialization and regional interdependency.

\section{SOUTHWESTERN CERAMICS IN THE CONTEXT OF} PROTOHISTORIC PLAINS-PUEBLO INTERACTION

According to the testimony of sixteenth- and seventeenth-century Spanish explorers and colonists in New Mexico, each fall large bands of nomadic bison hunters traveled to Pueblo villages located along the western margin of the High Plains in order to trade products of the hunt for the agricultural produce, craft specialties, and raw mate- 
rials of the settled villagers. The archaeological data from both the Southwest and the southern Plains indicate that this system probably developed in response to a series of complex demographic, ecological, and socioeconomic changes during the late fourteenth and early fifteenth centuries and was apparently well established by about I450 (Baugh 1982; Spielmann 1982, I983). In particular, beginning in the fifteenth century, pottery from the upper Rio Grande region of New Mexico was traded to groups on the southern Plains with increasing frequency. In fact, on many protohistoric sites in the Texas Panhandle, Southwestern ceramic types make up the entire ceramic assemblage (Habicht Mauche i988).

Not only did the quantity of Southwestern ceramics reaching the southern Plains change at this time, but so did the types of ceramics. In the preceding late prehistoric period, Southwestern trade ceramics had been limited primarily to the finer painted types. In contrast, on protohistoric southern Plains sites, significant quantities of unpainted Southwestern-style culinary wares have been found in association with remains of glaze-painted ceramics known to have been manufactured at pueblos in the Rio Grande valley of New Mexico. The quantity, types, and widespread distribution of Southwestern ceramics on protohistoric southern Plains sites seem to indicate that by the end of the fifteenth century, pottery had shifted from being a relatively exotic gift item to a basic utilitarian commodity in this exchange network. The reasons for this shift are probably linked to the functional roles these ceramics played in the storage, transport, and processing of the agricultural food products that formed an important focus of protohistoric Plains-Pueblo interaction.

Most of the glazeware sherds recovered from protohistoric southern Plains sites date from the Intermediate Glaze period (Glaze C and D; Ca. A.D. I425-I500) to the Late Glaze period (Glaze E and F; ca. A.D. I 500-1650 + / in New Mexico (Honea I973). The distribution of these glaze-painted wares on the southern Plains is generally restricted to larger "base camp" or village sites located along the major east-west water courses that traverse the region (Spielmann I983, 264; Hughes n.d., 80). Jar or "olla" forms appear to have been preferred over bowls. Among the Pueblos, these glazeware ollas are usually associated with food and water storage. This preference for storage-type jars and their limited distribution may reflect a practice of caching ceramic vessels at repeatedly occupied base-camp sites (Spielmann 1982, 318). Glazeware ollas may also have been used to 
transport corn and other agricultural products acquired in trade with the eastern Pueblos.

As noted above, in addition to glazewares, protohistoric sites all across the southern Plains have yielded significant quantities of Southwestern-style culinary pottery. In contrast to the glazewares, unpainted culinary sherds have been found both at the larger, more permanent base camp or village sites and at the smaller, more ephemeral camps located near playas, tributary streams, and other upland locations on the High Plains.

Small, squat jar forms predominate among these culinary ware assemblages from the southern Plains (Hughes n.d., 8o). Among the eastern Pueblos such vessels are usually associated with food processing activities, particularly cooking. The widespread distribution of this class of ceramics thus would seem to reflect the introduction of Pueblo cooking technology to the southern Plains. The use of ceramic vessels allows for a far wider range of food preparation techniques than would otherwise be possible. For example, in contrast to stone boiling in containers of wood, basketry, or hide, which requires the constant replacement of hot rocks to maintain cooking temperatures, ceramic pots can be left on a fire unattended for extended periods. The use of ceramic vessels also allows food to be cooked over an open fire with less loss of nutrients and with less danger of burning, carbonization, and dehydration than is associated with other forms of direct heat processing, such as roasting (Arnold I985, I $28-\mathrm{I}_{3} 6$ ).

In addition to their use in processing maize and other agricultural produce acquired in trade, ceramic vessels may have made it possible for nomadic hunter-gatherer groups on the southern High Plains to take advantage of a wider range of wild grasses and other seed-bearing plants such as amaranth, sunflower, goosefoot, Canadian ryegrass, and mesquite (Lintz r986a, 68-74) that may not have been digestible or palatable without the long-duration cooking methods that these vessels facilitated. Pottery of this type would also have been extremely useful for other food processing activities, such as the rendering of bone grease. This laborious process requires longduration simmering of small bone fragments in water until all of the grease has been extracted (Vehik 1977, I 71 ). The remains of culinary pots on sites that probably represent upland hunting and processing camps may reflect such activities. Bone grease would have been an important source of calories for hunting groups living on the High 
Plains, especially during the winter and early spring (Speth and Spielmann 1983, I9).

\section{SOUTHWESTERN-STYLE CULINARY CERAMICS ON THE SOUTHERN PLAINS}

Small quantities of Smudged Corrugated, Smeared Indented, and Blind Indented Corrugated sherds have been reported from excavations and surface collections from protohistoric sites in the Texas Panhandle (Spielmann 1982, 319, 324), South Texas Plains (Word I965; Parker I982, 6, 59), and southwestern Oklahoma (Baugh I982, I02-104; Swenson I986, I16). Corrugated culinary pottery with more-or-less obliterated or smoothed-over surfaces was produced throughout most of the upper Rio Grande valley during much of the Classic period (ca. A.D. I 325-I 450). The Smeared and Blind Indented Corrugated ceramics found on the southern Plains are probably contemporaneous with the Intermediate Glazes (Glaze $C$ and D) found in the same contexts (Spielmann I982, 319).

Far more prevalent, however, are the remains of a thin, noncorrugated pottery with characteristic finely striated exteriors. These ceramics are highly reminiscent of the Faint Striated ware recovered from Late Glaze (Glaze V) levels (A.D. I 525-I650) at Pecos Pueblo (Kidder and Shepard 1936, 316-320). Similar noncorrugated striated pottery was produced at a number of pueblos throughout the upper Rio Grande during the sixteenth and seventeenth centuries and represents the culmination of the culinary ware tradition among the eastern Pueblos. As in the Southwest, striated culinary sherds from the southern Plains are probably contemporaneous with the Late Glaze period (Glaze E and F) ceramics found on these sites.

Thus, although these Southwestern ceramic types are often found mixed together in surface collections and shallow excavations of protohistoric southern Plains sites, they seem to represent at least two distinct temporal components. An earlier component consists of the Intermediate period glazes and contemporaneous Smeared or Blind Indented Corrugated wares, while a later component is associated with the Late period glazes and the noncorrugated striated wares. In most assemblages, Intermediate glazeware sherds occur in far greater frequency than do the relatively rare Smeared or Blind Indented Corrugated sherds. In the case of the Late period glazes and striated wares, however, these ratios are reversed, with striated culinary 
wares being far more prevalent in most assemblages than the contemporaneous Late period glazes.

This shift seems to indicate a fundamental change in the availability and/or economic importance of these two basic classes of ceramics through time on the southern Plains. The proliferation of Southwestern-style striated ware on protohistoric sites on the southern Plains may be explained by the proposition that by the sixteenth century certain southern Plains groups were producing ceramics based on contemporaneous Pueblo prototypes. This local production may have been sufficient to meet the limited demand for cooking and storage vessels among local Plains groups. Conversely, dependence on glaze-painted and culinary pottery acquired in trade with the Southwest would have decreased.

Published reports of archaeological surveys and site excavations record the ubiquitous presence of thin, dark sherds with faintly striated exterior surfaces and fine "sand and mica" temper in protohistoric contexts throughout the Texas Panhandle (Marmaduke I975, 91; Katz and Katz 1976, 67; Hughes et al. 1978, I52-I 53; Guidry et al. 1979, V85), the South Texas Plains (Word I963, 45, 48; Word I 965 , 88; Parsons 1967, 59-60; Johnson et al. 1977, 99; Booker and Campbell 1978, 30; Northern I979, 56-58; Parker 1 982, 63-65), and southwestern Oklahoma (Baugh 1982, 72-75; Swenson 1986, II4-II 7 ). These sites belong to three regionally distinct but roughly contemporaneous archaeological complexes (Fig. 4.I).

Concentrated along the upper drainages of the Red River in the Texas Panhandle are the remains of the Tierra Blanca complex (Hughes n.d., 79). These sites appear to represent the camps of nomadic bison hunters who maintained close economic contacts with the eastern Pueblos of the Rio Grande. Thin, dark sherds of striated culinary pottery dominate the relatively sparse ceramic assemblages from these sites. They occur in association with a variety of Intermediate to Late period glazewares manufactured in the pueblos of north central and northeastern New Mexico. A small series of radiocarbon dates (Hughes n.d.; Katz and Katz 1976; Spielmann I 982, 2871, in conjunction with the cross-dating of associated Rio Grande glazewares, indicates a tentative time range for the Tierra Blanca complex of about A.D. I450-I650.

A second protohistoric complex, known as the Garza complex, has been defined for the South Texas Plains (Johnson et al. I977). Garza components also represent an economy largely focused on the 


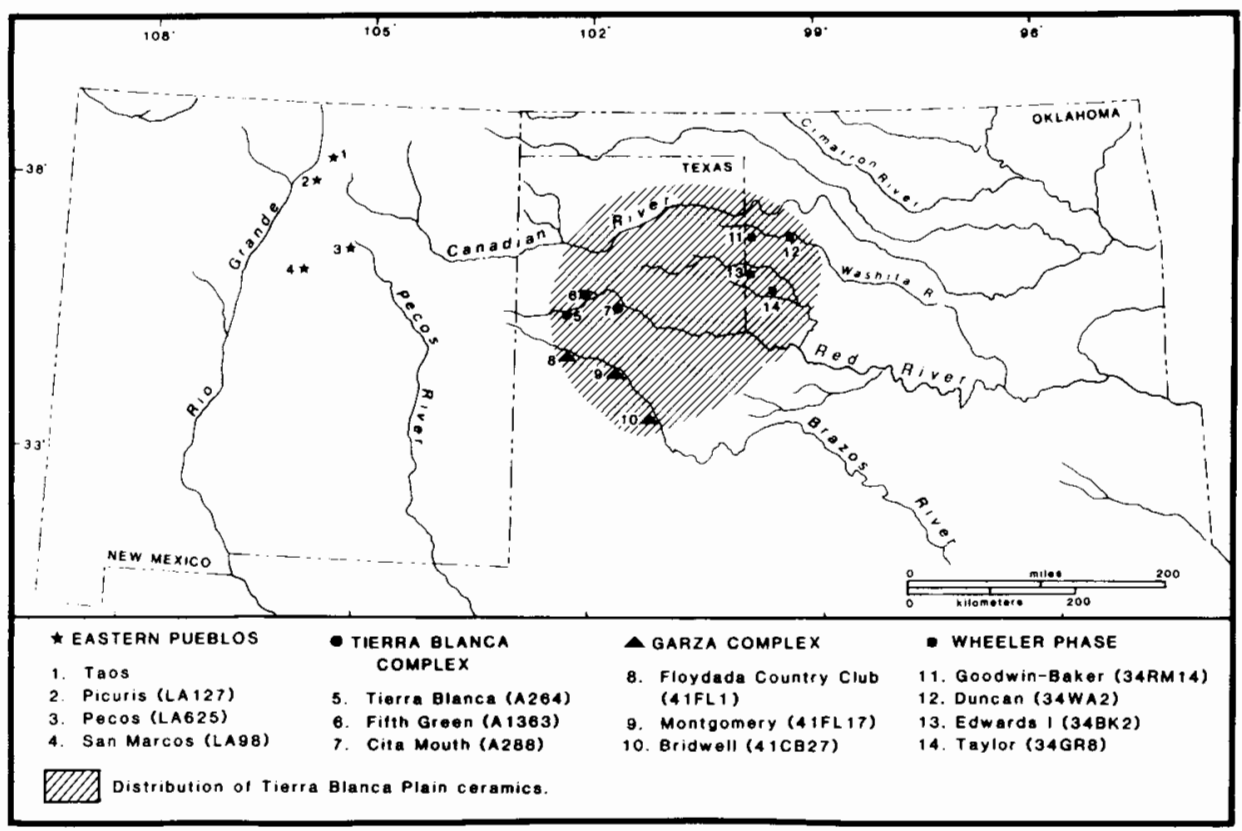

FIGURE 4. I. Distribution of Tierra Blanca Plain ceramics on the southern Plains.

hunting and processing of bison. A series of larger Garza sites that cluster along the White River in Blanco Canyon just below the rim of the Llano Estacado escarpment, however, appears to be the remains of more substantial, semisedentary villages. Dates derived from radiocarbon (Holiday et al. I 983) and obsidian hydration (Baugh I986, I79) techniques indicate that the Garza people occupied the South Texas Plains from around the middle of the fifteenth century to well into the early eighteenth century.

Farther east, among the mixed-grass prairies of western Oklahoma, are found the remains of protohistoric, semisedentary villages that depended on a mixed economy of bison hunting and limited horticulture (Hofman I984b). Radiocarbon, archaeometric, and obsidian hydration dates all seem to indicate that this archaeological complex, known as the Wheeler phase, flourished in western Oklahoma between A.D. I450 and 1750 (Baugh I986, I69-17I). Both the Garza complex and the Wheeler phase appear to represent the remains of Plains Village groups that, for one reason or another, were in the process of developing an increasingly more mobile, bison-oriented 


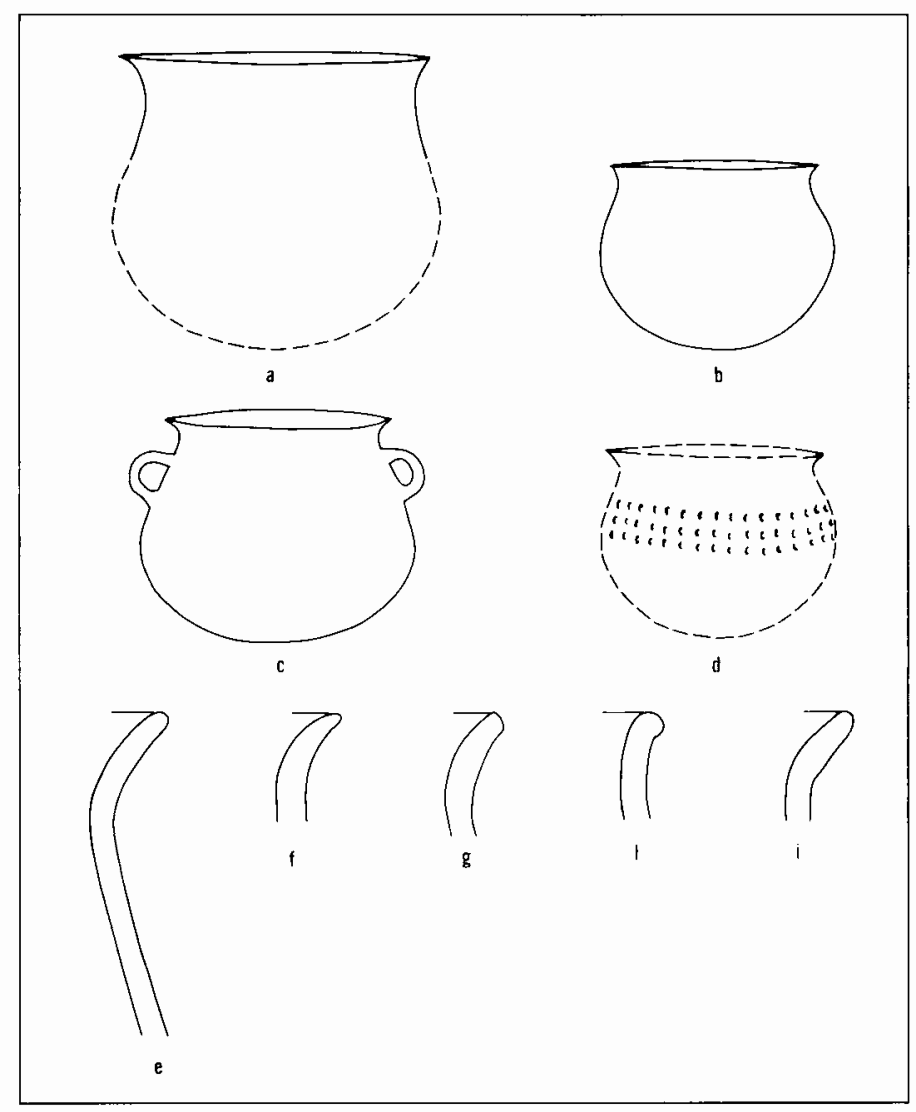

figure 4.2. Tierra Blanca Plain vessel forms.

lifestyle during the protohistoric period (see Baugh, this volume). At both Garza and Wheeler sites, Southwestern-style striated pottery is found in association with a relatively large proportion of indigenous Plains Village ceramic types, such as Edwards Plain and Little Deer Plain, as well as small amounts of Rio Grande glazewares and eastern Caddoan tradewares.

In 1985 , as the result of discussions at the Southern Athapaskan Ceramics Conference (Baugh and Eddy 1987 ), all of the striated culinary pottery from the southern Plains was assigned to a single type, which was given the name Tierra Blanca Plain. Typical Tierra Blanca Plain vessels can be described as small (less than $20 \mathrm{~cm}$ in height), squat, globular to slightly elongated jars with rounded bases and 
gently everted rims that meet the body of the pot in a smooth curve (Fig. 4.2). Exterior surfaces are often completely covered by distinctive, fine parallel striations. Decoration is extremely rare and is limited to several rows of punctations placed around the shoulder of the pot.

Most pastes are densely tempered with fine to medium-coarse fragments of crushed crystalline rock and/or unconsolidated sand. Small to moderate amounts of finely divided mica are usually present. Tierra Blanca Plain pastes, however, rarely contain as much mica as the so-called micaceous culinary wares produced by the Northern Tiwa, Northern Tewa, and Jicarilla.

\section{COMPARISONS WITH RIO GRANDE STRIATED CERAMICS}

As noted above, Tierra Blanca Plain ceramics from the southern Plains closely resemble Rio Grande Striated ware produced by the Pueblos of north central New Mexico, including Pecos, the Galisteo Basin pueblos, and several of the southern Tiwa pueblos in the vicin-

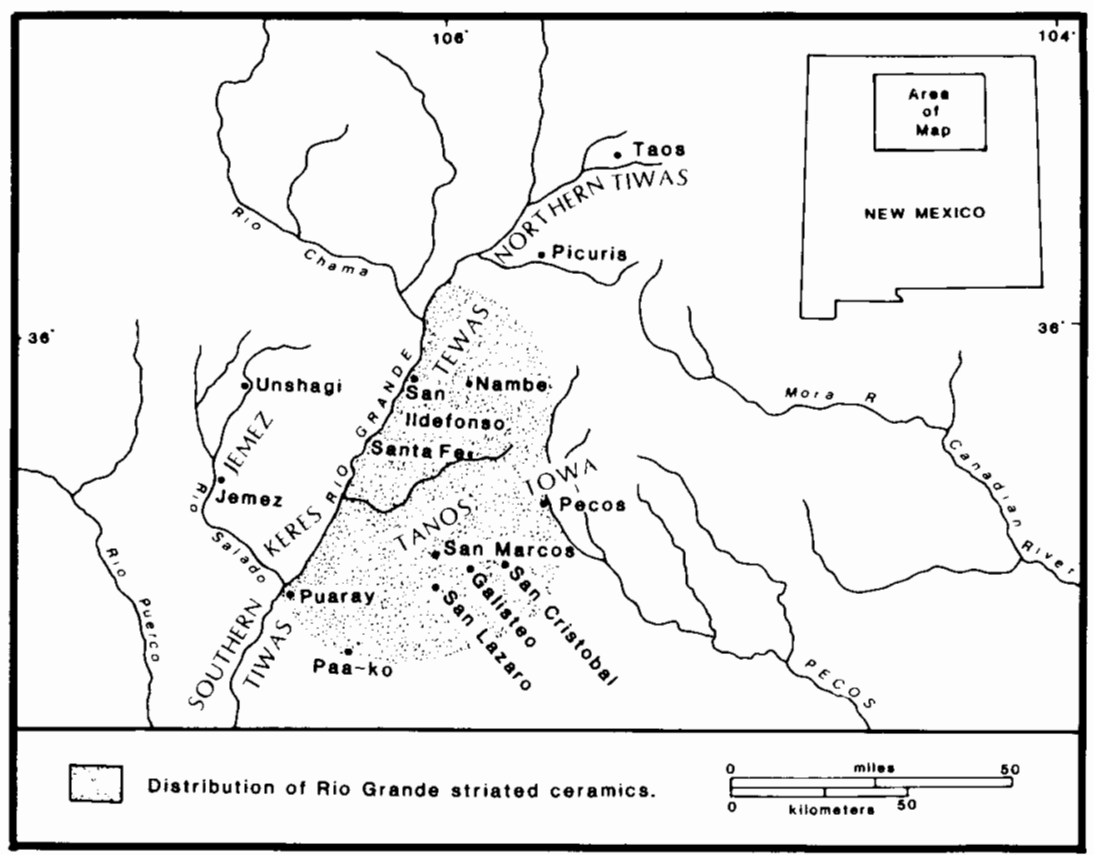

FIGURE 4.3. Distribution of Rio Grande striated ceramics in New Mexico. 
ity of Albuquerque (Fig. 4.3). The largest and most complete sample of Rio Grande Striated ware comes from the excavations at Pecos and has been described by Kidder and Shepard (I936). Less detailed published descriptions also exist from the sites of Pa-ako (Lambert 1954) and Puaray (Tichy 1939). In addition, I analyzed samples of striated ware sherds from the Kidder Collection at Pecos and from the Archaeological Conservancy's excavations at San Marcos for comparison with the Tierra Blanca Plain material from the southern Plains (Habicht Mauche I 988). The results of this analysis confirmed that general similarities in terms of construction technique, paste characteristics, form, finish, and decorative attributes indicate that the striated culinary ceramics from both the Southwest and the southern Plains are part of a single ceramic tradition, equivalent in typological terms to what is usually referred to as a ware.

One of the major differences between Tierra Blanca Plain and Rio Grande Striated ceramics is in average vessel size. There appears to have been a general preference for smaller vessels on the southern Plains. The average orifice diameter for Faint Striated jars from Pecos is 25.4 to $29.2 \mathrm{~cm}$ (IO-II $1 / 2$ inches) (Kidder and Shepard I936, 328), while the orifice diameter of measurable Tierra Blanca Plain jars ranges from only $\mathrm{I} 6.5$ to $\mathrm{I} 8.5 \mathrm{~cm}$. Tierra Blanca Plain vessels generally have thinner walls than do the striated ware vessels from the Rio Grande. This trend may also reflect a preference for relatively smaller vessels in southern Plains assemblages, in that there is often a direct structural correlation between overall vessel size and wall thickness.

Smaller vessels may have been favored by the nomadic and seminomadic peoples of the southern Plains because they were lighter and less cumbersome to transport. The presence of small loop handles on some of these jars may also have facilitated transport by allowing the pots to be securely fastened to dog travois or backpacks. Striated culinary pots with handles are extremely rare in the Rio Grande area, being reported from only a few of the smaller vessels from Glaze V levels at Pecos.

Other differences between the Rio Grande Striated ware and the Tierra Blanca Plain ceramics recovered from protohistoric sites on the southern Plains are far more subtle. Attribute analyses (Habicht Mauche I988) have demonstrated that it would be extremely difficult to separate sherds of Tierra Blanca Plain ceramics from those of Rio Grande Striated ware on the basis of the presence or absence of stylistic and technological attributes alone. Quantifica- 
tion of the range and distribution of variability within these attributes, however, indicates that there are significant differences between these two regional assemblages of Southwestern-style culinary ware. Although discernible differences occur among sites, the striated ware from individual sites in the Rio Grande area is internally quite uniform. In contrast, Tierra Blanca Plain ceramics from sites on the southern Plains vary far more in terms of specific attribute categories both within and between individual site samples. The attribute categories in which this variability is most clearly recognizable include the following:

Surface texture and finish. There is a greater range of variability in surface treatment among the Tierra Blanca Plain assemblages (Table 4.I, sec. A), reflecting less uniformity in production overall and the presence of varying levels of craftsmanship within the sample from the southern Plains.

Paste. There appears to be more diversity in the size, relative density, and mineralogical composition of nonplastic inclusions within the sample of Tierra Blanca Plain ceramics than in the striated ware from the eastern Pueblo area (Table 4.I, sec. B). This diversity probably reflects the utilization of a broader range of raw materials, as well as possible differences in the way in which these materials were processed.

Color. A broader range and higher percentage of lighter and/or brighter surface and paste colors characterize the Tierra Blanca Plain assemblages (Table 4.I, sec. C). Again, this pattern may reflect the use of a wider variety of raw materials, especially clays, and a preference for different firing atmospheres, schedules, and/or fuels.

This variability, however, is not randomly distributed across the southern Plains. Distinct regional differences exist among the striated pottery assemblages from each of the various protohistoric complexes defined from the Texas Panhandle, South Texas Plains, and western Oklahoma. These differences do not correspond to known differences among site or regional assemblages of Rio Grande Striated ware from the Southwest and therefore cannot be attributed to the existence of trade alliances between different groups of Plains bison hunters and specific pueblos or Pueblo provinces.

In summary, this pattern of overall broad-spectrum attribute variability combined with discrete regional variation is not the pattern that one would expect to find if all of these ceramics were being traded to the southern Plains from a limited number of known villages 
Table 4.1. Comparison of Physical Attributes in Tierra Blanca Plain and Rio Grande Striated Assemblages

A. Exterior Surface Finish

\begin{tabular}{lccccc}
\cline { 2 - 6 } & Rough & Grainy & Smooth & Burnished & Polished \\
\hline Tierra Blanca & $1.7 \%$ & $93.5 \%$ & $2.0 \%$ & $1.4 \%$ & $1.4 \%$ \\
Garza & 6.3 & 88.4 & 4.0 & 0.9 & 0.4 \\
Wheeler & 5.1 & 74.4 & 15.4 & 2.6 & 2.6 \\
Pecos & 0.9 & 99.1 & 0.0 & 0.0 & 0.0
\end{tabular}

B. Paste Texture

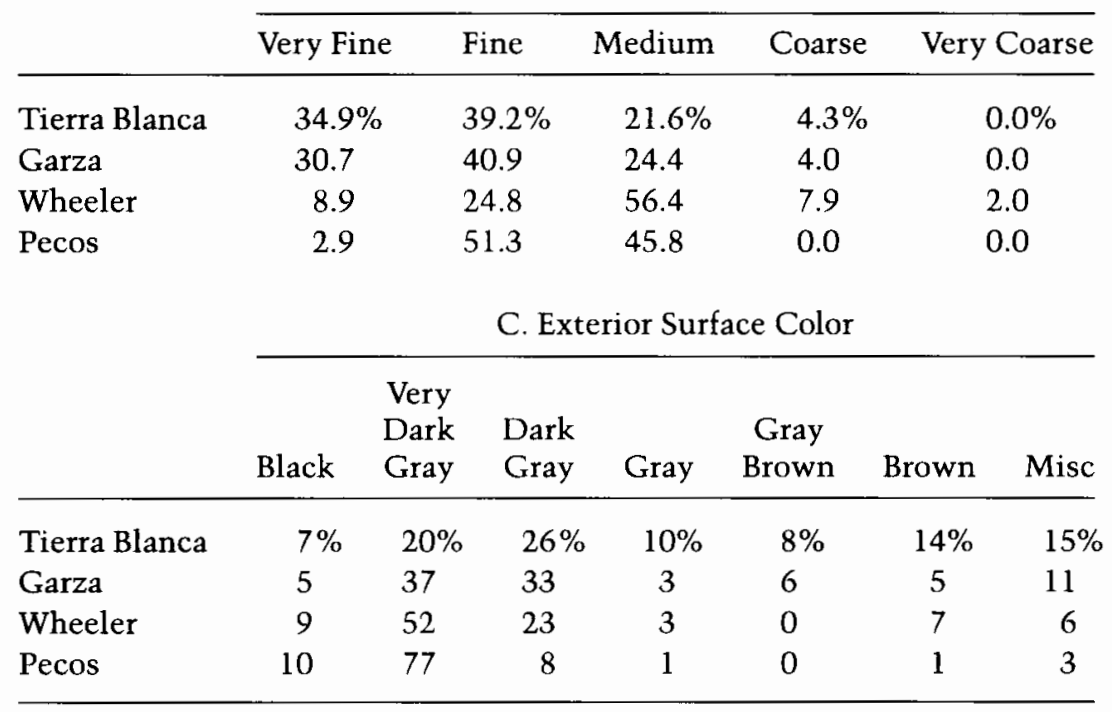

located along the eastern frontier of the Pueblo Southwest. On the contrary, the pattern of attribute variability presented here strongly supports the proposition that striated culinary ceramics based on Southwestern prototypes were being produced locally on the southern Plains.

If this striated pottery was in fact indigenous to the southern Plains, the regional differences recorded for Tierra Blanca Plain assemblages could stem in part from the local stylistic preferences of Plains potters as well as from differences in the quality and composition of local raw materials. Furthermore, potters among the more nomadic societies of the southern Plains would not have had the 
same opportunity as the settled villagers of the Rio Grande to collect resources for pottery production in the same locality. As a result, they would have had to adapt the pottery-making techniques they had learned from the Pueblos to make use of a larger range of less uniform, geographically dispersed resources. Such conditions would naturally have led to the production of finished vessels characterized by a broader range of physical and technological attributes.

\section{MINERALOGICAL ANALYSES OF TIERRA BLANCA PLAIN CERAMICS}

If, as the above discussion suggests, the major differences between Tierra Blanca Plain and Rio Grande Striated ceramics primarily reflect differences in the availability and use of local raw materials by contemporaneous potters in the Southwest and the southern Plains, then it should be fairly simple to distinguish these differences mineralogically. To test this hypothesis, a comparative petrographic analysis was performed on a sample of striated ware sherds from the southern Plains (Habicht Mauche 1988). This sample was drawn from eight sites, including three Tierra Blanca complex sites from the Texas Panhandle, three Garza complex sites from the South Texas Plains, and two Wheeler phase sites from western Oklahoma.

Sherds from each site were sorted into distinct categories based on macroscopic differences in paste composition and texture. One sherd from each category was selected and a standard thin section prepared. Each thin section was examined petrographically to determine the type and range of mineralogical and lithic inclusions present in each. This information was then compared with the known geology of the region around each site to determine whether the sampled ceramics were of local or exotic origin.

\section{Tierra Blanca and Garza Complexes}

The most prominent geomorphic feature of the southern High Plains is the Llano Estacado, an isolated plateau of approximately 40,000 square miles which extends from the Canadian River on the north to the Edwards Plateau on the south and which is bounded on the east and west by steep erosional escarpments. The surface of the Llano Estacado is supported by a widespread sheet of continental deposits derived mainly from the eastern range of the Rocky Mountains. These sediments, known as the Ogallala formation, accumulated as 
coalescent alluvial fans during the early and middle Pliocene (Evans 1949, 3; Seni I980, 1). Secondary deposition of calcium carbonates at or near the surface of the Pliocene plain led to the formation of the well-known resistant caliche caprock (Evans 1949, 6; Evans and Brand 1956, I6; Hood and Underwood 1978, 12).

All three of the Tierra Blanca complex sites sampled for analysis are located in the northern Llano Estacado on or near small tributary streams of the Prairie Dog Town Fork of the Red River. Petrographic studies indicate that over 80 percent of the Tierra Blanca Plain sherds sampled from these sites were manufactured from materials locally available on the southern High Plains. The most common paste type recorded for striated ware sherds from the Tierra Blanca complex sites is densely tempered with well-sorted, subrounded to subangular grains of unconsolidated quartz-feldspar sand (Fig. 4.4). Occasionally coarse fragments of loosely consolidated calcareous sandstone are also present. The source of the nonplastic inclusions in these

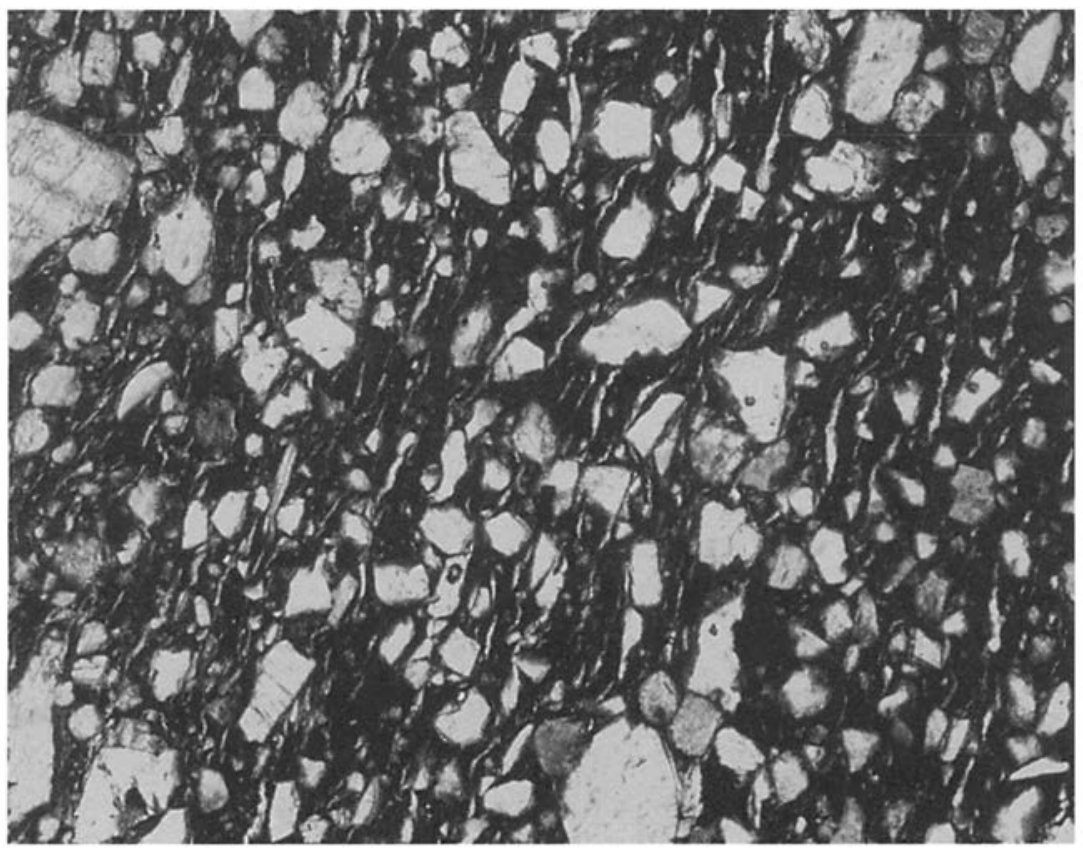

FIGURE 4.4. Photomicrograph of well-sorted, subrounded quartz-feldspar sand temper common in Tierra Blanca complex pastes $(\mathrm{mag} .=40 \times)$. 


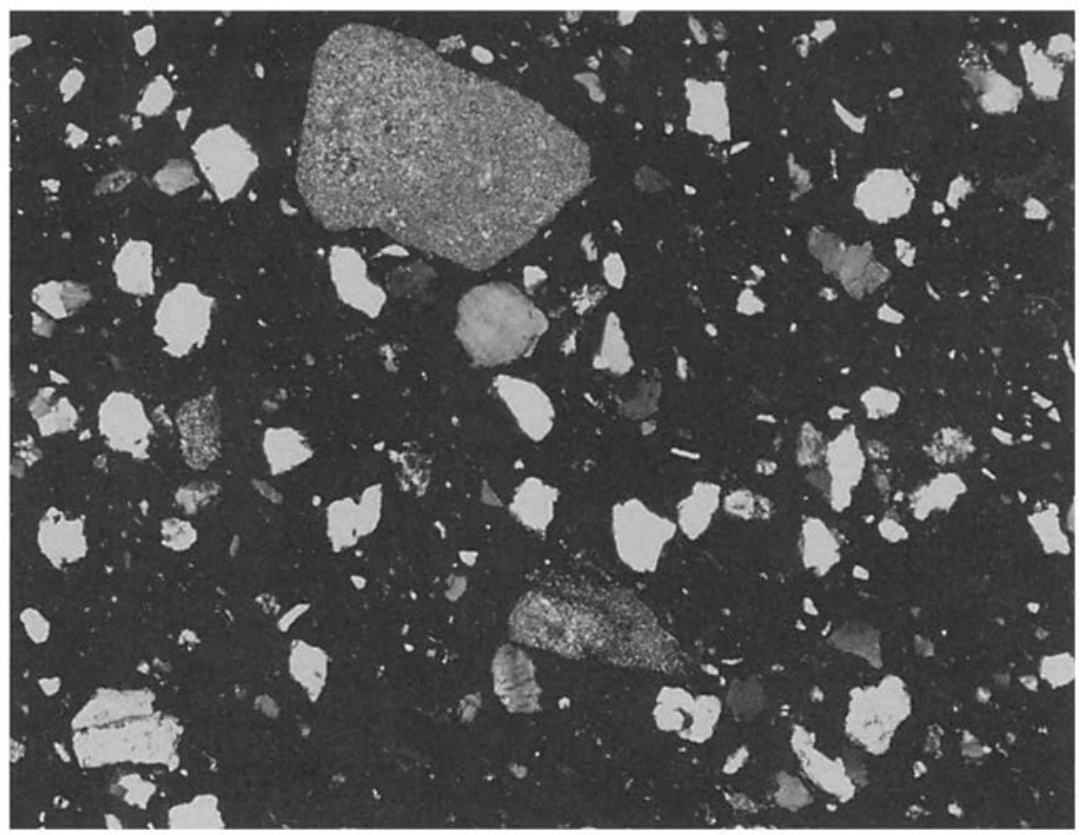

FIGURE 4.5. Photomicrograph of sandstone and caliche temper common in Garza complex pastes ( $\mathrm{mag} .=40 \times)$.

pastes is most likely the sands and sandstones of the locally ubiquitous Ogallala formation. Below the caliche caprock, this formation consists primarily of unconsolidated fine- to medium-textured, reddish tan to pale pinkish gray quartz-feldspar sands marked by discontinuous zones of weak cementation by calcium carbonate (Frye and Leonard I957, I3).

All of the Garza complex sites analyzed for this study are located in the bottomlands of Blanco Canyon along a twenty- to thirty-mile stretch of the White River below the southeastern escarpment of the Llano Estacado. A common temper type encountered at all three Garza sites consists of abundant grains of subrounded quartz, calcareous sandstone, and caliche (Fig. 4.5). A likely source of this tempering material is a unit of loosely consolidated calcareous sands that forms the floor of Blanco Canyon in the vicinity of these sites.

The petrographic data from Tierra Blanca Plain ceramics collected from the three Garza complex sites thus tend to parallel the data 


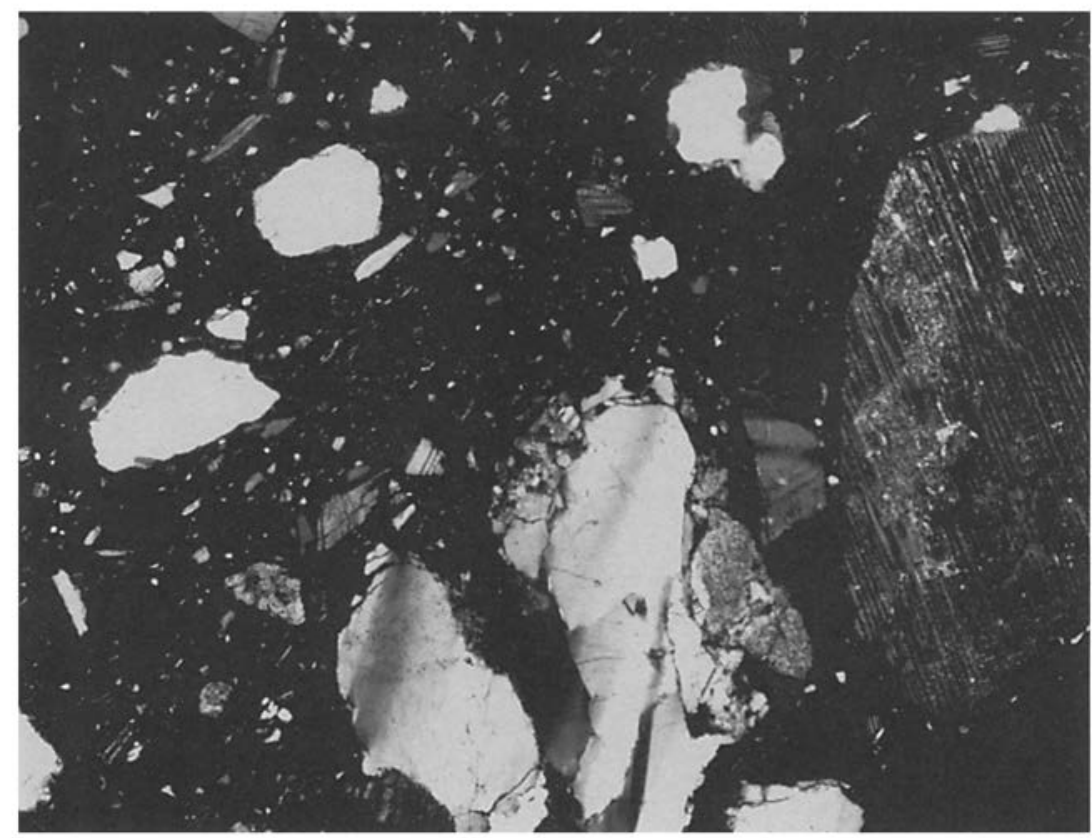

FIGURE 4.6. Photomicrograph of coarse, angular granite temper common in Wheeler phase pastes $(\mathrm{mag} .=40 \times)$.

obtained from the Tierra Blanca complex sample. Local potters in both areas appear to have favored the loosely consolidated sands and calcareous sandstones of the Ogallala formation as temper.

Wheeler Phase

Tierra Blanca Plain ceramics have been identified in the ceramic assemblages from two late Wheeler phase sites. Both of these sites are located on the west side of the North Fork of the Red River in western Oklahoma.

The majority of the striated ware pastes from both Wheeler phase sites are characterized by medium-to-coarse angular inclusions of a very distinctive light pink to fleshy red weathered granite (Fig. 4.6). In color, texture, and composition, these granite inclusions correlate remarkably well with published descriptions of the Cambrian granites that outcrop throughout the western Wichita Mountains in the vicinity of Lake Altus (Merritt I 958). This strong correlation between 
the paste composition of Tierra Blanca sherds from Wheeler phase sites and the local geology of southwestern Oklahoma provides striking evidence of the local production of Southwestern-style culinary pottery on the southern Plains.

Along with this evidence for local production, the petrographic data from the southern Plains also indicate that a small percentage of striated ware vessels was obtained from the Rio Grande Pueblos in trade. Stylistic and technical analyses indicate that Tierra Blanca Plain ceramics most closely resemble protohistoric culinary ware from north central New Mexico. It is therefore not surprising that most of the intrusive Rio Grande Striated sherds identified from protohistoric southern Plains sites can be traced to areas such as Pecos Pueblo in the northern Pecos drainage and the Galisteo Basin, San Pedro Valley, and Bernalillo area in the central Rio Grande drainage.

In sum, the variability and distribution of tempering materials found in the Tierra Blanca Plain sample supports the hypothesis that protohistoric southern Plains groups were manufacturing their own Southwestern-style culinary pottery, using a wide variety of locally available raw materials rather than relying on trade with the Rio Grande Pueblos of New Mexico to obtain this ware. The variability in paste composition mirrors the relatively high degree of variability recorded for stylistic and technological attributes among Tierra Blanca Plain assemblages from Texas and western Oklahoma. In addition, differences in paste composition are not randomly distributed but instead clearly reflect regional differences in the availability of specific geologically distinct resources.

\section{CONCLUSION}

The chronicles of the earliest Spanish explorers indicate that by the middle of the sixteenth century the southern High Plains east of New Mexico were occupied by tipi-dwelling dog-nomads whose unique and highly specialized lifestyle centered on the pursuit of the bison. According to Spanish documents (e.g., Gallegos 1927; Hammond and Rey 1940, I953), large groups of these hunters traveled each fall to the pueblos located along the eastern frontier of the High Plains.

These contacts occurred on a regular, predictable basis and were of relatively long duration. It is even reported that some of these 
nomadic hunting groups spent the entire winter camped "under the eaves" of the pueblos (Hammond and Rey I940, 258). Communication between ethnic groups was facilitated by the development of a complex system of sign language. Some Spanish observers also report that, as a result of their extensive and long-term interaction with one another, certain Plains nomads and Pueblo villagers had come to learn each other's language (Gallegos 1927,29 ).

The intensive and long-term nature of this particular contact situation would clearly have facilitated, even encouraged, the transmission of material objects, technologies, ideas, and behavioral complexes between cultural groups. Ethnohistoric and ethnographic studies of culture contact and acculturation, however, have shown that acceptance of foreign traits into any cultural system is neither wholesale nor indiscriminate (see, e.g., Quimby and Spoehr I 95 I and Secoy 1953). Rather, societies are very selective, constantly accepting, rejecting, and reworking materials, technologies, and ideas to fit their own culturally determined needs and perspectives. Thus, in order to understand the reasons behind the spread of Southwestern ceramic technology to the southern Plains, one must first understand the functional position that ceramics in general held within the protohistoric Plains-Pueblo interaction system.

The distribution of Rio Grande glazeware and culinary ware on protohistoric sites on the southern Plains mirrors the fundamental changes that took place in both the nature and intensity of PlainsPueblo interaction during this period. As trade in agricultural foodstuffs increased throughout the late fifteenth and early sixteenth centuries, southern Plains groups may have been exposed to and adopted many of the traditional Pueblo facilities and technologies for transporting, storing, processing, and consuming these resources.

Ceramic vessels and ceramic technology were an important feature of this Pueblo foodways complex. The significant increase reported in the relative number of Intermediate period Rio Grande glaze-painted ceramics recovered from protohistoric contexts on the southern Plains is probably a direct reflection of the increasing importance of these ceramic vessels in the transport and storage of maize and other agricultural products acquired in trade with the Rio Grande Pueblos. At the same time, small amounts of Southwesternstyle culinary pottery first became common on southern Plains sites. By the Late Glaze period, striated ware was even more abundant and 
had a much wider distribution on protohistoric sites than did the decorated ware.

Among the historical eastern Pueblos and Southwestern Athapaskan groups, technologically and stylistically similar striated vessels are known to have been used primarily for cooking and other food processing activities. This Southwestern foodways complex may have been particularly important to the Tierra Blanca complex people, who probably entered the southern Plains as nomadic huntergatherers with no established traditions or technologies for the processing and consumption of agricultural foods. Grains, such as maize, often require long-duration cooking to make them palatable and to release their full nutritional potential. The excellent refractory properties of Southwestern culinary pottery made them technologically well suited for such sustained, direct-heat cooking processes as boiling. The preparation of Pueblo-style soups or stews in clay pots may have been adopted by Tierra Blanca groups to augment traditional methods of processing wild foods, such as pit roasting, drying (jerking), and hide boiling.

The presence of Southwestern-style culinary pottery on protohistoric sites in the South Texas Plains and western Oklahoma requires some additional explanation. As Garza complex and Wheeler phase groups began to focus more intensively on bison hunting at the expense of traditional horticultural activities, they may have had to obtain more of their agricultural foodstuffs through trade than through local production. Nevertheless, they would have retained their traditional facilities and technologies for storing, processing, and consuming these resources. These facilities and technologies included a well-developed indigenous Plains Village ceramic tradition.

Thus, al though the mineralogical data strongly indicate that Tierra Blanca Plain ceramics were being manufactured in the vicinity of both Garza complex and Wheeler phase sites, it is difficult to imagine why people with an existing culinary ceramic tradition would adopt a distinctly different one. Intermarriage and the exchange of women as a means of cementing social and economic alliances between Plains and Pueblo groups may have been responsible in part for the appearance of Tierra Blanca Plain ceramics in Plains Village assemblages (see Speth, this volume). Such social and demographic interactions are, however, hard to detect in the archacological record. Certain physical properties, such as impermeability, durability, 
and resistance to thermal shock, may have made Tierra Blanca Plain ceramics technologically superior and therefore a desirable alternative to traditional Plains Village culinary wares. The polished, smudged interiors, simple rounded contours, and thin vessel walls that characterize Southwestern-style striated wares are indicative of such properties (Rye I98I, 27), but extensive physical tests would be needed to address such a hypothesis. Nevertheless, it should be noted that Tierra Blanca Plain ceramics never replaced the traditional Plains Village ceramic types. They merely augmented them in the ceramic assemblages from these Plains Village complexes.

The evidence presented here indicates that certain southern Plains groups were producing culinary ware based on contemporaneous Pueblo prototypes between A.D. I 500 and I700. The adoption of Southwestern ceramics and ceramic technology by southern Plains groups was directly related to the functional role that these ceramic vessels played in the transportation, storage, and processing of the agricultural products that formed a central focus of the protohistoric Plains-Pueblo exchange network.

The recovery of Pueblo-type cooking and storage jars from sites occupied by nomadic and seminomadic bison-hunting groups on the southern Plains thus documents more than a simple reciprocal exchange of material goods or an isolated instance of "trait diffusion" between cultural groups. Instead, these vessels reflect the existence of an intensive, long-term contact situation that facilitated the dissemination of detailed technological knowledge and integrated behavioral complexes across cultural boundaries. 


\title{
5. Upland Prehistoric Maize Agriculture in the Eastern Rio Grande and Its Peripheries
}

\author{
DAVID H. SNOW
}

The majority of the chapters in this volume are concerned with the interaction between farming and hunting populations. Prior to about A.D. I450, however, there may have been no specialized hunting populations residing on the southern Plains (see the chapters by Spielmann, Speth, and Lintz in this volume). Nonetheless, interdependent relations may have characterized interactions among preA.D. I450 Pueblo (and Pueblo-likel farming populations of the Rio Grande frontier and beyond. The nature of such possible interrelations between the core Pueblo farming populations and their peripheral neighbors is the focus of this chapter.

The thesis of this chapter is that successful maize production, by which is implied the production of a mature crop during most years, may not have occurred frequently at elevations above 6,000 feet, which are characteristic of the region (Fig. 5.I). Consequently, alternative strategies for coping with variable growing season lengths at these elevations may be discernible in the archaeological record.

A review of the relevant literature suggests that among such strategies might be $(I)$ the consumption in quantity of green, or immature, corn, and $(2)$ the development (or intensification) of intercommunity ties to facilitate an exchange for corn, including seed corn. Among the kinds of ties that might have developed are those documented between the eastern Pueblos and the southern Plains Apache, which Spielmann ( 1982 ) has characterized as a form of mutualism involving the exchange of protein resources for carbohydrates. Given the availability of game at higher elevations, a mutualistic exchange of meat and other animal products for corn may have developed prior to the arrival of Athapaskan populations in the area. 
Maize agriculture is often characterized as a risky endeavor in many areas of the Southwest (Hack 1942; Bradfield I97I; Adams 1979). Nevertheless, if Pueblo culture can be defined, one of its key components has to be the importance of maize cultivation and its consumption. Maize has been estimated to have comprised 65 to 80 percent of the prehistoric Pueblo diet (R. I. Ford in Snow 1976, I94; Wetterstrom I986, 49).

A great deal of research in Southwestern prehistory addresses the issue of adequate precipitation over time and space, and its impact on Pueblo agriculture. Few Southwestern archaeologists, however, have adequately addressed a second key variable in the production of a successful mature crop of maize: the length of the growing season. Bradfield (197 I, 6) neatly summarized the significance of growing season length to the Hopi farmer: "These variables the Hopi farmer has to weigh. ... [I]f he plants his field too early, he runs the risk of losing the whole crop to a late spring frost (and so have to re-plant the field, dangerously late in the season); if he plays safe and plants late, he may find his yield seriously curtailed by an early frost in the autumn."

In contrast, some students of the Southwest seem unperturbed by the potentially critical nature of the growing season. For example, concerning the Chaco Canyon area, Gillespie $(1985$, I 8$)$ refers to it as that season "of some interest to farmers (and apparently to Southwestern archaeologists)." He argues that "It is unclear how critical frost-free period length is in assessing prehistoric agricultural potential. The possibilities that fast-maturing strains of corn were used and that recent frost-free periods are not indicative of effective growing season suggest that periods of less than IIO-I30 days are not necessarily prohibitive."

Given these contrasting views concerning the impact of growing season length on corn production, the following discussion reviews the possible effects of variation in growing (or frost-free) season length on prehistoric maize agriculture among the peripheral neighbors of the eastern Pueblos.

Much of the region of concern--essentially the upper Rio Grande and adjacent Pecos, and upper San Juan river drainages of northern New Mexico and southern Colorado (see Fig. 5.I)-lies above 6,000 feet in elevation. Significant exceptions are the valley and terraces along the lower Chama River and the valley floor of the Rio Grande itself, which lie at about 5,000 feet. 


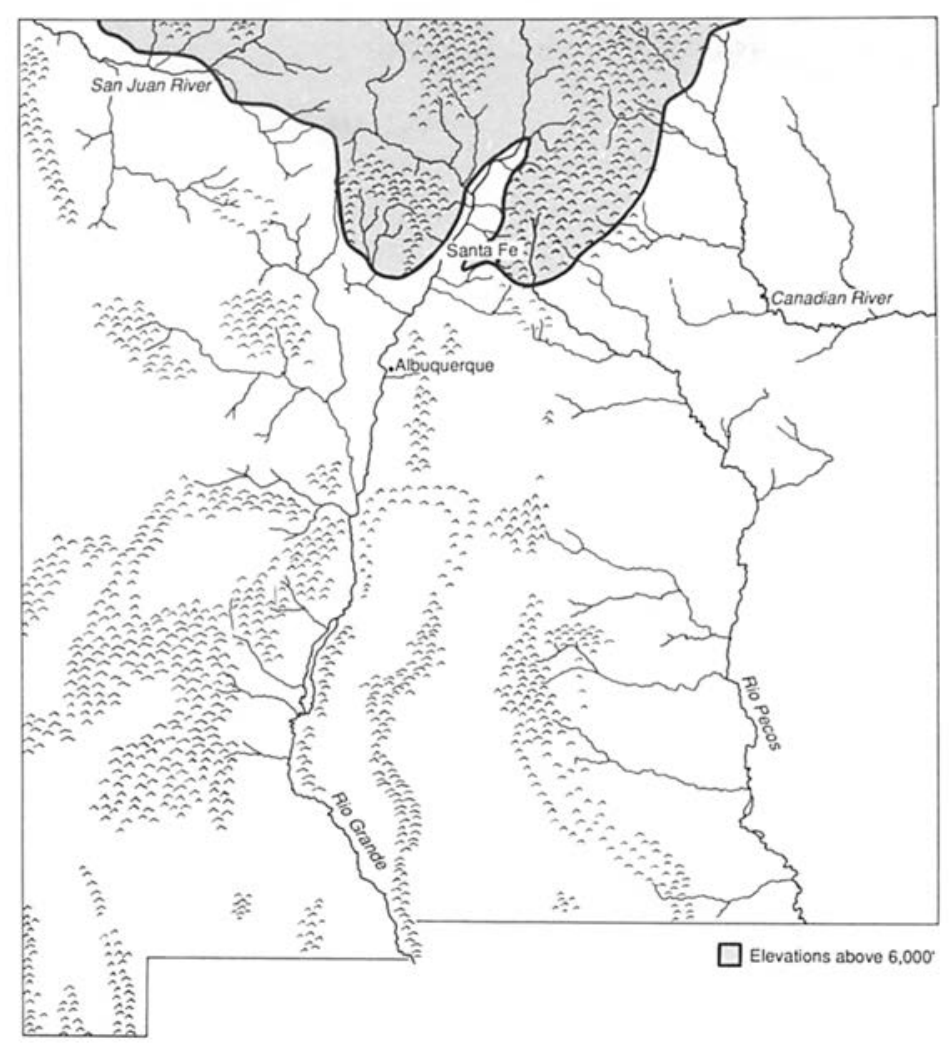

FIGURE 5.I. Approximate limits of the 6,000-foot elevation in the northern Anasazi and Rio Grande areas.

If prehistoric growing season length at elevations above 6,000 feet was highly variable, as it is today in northern New Mexico and adjacent areas, relying on a mature maize crop from one year to the next would have been an undependable strategy. If maize, in fact, constituted a significant portion of the prehistoric diet in such areas, green corn may have constituted a significant portion of that diet. One consequence of harvesting immature corn (or risking the loss of most or all of the crop to killing frosts) is the loss of potential seed corn for the following year's plantings. Thus, if green corn was a significant factor in prehistoric diet in areas above 6,000 feet, the purchase of seed corn (and perhaps additional mature corn for winter consumption) from lower elevations may have characterized relations between core and peripheral farming populations. 
THE EASTERN PUEBLO AND PERIPHERY INTERACTION ZONE

Interactive systems between core Rio Grande and periphery farming populations in the area are documented historically but are not well known. Because recent studies of Pueblo-southern Plains interactions rely on the biased Spanish accounts of dog nomads trading with the sedentary agricultural eastern Pueblos-clearly a novel sight in Spanish eyes and one that therefore received greater attention and reporting-those accounts understate or mask the presence of parttime horticultural Athapaskans occupying the eastern flanks of the Sangre de Cristo Mountains and the upper Rio Grande valley from the sixteenth through the eighteenth century. That these groups maintained ties with their Pueblo neighbors cannot be doubted. Moreover, the spotty archaeological record for the broad region under consideration suggests that Pueblo populations have interacted with possibly non-Pueblo neighbors in these same peripheral areas since the ninth or tenth centuries. It is this interaction that is of concern here.

The "Anasazi-ization" of the margins of the San Juan Anasazi core area (essentially the Four Corners region) may have occurred as a result of the rapid spread of dependency on maize in the diet of peripheral populations (Winter 1976; Berry 1985; Snow I990). Until about the thirteenth century A.D., the Rio Grande region was clearly on the periphery of sociocultural developments to the west and was characterized by dispersed populations "living in relative isolation" (Cordell I984, 300). These populations appear to have subsisted as much if not more by hunting and gathering as by cultivating crops. By about A.D. I250, however, increased population and settlement density and the addition of many of the cultural trappings of the Western Anasazi (Wendorf and Reed I955) suggest the intensification of agricultural pursuits to the point that the term Rio Grande Anasazi has often been applied in the region. The cultural trappings of the Anasazi lifestyle (and presumably, therefore, reliance on agriculture) become more and more attenuated north and northeast of the Rio Grande valley (Eighmy I 984). Nevertheless, they are important evidence of a continuing interaction between the core and the periphery.

Maize horticulture and associated technology (manos and metates, digging sticks, the remains of maize itself, and an increasing use of storage facilities) denote the acceptance of maize cultivation during the Developmental Period in the Rio Grande area (ca. A.D. 900-I I 50 ). 
This complex appears later in the major northern valleys and intermontane regions of southern and southeastern Colorado, although maize itself may have been accepted from both Pueblo and eastern sources. Interaction between the Rio Grande and southeastern Colorado as early as the tenth to eleventh centuries, for example, is evident from the increasing occurrence of Anasazi ceramics and other trade items from western sources (Wedel I950; Wendorf 1960; Campbell 1976; Winter 1976; Snow 1981).

I have suggested elsewhere (Snow 1984, I29) that those Pueblo elements that characterize sites along the eastern and northeastern periphery of the Rio Grande-and that are seen through the bias of Anasazi-colored glasses-may with equal likelihood represent evidence of increasing interaction between non-Anasazi groups and Rio Grande Pueblo populations (see Stuart and Gauthier 1981, 308-309; Winter 1986). Traditionally, the archaeological evidence has been interpreted as representative of an Anasazi population expanding eastward and northeastward (Wendorf and Reed I 955). By the same token, however, it can also be argued that pre-A.D. I 200 Rio Grande (indigenous) populations were primarily hunter-gatherers like their eastern and northeastern neighbors, all of whom adopted Anasazi trappings as maize cultivation became an increasingly important basis of their diet (see Habicht-Mauche, this volume). More important, and rather than involve the unnecessary mechanism of a Rio Grande Anasazi population expanding eastward, it might be argued that the peripheral populations, while perhaps benefiting from maize adoption-and the attendant technology and tools-could not partake of full-scale agricultural independence because of their inability to produce for preserve) sufficient seed corn in the face of environmental limitations.

Increasing dependence on maize throughout most of the Rio Grande and its peripheries may not have been as successful in higher elevations, along the upper edges of the major valleys, owing to the vagaries of a shorter growing season due to killing frosts above 6,000 feet. Adaptive strategies to compensate for poor crops must have been developed.

\section{A MOST MARGINAL PURSUIT}

Crop Production Risks

Adams's study of Hopi maize crop production well illustrates the risks a short growing season presents to farmers: 
Areas with a growing season with a mean length less than I 40 days and a standard deviation of is days (similar to Keams Canyon) will be avoided as bad risk areas in terms of crop success. More specifically, with a standard deviation of 15 days in growing season, an average growing season I 36 days in length could produce a crop failure due to frost la growing season less than 120 days| once every 5 years, a I 44 -day growing season would expect a crop failure due to frost once every 20 years. It would seem a safe assumption that a growing season yielding a crop loss more than once every Io years would be a prohibitive gamble for horticulturalists. (Adams, I 979, 293)

In this regard, both Hack (1942) and Bradfield (I97 I) noted that the two key factors affecting the date of planting at Hopi are soil moisture and the expectation of a killing frost. According to Bradfield (1971, 6), early maize plantings are located in gullies near the foot of the mesas "where the nocturnal radiation from the gully walls protects the plants from frost" (see Cordell i979a, 68, for similar observations in Frijoles Canyon). Late spring and early fall frosts at Hopi occur more frequently over the main valley floor, where cold, damp air hangs at night.

Other areas of the Southwest also experience short growing seasons. In the Pecos area, Spielmann has calculated that "in about one year out of three the Pecos growing season would fall below i 20 days" (1982, I60) because of killing frosts (see Adams I979). Ford (1977, 143) noted that while the growing (frost-free) season at Picurís Pueblo lasts $\mathrm{I} 28$ days, "these figures are deceptive since the last killing frost in the spring may occur in June and the first severe frost can strike in late August. The close proximity of the Picuris Mountains makes cold air drainage an additional problem" (see also Adams I9791.

Finally, in a study of Navajo farming, Burton (cited in Bailey and Bailey I 982, 36) concluded that maize could be grown with certainty at elevations below 6,000 feet. Above that level, frost becomes an increased risk factor and results in frequent failure of the crop to mature. Much of the upper Rio Grande region and adjacent areas lie above that level.

In sum, though precipitation variability critically affects the success of maize cultivation in lower portions of the semi-arid Southwest, the length of the frost-free season becomes of major importance in higher areas. The increased security in having adequate moisture above 6,000 feet is offset by the increased danger of killing frosts either in the spring or fall above that level. 


\section{Growing Season Requirements}

While I argue that growing season length is of critical importance in understanding variability in corn production in the Southwest, it is extremely difficult to determine what the growing season is (or was) for maize. Figures range from I 5 I to I 20 days or even less: 80 days at Chimney Rock in south central Colorado (Eddy 1974, 69-70); "three to five months" (Forde 1963, 223) and I I 5 to I 30 days at Hopi (Bradfield I971, 6; see also Minnis I980, 26); I 20 days for modern hybrids (Cordell I979a, 7; Cordell I984, I 86); I I o to I 20 days (Hack 1942, 23; Carter 1945, 88-89; Schoenwetter and Eddy I964, I 20); I 20 days (Adams I979, Gillespie I985); Ioo to I Io days in the Taos Valley (Woosley I980, 25); and I I days along the lower Chaco (Allen 1977, 133/. For Navajo corn the examples include 90 to I 40 days (Hill I938, I4 in Bailey and Bailey 1982); 90 to I 50 days (Gregory 1916, 67 in Bailey and Bailey 1982); "at least I20 days" (Bingham I 979, I 4 in Bailey and Bailey I982); and I Io days (Reher I977, I33).

Experiments performed with growing Navajo corn varieties, unfortunately at Bismark, North Dakota, are reported in Bailey and Bailey (I982). The five varieties required I IO and I 20 days in I9 I 4, with the longest (Navajo Red) taking I20 days. Only one variety was reported for the I9I 6 crop, and it required I 24 days, in contrast to I I 5 days for the same variety in I9I4. The Bismark experiments indicated that the varieties used might vary as much as Io days "under identical conditions," but that the same variety might vary by as many as 9 days from year to year (Bailey and Bailey I 982, 35-36).

In other experiments, the growing season of Southwestern blue corn was I I 5-120 days (New Mexico State Univ., Dept. of Agric., Div. of Marketing and Development, n.d.). Pima corn planted at Tucson on March I I required 95 days to harvest; Papago corn in the same area required 73 days from July 24 when it was planted; Mojave Desert Flour corn, planted July i7 near Tucson, took 93 days; and Hopi Sweet corn, planted May 29, was ready to harvest in 83 days (Southwest Traditional Crop Conservancy 1982, I6).

Kirkby's (1973) data from the Etla Valley of Oaxaca, Mexico, suggest that varietal adaptation may be a critical factor in growing season requirements (see also Gillespie 1985, I 8). There, four varieties require 3, 4 to 5, and 6 months for maturation, and "corn in each area is so specialized that it is said that seed from the Etla Valley cannot be grown successfully in the Tlacolula Valley" (1973, 
57). In a letter to the Huschers $(1943,47)$, Alvin Kezer, chief agronomist at the Colorado State College of Agriculture Experiment Station, reported that "There are some native flint-like corns that can be grown in the San Luis Valley at 8,000 feet. They are very small corns and very low producers. ... [I]t is quite possible that ... some of these very short-season, flinty corns constituted a very definite part of food production for the Indians. . . Even so, about 8,ooo feet is ... the approximate upper limit of their growth." Whether these flinty varieties were capable of reaching maturity at 8 ,ooo feet is not reported.

These data concerning growing season requirements of different varieties of corn bring us to a significant point. The success of maize varietal strains seems partly the result of adaptation to local climatological conditions. Where varieties were successfully adapted to local conditions, neither temperature nor precipitation were likely to have significantly affected successful maize cultivation in the late prehistoric Southwest. Reduced to the absurd, however, the argument must be that the presence of maize in the archaeological record, no matter how marginal environmentally the site locality, is de facto evidence for its local cultivation because of its adaptability to local environmental conditions. The circularity implicit in such an argument is disconcerting and precludes consideration of two strategies important to maize agriculturalists: the exchange of maize and the consumption of green corn.

\section{An Archaeological Example}

Historically and ethnographically, we know that maize was exchanged for seed corn replenishment to offset instances of crop failure and to provision Plains bison hunters, but archaeologists seem loathe to accept a significant role for the exchange of corn as a subsistence strategy in the prehistoric Southwest. A case in point is the discussion of maize remains from excavated sites in the Chimney Rock, Colorado, area (Eddy I974; Minnis and Ford 1974).

Sites in the Chimney Rock area range in elevation from about 6,600 to 7,600 feet. The annual average temperature is $44.6^{\circ} \mathrm{F}$, and temperatures may fall below freezing each month of the year. Annual precipitation, however, is nearly $\mathrm{I} 8$ inches. Lacking local temperature data, Eddy relied on the nearby stations at Ignacio and Pagosa Springs, which reported 105 and 75 frost-free days respectively. Based on similarities in elevation, topography, and the proximity of 
Chimney Rock to Pagosa Springs, he arrived at an "extrapolated" frost-free season of 80 days (Eddy I974, 70), with "occasional" crop loss expected.

Maize remains made up a significant portion of the recovered macrobotanical materials from the sites. Maize pollen, however, comprised less than o.I percent of all nonarboreal pollen from the excavated sites (Bugge and Schoenwetter 1974, 80, Table 33). Minnis and Ford (1974) reported that the 18 cobs were not "particularly small or distorted, and the row numbers seem not to be diminished." Neither nubbins, suckers, nor tiller stalks were present. They characterized the entire maize collection as a homogeneous lot, suggesting that its derivation was from a single microclimatic locality. They concluded that the Chimney Rock area, as suggested by the homogeneity of the maize samples, was "not climatically marginal for maize" (1974, 88).

The reader is left to infer that the maize recovered from the Chimney Rock sites was grown locally by the inhabitants. In spite of the obvious climatic adversity indicated by local conditions (albeit representative of the modern, not necessarily the prehistoric, climate), we must conclude that Chimney Rock maize was a highly specialized variety adapted to extremes of climatic variability and conditions. It can be argued, nevertheless, that homogeneity in the Chimney Rock collection does not preclude maize "purchase" by the inhabitants from a nonlocal (but homogeneous) source. Alternatively, the more suggestive evidence for local production (stalks, cobs, and cob fragments) may derive from the successful cultivation locally of a green or roasting ear crop.

Unfortunately, identification and/or descriptions of the characteristics that distinguish green from mature corn are absent in the archaeological literature, though several authors have recorded the presence of green corn in Southwestern sites. The Huschers (I943, 46-47l, for example, reported "clear evidence that the corn has been used green" from sites in the San Juan Mountains of western Colorado and from hogan sites on the Uncompahgre Plateau, but they provide no supporting evidence. Martin and Sharrock (1964, 175-76) claimed that much of the corn at Glen Canyon sites "was eaten green," as determined from the cobs, but they provided no descriptions. Cutler and Meyer $(1965$, I 42) remarked that shriveled kernels from Mesa Verde sites "often prove to be cooked green corn," again without explaining their observation. Physiologically, the mature stage of maize is expressed at the point of maximum dry weight, or 
30-35 percent moisture content. Presumably, the shriveled kernels reported by Cutler and Meyer reflect the higher moisture content of green corn that had been driven out by heat.

The Chimney Rock example is not meant to deny the possibility that maize was locally grown but rather to emphasize that its presence at a site located in an area climatically marginal for corn production is not necessarily proof that the crop was locally grown. Moreover, the harvest of an immature or green corn crop and its processing and consumption might produce the elements identified and described by Minnis and Ford from the Chimney Rock sites. Although some paleo-ethnobotanists seem able to distinguish between green and mature corn, the identifying attributes are not described in the archaeological literature.

\section{Growing Season Calculations}

While it is difficult to determine the growing season requirements of prehistoric maize, a high degree of variation in growing season length is likely to place corn production at risk (Tuan et al. I973, 8). To emphasize the variability in the frost-free season at elevations above 6,000 feet in the region considered here and therefore the potential risk to achieving a mature crop of corn, I examined U.S. Weather Bureau figures for the last spring "killing frost" and the earliest fall "killing frost" to I93 I at selected stations in northern and northeastern New Mexico.

Frost data from stations appropriate for this study in terms of latitude and elevation are recorded in the 1932 edition of the Climatic Summary of the United States (USDA, Weather Bureau I 932). Dates for each recorded year document $(\mathrm{I})$ the last spring killing frost, (2) the latest occurrence of $32^{\circ} \mathrm{F}$ in the spring, (3) the first fall killing frost, and $(4)$ the earliest occurrence of $32^{\circ} \mathrm{F}$ in the fall. The number of "growing season" days listed for each station was calculated by the Weather Bureau as the number of days between the last and first killing frosts of the year. The temperatures for those frost days are not provided, but the dates frequently coincide with the occurrence of $32^{\circ} \mathrm{F}$ minima for the station. Just as often, however, the growing season is longer than the number of days between $32^{\circ} \mathrm{F}$ minima. For example, in Santa Fe in 1890 , the last killing frost occurred on April 9 , but the latest occurrence of $32^{\circ} \mathrm{F}$ was not until April 25; similarly, in $\mathrm{I} 898$ in Santa $\mathrm{Fe}$, the first killing frost in fall occurred on October I7, but the earliest day with $32^{\circ} \mathrm{F}$ was September I 2 . 
In deciding which calculation is most useful for understanding constraints on corn growth, we should keep in mind Tuan and colleagues' caution that the instrumentation used at weather stations does not record ground surface or soil temperatures:

[T] he frost-free season is a very liberal measure of the period available for plant growth. Growth does not normally happen below $4 \mathrm{O}-4 \mathrm{I}^{\circ} \mathrm{F}$, and the season with temperatures above this level is, of course, shorter than the frost-free season. There is further complication, in that the temperatures upon which the frost-free season is based are normally measured six feet above the ground in a standard meteorological instrument shelter. Frost occurs closer to the ground, where many crops grow, later in spring and earlier in fall, than at the six-foot level. (Tuan et al. 1973, 79)

Assuming that there may be as many as $2-3^{\circ} \mathrm{F}$ difference between 0 and 6 feet and that maize does not germinate below $25-28^{\circ} \mathrm{F}$ (nor will it grow much below $4 \mathrm{O}-4 \mathrm{I}^{\circ} \mathrm{F}$ ), I have for convenience used the $32^{\circ} \mathrm{F}$ minima as indicative of the closest approximation to a killing frost provided in the Weather Bureau data cited above.

The mean number of days between the last spring and first fall $32^{\circ}$ minima was determined for each station shown in Table 5. I. These are compared with the number of days indicated by the Weather $\mathrm{Bu}$ reau as the growing season, that is, the number of days between killing frosts. The difference between the two periods is shown in the last column of that table. For example, at Tajique, the number of days between minima in I920 was I 33 days, in I929, 13 I days, and so on; the II-year mean is 125 days. In this case there is a 9-day difference between the mean number of growing season days according to the Weather Bureau and the mean number of days between recorded $32^{\circ} \mathrm{F}$ minima over a period of I I years. Similar figures are recorded for each station. The mean number of days difference for all stations combined is $\mathbf{I} 2$ days (see also Gillespie I 985, I8, which reports that a recalculation of U.S. Weather Bureau data from Chaco Canyon resulted in a mean difference of 13 days).

Pursuing this further, the median days on which the last spring and first fall $32^{\circ} \mathrm{F}$ reading occurred (over $N$ yrs./station) were calculated. These are presented in Table 5.2 and are again contrasted with the Weather Bureau growing season length. At Tajique again, over a period of I I recorded years the median spring minimum $\left(32^{\circ} \mathrm{F}\right)$ is May 23, and the median fall minimum is September 26, signifying a frost-free period of only I 26 days (as opposed to the I 34-day growing season indicated by the Weather Bureau). Using this method, for all 
stations combined the mean number of days' difference between the Weather Bureau's growing season and the median frost-free period is I 5.3 days. Overall, then, the Weather Bureau calculations most likely overestimate growing season lengths for these stations.

The potential significance of these figures may be mitigated by the fact that they are derived from modern records /Gillespie 1985, I8). They are important, nevertheless, for assessing the relative degree of risk to farmers at different locations. Although the figures are based on modern data, they should be considered suggestive of the uncertainty faced in the expectation of a "normal" growing season, and therefore of a mature maize crop, by the prehistoric farmers in these areas.

Table 5.1. Comparison of the Number of Days Recorded for Community "Growing Season" by the U.S. Weather Bureau (1932) and the Number of Days Recorded Between the Last Spring $32^{\circ} \mathrm{F}$ and First Fall $32^{\circ}$ F Dates

\begin{tabular}{lcccr}
\hline & $\begin{array}{c}\text { Elevation } \\
\text { (Years } \\
\text { Recorded) }\end{array}$ & $\begin{array}{c}\text { Growing } \\
\text { Season } \\
\text { (in Days) }\end{array}$ & $\begin{array}{c}\text { Days Between } \\
\text { Last Spring } \\
\text { and First } \\
\text { Fall 32 }\end{array}$ & Difference \\
\hline Mountainair & $6,475(20)$ & 154 & 141 & 13 \\
Tajique & $7,100(1)$ & 134 & 125 & 9 \\
Santa Fe & $7,013(55)$ & 154 & 165 & 13 \\
Espanola & $5,590(27)$ & 164 & 149 & 15 \\
Taos & $6,983(320)$ & 145 & 130 & 15 \\
Sunshine Valley & $7,500(15)$ & 125 & 117 & 8 \\
Tres Piedras & $8,076(23)$ & 112 & 100 & 12 \\
Las Vegas & $6,400(37)$ & 154 & 145 & 2 \\
Fort Union & $6,835(23)$ & 141 & 128 & 22 \\
Des Moines & $6,622(14)$ & 146 & 144 & 11 \\
Levy & $6,252(17)$ & 146 & 124 & 15 \\
Dawson & $6,395(18)$ & 160 & 149 & 13 \\
Miami & $6,000(18)$ & 149 & 134 & 12 \\
Cimarron & $6,427(27)$ & 153 & 140 & 12 \\
Raton & $6,660(31)$ & 147 & 135 & 109 \\
Vermejo Park & $7,600(16)$ & 121 & & \\
\hline
\end{tabular}

${ }^{\text {a}}$ Mean: 12 days. 
Table 5.2. Comparison of the Number of Days in the U.S. Weather Bureau "Growing Season" and the Number of Days Between the Median Spring and Fall $32^{\circ} \mathrm{F}$ Minima

\begin{tabular}{lccc}
\hline & $\begin{array}{c}\text { Growing } \\
\text { Season } \\
\text { Days }\end{array}$ & $\begin{array}{c}\text { Sonth and Day of Median } \\
\text { and Days Between } \\
\text { Median } 32^{\circ} \text { Minima }\end{array}$ & Difference $^{\text {a }}$ \\
\hline Mountainair & 154 & $5 / 1-9 / 30(135)$ & 19 \\
Tajique & 134 & $5 / 23-9 / 26(126)$ & 8 \\
Santa Fe & 178 & $5 / 8-10 / 9(154)$ & 24 \\
Espanola & 164 & $5 / 16-10 / 5(143)$ & 21 \\
Taos & 145 & $5 / 1-9 / 16(121)$ & 24 \\
Sunshine Valley & 125 & $5 / 25-9 / 30(128)$ & -3 \\
Tres Piedras & 112 & $6 / 4-9 / 15(103)$ & 9 \\
Las Vegas & 154 & $5 / 9-10 / 9(152)$ & 21 \\
Fort Union & 141 & $5 / 24-9 / 21(120)$ & 31 \\
Des Moines & 146 & $5 / 17-9 / 5(115)$ & 16 \\
Levy & 146 & $5 / 17-9 / 26(130)$ & 13 \\
Dawson & 160 & $5 / 15-10 / 9(147)$ & 20 \\
Miami & 149 & $5 / 1-9 / 25(129)$ & 15 \\
Cimarron & 153 & $5 / 14-9 / 30(138)$ & 12 \\
Raton & 147 & $5 / 1-9 / 24(129)$ & 11 \\
Vermejo Park & 121 & $6 / 3-9 / 21(110)$ & \\
\hline
\end{tabular}

${ }^{\mathrm{a}}$ Mean: 15 days.

As discussed in the previous section, the environmental constraints on Southwestern maize varieties are difficult to determine from the literature. I would argue, however, that given the risks involved in corn production and the frequent references to the use of green cornboth from archaeological sites and in the ethnographic record-immature corn was harvested more often than not in areas above 6,000 feet and in more northerly latitudes. Ethnographic accounts in particular contain substantial information on the use of green corn.

\section{GREEN CORN AND SEED CORN}

Castetter and Bell, in documenting the use of green corn among the lower Colorado River groups, noted that at least half of the crop "was 
eaten as green corn. As a matter of fact, when maize reached the roasting ear stage, the Indians ate little else, and they ate it three times a day" (Castetter and Bell I95 I, 68). Farther east, Spanish accounts of eighteenth-century expeditions onto the southern Plains via the Sangre de Cristo Mountains suggest that the harvest and consumption of green corn by Athapaskan residents of those regions may have played a significant role in subsistence (see also Huscher and Huscher 1943, 48). In 1706, Ulibarri and his men were given "much bison meat and roasting ears of Indian corn" in the vicinity of Cuartelejo (in western Kansas), as well as "sacks of corn" during the month of July (Thomas I 935, 68-73). Moving through the Cimarron and Vermejo Creek area in 1719 , Valverde Cossio and his men were given "many ears of green corn" in September. Plans for an expedition to the Faraon Apaches in 1715 considered advice about the appropriate time of the year for encountering those groups. One opinion indicated that the best time

is in the middle of August. . . [A]t this time they are shaking out the grains from the ears of corn. Having finished doing this and having buried it beneath the soil, they all go on a hunt for buffalo where they maintain themselves until they return to sow which is at the end of April or the beginning of May. There they remain until they cut it. They will not find them in any other manner since they live where there is hunting and then invade this province lof New Mexicol for corn when they need it. (Thomas I935, 8I, emphasis added)

One Spaniard, however, expressed doubt concerning the information given, saying that "although the Indians say that in the middle of August the Apaches reap their maize, it appears to him that this is not possible having sowed it at the end of April. But even reaping during August must require more than a month for drying it" (Thomas I935, 84). He assumed, of course, that the crops in question were mature, rather than green, corn, which would be suitable for immediate boiling or roasting, drying, and subsequent storage.

Green corn was picked by the Hidatsa in the northern Plains "about the end of the first week in August" (Wilson I9 17, 37). It was boiled after shelling, or the ears were roasted in underground pits (as at Zuni; see Cushing 1920). A second planting of maize specifically for green corn was also the usual practice among the Hidatsa, "but it often got caught by the frost" (Wilson I 117,37 ). This second planting was made in June. Wilson's informant noted that it required, after boiling, only four days to dry prior to storage in sacks for the winter in 
cache pits (Wilson I9 I7, 4I, 97). The similarity to the Faraon Apache description is striking, and a "roasting pit," excavated at a seventeenth-century Apache site near Ocate, New Mexico/Gunnerson 1969, 251, may reflect similar practices by Athapaskans closer to the eastern Pueblo frontier.

Having completed the green corn harvest and preparations for the hunt, the Athapaskans' need to replenish seed corn for the next year's sowing and to obtain carbohydrates to carry them through the lean winter months was apparently easily met by "invading" the eastern pueblos with an abundance of bison products to exchange for the necessary mature corn-and perhaps seed corn as well. Fall is clearly indicated as the period when Apachean groups were most visible among the eastern pueblos, exchanging bison products for maize and other items (Spielmann I982, I28-13 I).

Maize horticulture was also practiced to some extent by the Weminuche Utes, who used dry-farming techniques. The exploration parties of Jackson $(1876,18)$ and Hayden $(1877,43)$ described the use of green corn among these people. Gifford (1940, 102) reported that the southern Utes used their corn green, "retaining only two ears dry for seed purposes" (cited in Huscher and Huscher 1 943, 47). Ford (1972a, 3 I) noted that the Tewa pueblos exchanged corn with the Utes for products of the hunt (see also Huscher and Huscher 1943, 47).

Purportedly in reference to San Juan Pueblo, Robbins and colleagues $(1916,94)$ cite a passage from Torquemada's Monarchia Indiana (ca. I60I) which claimed that

As soon as the ears of Maize have come to be in milk, they gather many of them.... and when the Ears are pretty well hardened ... they gather many of them, and, after parching or roasting them, set them in the sun; and when they are dried, they store them.... The rest of the Ears, which are left growing, they allow to ripen entirely, to store them, in the form of Maize, ready for setting, and for sowing at the proper season. They do all of this, because the frosts begin very early, and the harvest is in much danger of being lost; and so this [is the] manner of gathering their food, so as to enjoy some of it before it be all frozen and lost to them.

More recently, Hill $(1982,31)$ noted that at Santa Clara they sowed and harvested two maize crops. Presumably, the first one was for green corn, which was "available for eating from the latter part of July through August." The main crop was not harvested until September. Two maize crops, one specifically for green corn and planted in mid-April, are reported among the Hopi (Bradfield I 97 I, 6). In both 
cases the green corn ears were treated and stored for winter use.

Access to seed corn, through preservation from mature crops and/ or exchange for seed, is particularly critical for those groups who harvest the majority of their corn in the immature state. Data concerning seed corn in the Pueblo Southwest are scarce, but comments pertaining to other maize specialists throughout the Greater Southwest make it clear that the preservation and exchange of seed corn from one year to the next were of frequent and critical concern.

Among the Tepehuan and Pima Bajo (Pennington 1969, 1980), for example, the frequent lack of seed for planting, particularly corn, resulted from partial or complete crop failure, consumption of seed corn in the face of hunger, and/or the use of seed corn in manufacturing large amounts of tesguino. Among the Pima Bajo, Pennington noted, "it is claimed that an average of one-fourth of the stored corn is damaged by moisture or predators" (Pennington 1980, I6I). He also noted the dependence of the Tarahumara on elotes (green corn) as a staple in the late summer, which precluded "storage of an amount of corn sufficient to last until the next planting" $(1963,53)$. The replenishment of seed corn was thus of critical concern.

In the Pueblo area, Bradfield (I 97 I, 5) stated that as much as 7.5 percent of Hopi seed corn was imported from outside sources. Neither the sources nor the conditions under which these circumstances arose are identified, but partial or complete crop failure would certainly necessitate some seed importation in addition to creating severe winter food stress. With regard to seed corn, at least one Santa Clara informant imported a red strain from Jemez and intended to obtain white corn from Taos "because it is very cold there, and their corn ought to ripen early [at Santa Clara]" (Robbins et al. I916, 85). Improvident families at Cochiti were referred to as " children of the cacique,' the idea being that the cacique's store of corn constituted a seed reserve in case of failure elsewhere in the pueblo" (Lange I 959,84$)$.

The actual quantity of seed corn necessary for a family is recorded for the Hidatsa. Families often had to purchase seed corn in the spring. The price was one tanned buffalo hide for one string of braided seed corn (Wilson 1917,48 ). The number of seed ears per braid is not mentioned, but braided corn carried to the Hidatsa villages for further treatment and processing contained 54 to 57 ears (Wilson I9I7, 45). The informant noted that "five braided strings of soft 
white, and about thirty ears of soft yellow" corn were needed for seed (Wilson I 917, 47).

\section{CONCLUDING COMMENTS}

In summarizing Western Apache subsistence, Minnis (1985, 3 I6) remarked that

agriculture may have represented an efficient and inexpensive buffer against the failure of important naturally available foodstuffs. Cultivation was inexpensive because it did not conflict with other food acquisition strategies, and the time spent in farming - a month or two-may not have represented major energy expenditure. Therefore, the patterns of Western Apache agriculture may have been a relatively inexpensive and reliable subsistence activity which did not interfere with the traditional cycle of resource exploitation.

The adoption of a similar strategy by indigenous Rio Grande populations during Basketmaker and early Pueblo times may also have been an inexpensive and reliable subsistence pursuit because it required little labor and did not result in significant scheduling conflicts. Generally successful yields of matured crops in the valley of the Rio Grande (at elevations below about 6,00o feet) may have encouraged increased reliance on horticulture. However, dependency on maize may not have occurred in the Rio Grande area until substantially later, following a dramatic population increase (Snow I 990). Prior to about A.D. I200-I300, populations in the higher elevations along the valley continued to exhibit a more dispersed and mobile settlement pattern suggestive of mixed hunting, gathering, and horticultural subsistence.

This pattern seemingly continued until about the thirteenth century along the Sangre de Cristos into the area of southeastern and southern Colorado described by Eighmy $(1984,37)$. There was, however, greater emphasis on hunting and gathering as one moves northerly and northeasterly, that is, along the same transect occupied by part-time horticulturalists (Apaches) a scant 400 years or so later. In those more northerly latitudes and correspondingly higher elevations, a shorter and more variable growing season probably decreased the reliability of horticultural yields. The diversification of planting locations and variations in sowing schedules may have been used in these more northerly areas, as has been documented ethnographic- 
ally among the Pueblos (Cushing I920; Hack r942; Bradfield 1971; Hill I982). Minnis ( 1985 ) suggests that such diversification may not have been expensive and therefore may not have been inimical to a highly mobile hunter-gatherer lifestyle such as that of the Western Apache. To offset any expenses inherent in such intensification (that is, in the adoption of horticulture) and subsequent diversification and variation in field and sowing scheduling, reliance on a nearly "fail-safe" roasting ear, or green corn, harvest and the development of intercommunity ties to facilitate the "purchase" of seed and surplus mature corn are logical alternatives. While diversification in field location and sowing schedules may increase the potential for a mature corn crop at one or more locations above about 6,00o feet, from one year to the next the only potentially fail-safe crop can be expected to have been harvested immature. The intensification of intercommunity ties at the interhousehold level, or between trading partners, in order to obtain both next year's seed and sufficient carbohydrates for winter in exchange for high-elevation produce such as meat may well have preconditioned the protein-for-carbohydrate exchange modeled by Spielmann (1982, I983) for the protohistoric Plains-Pueblo system. 


\title{
6. Texas Panhandle-Pueblo Interactions from the Thirteenth Through the Sixteenth Century
}

\author{
CHRISTOPHER LINTZ
}

The present chapter addresses the nature of late prehistoric PlainsPueblo interaction, and the mechanisms for sustaining this interaction by focusing on one Plains Village group that resided in the Texas Panhandle from the early thirteenth through the sixteenth century. This group, known as the Antelope Creek phase, was selected because of its proximity to the Southwest and the extent of information available about Southwestern materials recovered at Antelope Creek phase sites. In addition, the chronological position of the manifestation precedes the protohistoric cultural manifestations that are the focus of several other chapters in this volume (Fig. 6.I). Other recently defined prehistoric manifestations along the eastern edge of the Texas Panhandle are excluded from consideration. The Buried City complex (Hughes and Hughes-Jones I 987) and the Zimms complex (Flynn 1984, 1986) contain significant differences in ceramics, lithic resources, and some tool forms, even though they share strong similarities in general architectural patterns with the Antelope Creek phase.

The information presented in this study is based almost exclusively on compilations from field notes, manuscripts, and publications about Antelope Creek phase sites since the I920s. Little of the information has been supplemented by a reanalysis of excavated materials curated in Texas, Oklahoma, or elsewhere. Thus, certain contextual limitations are inherent in the present approach, and the conclusions must be regarded as working hypotheses. A brief synopsis of the Antelope Creek adaptation provides the context for interpreting the interaction with Southwestern groups. Subsequent sections examine the nature of this interaction and the impact of exchange 
on the Antelope Creek phase. A model of late prehistoric cultural interaction is proposed, and changes in the exchange system that occurred during the sixteenth century are noted.

\section{THE ANTELOPE CREEK PHASE CULTURAL CONTEXT}

Contrary to claims made in early studies (Studer 193 I; Krieger I946; Spencer and Jennings 1965), the Antelope Creek phase reflects an adaptation to the short-grass region in the Texas and Oklahoma panhandles by people who were neither biologically nor culturally derived from the Southwest (Patterson 1975; McWilliams and Johnson I979). The phase represents the southwesternmost expression of the Plains Village pattern, which developed rapidly about A.D. I 200 and lasted until perhaps I 500 . The duration of the phase generally coincides with xeric climatic conditions throughout the region (Lintz I986a). That Antelope Creek participated in the Plains Village pattern is reflected in the occurrence of such distinctive traits as:

(I) a subsistence based about equally on hunting (primarily bison), foraging, and horticulture,

(2) semi-permanent villages;

(3) villages located adjacent to larger floodplains;

(4) semi-subterranean rectangular lodges with predominantly an eastward extended entrance and a four-post roof support system surrounding a central hearth;

(5) cache pits in and between houses;

(6) grit-tempered, cordmarked pottery that is rarely decorated;

(7) scrapers and small, light, triangular, unnotched and sidenotched projectile points;

(8) bison scapula hoes and tibia digging-stick tips;

(9) notched bison rib "rasps" (Lehmer I954, I 39-I 40).

Unlike Plains Village manifestations along the eastern prairieplains border, Antelope Creek differs in the frequent use of masonry architecture, the presence of distinctive central floor channels used to segregate interior work areas, the occasional presence of raised platforms, and sometimes the occurrence of large, contiguous room blocks.

Direct paleoenvironmental information on the Texas Panhandle between A.D. I000 and I600 is unavailable, but present evidence provided from geomorphological, malacological, and palynological 


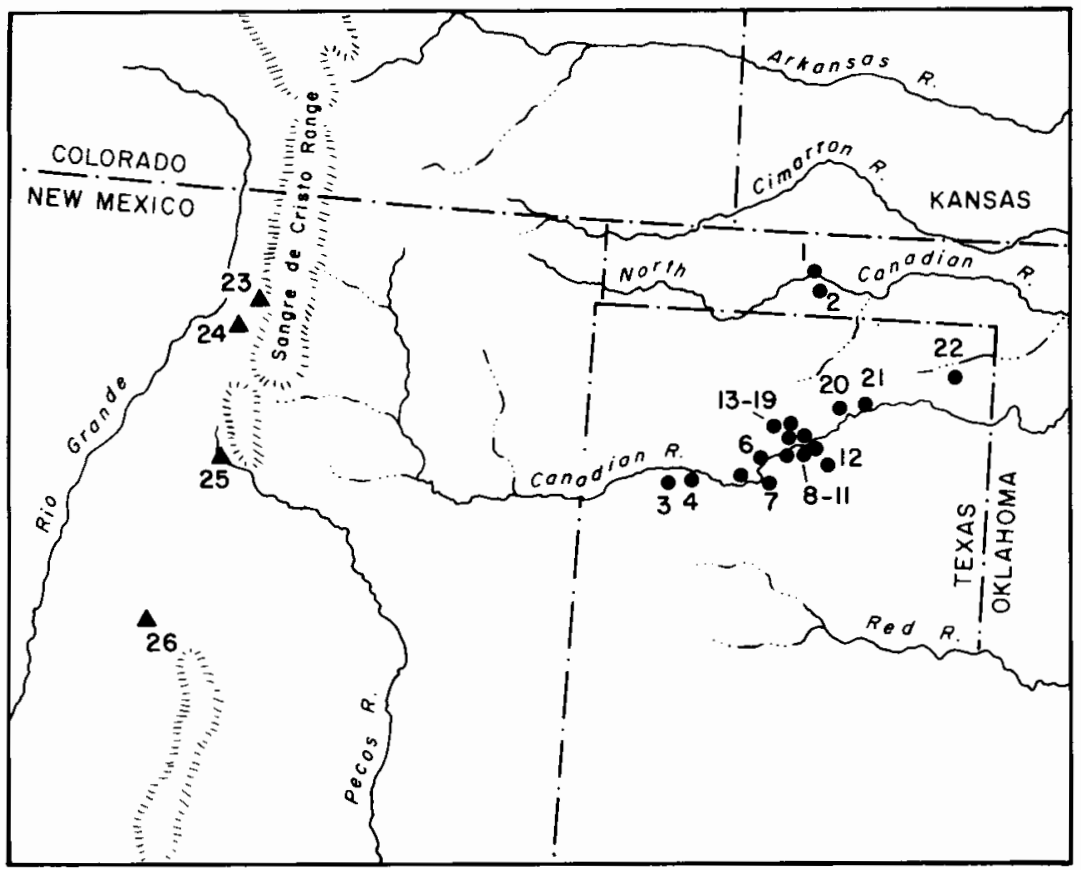

Antelope Creek Phase Sites

1 McGrath site, Oklahoma

2 Stamper site, Oklahoma

3 Landergin Mesa, Texas

4 Saddleback ruin, Texas

5 Chimney Rock ruin, Texas

6 Footprint site, Texas

7 Coetas Creek ruin, Texas

8 Alibates Ruin 28, Texas

9 Turkey Creek ruin, Texas

10 Roper site, Texas

11 Pickett site, Texas

Select Pueblo Sites

23 Taos, New Mexico

24 Picurís, New Mexico
12 Antelope Creek Ruins $22 \& 24$, Texas

13 Floyd Ranch ruin, Texas

14 CR-1a ruin, Texas

15 Ozier ruin, Texas

16 Big Blue ruin, Texas

17 Spring Canyon ruin, Texas

18 Arrowhead Peak ruin. Texas

19 Black Dog Village. Texas

20 Mathews Ranch ruin. Texas

21 McGarraugh Ranch ruin, Texas

22 Handley ruins (Buried City Complex)

25 Pecos, New Mexico

26 Gran Quivira, New Mexico

FIGURE 6.t. Distribution of the Antelope Creek sites discussed in the text. 
studies in southeastern Colorado, western Oklahoma, and eastern New Mexico all support a general trend toward xeric conditions between A.D. I 100 and I 300 (S. Hall 1982; Science Applications I982; Lintz and Hall 1983; Speth I983; Hall and Lintz 1984; Schuldenrein I 985 ; Ferring 1986). Even though specific conditions are unknown for the Texas Panhandle, the same general drying patterns are believed to have occurred throughout the central and southern Plains. Quite likely the Texas Panhandle region was experiencing a series of droughts of unknown intensity and periodicity throughout the Antelope Creek phase. Variability in the localized precipitation patterns across the Plains impacts the patchy distribution of plant and animal resources and strains the predictability of economic success in hunting and/or horticulture. The resultant short- and long-term variation in resource availability at any given time lies at the heart of late prehistoric regional exchange and interaction. It is hypothesized that trade relationships provided access to food resources over a broader area than maintained and controlled by a single ethnic entity (Lintz I986a).

How is it, then, that the Antelope Creek phase developed and flourished during this period of presumed precipitation instability in a region that today receives only 20 inches $(51 \mathrm{~mm}$ ) of annual rain? The single critical resource unique to the short-grass region on the southern Plains, and one that partially offsets climatic uncertainty, is the huge subsurface fossil water reserves of the Ogallala aquifer. Recent studies of this resource have shown that the fossil water reserves overlying the Alibates Formation may have been as much as $25 \mathrm{~m}$ thick prior to pump irrigation (Cronin 1969; Luckey et al. I98I). Thus, with the onset of xeric conditions around A.D. I250, water in the Canadian and other major rivers may have begun to decline, but during short droughts, sweet spring water would have been available in the lateral tributaries before it submerged in the sandy substratum of the river valleys. General drought conditions across the southern Plains would have enhanced the environmental aspects of the river valleys in the Texas Panhandle that were sought by late prehistoric Plains hunter-gatherer-horticulturalists from adjacent regions.

An analysis of Antelope Creek cultural variability based on information from 28 major excavated architectural sites in the Canadian River valley has recently been completed (Lintz I 986a). These sites do not represent the full range of Antelope Creek activity loci, but 
they do represent the locations to which resources from ancillary sites would have been returned. Chronological control provided by 56 radiocarbon and 4 archaeomagnetic samples, and ceramic crossdating of 19 types with Pueblo sequences permitted the delineation of two temporally distinct subphases.

The Early Subphase (A.D. I 200-1350) is typified by (I) a hierarchy of architectural site types involving hamlets (multifamily residences), homesteads (single-family residences), and subhomesteads (nonresidences or farmsteads); (2) settlement systems that place the farmsteads near the Canadian River, while hamlets most often occur adjacent to springs in high settings along lateral tributaries; $|3|$ the predominance of contiguous, multiroom architecture at hamlets and homesteads; $(4)$ the relatively rare occurrence of Southwestern trade goods; and (5) little evidence of hostilities as reflected in the selective burning of room types or the presence of unburied or presumably murdered individuals. In contrast, trends delineated during the Late Subphase (A.D. I 350-I 500) include (I) the disappearance of the subhomestead or farmstead; (2) the reorientation of settlements along high and low tributary settings of the Canadian River valley; (3) the predominance of isolated room structures; (4) a marked increase in the quantity and variety of Southwestern trade goods; and (5) occasional evidence of hostilities as reflected in butchered human remains, the presence of suspected nonindigenous trophy skulls, and healed arrow wounds on skeletal remains at the Footprint site (Patterson 1975; Green 1986) and possibly the Handley ruins (Eyerly 1907, 222; Moorehead 1931).

These changes have been interpreted as reflecting various strategies employed to utilize the local environment more efficiently and to tap or control resources in adjacent regions. The abandonment of the farmsteads and the shift in settlements away from the Canadian River reflect settlement reorientation toward the Ogallala aquifer springs and the use of arable plots closer to the hamlets and homesteads. The shift from contiguous to isolated room structures was thought to indicate some kind of breakdown in social cohesion (Lintz r986a), but this change more likely signals increased mobility and shorter duration of settlement. The trade-violence trends reflect mechanisms to expand resource acquisition or control over resources in or adjacent to the region. Taken together, these trends are regarded as options employed in an attempt to retain the Plains Village adaptation under the uncertainties imposed by resource instability. This, 
then, serves as a contextual background for examining late prehistoric regional interaction.

\section{THE NATURE OF THE INTERACTION}

The scale of interaction involving Antelope Creek populations is not limited to relations with Pueblo groups. Nonlocal materials such as Crockett Curvilinear incised sherds at Antelope Creek Ruin 24 and collared-rim cordmarked sherds at the Roper and Turkey Creek sites (Baker and Baker 1939, 23; Green 1986; Dumas and Dumas n.d.), reflect some degree of interaction with the Caddoan area and other Plains groups. In general, interaction with adjacent Plains Village groups may have been much greater than presently documented, since pottery and other materials indicative of such interaction are difficult to identify for groups with similar assemblages. The obvious differences in ceramics, jewelry, and other goods from the Pueblo area are much more easily detectable. Thus Plains-Pueblo relationships are often the focus of analysis. Plains-Pueblo interaction, however, must be regarded as part of a larger phenomenon involving many groups across the southern Plains and adjacent areas (see Baugh and Wilcox, this volume).

The evolution of Plains-Pueblo interaction is reflected in the kinds of materials that were traded, and in changes in the intensity of exchange between the Early and Late Antelope Creek subphases. Although little emphasis is placed on Plains materials at Pueblo sites, suffice it to say that the dominant preservable products from the Plains found in Pueblo sites include Alibates agate', elbow pipes, occasional cordmarked pottery, and a wide range of bone tools, including bison metapodial fleshers or tibia digging-stick tips, split rib side scrapers, cancellous bone grainers, sickle-shaped toothed implements, antler rubbing tools, beamers, shaft wrenches, and perhaps awls (Krieger I946, 62; Snow I98I, 358-365; Bronitsky 1982, 67; Spielmann I982, I983). Presumably these items were accompanied by perishable products such as bison hides, Osage orange wood for bows, salt, tobacco, and foodstuffs.

Among Antelope Creek sites, tangible Pueblo materials occur in five forms: ceramics, obsidian, stone and shell jewelry, pipes, and perhaps exotic materials. These Pueblo trade goods must be examined further to delineate the nature of the contact and exchange. Ceramics are represented by at least 465 sherds attributed to Pueblo 
sources from predominantly I 5 hamlet sites. Only IO4 of these sherds have been identified. At least 19 identifiable Pueblo types or styles have been found in at least eleven Antelope Creek phase sites in Texas and Oklahoma. Five other sites have yielded unidentifiable "Pueblo" sherds (Table 6.I). Most types are widely distributed, and their actual occurrence may reflect little more than available goods at "portal" or gateway pueblos along passes to the Plains. Twelve of the 19 ceramic types are specifically derived from the northern Pueblos. In descending order, ceramics are also derived from the western Pueblos (five types) and southern Pueblos (two types). This high incidence of northern Pueblo ceramic goods suggests that Antelope Creek phase groups had limited access to or contact with select Pueblo areas. Some vessels from the southern and western Pueblos may be trade items that passed through the northern Pueblo villages. In the Antelope Creek region, Southwestern ceramics predominantly occur at hamlet sites, very rarely at single-family homestead sites, and they have yet to be reported from subhomestead sites in the Canadian and North Canadian River areas. This distribution of trade vessels may indicate the specialized functions of the subhomesteads in the Antelope Creek phase settlement hierarchy.

Obsidian is fairly ubiquitous across the various site types. To date, $\mathrm{x}$-ray fluorescence analysis to identify specific obsidian sources has been conducted only on specimens from three Antelope Creek sites in Texas. Samples from Tarbox and McGarraugh Ranch have been tentatively identified as being derived from the Valles Caldera (Mitchell et al. I980). Six samples from various contexts at Landergin Mesa (Baugh and Nelson n.d.) were determined to be from the Obsidian Ridge locality in the Jemez Mountains. Overall, obsidian occurs in relative abundance at some sites. In excess of I02 obsidian flakes and tools were recovered from a $42 \mathrm{~m}^{2}$ excavation area at Landergin Mesa during the 1984 season (Lintz 1990), and 4, 132 obsidian pieces were recovered from a $2,898 \mathrm{~m}^{2}$ portion of Alibates Ruin 28 (Unit II) by WPA crews (Lintz 1986b).

Jewelry obtained from the Southwest includes turquoise beads and pendants, marine shell disc and ground-top Olivella shell beads, conus shell tinklers, conch shell gorgets, and pendants. Other items include soapstone and red stone beads. Most objects were recovered from homesteads and hamlet sites and obviously originated far from the portal pueblos.

Pueblo pipes are represented by a series of clay and stone tubular 
Table 6.1. Southwestern Ceramics Recovered from Antelope Creek Sites

\begin{tabular}{|c|c|c|c|}
\hline Ceramic Type & Number $^{a}$ & $\begin{array}{l}\text { Antelope Creek } \\
\text { Site }\end{array}$ & Reference \\
\hline \multicolumn{4}{|l|}{ Northern Pueblo Derivation } \\
\hline \multirow{3}{*}{ Santa Fe Black-on-white } & 1 & McGrath & Lintz 1976, 58 \\
\hline & 1 & Floyd Ranch & Crabb 1968 \\
\hline & 9 & CR-1a & Crabb 1968 \\
\hline \multirow[t]{2}{*}{ Wiyo Black-on-white } & 1 & Floyd Ranch & Crabb 1968 \\
\hline & 8 & CR-1a & Crabb 1968 \\
\hline \multirow[t]{2}{*}{ Galisteo Black-on-white } & 2 & Ozier & Snow n.d.; Crabb 1968 \\
\hline & 13 & CR-1a & Crabb 1968 \\
\hline \multirow[t]{2}{*}{ Rowe Black-on-white } & 3 & Stamper & Watson 1950 \\
\hline & 19 & CR-la & Crabb 1968 \\
\hline Abiquiu Black-on-gray & $2+$ & Saddleback Ruin & Holden 1934; Crabb 1968 \\
\hline \multirow[t]{5}{*}{ Agua Fria Glaze Red } & $x^{1}$ & Alibates 28 & Hobbs 1941; Krieger 1946, 47; Crabb 1968 \\
\hline & $\mathbf{x}$ & Antelope Creek 22 & Hobbs 1941; Crabb 1968 \\
\hline & $4+$ & Saddleback Ruin & Holden 1934; Crabb 1968 \\
\hline & 5 & Chicken Creek & Schmidt-Couzzourt 1983 \\
\hline & 2 & Big Blue I & Crabb 1968; Couzzourt and Schmidt-Couzzourt 198 \\
\hline \multirow[t]{7}{*}{ Cieneguilla Glaze Yellow } & 1 & Ozier & Snow n.d. \\
\hline & 1 & Floyd Ranch & Crabb 1968 \\
\hline & 10 & Big Blue I & Crabb 1968; Couzzourt and Schmidt-Couzzourt 198 \\
\hline & 1 & Saddleback Ruin & Crabb 1968 \\
\hline & $\mathbf{x}$ & Alibates 28 & Crabb 1968 \\
\hline & $\mathbf{x}$ & Antelope Creek 22 & Crabb 1968 \\
\hline & $\mathbf{x}$ & Landergin Mesa & Wulfkuhle 1984 \\
\hline
\end{tabular}




\begin{tabular}{|c|c|c|c|}
\hline San Clemente Glaze Polychrome & 2 & Ozier & Snow n.d. \\
\hline \multirow[t]{3}{*}{ Largo Glaze Yellow } & 1 & Ozier & Crabb 1968 \\
\hline & 1 & Isolated find & Crabb 1968 \\
\hline & $\mathrm{x}$ & Landergin Mesa & Wulfkuhle 1984 \\
\hline Largo Glaze Polychrome & 1 & Ozier & Crabb 1968 \\
\hline Kuaua Glaze Polychrome & 3 & Saddleback Ruin & Crabb 1968 \\
\hline San Lazaro Glaze Polychrome & 1 & Ozier & Snow n.d. \\
\hline \multicolumn{4}{|l|}{ Western Pueblo Derivation } \\
\hline Kowina Black-on-white & 1 & Isolated find & Crabb 1968 \\
\hline Jeddito Yellow ware & 1 & Ozier & Snow n.d. \\
\hline \multirow[t]{2}{*}{ St. Johns Polychrome } & $\mathbf{x}$ & Alibates 28 & Hobbs 1941; Crabb 1968 \\
\hline & $\mathbf{x}$ & Antelope Creek 22 & Hobbs 1941; Crabb 1968 \\
\hline Heshotauthla Polychrome & 7 & Floyd Ranch & Crabb 1968 \\
\hline Little Colorado Glaze I & 2 & Antelope Creek 22 & Lowrey 1932 \\
\hline \multicolumn{4}{|l|}{ Southern Pueblo Derivation } \\
\hline Chupadero Black-on-white & 1 & Floyd Ranch & Crabb 1968 \\
\hline \multirow[t]{2}{*}{ Lincoln Black-on-red } & $\mathbf{x}$ & Alibates 28 & Krieger 1946, 47; Crabb 1968 \\
\hline & $\mathrm{x}$ & Antelope Creek 22 & Krieger 1946, 47; Crabb 1968 \\
\hline
\end{tabular}

${ }^{\mathrm{a}} \mathrm{X}$ indicates an unknown frequency of occurrence. 
pipes or cloud blowers (Studer 1934; Harrison 1984). These forms contrast markedly with the more conventional elbow forms which also occur on Antelope Creek phase sites, but more frequently are found throughout the southern Plains Village area. Specific sources for the cloud blower form are uncertain, but they were very common throughout the eastern Pueblo villages at this time (Switzer I969).

Exotic materials tentatively derived from the Southwest include mica scraps, ground coal amulets, and one fibrolite ax. Specific sources of these items are also uncertain.

\section{IMPLICATIONS OF PUEBLO MATERIAL OCCURRENCES}

The most remarkable characteristic of the list of Pueblo trade goods present on Antelope Creek sites is its redundancy with material classes already present in the Antelope Creek assemblage. Redundancy is especially marked in lithics, ceramics, pipes, and presumably foodstuff. Nowhere is this redundancy more evident than at hamlets near the Alibates quarry. More than 4,273 pieces of obsidian were recovered by WPA crews at Alibates Ruin 28 (Units I and II) and Alibates Ruin 28A. Both sites are within a one-kilometer radius of the Alibates agatized dolomite quarries, and the presence of sizeable Alibates biface caches in the rooms, coupled with the staggering quantities of debitage at these sites, clearly indicates that the Antelope Creek peoples were actively engaged in mining, shaping, and probably trading the locally available agate resource (Bandy I 976).

Pueblo pottery has counterparts among the existing Plains pottery types. Although differences do exist in vessel form and decorative elaboration, it is perhaps significant that cordmarked pottery and basketry containers occur as grave offerings. To date, however, no complete or restorable Pueblo pottery has been recovered from burial contexts (Lintz I986a). ${ }^{2}$ Apparently, Pueblo vessels were eye-catching containers, possibly for other trade goods, and were not especially prized or regarded as suitable for burial accompaniment.

Pueblo pipes are another area of presumed redundancy. Ceramic cloud blowers at Coetas Ruin (Studer 1934), tubular pipes at Chimney Rock Ruins, Alibates Ruins 28 (Unit II) and 30 (Baker and Baker I94I), and stone "Pecos" pipes from the McGarraugh Ranch site (Harold Kachel collection) duplicate the ascribed function of elbow pipes commonly found at these and other Antelope Creek sites (Fig- 


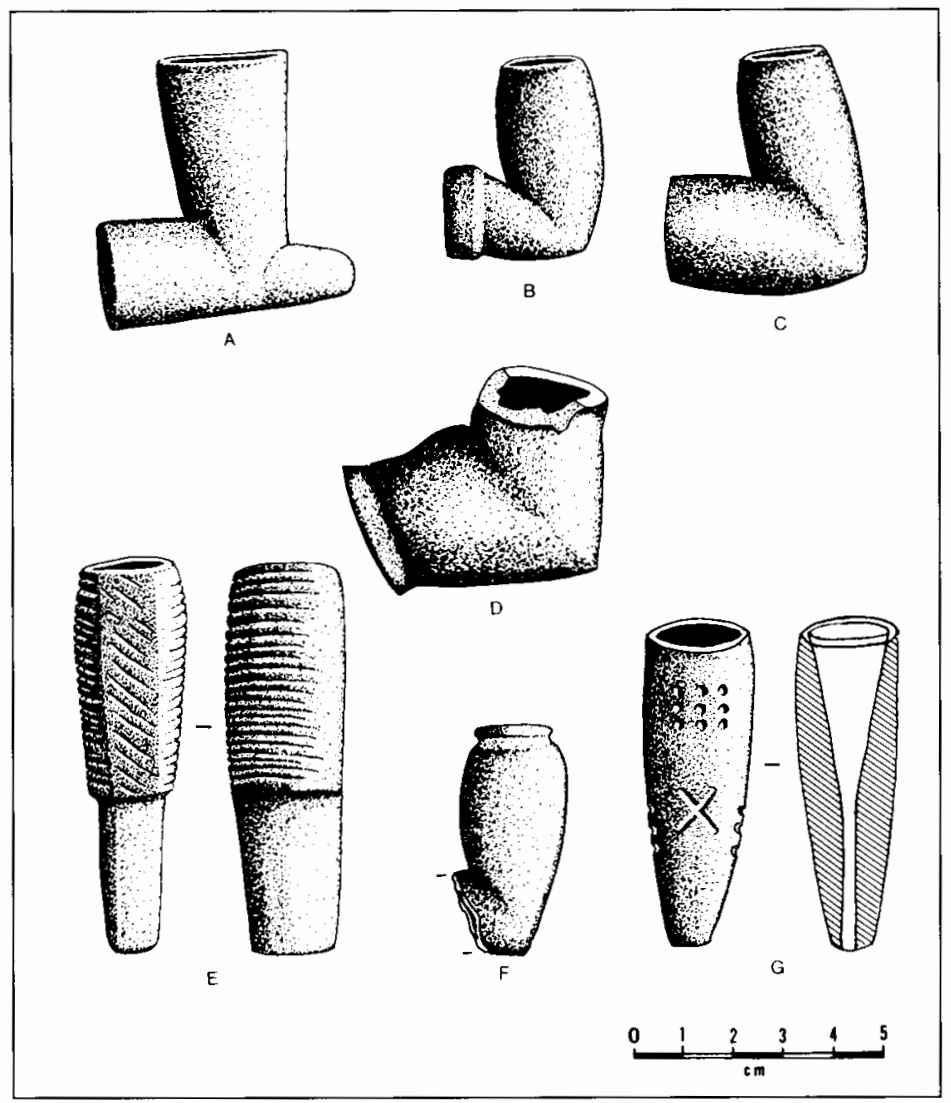

FIGURE 6.2. Select pipes from Antelope Creek sites. A-C: Stamper site, Oklahoma; D: Kiowa Creek, Oklahoma; E-F: Mathews Ranch ruin, Texas; G: Coetas Creek ruin, Texas; Specimens A-F are from the Harold Kachel Collection; specimen $\mathrm{G}$ is after Studer 1934.

ure 6.2). Although most of the pipes from eastern Pueblo villages during Pueblo IV (A.D. I325-I600) are straight tubular and straight conical ceramic forms (Switzer 1969, 32), pipes from Antelope Creek phase sites generally display a wide range of variability in form and raw material. A study of 25 ceramic and red stone pipes selected from a total of 84 pipes reported by WPA archaeologists from Antelope Creek Ruins 22 and 24, Alibates Ruin 28, and Chimney Rock Ruin 5 I recorded 15 stone and ceramic elbow forms, 7 ceramic tubular forms, and 3 unidentifiable ceramic pipes (Harrison 1984). At Alibates Ruin 
28, the WPA archaeologists recovered 42 pipe fragments; five of the 27 examples from Unit II (postdating A.D. I 350) were tubular forms, but all pipes from the earlier Unit I were elbow types (Baker and Baker 1941).

The final area of redundancy presumably involves actual foodstuff. The presence of a chipped-stone tool assemblage geared toward hunting (including abundant projectile points, scrapers, and diamond beveled knives) and a bone assemblage frequently containing bison tibia digging-stick tips, and scapula hoes documents the indigenous procurement of meat and horticultural products. Although few excavators have systematically sought to recover and analyze flotation remains, evidence of bison bone reduction for the extraction of marrow and grease is abundant (Duffield 1970; Lintz 1976; DeMarcay I986). Besides bison, other animals in the faunal assemblages include deer, antelope, prairie dog, cottontail, jackrabbit, ground squirrel, gopher, kangaroo rat, wood rat, bobcat, raccoon, beaver, muskrat, dog, badger, fox, terrapin, aquatic turtle, frog, fish, freshwater mussel, lizard, snake, various gallinaceous birds, and waterfowl (Duffield 1970; DeMarcay 1986). Charred plant remains include corn, beans, squash, grass seeds, Indian mallow, prickly pear, persimmons, hackberry, mesquite, buckwheat, cattail stems, goosefoot, purslane, juniper berries, and "sunflowers" (Keller 1975, 22; Dean 1986, 32-33; Green 1986). A pollen analysis of Landergin Mesa samples found high percentages of pine from metate washes, whereas the wall plaster and cists contained pollen of cheno-ams and cattails (Dean 1986). The reliance on these diverse wild and domesticated plant remains reflects a broad-spectrum exploitation pattern. Present biotic resources in the Texas Panhandle include more than I Io indigenous species with some economic potential (Lintz I986a, Table 9). Although the nature of incoming exchange foods is uncertain, in all likelihood the kinds of goods would have been similar to products already available to groups in the Texas Panhandle.

The intensity of Plains-Pueblo interaction is reflected in changes in the overall frequency of material remains and the range of Pueblo artifacts recovered from Early and Late Subphase Antelope Creek sites. Detailed analysis is hindered by the paucity of absolutely dated sites, the scarcity of assemblage descriptions, and the poor documentation of intrasite provenience of materials. Tentatively, however, Early Subphase sites (A.D. I200-I350) contain ceramics, obsidian, worked coal, and Olivella shell beads. The Late Subphase sites (A.D. 
I 350-I 500) yield these items plus tubular pipes, turquoise, shell tinklers, and shell gorgets.

A more dramatic trend in Pueblo interaction is reflected in the increase in the quantity of products after A.D. 1350. This shift is most clearly apparent at Alibates Ruin 28, where the WPA excavations yielded only io Southwestern sherds, 2 pieces of worked coal, I 3 pieces of obsidian, and Io shell beads from a $16,318 \mathrm{ft}^{2}\left(\mathrm{I}, 5 \mathrm{I} 6 \mathrm{~m}^{2}\right)$ Early Subphase excavation area. In contrast, the adjacent Late Subphase area, which was nearly three times as large $\left(44,240 \mathrm{ft}^{2} ; 4, \mathrm{I}\right.$ Io $\mathrm{m}^{2}$ ), yielded at least 4,132 pieces of obsidian (records are available for only 322 of the 439 ten-by-ten-foot excavated "sections"), I 78 Southwestern sherds, 2 pieces of worked coal, 5 tubular pipes, I 2 turquoise items, and 46 shell artifacts from midden contexts in front of the later structures (Baker 1940a, $5 \mathrm{I}$; Baker 1940b, 44; Baker and Baker I940, 20). When adjusted for the different excavation areas, these differences reflect a 46 -fold increase between the Early Subphase $\left(0.023\right.$ trade items per $\mathrm{m}^{2}$ ) and the Late Subphase (1.064 trade items

per $\mathrm{m}^{2}$ ). These values indicate the marked intensification of PlainsPueblo interaction after A.D. 1350. Similar density patterns occur at other sites, but the locational differences render quantitative variability difficult to interpret.

\section{LATE PREHISTORIC INTERACTION: THE MODEL}

An exchange system in which redundant commodities were traded would be highly valuable in regions subject to periodic shortfalls in resources. Both the Plains and eastern Pueblo areas may have experienced such economic uncertainty during the late prehistoric period. The Pueblo area was undergoing population "packing," which is reflected in the growth of settlements in the Rio Grande valley after the depopulation of the Four Corners area. This growth is manifested in the appearance of Pueblo settlements in marginal areas away from rivers and at higher elevations (Cordell 1980; Anschuetz 1984). It is this packing of people in the northern Pueblo area, starting by about A.D. I 325 (Ellis I98I, 4 I 5 ; Bronitsky 1982; see also Speth, Snow, and Wilcox, this volume), rather than the reorientation of trade relationships between the Southwest and Mesoamerica following the collapse of Casas Grandes (Baugh I984a, 27; Baugh 1986, 182), that led to the beginning of sustained contacts between the Southwest and the Plains. The northern Rio Grande pueblos, which were the source 
of most Southwestern trade goods recovered from Antelope Creek phase sites, were not strongly aligned with the Casas Grandes spheres of interaction (see Wilcox, this volume).

At the same time, populations on the Plains were subject to the localized droughts that characterized the Pacific Climatic Episode (A.D. I250-I 550). These droughts may have ultimately led to a shift in southern Plains adaptations. As Plains-Pueblo trade was intensifying (after A.D. I 350), there is evidence to suggest a decline in horticultural production between the Early and Late subphases. Few reports for dated Antelope Creek phase sites have quantified artifact assemblages, and the abundance of broken metate fragments incorporated as building elements in structures prevents the use of ground stone quantities for assessing changes in the economic patterns. Nevertheless, the densities of bison scapula hoes and tibia digging-stick tips from Early Subphase sites (Pickett, Roper, Alibates Ruin 28 [Unit I] and Arrowhead Peak sites; average 0.036 tools per excavated $\mathrm{m}^{2}$ area) are nearly twice as high as comparable tool densities from Late Subphase sites (Spring Canyon, Black Dog Village, Footprint, and Alibates Ruin 28 [Unit II] sites; average 0.023 tools per $\mathrm{m}^{2}$; Lintz I986a, Table 3I). The same pattern exists when the two bone tool types are independently examined or when the comparison is restricted to similar types of sites.

Direct comparisons of faunal densities (e.g., estimated meat weight per excavated site area) from Early and Late Subphase sites are hampered by faunal recovery problems, and the Antelope Creek practice of systematically reducing bones into small, unidentifiable fragments during the process of extracting marrow and grease (DeMarcay 1986 ). The relative importance of hunting activities, however, may be inferred from the quantities of projectile points at Early and Late Subphase sites. The same sites used in the previous bone tool analysis show no significant change in the density of projectile points between the Early Subphase (average 0.23 points per $\mathrm{m}^{2}$ ) and the Late Subphase (average 0.24 points per $\mathrm{m}^{2}$ ). This relatively constant density of projectile points, coupled with the decrease in the density of presumed horticultural implements between the Early and Late Subphase, may indicate the beginning of a decline in local production of cultigens and an increase in hunting.

The nature of the Plains-Pueblo trade context-be it multigroup rendezvous, formal community alliances, informal exchange between households, gambling, and/or trade partnerships-remains 
uncertain. This context may have been similar to that of the historic Calumet Ceremony, which involved the giving of tobacco, pipes, gifts, and more important, food (Blakeslee 1975). Tobacco was one of the early trade commodities specifically requested by Plains groups from the Spaniards (see Levine, this volume). It was used in ceremonies by the mid seventeenth century and probably served as a medium for reducing intertribal tensions-especially among groups speaking different languages. The expected giving of food during times of plenty helped to ensure the receipt of foodstuffs during periods of scarcity. Ceremonies such as the Calumet were mechanisms that provided a means for keeping societies open and for obtaining access to resources in adjacent areas through the peaceful intergroup exchange of food resources. As such, trade was an effective "redistribution" system useful in buffering against the uncertainty of local hunting, foraging, and horticultural success during periods of intermittent drought. It is precisely this buffering mechanism that underlies and sustains the trade relationships among small-scale horticulturalists conducting redundant subsistence practices during the late prehistoric period.

Marked changes occurred in the structure of Antelope Creek adaptations and interactions after A.D. I350. The abandonment of subhomestead sites (field huts?), the intensification of trade, and the shift toward isolated structures may signal an increased trend toward bison hunting (bison may have congregated in the Canadian River valley during droughts), and less settlement permanency. The occurrence of sites on mesa tops and the dismembered human skeletons and skull pile at the Footprint site suggest that some external raiding behavior may have been employed to control resources within or adjacent to the Texas Panhandle (Moorehead I931; Haynes 1932; Holden 1933; Green 1986; Lintz I990). Alternatively, the aggression may have been used by recent immigrants to evaluate the relative strength or tactical skills of local populations on the southern Plains (see Spielmann, this volume).

The short-term effectiveness of the buffering strategies employed to maintain a Plains Village pattern is uncertain, since details of the microevolutionary changes have not been delineated. Over the long term, the buffering strategies were insufficient to permit continuation of the Plains Village pattern, and the Antelope Creek people either abandoned the trappings of sedentism entirely and adopted radical changes in ceramic and lithic technologies or, more likely, 
moved east or northeast and coalesced with other Plains Village groups. The impact of climatic change and/or continued Athapaskan intrusion during the I 500 s have yet to be delineated.

\section{PROTOHISTORIC INTERACTION}

By the sixteenth century, the alliances and structure of Plains-Pueblo interaction were quite different from those of the late prehistoric period. Present evidence suggests little to no temporal discontinuity in contacts (Baugh 1986; cf. Collins 1971), but major shifts in the adaptive structure and location of groups are evident. The Canadian River valley and the northern Texas Panhandle region contained few substantial villages and may have been controlled by Athapaskan groups (Hughes 1979). Several protohistoric period nomadic and/or semisedentary complexes with radically different ceramic traditions exist south and east of the Canadian River valley. In the Texas Panhandle these include the Tierra Blanca complex (Spielmann I982, 1983; Habicht-Mauche 1987), and to the south the Garza complex (Runkles 1964; Johnson et al. 1977). The Wheeler phase, formerly consisting of the Wheeler and Edwards complexes, occupied western Oklahoma (Baugh I982, I984a, I986; Hofman I984b).

All of these manifestations document a tremendous increase in the apparent quantity of Pueblo and Caddoan trade materials (Hofman 1978; Baugh and Swenson 1980; Spielmann 1982, I983). The trade items resemble the same general kinds of material classes found in the Antelope Creek phase: obsidian, turquoise and shell jewelry, ceramics, and pipes. Ceramics in particular display an incredible range of types (Baugh and Swenson I980). Recent studies, however, have documented that some ceramics may be local southern Plains imitations; thus these assemblages may require petrographic analysis to ascertain the extent and direction of trade (Habicht-Mauche I987 and this volume; Runkles and Dorchester I987, I09). Regardless of ultimate sources, the close ceramic resemblances to Pueblo and Caddoan wares on these Plains sites are indicative of strong contacts with groups to the east and west.

Two opposing models-macroeconomy and mutualism-have been formulated to account for the structure of the protohistoric exchange systems (see Spielmann, this volume). Whatever the nature of the protohistoric interaction, both models maintain that contacts were more intense and involved specialization in the production of 
complementary economic resources. This protohistoric pattern displayed by the Wheeler, Garza, and Tierra Blanca manifestations contrasts markedly with the Antelope Creek phase pattern evident in the late prehistoric record.

By about A.D. I 500, the following shifts are evident:

I. The location of semisedentary settlements on the Plains reflects a marked shift to the south. Whereas the late prehistoric Plains populations resided in the Canadian River valley of the Texas-Oklahoma Panhandle, the culturally distinct protohistoric groups reside along streams in the lower Texas Panhandle. This shift in home range may reflect control of the Canadian River valley by Athapaskans.

2. There is a marked expansion in the interaction networks, with more intense contacts with the Caddoan area, the Great Bend region along the Arkansas River, and the eastern Pueblos in the Southwest.

3. Resident populations on the Llano Estacado display a more nomadic hunter-gatherer lifestyle, as reflected in the scarcity of villages and the simplicity of architectural forms.

4. Undoubtedly there is increased specialization in economic orientation and a shift from redundant to complementary resources. After A.D. 1500 , the resident Plains populations are primarily huntergatherers, with an intense emphasis on bison exploitation.

Other fundamental differences between the late prehistoric Antelope Creek phase and the various protohistoric complexes should emerge as cultural details of these manifestations are reported. These shifts have widespread implications for the culture changes that occurred in both regions.

\section{SUMMARY}

This chapter has focused on the nature of late prehistoric PlainsPueblo exchange from the perspective of one Plains Village group residing in the Texas Panhandle. The structure of the exchange involving the Antelope Creek people reflects a pattern quite different from that modeled for various manifestations of the protohistoric period. What began as an environmental buffering strategy among sedentary groups with similar economies evolved into a system of economic mutualism involving critical complementary resources during the protohistoric period. The origins of the mutualistic exchange are rooted in the economic uncertainties facing the Antelope Creek populations during the Pacific Climatic Episode. The require- 
ments of the economic change necessitated major readjustments in the structure of the Plains societies. Such changes may have had as much of an impact on the protohistoric period groups as the occurrence of subsequent climatic change or the presence of Athapaskans.

\section{ACKNOWLEDGMENTS}

This chapter benefited from suggestions provided by Amy Earls and unpublished information provided by Glenna Dean, Bill Harrison, and Robert J. Mallouf. Dr. Harold Kachel, Panhandle State University, Goodwell, Oklahoma, gave permission to publish sketches of pipes from his collection. Helpful comments on the chapter were provided by Tim Baugh, Bill Harrison, Jack Hofman, John Speth, Katherine Spielmann, David Snow, and David Wilcox.

\section{NOTES}

I. Alibates agate was probably exchanged as flake blanks and perhaps large, shaped bifacial cores and such finished artifacts as beveled knives, snub-nosed end scrapers, drills, and projectile points (Bandy I976).

2. One sherd of Pueblo pottery was found in burial grave fill during the WPA excavations of Antelope Creek Ruin 22, but the project archaeologist attributed the sherd to an incidental inclusion. 


\title{
7. Ecology and Exchange: The Dynamics of Plains-Pueblo Interaction
}

\author{
TIMOTHY G. BAUGH
}

Prior to the Hispanic entry into the New World, protohistoric southern Plains societies participated in a regional exchange system involving Southeastern and Southwestern communities, each with its own set of commodities. The total system has been defined as the Southern Plains Macroeconomy (Baugh I984b). Although the interaction with the Kadohadacho to the east was intensive, this chapter examines only that segment of the exchange system that involved the eastern frontier Pueblo communities of New Mexico (Cordell I989, 3 I9-324). It focuses on the economic subsystems of prehistoric and protohistoric southern Plains and Pueblo peoples (including farming, hunting, and plant-collecting strategies). By examining the changing relationships among these subsystems, the significance of Plains-Pueblo exchange to the adaptations of these populations can readily be discerned.

This study begins with an examination of the Early Plains Village period in the prairie-plains region of Oklahoma. Known as the Washita River phase (A.D. I 200-1450), these southern Plains people centered their economy primarily on the production of corn, beans, and squash. Through a series of social and economic changes, the Washita River phase evolved into the Wheeler phase (A.D. I450-I 700). Beginning with this Middle Plains Village period, southern Plains Indians lived in fortified villages and placed greater emphasis on bison hunting than had their predecessors. Another important difference between the earlier Washita River phase and this phase is the latter's greater emphasis on exchange. To explain better the significance and vitality of this exchange network, the last section of this 
chapter examines the impact of Spanish conquest and settlement in northern New Mexico on native societies and their institutions.

By integrating archaeological, ethnographic, and ethnohistorical approaches, southern Plains and Southwest cultures can be viewed as components of a dynamic and adaptive system. Adaptations made by these Indians are concerned with only a few key species of plants and animals, as well as other human communities. In other words, the dependence on a few important resources that may crosscut environmental boundaries implies that cultural adaptation is best understood as an interactive system, not as an environmental adjustment (see Flannery 1968; Hofman I984a). From this perspective, cultural transformations arise in response to interactive changes within the total system. These transformations may occur because of either endogenous or exogenous factors. Emphasizing one factor over the other, however, understates the vibrant responses of a culture and its participants to these changes. It is the interaction between these factors and the human players that draws our attention. Culture change, then, must be viewed as a reactive process involving a particular response to stress (whether cultural, social, or environmental), and is not simply teleological (i.e., moving directly toward a specified goal|, nor does it arise from any need to improve lifestyles or the quality of life.

\section{EARIY PLAINS VILLAGE ADAPTATIONS ON THE SOUTHERN PLAINS}

The Washita River phase, found in central and western Oklahoma, dates from A.D. I 200 to I 450 (Drass and Swenson I 986; also, see Fig. 7.I). Occupying square to rectangular wattle-and-daub houses, these sedentary Early Plains Village farmers lived in small hamlets scattered along the winding waterways of the southern prairies. The landscape of the western portion of this area consists of a mixedgrass prairie that covers the rolling redbed hills. To the east, their range is a tree-studded prairie known as the Osage Savanna, which supports a more verdant, tall-grass biome. The villages of these Plains Caddoan people are separated from one another by only a few kilometers and are relatively small, consisting of ten or fewer structures. Although these numerous and nucleated settlements are dispersed widely over their territory, the population density seems to have been relatively high when viewed on a regional basis (Bell 1973, 


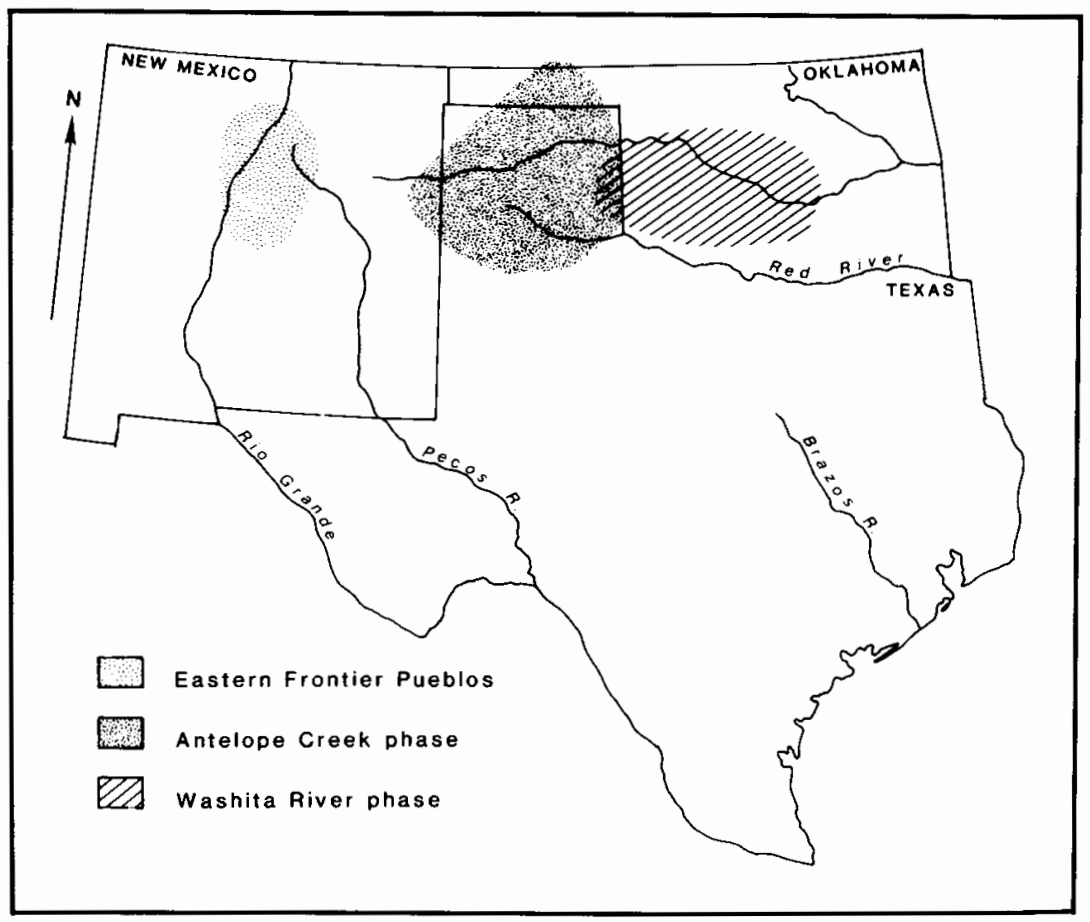

FIGURE 7.I. Distribution of archaeological cultures in the southern Plains and Southwest: Early Plains Caddoan (Antelope Creek and Washita River phases) and the eastern frontier Pueblos (A.D. I 200-1450).

I984). In addition to houses, other features include numerous cache pits, middens, and hearths. From a number of these features there is evidence of corn (in the form of cob fragments, kernels, and cupules), as well as beans (Phaseolus sp.), gourds (Lagenaria sp.), and cucurbits (Cucurbita sp.) (Bohrer I986a, I987b; Brooks I987, I16; also see Table 7.I).

Although corn, beans, and squash form the American triumvirate, other possible cultivated or tended plants include species formerly associated with the Eastern Agricultural Complex (Jones I936; Ford I 98I). Among these cultigens are sunflowers (Helianthus sp.), marsh elder (Iva), knotweed (Polygonum), goosefoot (Chenopodium), and pigweed (Amaranth) (Bohrer 1985; Brooks I 987). Wild plant foods also played an important role in the lives of Washita River phase people. Botanical remains include grapes (Vitis), ground cherry (Physalis), purslane (Portulaca), sand plums (Prunus), and hackberry 
Table 7.1. Floral Remains from Selected Early Plains Village Sites and One Middle Plains Village Site (34WA2) in Oklahoma

\begin{tabular}{lllll}
\hline Species & 34 GV32 & 34 CU27 & 34EL25 & 34WA2
\end{tabular}

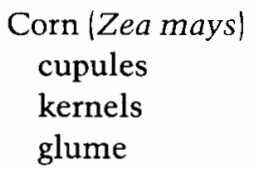

Beans (Phaseolus sp.)

Cucurbitae species

Panic grass (Paniceae)

Maygrass (Phalaris)

Sporobulus/Eragrostis

Chenopodium/Amaranthaceae

Bullrush (Scirpus)

Sandbur (Cenchrus)

Cocklebur (Xanthium)

Sunflower (Helianthus)

Marsh elder (Iva)

Ground cherry (Physalis)

Mustard (Brassica)

Tansy mustard (Drescurainia)

Smartweed (Polygonom)

Portulacaceae/Caryophyllaceae

Morning glory (Ipomoea)

Spurge (Euphorbia)

Passionflower (Passiflora)

Plum (Prunus)

Grape (Vitis)

Ragweed (Ambrosia)

Physalis/Solanum

Crabapple (Pyrus)

Viburnum

Walnut (Juglans)

Oak (Quercus)

Hackberry (Celtis)

\begin{tabular}{|c|c|c|c|}
\hline$t^{a}$ & + & + & + \\
\hline+ & + & + & - \\
\hline- & + & + & -. \\
\hline+ & - & - & - \\
\hline+ & - & - & - \\
\hline- & - & - & + \\
\hline- & - & - & - \\
\hline- & - & - & + \\
\hline+ & - & + & + \\
\hline- & + & - & + \\
\hline- & + & - & - \\
\hline- & - & - & + \\
\hline+ & - & + & + \\
\hline+ & - & - & - \\
\hline+ & + & - & - \\
\hline+ & - & - & - \\
\hline- & + & - & - \\
\hline+ & + & - & + \\
\hline+ & - & - & + \\
\hline+ & - & - & - \\
\hline+ & - & - & - \\
\hline+ & - & - & - \\
\hline+ & + & - & $?$ \\
\hline- & $?$ & - & - \\
\hline- & + & - & - \\
\hline- & + & - & - \\
\hline- & + & - & - \\
\hline- & + & - & - \\
\hline- & $?$ & - & - \\
\hline+ & - & - & - \\
\hline- & + & - & - \\
\hline
\end{tabular}

SOURCE: Brooks 1987, 114-120; Bohrer 1985; Bohrer 1986a.

${ }^{\mathbf{a}}+=$ presence

- $=$ absence 
(Celtis) (Bohrer 1985; Brooks 1987). In more western localities, such as the Heerwald site $\left(34 \mathrm{CU}_{27}\right)$, nuts (especially walnuts [Juglans sp.] and perhaps pecans [Carya sp.]) may have been an important addition to the diet, because they are commonly found in cache pits, hearths, and midden areas (Bohrer 1985).

Hunting medium-to-large game, such as deer and bison, also provided important sources of food for the Washita River phase people. In the more eastern sites of the Osage Savanna (such as Grant [34GV2], Lee [34GV4], and Arthur [34GV32]), deer tend to outnumber bison, in some cases by as much as four to one but in most instances by much smaller ratios, with an average of between $2: 1$ and I:I (see Table 7.2, which is based on the minimum number of individuals; see also Sharrock I961; Richards 1971; Brooks I987). Schmitt (1950, 70-7I) notes for the Lee site $\left(34 \mathrm{GV}_{3}\right)$ that "On the basis of bone refuse, it can be said that the chief animal hunted was the deer, but jack rabbits [sic], tortoises, and wild turkey were also important food items." These sites are located in the tall-grass prairie and may therefore reflect only a seasonal use of bison. Deer were hunted throughout the year, including much of the winter, while bison made up a larger component of the diet during the warmer months, when the tall grasses are at their prime.

As one moves west, however, the dependence on deer decreases dramatically, with a I:I ratio of bison to deer at best, and more commonly a $2: \mathrm{I}$ or even 4 : I ratio (Table 7.2). This increase in bison is not only geographical but temporal as well. For example, the Washita River phase people substantially increased their use of bison in comparison to the preceding Custer phase (A.D. 800-I250) in western Oklahoma (Drass and Flynn I990), which reflects not only' the greater availability of bison but an increasing dependence on horticultural production (see Speth and Scott I 989; Speth, this volume). The western mixed grass prairie has a higher percentage of wintersustaining short grasses, which retain their nutrients and calories. Consequently, this prairie tends to support more bison during the colder months than the less nutritious tall grasses of the eastern prairie during the same season (Wedel 1986, 16). As a result, bison appear to have been available year-round to the westernmost Early Plains Village people living in the mixed grass prairie.

In the western Plains, the availability of bison seems to have offset, at least somewhat, the need for supplemental species. Still, wild turkeys may have been of some significance. In the Osage Savanna, cot- 
Table 7.2. Faunal Remains and Minimum Number of Individuals from Five Selected Early Plains Village (A.D. 1200-1450) Sites in Oklahoma

\begin{tabular}{|c|c|c|c|c|c|}
\hline Species & $34 \mathrm{GV} 2$ & 34GV3 & 34GV32 & 34WA5 & $34 \mathrm{CU} 27$ \\
\hline Bison bison & 11 & 13 & 16 & 4 & 43 \\
\hline \multicolumn{6}{|l|}{ Odocoileus virginianus } \\
\hline (deer) & 23 & 54 & 22 & 6 & 8 \\
\hline \multicolumn{6}{|l|}{ Antilocapra americana } \\
\hline (pronghorn) & 1 & 1 & $-{ }^{a}$ & 2 & - \\
\hline Cervus canadensis (elk) & - & 1 & 1 & - & - \\
\hline Canis sp.? (coyote/dog) & - & - & - & 1 & 3 \\
\hline Taxidea taxus (badger) & 1 & 1 & - & - & 1 \\
\hline \multicolumn{6}{|l|}{ Castor canadensis } \\
\hline (beaver) & 2 & - & - & - & 2 \\
\hline Procyon lotor (raccoon) & 1 & 1 & - & - & - \\
\hline \multicolumn{6}{|l|}{ Lepus californicus } \\
\hline (jack rabbit) & - & - & 2 & 5 & 3 \\
\hline \multicolumn{6}{|l|}{ Sylvilagus floridanus } \\
\hline (eastern cottontail) & 24 & 23 & 12 & 15 & 10 \\
\hline \multicolumn{6}{|l|}{ Mephitis mephitis } \\
\hline (skunk) & - & 2 & - & - & 1 \\
\hline
\end{tabular}

SOURCE: Brooks (1987); Drass et al. (1987); Pillaert (1963); Richards (1971);

Sharrock (1961); Schmitt (1950).

${ }^{a}+=$ presence

- = absence

tontail rabbits appear to have been an important secondary or backup species. The only small species to cross-cut both the eastern and western ranges is the ornate box turtle. This terrapin is collected in the spring as a meat supplement that can be either baked or stewed. The midsummer season, between the periods of planting and harvesting, may also have been an important time for collecting turtles.

In summary, the Washita River phase people tended to rely on locally available resources. Domesticated plants (including corn, beans, and squash) were the mainstays of their economy, but tended crops (such as sunflowers and marsh elder, among others) may have been significant additions to the diet. These vegetable products were supplemented with a variety of wild plant foods, which may have been mixed with bison fat and meat to provide valuable nutrients 
Table 7.2 (Continued)

\begin{tabular}{|c|c|c|c|c|c|}
\hline Species & $34 G V 2$ & $34 \mathrm{GV3}$ & $34 G V 32$ & 34 WA5 & $34 \mathrm{CU} 27$ \\
\hline \multicolumn{6}{|l|}{ Cynomys ludovicianus } \\
\hline (prairie dog) & - & - & 1 & - & 3 \\
\hline \multicolumn{6}{|l|}{ Geomys bursarius } \\
\hline (pocket gopher) & 11 & 8 & 1 & 43 & 14 \\
\hline Neotoma sp.? (wood rat) & 2 & 10 & - & - & 1 \\
\hline Citellus sp.? (squirrel) & - & 1 & 3 & - & - \\
\hline \multicolumn{6}{|l|}{ Spermophilus } \\
\hline \multicolumn{6}{|l|}{ tridecemlineatus } \\
\hline \multicolumn{6}{|l|}{ (13-lined ground } \\
\hline squirrel) & - & - & - & - & - \\
\hline \multicolumn{6}{|l|}{ Didelphis marsupialis } \\
\hline (opossum) & 1 & - & - & - & - \\
\hline Lynx canadensis (lynx) & 1 & - & - & - & - \\
\hline Turtles & 15 & + & 11 & 9 & 39 \\
\hline Fish & + & + & + & + & + \\
\hline Birds & + & + & + & + & + \\
\hline \multicolumn{6}{|l|}{ Meleagris gallopavo } \\
\hline (turkey) & 2 & + & 5 & 1 & 4 \\
\hline \multicolumn{6}{|l|}{ Tympanuchus cupido } \\
\hline (prairie chicken) & 2 & - & 1 & 1 & 1 \\
\hline
\end{tabular}

during the winter months. Bison in the west and deer in the east played an important role in the diets of these people as well.

In a similar manner, lithic materials and other nonsubsistence goods were acquired from local sources. As the acquisition of these local resources suggests, exchange relationships with Pueblo groups appear to have been minimal during this period. Only an occasional black-on-white sherd or exotic stone (such as turquoise or obsidian), as well as other commodities, appear in the Early Plains Village archaeological record. Even then, commodities such as obsidian were acquired as frequently from sources to the north as to the west (Baugh and Nelson 1987, 1988).

During the latter part of the Washita River phase, however, certain botanical indicators point to a shift in the subsistence pattern of 
these Plains people. For example, cache pits that have been dated to post-A.D. I350 contexts contain only small amounts of corn and relatively large quantities of sandbur seeds (Cenchrus sp.). Sandburs have been found at several sites, such as Heerwald $\left(34 \mathrm{CU}_{27}\right)$ and Linville (34RM492), in western Oklahoma (Bohrer 1986b; Drass et al. 1987; Drass and Moore 1987). For the larger Heerwald site, Bohrer $(1985,20)$ states, "circumstantial evidence indicates sandbur utilization was part of an episode of intensive wild plant collection during a period when maize could have been in short supply. The pit deposit has other wild plant remains with a known history of Indian utilization, and has but scant evidence of maize." Furthermore, she notes that "Precedence for the use of burgrass as food in times of scarcity comes from West Africa (Dalziel I948, 522) and from the examination of human feces from Archaic horizons from southwestern Texas (Williams-Dean I978)" (Bohrer I 986b, 6).

Actually, because the southwest Texas Cenchrus specimens were found in only 2 percent of the Archaic coprolites (or comprised only o. I percent of the total volume of the floral macrofossils) recovered from Hinds Cave, Williams-Dean (1978) was at first somewhat skeptical about the nutritional role of these sandburs. She believed that these seeds must have been introduced by ingestion "with the viscera of rodents or birds, or became incorporated into the coprolites after their deposition onto the seed-littered floor of the rockshelter and during burrowing activities of coprophagous insects and larvae" (Williams-Dean I978, 244). While such a conservative interpretation was of merit at the time of her writing, increasing evidence from Plains Village sites in the southern mixed grass prairie region indicates that while Cenchrus certainly was not a key resource, it may well have served as a secondary source for nutrition and may have been used as a starvation food during periods of poor crop production.

This information, in conjunction with the paleoenvironmental reconstructions of S. Hall (1982, I 984; Hall and Lintz I 984) and others, suggests environmental degradation on the southern Plains. This environmental stress is characterized by decreasing and less predictable rainfall, which would have made growing corn and other crops more difficult and less reliable. For example, among the Antelope Creek phase people in the Texas Panhandle there is evidence that their once abundant harvests were adversely impacted around A.D. I 350 (Levendosky I987, IOO-IOI). The contiguous-room structures of these Early Plains Village people, found along the margins of the 
Canadian River, were being abandoned for smaller settlements that contained single-room dwellings. These later individual structures tend to be located at the heads of small tributaries to the Canadian River, where freshwater springs provide the most reliable sources of water (Lintz r 986a and this volume). Another important strategy may have been the expansion of Antelope Creek and Pueblo interaction (Habicht-Mauche et al. I988). But even these combined adaptive strategies failed with continuing desiccation, and by A.D. I 450 the Antelope Creek people had abandoned their former lifestyle and had either $(\mathrm{I})$ become increasingly reliant on hunting and gathering, (2) migrated farther east and integrated with other groups, or $(3 \mid$ removed themselves from the southern Plains entirely.

Subsistence strategies employed by the Washita River phase people also underwent major shifts at about this same time. For example, bison became even more important in the economies of the Indians in both western and central Oklahoma, and the reliance on deer decreased dramatically. In addition, there was a major increase in the number of trade goods, especially from other Caddoan groups in northeast Texas and from peoples of the eastern frontier pueblos (Baugh I 982, I986). As a result of this shift in economic patterns, a new archaeological culture is recognized-the Wheeler phase, dating from A.D. I 450 to I 700 (Baugh I986; Habicht Mauche I988, I 29-I 40).

\section{MIDDLE PLAINS VILLAGE ECONOMY AND SOCIETY}

There is no doubt that buffalo played an important role in the diet of southern Plains people during the protohistoric period, A.D. I 450 to I 700 (Fig. 7.2; Table 7.3). One hunting strategy utilized by farming people is the organization of communal hunts (Speth and Scott I989). Such an endeavor may well have preadapted these southern Plains farmers to a more semisedentary form of existence.

As Speth (this volume) points out, horticulturalists may reach a critical juncture in midsummer, when their next season's harvest has not come to fruition and their winter supplies have been depleted. This is a period when calories and/or protein could play a vital role in their economy. Concurrently, men and women could not afford to be absent from their home villages for long periods during this season due to the requirements of their horticultural way of life. Furthermore, even though bison aggregate into larger herds for the rutting season, which occurs in this season, this is a most danger- 
ous time to hunt them because of the agitated state of the males. A more opportune period occurs in the late winter and early spring, when the bulls are less aggressive and those cows that are neither carrying nor caring for their young are in good condition.

That bison would have been available in the southern Plains during the spring is attested to by the chroniclers of Don Francisco Vásquez de Coronado's expedition into this region in the mid sixteenth century (Winship I 896). These accounts present evidence that the members of this entrada encountered both Querecho and Teya bison hunters during the spring of $154 \mathrm{I}$. Such accounts are not surprising, because late spring is an excellent time for Plains farmers and the

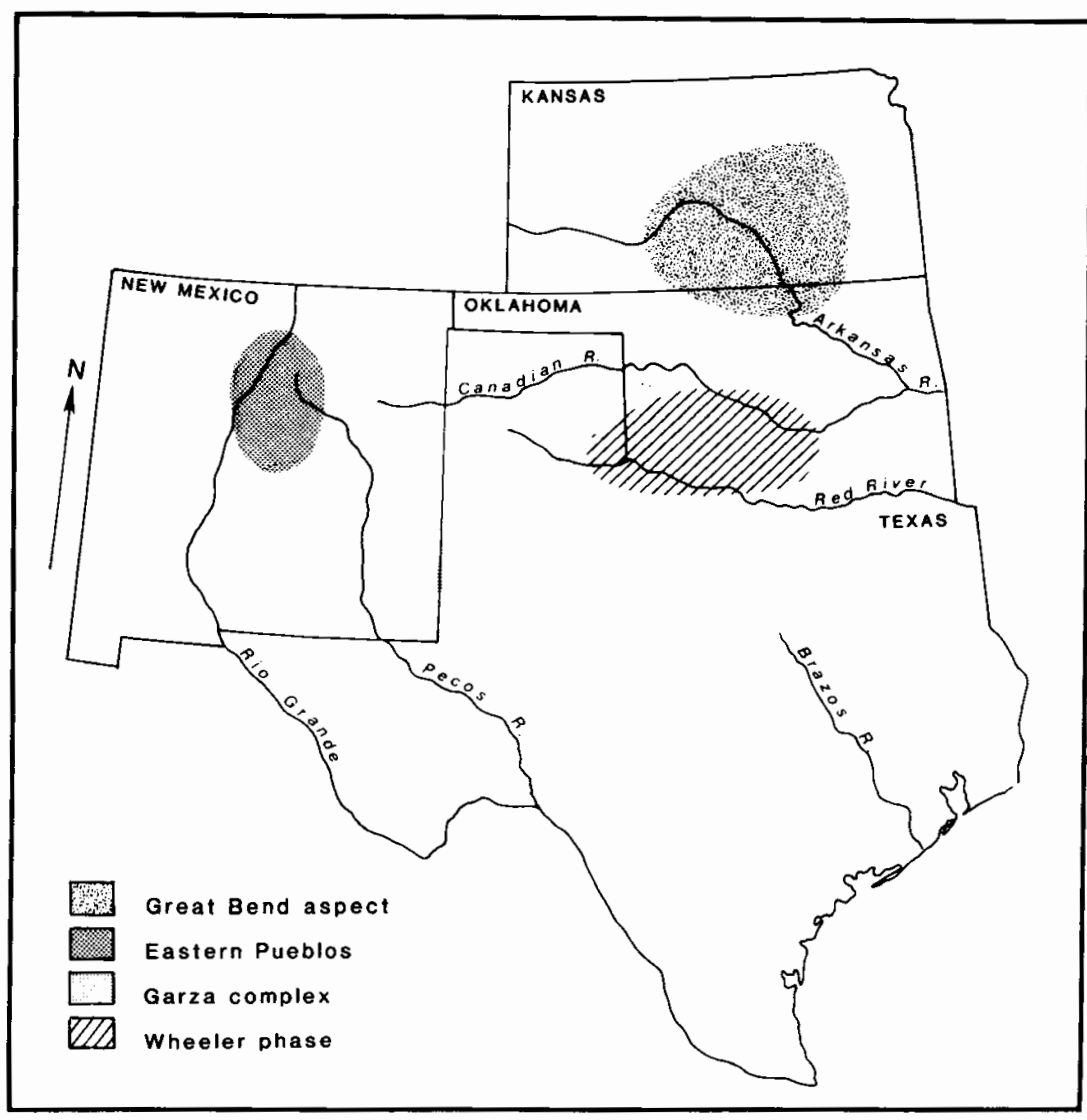

FIGURE 7.2. Protohistoric Plains Caddoan cultures and eastern frontier Pueblos. 
Table 7.3. Faunal Remains and Minimum Number of Individuals from Four Selected Middle Plains Village (A.D. 1250-1470) Sites in Oklahoma

\begin{tabular}{lrrrr}
\hline Species & 34BK2 & 34 WA2 & $34 \mathrm{RM} 14$ & 34GR8 \\
\hline Bison bison & 23 & 16 & 6 & $+^{\mathrm{a}}$ \\
Odocoileus virginianus (deer) & 5 & 2 & 2 & - \\
$\begin{array}{l}\text { Antilocapra americana } \\
\quad \text { (pronghorn) }\end{array}$ & 3 & 2 & 1 & - \\
Cervus canadensis (elk) & - & - & 1 & - \\
Canis sp.? (coyote/dog) & 5 & 1 & 1 & - \\
Lepus californicus (jack rabbit) & 1 & - & 2 & - \\
Sylvilagus floridanus & & & & \\
$\quad$ (eastern cottontail) & 1 & 1 & 5 & - \\
Mephitis mephitis (skunk) & 1 & - & - & - \\
Cynomys ludovicianus & & & & - \\
$\quad$ (prairie dog) & 2 & - & 3 & - \\
Geomys bursarius (pocket gopher) & 3 & 1 & 2 & - \\
Citellus sp.? (squirrel) & - & - & - & - \\
Spermophilus tridecemlineatus & & & & - \\
$\quad$ (13-lined ground squirrel) & 1 & - & - & - \\
Turtles & 205 & 41 & 4 & - \\
Fish & - & 1 & 1 & - \\
Birds & + & + & + & - \\
Meleagris gallopavo (turkey) & - & - & 1 & - \\
\hline
\end{tabular}

SOURCE: Monk, Susan M. 1982. Utilization of Faunal Resources and Exploitation of Environmental Zones in the Southern Plains: The Edwards I Site. M.A. thesis, Dept. of Anthropology, Univ. of Nebraska, Lincoln; and unpublished data from Peggy Flynn and Richard Drass, Oklahoma Archaeological Survey, Norman.

$\mathbf{a}_{+}=$presence

- absence

more nomadic foragers to acquire protein in quantity. The practice of spring bison hunts by Plains Caddoans is underscored by the observations of Colonel Randolph Marcy, who, while leading a campaign to the headwaters of the Red River in late May I 852, encountered "a hunting party of Wichetaws, about 150 in number, and were commanded by an old chief, 'Canaje-Hexie.' They had with them a large number of horses and mules, heavily laden with jerked buffalo meat, and ten wild horses which they had lassoed upon the prairie" (Marcy 1866, I 28). 
In the month of May, or perhaps June, the southern Plains herds frequently came together and "in great measure, abandoned the plains of Texas in summer for those further north, revisiting them [the southern Plains] again in winter" (Allen I 877, 465; cf. Wallace and Hoebel 1952, 54-55). This statement is supported by the observations of Colonel Richard I. Dodge, who in May I87 I found a tremendous herd of bison moving northward to its summer range:

The whole country appeared [as] one mass of buffalo ... and it was only when actually among them that it could be ascertained that the apparently solid mass was an agglomeration of countless small herds of from fifty to two hundred animals, separated from the surrounding herds by greater or less space, but still separated.

As the great herd proceeds northward, it is constantly depleted, numbers wandering off to the right and left, until finally it is scattered in small herds far and wide over the vast feeding grounds, where they pass the summer.

When the food in one locality fails, they go to another, and towards fall, when the grass of the high prairie becomes parched up by heat and drought, they gradually work their way back to the south. (Dodge I959, 283-285)

The summer range of bison also included the high valleys adjacent to the Sangre de Cristo Mountains in New Mexico, where they could be easily hunted by Indians from the more northern pueblos. Such information has been recorded by Bailey $($ I 971,15$\}$, who conducted fieldwork in New Mexico with Indians from Taos Pueblo during the early part of the twentieth century:

The writer's guide and camp man, Sun Elk, who was then 36 years old, said that he was not old enough to go with parties for buffalo, but that his father, who was a great buffalo hunter, killed his first buffalo in Ponil Park [northeast of Elizabethtown], and killed others in the upper valleys of the Vermejo, and that the animals were occasionally killed in Moreno Valley, where he had himself seen their bones and horns.

While bison remains increase from southern Plains protohistoric sites, domestic plant remains decrease in overall number from Wheeler phase sites and the closely affiliated Garza complex sites (Baugh I986; Habicht-Mauche I 987). The meager available evidence indicates that corn, beans, and squash continued to be grown (Bohrer I987a).

In part, the lean evidence for food production at Wheeler phase sites may be due to the introduction of new drying and storage techniques. The ethnographic literature hints that at least some of the 
historic Wichita of the southern Plains no longer used storage or cache pits within their village boundaries. Instead, there were arborlike structures with raised floors located near each of the houses within a village (Curtis I930, 38; Newcomb I96I, 256; Newcomb $1976,6)$. From the rafters of these structures were hung strips of cucurbits, which were later woven into mats and stored. Corn was spread out across the floor and allowed to dry before the kernels were placed in hide bags for storage. Furthermore, Newcomb (1967; Newcomb n.d., I4) argues that once these vegetable products were dried and placed in hide bags, they were stored in underground cache pits similar to those utilized by the Pawnee (Weltfish 1965, 268269).

The archaeological evidence, however, presents conflicting information about the location of these pits. Several Oklahoma sites on the Arkansas and Red rivers show evidence of cache pits within villages (Bell I 984, 369), but evidence from protohistoric Great Bend Aspect sites in Kansas provides somewhat more ambiguous information on this point. A number of the Great Bend Aspect (A.D. I 400I700) sites have been excavated (Lees I990), and although evidence for pit structures and grass-covered houses has been unearthed, these sites contain very few storage pits. For example, in Marion County, nearly $3,000 \mathrm{~m}^{2}$ of surface area were cleared at the Kruse site (14MN504). Realizing that this represents only a small portion of the site (about I I percent), it is still noteworthy that archaeologists uncovered only five cache pits and a shallow depression (Rohn and Emerson I 984, 55-70). At a second site, I4MN509, which is located in the floodplain, more than $348 \mathrm{~m}^{2}$ (out of 27,000 for the entire site) were excavated, with Io storage pits, 2 shallow pits, and 3 post molds being uncovered (Rohn and Emerson 1984, 7I-86). Only one cache pit was excavated at $1_{4} \mathrm{MN}_{527}$ (Rohn and Emerson 1984,70 ), and only a few cache pits were located at $\mathrm{I}_{4} \mathrm{MN}_{32} 8$, some in association with structures (Rohn and Emerson 1984, 89-96; Lees I987, 1989).

Archaeological tests have also been conducted at Great Bend Aspect sites in Rice County (e.g., Malone [ ${ }_{14} R_{5}$ ], and Thompson [ $\left.{ }_{4} \mathrm{RC}_{9}\right]$ ), in Cowley County (including Larcom-Haggard [ $\mathrm{I}_{4} \mathrm{COI}$ ], Elliott [ $\left.\mathrm{I}_{4} \mathrm{CO}_{2}\right]$, and Country Club [ $\left.\mathrm{I}_{4} \mathrm{CO}_{3}\right]$, and in Pawnee County (such as Larned [ ${ }_{4} \mathrm{PA}_{3}$ O7 ]). At none of these sites have archaeologists been able to determine the relationship between structures and storage pits based on their excavation units (Wedel 1959; Monger 1970; Witty 1977; Rowlison I981). 
On the basis of the above information, we might conclude that at least some of the Plains Caddoan peoples may well have attempted to hide their cache pits outside of their village boundaries. Such a practice would provide for safekeeping during their long periods of absence while on their annual bison hunts. If such storage areas were placed away from the main village, archaeologists would not record large numbers of caches during their excavations, and as a result, the degree of reliance on cultigens by the Wichita would be very difficult to ascertain.

Returning to the economic strategies utilized by the people of the Wheeler phase and the Garza complex, two major options were available to these Plains Caddoans that would allow them to deal with drought conditions and the resulting stress on crop production discussed above. These were ( $\mathrm{I}$ ) an intensification of hunting strategies, and $(2)$ an expansion of trade within and beyond the mixed grass prairie region of the southern Plains. The large number of bison bones recovered from these sites in comparison to earlier Washita River phase sites attests to the significance of the first option. Evidence for the trade option is also based on recovered artifacts from Wheeler phase sites, including artifacts made of obsidian, glaze ceramics, and turquoise pendants (see Baugh 1982, 1986; Baugh and Nelson I987). From an internal perspective, each of the Wheeler phase villages seems to have been specializing in the control of specific lithic resources that may have been useful for intraregional as well as interregional exchange (Baugh 1986). On the basis of this evidence, we can conclude that there was a realignment in and intensification of interaction between Plains and Southwestern populations. Indeed, we find that societies to the west along the northern Rio Grande and in the Galisteo Basin were also undergoing changes (Wilcox, this volume). Although this restructuring may have been affected to some degree by the movement of Athapaskan groups into the Southwest during the late fifteenth to early sixteenth century (D. Gunnerson 1956 ; Wilcox $198 \mathrm{rb}$ ), other variables (such as the intensification of farming practices, the availability of certain resources, shifts in alliance structures, and ecological changes) must also be taken into account. For example, the presence of such horticultural features as cobble-bordered, pebble-mulched fields in conjunction with silting or growing pits and field houses in the Galisteo Basin indicates that an increasing amount of time and labor were being invested by the Pueblo horticulturalists in farming. This would 
have decreased the time available to these people to engage in hunting while conversely creating a protein deficiency (see Speth and Scott I989; Speth, this volume).

Although increasingly arid conditions made farming more precarious in the western margins of the Plains Village occupation zone, especially where members of the Garza complex resided, bison hunting conditions seem to have improved (Baugh I 986; Habicht-Mauche I987). Such drought conditions would have caused the shortgrass biome to expand eastward at the expense of the tall grasses. Bison herds, being dependent on these short grasses, would follow and thereby increase their accessibility to Wheeler phase populations.

Concurrently, decreasing precipitation in former shortgrass areas, such as the southwestern portion of the southern Plains, may have stressed the local short grasses to the point that forage for bison was severely limited. As a result, the herds in this area, as well as the individual bison, may have become smaller. This would have made fewer and smaller bison available to Pueblo hunters in this region, possibly causing them to seek this resource through trade.

The Plains-Pueblo interactive system changed during the protohistoric period not only due to the changes in economic practices and environmental variation but also because of shifting political alliances due to the arrival of Athapaskan populations in the southern Plains. Their migration from areas farther north may have been trig. gered by the expansion of tall grasses in the central Plains. Following Wilcox (I98Ib, 226), such conditions would have allowed the more northern Athapaskans to expand into the central grassland region and eventually migrate into the southern Plains along the eastern frontier Pueblo margin. Once in this area, these hunter-gatherers formed new alliances with the Pueblo horticulturalists to the west, which in turn brought about a transformation in the overall PlainsPueblo alliance system. Plains Caddoans found themselves in competition with the Athapaskans, leading to conflict between the two (Wilcox $198 \mathrm{I} b, 227$ ). Coinciding with this development, Pueblo relations became strained with the semisedentary Plains Caddoan farmers/bison-hunters, who had previously been the primary, if not sole, suppliers of Plains commodities to the Pueblos. This competition between Plains groups may have been the major reason the Caddoans (identified as Teya) attacked Pecos and other eastern frontier villages in the Galisteo Basin in the early I 500 (Hammond and Rey I $940,257-258$ ). 


\section{CHANGING HISTORIC PATTERNS OF PUEBLO EXCHANGE}

This new tripartite (Pueblo, Apache, and Plains Caddoan) exchange system-labeled the Southern Plains Macroeconomy (Baugh 1984b) - did not remain stable for long. Transformations in this system occurred as a result of changing economic and social boundaries brought about by ecological processes, both social and physical. In particular, the Spanish intrusion into New Mexico and changing interethnic relations on the Plains must be considered among such processes. The Spaniards affected not only inter-Pueblo exchange relations but also had a profound impact on Plains-Pueblo interaction by controlling the distribution of Pueblo goods and by participating in the exchange system themselves (Spielmann r989a). In addition, the arrival of the Comanche on the southern Plains brought a new participant into Plains-Pueblo interaction and exacerbated hostilities among Plains groups and Hispanic communities.

From their earliest encounters with the Pueblos, Hispanic settlers of the late sixteenth century viewed the Indians as a people lacking political, social, and religious institutions. Spanish officials began to impose their own political structure on the Pueblo villagers in hopes of controlling the native economy, including exchange. This structure included a Pueblo governor, lieutenant governor, sheriff $\mid a l$ guacil), and probably councilmen (regidores), who were responsible for maintaining law and order, presenting the mandates of Spanish administrators, and punishing offenders (Spicer 1962, 390-39 I). Not to be outdone in their quest for control, "The missionaries also appointed caretakers for the church called fiscales" (Spicer 1962, 39I). Thus the eastern frontier Pueblos found themselves subject to strict prohibitions concerning their rituals, including the use of various sacred objects. Franciscan missionaries coupled such a policy with an active program geared to eliminating native languages, or at the very least to making Spanish a lingua franca.

These programs and policies of the Spaniards resulted in more than religious conversion and culture change, for they insured the incorporation of the Pueblo villages into the Hispanic world empire (T. Hall i 988). To understand their impact, these policies must be viewed in terms of their more secular, economic ramifications. For example, Franciscan attempts to eradicate Pueblo rituals included the acquisition and destruction of ritual items-striking at the very heart of the Pueblo economy and exchange. The role of ritual items 
in the historic period has been outlined by Ford (1972a, 1983), who writes that "dependency upon other tribes for ritual paraphernalia was universal in the Southwest, and at the same time it helped to maintain contacts for obtaining other essential items" (Ford I983, 7II). These "other essential items" included the more mundane commodities of trade, such as food, blankets, hides, and tallow.

The Franciscan refusal to learn the native dialects, coupled with the missionaries' attempts to eliminate native languages and replace them with Spanish, may be viewed in this same light. Although they were not successful in their primary objectives, the use of Spanish by the Pueblo "undoubtedly also intensified the isolation and separation of the native dialects" that "probably became unintelligible from one another" during the seventeenth century (Dozier I96I, I4 I; cf. Spicer I962, 327).

Such mechanisms, then, allowed Hispanic officials to segregate and control the northern Rio Grande Pueblo villages, which were already factionalized due to inter-Pueblo disputes and rivalries. For example, the Spaniards used the competition between Taos, Picurís, Pecos, and other pueblos for the Plains trade to separate and isolate the different peoples. Control over Pueblo villages also permitted the extraction of tribute from the villagers within ten years of Spanish settlement, a policy that had been waived in other regions of the Southwest because of the native populations' inability to produce such surpluses (Spicer I 962, 292-293).

One key component in the economy of New Mexico was the PlainsPueblo trade fair. A variety of commodities was exchanged at these fairs. In addition to buffalo hides, the Spaniards placed a high premium on slaves, or piezas, who were used in the silver mines of northern Mexico or as domestic servants in local New Mexican households. Later many of the captives and/or their descendants became genizaros, who were settled in a number of buffer communities between the nomadic Plains groups and the Hispanic and Pueblo communities. Slaves were at first obtained by the Plains Apache through raids on the Plains Caddoans, but the Athapaskans' inability to acquire large numbers of captives and the Spaniards' increasing demands soon led to raids against and enslavement of the Apache themselves (Forbes 1960, I48).

After the reconquest (A.D. I693-1696), relations among Plains and Pueblo populations continued to change. In 1705 the Comanche made their first appearance at the Taos trade fair and were accepted 
as trading partners (Kenner I969, 28). Because many of the Apache local groups had taken up farming and lived in small hamlets, or rancherias, they were easy prey for Comanche raiders. The Jicarilla Apache were soon forced westward into the mountains (Schroeder 1972, 6I). Some even settled at Pecos. By this time, the Pueblos were highly factionalized over the type of alliances being forged with the Spaniards. This factor, coupled with numerous epidemics, made the people of Pecos vulnerable to Comanche depredations, and these Pueblos soon lost their trade advantage.

For various reasons, in the eighteenth century Hispanic officials also attempted to control commerce by regulating trade fairs. As part of this regulatory system, Spanish settlers and Pueblo Indians alike were forbidden by law to engage in independent trade by visiting villages of the nomadic people (Kenner 1969, 36). Furthermore, in order to be sanctioned, trade fair participants had to pay a fee to Hispanic administrators. "The trouble was that hardly anyone could agree on the line between beneficial regulation of trade and monopolistic exploitation by the governor and his alcaldes mayores" (Kessell I979, 366). Still, the fairs were profitable for all concerned:

The New Mexican traders were able to offer an increasing list of European goods. In return for their buffalo hides, meat, tallow, and captives, now the Comanches could obtain cornmeal, bread, and foodstuffs, and also could choose from an array of beads, trinkets, and a wide variety of ironware ranging from knives and axes to bridle bits and cooking utensils. (Kenner 1969, 37)

During the 1750 os, Spanish officials attempted to make peace with the Comanche, but this was soon overturned through the greed of a new administration. By 1786 , peace had been restored between the Spaniards and the Comanche. As part of this peace agreement, the Comanche were to be friendly toward all the Indian allies of New Spain. In exchange, the Comanche received the right to trade at the Taos fair and establish "fairs and free trade with Pecos" (Thomas 1932, 301). For the next three decades, the Spaniards prospered from the Plains trade, which they essentially controlled through political alliances.

\section{SUMMARY AND CONCLUSIONS}

The intensive hunting of bison on the Plains may well have delayed the initiation of food production on the southern prairies, but once 
horticultural strategies were adopted in this region, they strongly influenced the cultural adaptations of these people. During the Early Plains Village period, corn, beans, and squash grew abundantly in the fields of the Washita River phase settlements. Hunting focused on available game, with deer and bison being equally important in the east and bison being utilized predominantly in the west. Trade was limited, with a greater emphasis placed on inter-Caddoan exchange rather than Pueblo exchange. By A.D. I 350, however, the beginnings of change in this system can be detected.

The appearance of starvation foods, especially sandbur seeds, indicates that the bountiful harvests of corn may have been becoming less predictable. This meant that new economic strategies had to be undertaken. Bison began to play an even greater role in the mixed economy of the succeeding Wheeler phase, and trade was reoriented to encompass the eastern frontier pueblos. Before permanent relationships could be solidified with the inhabitants of the Galisteo Basin and the Pecos valley, groups of Athapaskan speakers made their appearance on the southern Plains and in areas surrounding Pueblo villages.

These small bands--or more precisely, local groups of Apache hunter-gatherers-quickly made alliances with their more powerful farming neighbors. Offering bison products in exchange for various crops, obsidian, and turquoise, the Athapaskan groups soon replaced the less reliable Plains Caddoans in overall importance in the economy of the eastern Pueblos. Still, the Plains Villagers may have supplied the Pueblos with certain desirable and rare commodities (such as bois d'arc) in conjunction with supplemental bison products, keeping the Caddoans involved in this exchange system.

The ties between Athapaskan and Pueblo peoples, however, continued to grow stronger. Through the establishment of trade partnerships and intermarriage, the Apache local groups became more familiar with the ways of their farming allies. As a result, many local groups attempted to supplement their own needs with the adoption of food production and ceramic technology while continuing their quest for bison products. The basis of the Apache economic unit continued to be the local group, which established small farmsteads, or rancherias. Once the seeds were planted, weeding and other activities occupied the time and labor of these people. After their crops were harvested, several local groups came together to participate in a communal bison hunt. The mixed economy practiced by these 
Apache was an adaptive strategy aimed at maximizing the acquisition of both plant and animal resources. This dynamic system took another turn with the settlement of the northern Rio Grande area by Spanish colonists.

In attempting to control the native economy of this region, pressure was put on the Pueblo-Athapaskan alliance system by the Spaniards, who were unable to distinguish between friendly and hostile Apache local groups. The small farmsteads of the Apache were easily located by their enemies, and the small number of individuals within a local group were easy prey for these hostile forces. The Apache then were forced into more marginal intermontane zones, where they came under continuing attack by the Comanche. These newest of immigrants later allied themselves with the Plains Caddoans, and both groups aided the Spaniards in their campaigns against the Apache. Indeed, the Hispanic settlers in New Mexico seized every opportunity to befriend these new equestrian hunters and their Plains Village allies (see Levine, this volume).

More important, Comanche adjustments to the southern PlainsPueblo interactive communities were remarkably similar to the early Apache adaptations to this system. There were quantitative differences in band size, to be sure, but there were many qualitative parallels between Athapaskan and Comanche social and political structure. For example, the Comanche, like the Apache, lacked a number of "classic Plains traits," including participation in an interband world renewal ceremony, such as the Sun Dance; the development of limited voluntary associations or sodalities, such as warrior societies; and other tribal integrative mechanisms (see Oliver I962). The Comanche, then, were not organized at a tribal level. Such convergent forms of band-level social organization may be explained best as a pastoral adaptation to the Southern Plains Macroeconomy (in which the Plains Caddoans and eastern frontier Pueblos were key players), as well as to the physical environment of this grassland region. From this perspective, the intertwined variables of ecology, social interaction, and history provide the basis for an anthropological understanding of evolution as process, reactive social change, and human adaptation. Only by employing the diverse forms of information provided by archaeology, ethnology, and ethnohistory can these complex processes be examined and understood. 


\section{ACKNOWLEDGMENTS}

I wish to recognize the courtesy and time provided by many individuals during the writing of this chapter. Those who have made comments on previous versions of the manuscript include Richard R. Drass, Judith Habicht-Mauche, William B. Lees, John Speth, Katherine Spielmann, and Al B. Wesolowsky. Mary Goodman drafted the figures. Of course, any errors contained in this chapter belong solely to the author. 


\title{
8. Changing Contexts of Pueblo Adaptations, A.D. 1250-1600
}

\author{
DAVID R. WILCOX
}

The debate among archaeologists about the nature of Pueblo political organization during the late prehistoric period has become rather polarized in recent years (Cordell 1979b; Cordell and Plog 1979; Plog 1979; Hunter-Anderson 1981; Upham 1982; Graves and Reid 1983; Plog and Upham 1983; Whittlesey I983; Plog 1985; Upham and Plog 1986; Graves I987; Lightfoot I987). Unfortunately, third parties to this dispute are hindered by the fact that neither side has yet adequately published the data that ostensibly form the basis of their positions. While it is therefore difficult to evaluate the substance of the various arguments, the debate has helped to identify several issues of general anthropological interest:

I. The identification of ethnic group residues in the archaeological record. Much effort in the I 930 s and later was devoted to correlating ceramic distributions with linguistic groups in New Mexico and in postulating migrations (e.g., Mera 1934, I935, 1940, 1943; Wendorf and Reed 195 5; Ford et al. I972). Plog (1979) and Cordell (r979b) have attacked weaknesses in the methodology of these arguments but have overlooked the potential for rethinking the data assembled by earlier authors along systemic lines. In particular, the boundaries of ceramic distributions such as Biscuit ware, Jemez Black-on-white, and the glaze temper types (Mera 1935; Shepard 1942) are identifiable archaeologically, and they presumably indicate the boundaries of interaction systems of various kinds, some of which do appear to correlate nicely with ethnic groups reported by the Spaniards (Schroeder I 979|. Further, such boundaries can be traced as they change through time and can be contrasted with other distributions. Some of the relational sets that can thus be defined are settlement systems whose 
organizations and histories can be studied archaeologically. In many cases, I believe that these settlement systems will prove to be the manifestation of ethnic groups whose identity as distinct polities first emerged along the Rio Grande and on the Colorado Plateau in about A.D. I 300 (see Ford et al. 1972).

2. The internal organization of the Pueblo polities. The belief that the Pueblos are today and always were egalitarian in their political organization has long dominated anthropological discussion (see, e.g., Spicer 1962; Dozier 1970; Ford I972b; Riley 1982). An image of the Pueblos has thus been created that may be of some importance in understanding their efforts to survive as distinct ethnic groups in an American society that places such a high value on equality. Yet both ethnographers and archaeologists have found reason to question this image (see Wilcox I98 I a for discussion). Thus the anthropological debate is joined, with both sides seeking to understand Pueblo culture better. Michael Graves has stated the common problem well:

Unfortunately, we are still some way from specifying the relative numeric values associated with prehistoric change in the Southwest and, as a result, conflicting hypotheses can find some level of empirical support. As most archaeologists will recognize, verification problems of the sort described here adhere to all forms of hypothesis testing. Special obligations are thus placed on archaeologists to examine and, if necessary, report the strength and quality of their evidence. (Graves 1987, 247)

3. Stability and change. Incorporation into the Spanish empire and later the American nation resulted in great changes in Pueblo demography, settlement size and location, and economy. In the century between 1598 and 1700 , for example, many settlement systems of 6 to 12 villages were reduced to a single autonomous pueblo. Whether these demographic changes are correlated with changes in religious and social organization, and how large in scale they were, are unresolved questions (Wilcox $198 \mathrm{I}$ a). Recent discussion has centered on how large the Pueblo populations were prior to Juan de Oñate's colonization. Speculation about the potential devastation of disease vectors prior to 1598 has produced urban-scale estimates (Upham 1982, 1984, 1986, 1987), but strong ecological and historical grounds for doubting that epidemics ever occurred (Schroeder 1972; Reff I987a, I987b/ make Upham's claims highly controversial. Another approach has been to use settlement data to estimate population. Kintigh (1985), for example, has shown that there probably were not more than 5,000 people in the seven Zuni pueblos in the late 
sixteenth century; this is a quarter of Upham's $(1982,37)$ estimate.

4. Regional and macroregional systems in which the Pueblo polities were embedded. From the time of Anna Shepard's (1942) pioneering petrographic work, it has been certain that individual pueblos were not wholly autonomous economically. Advances in anthropological theory in the areas of network analysis (Hirth 1978; Hage and Harary 1983), regional analysis (C. Smith 1976; Johnson I977), and world systems theory (Wallerstein I974) have opened up new horizons for the archaeological investigation of Southwestern political economy. Several scales of analysis are involved: interactions among sets of "local" settlement systems that created regional systems; interactions among regional systems that created "macroeconomies" (Baugh 1982, 1984b); and interactions above the scale of macroeconomies that created world systems such as the Mesoamerican world system (Blanton and Feinman I984).

While the fact of Mesoamerican-Southwest connections is undeniable, the nature of the systemic interaction in the prehistoric period is highly controversial (Di Peso 1974; Kelley and Kelley 1975; Mathien and McGuire I986). In contrast, the nature of Plains-Pueblo interaction is much better defined. Analyses of it using both the ecological approach of Speth (1983; Speth and Spielmann 1983; Speth and Scott 1985a, 1985b) and Spielmann (1982) and the macroeconomic perspective of Baugh (I982, I984b, I986; see also Snow I98 I and Wilcox 1984) have been fruitful. Differences of interpretation among these scholars hinge on very different conceptions of the nature of Rio Grande Pueblo social and political organization (see Spielmann 1990 and this volume), and hence the discussion of PlainsPueblo interaction is closely linked to the issues reviewed above.

A volume devoted to Plains-Pueblo interaction is thus a welcome event. It creates a context for the informative comparison of ideas and data that is essential if a wider synthesis is to be achieved. My objectives in this paper are to show: (I) that a reexamination of existing data on Pueblo settlement systems can shed new light on critical organizational issues and $(2)$ that an analysis of the changing structure of Plains-Pueblo macroregional systems in the period A.D. $1250-$ I 600 reveals previously unappreciated relationships with important implications for the nature of Pueblo political organization. The perspective developed in the first part provides the elements used to construct the model presented in the second. 
Data on the Piro (Marshall and Walt 1984) and Northern Tewa (Mera 1934) support the claim that Pueblo ethnic groups were organized into sharply bounded, multisettlement polities whose settlement systems exhibit a size hierarchy. Elsewhere I have called these polities "ethnic alliances" and hypothesized that they were governed by councils (Wilcox I984; see also Robertson 1983; M. Smith I983), leaving open the question of whether there were offices analogous to those of paramount chiefs (see Wilcox 198 ra). In contrast, Spielmann (1982, I 990) sees them as egalitarian confederacies or "big man" systems. If it can be agreed that these multisettlement polities existed, the debate should logically turn to questions about the nature of internal integration and social solidarity, and to the interactions among these entities.

In the second part of the paper, I analyze the nature of the macroregional systems in which Pueblo polities were embedded from A.D. I 250 to 1600 . I begin with a discussion of the several systems of interaction among southern Plains populations and populations on their west and east (Fig. 8.1). The absence of late prehistoric connections between Paquimé (Casas Grandes) or the Rio Grande pueblos, and Gibson Aspect sites in northeastern Oklahoma such as Spiro is documented. This lack of interaction contrasts sharply with the presence in the protohistoric period (A.D. I450-1700) of a Pueblosouthern Plains macroeconomy.

Next, I define the parameters of a hypothetical macroeconomy centered at Paquimé, arguing that it may have successfully incorporated western Plains groups from the southern Llano Estacado and West Texas. This was a century or more before the protohistoric Plains-Pueblo macroeconomy developed farther north. Disintegration of the Paquimé and Mississippian macroeconomies resulted in profound organizational changes, one of which was the emergence of a new political economy among Pueblo IV polities that soon involved Plains groups.

A Pueblo-southern Plains macroeconomy thus emerged in the mid fifteenth century that eventually integrated the Pueblos with the Fulton Aspect descendants of the Gibson Aspect peoples. I explore the possible political implications of these arrangements in an interpretation of the role of the Wichita Indian at Pecos in 154 I whom the Spaniards called Turco. I suggest that the ecological concept of "mutualistic" interaction used to explain Plains-Pueblo interaction 


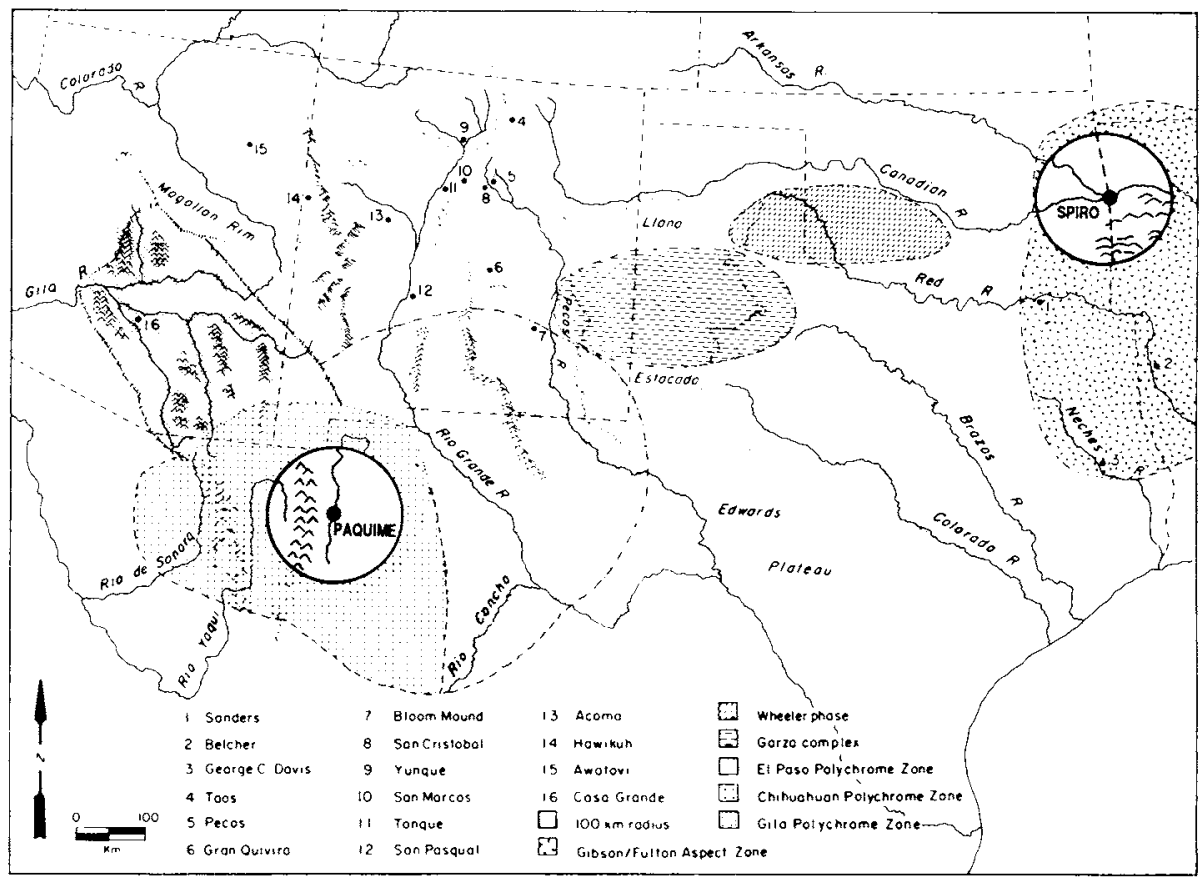

FIGURE 8. I. Cultural relationships in the Southwest and the southern Plains, A.D. I $250-1600$.

is insufficient. It needs to be redefined in cultural and political terms as part of a more complex system of human adaptation.

TWO CASE STUDIES OF PUEBLO ETHNIC ALLIANCE

The Piro

Surveys by H. P. Mera (1940) and more recently by Marshall and Walt (1984; Marshall I989), among others, have considerably clarified the structure of Piro settlement patterns during the glaze-paint period (Tables 8.I and 8.2, Fig. 8.2). In writing of the Piro and their neighbors in 1582, Espejo (Hammond and Rey 1966, 22I) commented, "They respect each other's boundaries." Archaeological data support this claim. Mera noted that

A matter of considerable interest is seen in the very marked gap between the northernmost glaze-paint village of the Piro division and that of the most southern West Tiwa [Los Lunas district] settlement in that same 
category. For a distance of some two score miles, on both sides of the Rio Grande Valley, there appears to have been good agricultural land on which it has been impossible to obtain evidence of occupation during any of the glaze-paint period. (Mera I940, I 8; emphasis added)

More recently, surveys by Marshall and Walt in what they call the Rio Medio District (Marshall I989) have documented numerous glazeware sites in the twenty-mile section north of Abo Arroyo lopposite Abeytas Pueblo, LA 780; see Fig. 8.2). Interestingly, however, though occupation in that section was dense in early glaze times, by Glaze E nearly all of these settlements had apparently been abandoned, or only a trace of occupation is indicated (Marshall 1989, Figs. I and 2). Glaze E ceramics were present in the Piro area by the early I 500 (Marshall I987, 30, 80). Correlating Gallegos's account (Hammond and Rey 1966, I03; see below) with the archaeological data suggests that only three sites, accounting for 155 "houses," were located in this boundary zone in I $58 \mathrm{I}$. Archaeological testing of the sites north of Abo Arroyo is needed to clarify just how late they were occupied and the circumstances of their abandonment.

Documents from the Espejo expedition (Hammond and Rey 1966, I74-176) report the sighting of "some small pueblos and many deserted ones" in the eight leagues north of Abo Arroyo. A pueblo at the place they called El Corvillo (Hammond and Rey 1 966, I 76) may also have been abandoned. Luxan's statements are vague on this point.

Summing up, then, current data continue to support, though in a somewhat modified form, Mera's inference of a settlement hiatus (1940, I8). During Glaze E times, from Sevilleta and San Francisco on the south to the Los Lunas-Belen area on the north, there was a more than $20 \mathrm{~km}$ settlement hiatus in which only "small pueblos" are attested in the late I 500 s. The Glaze E hiatus, a no-man's-land a day's travel long, was probably the result of the politics of threat and counterthreat or open warfare between the Piro and the Los Lunas Tiwa. While Espejo heard no reports of warfare, Hernán Gallegos, who was there a year earlier, reported that the Piro were at war with another nation "farther on" (Hammond and Rey I966, 82, 221). The abandonment of "four large pueblos in ruins" reported by Luxan in the northern part of the Piro province (Hammond and Rey I966, I73) may also have resulted from warfare. Alternatively, European diseases introduced by the Coronado or Rodriguez-Chamuscado expedition may have devastated them (Marshall 1987, I25; Marshall I989, 
Table 8.1. Glaze A Piro Settlements Along the Rio Grande

\begin{tabular}{|c|c|c|c|c|c|c|}
\hline \multicolumn{3}{|c|}{ West Side of River } & \multirow[b]{2}{*}{$\mathrm{Km}^{\mathrm{a}}$} & \multicolumn{3}{|c|}{ East Side of River } \\
\hline \multirow[t]{14}{*}{1581 Name (Houses) } & LA No. & Site Name (Rooms) & & Site Name (Rooms) & LA No. & 1581 Name (Houses) \\
\hline & & & & San Francisco (12) & 778 & Pueblo Nuevo? (20) \\
\hline & & & 6 & & & \\
\hline & & & & Sevilleta (ca. 165) & 774 & Ponsitlan $(25)$ \\
\hline & & & 7 & & & \\
\hline & 287 & Cerro Indio $(117)$ & & & & \\
\hline & 286 & Estancia Acomilla (14) & 1 & & & \\
\hline & & & 4 & & & \\
\hline & & & & Pueblo de Arena (ca. 36) & 31717 & La Pedrosa $(14)$ \\
\hline & & & 6 & & & \\
\hline & & & & Alamillo Pueblo (?) & $?$ & El Hosso $(50)$ \\
\hline & & & 8 & not located & - & Elota $(14)$ \\
\hline & 283 & El Barro $\langle 59\rangle$ & & & & \\
\hline & & & 6 & & & \\
\hline \multirow[t]{2}{*}{ Pina $(85)$} & 791 & 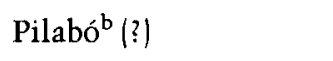 & & & & \\
\hline & & & 8 & & & \\
\hline \multirow[t]{3}{*}{ Piastla (35) } & 282 & unnamed $(180)$ & $\leftrightarrow^{c}$ & Las Cañas $(200)$ & 755 & San Juan (42) \\
\hline & & & 1 & Al Lado de las Cañas (8) & 768 & \\
\hline & & & 1 & Upper las Cañas $\{$ ca. 25\} & 31698 & \\
\hline
\end{tabular}


31744 Plaza Montoya (200)

Santiago (25)

$760^{d}$ unnamed (?)

$\leftrightarrow \quad$ Qualacú (100-200)

757 San Miguel (47)

19266 Nuestra Señora (ca. 35)

\section{7}

244 Tiffany Pueblo (ca. 40)

- Senecú (?)

487 San Felipe (45)

(Distance from San Felipe to San

Miguel: 2 leagues)

597 Milligan Gulch (200-300)

${ }^{a}$ Kilometers between adjacent sites

bLater called Nuestra Señora de Socorro.

${ }^{\text {' }}$ Sites opposite one another across the river

${ }^{d}$ Reported by Mera $(1940: 8)$ as a Group A, D, and E pueblo of undetermined size. 
Table 8.2. Glaze E Piro Settlements Along the Rio Grande

\begin{tabular}{|c|c|c|c|c|}
\hline \multicolumn{2}{|c|}{ West Side of River } & \multirow[b]{2}{*}{$\mathrm{Km}^{\mathrm{a}}$} & \multicolumn{2}{|c|}{ East Side of River } \\
\hline LA No. & Site Name (Rooms) & & Site Name (Rooms) & LA No. \\
\hline \multirow[t]{4}{*}{780} & Abeytas Pueblo $(200-300)$ & & & \\
\hline & & 20 & & \\
\hline & & & Sevilleta Pueblo (165) & 774 \\
\hline & & 9 & & \\
\hline \multirow[t]{2}{*}{287} & Cerro Indio (117) & & San Acacia Pueblo (ca. 60) & 1999 \\
\hline & & 15 & & \\
\hline \multirow[t]{2}{*}{283} & El Barro (59) & & Pueblito Pueblo (large) & 761 \\
\hline & & 6 & & \\
\hline \multirow[t]{2}{*}{ (791) } & (Pilabó) & & Pueblo Presilla (ca. 115) & 31720 \\
\hline & & 7 & & \\
\hline \multirow[t]{2}{*}{282} & unnamed $(180)$ & & Las Cañas $(200+1$ & 755 \\
\hline & & 10 & & \\
\hline \multirow[t]{3}{*}{31746} & Paragas Pueblo $(150-200)$ & & & \\
\hline & & 8 & & \\
\hline & & & unnamed $(100)$ & 758 \\
\hline
\end{tabular}


11

17

${ }^{a}$ Kilometers between adjacent sites.

${ }^{\text {b}}$ Reported by Mera (1940:8) as a Group A, D, and E pueblo of undetermined size 


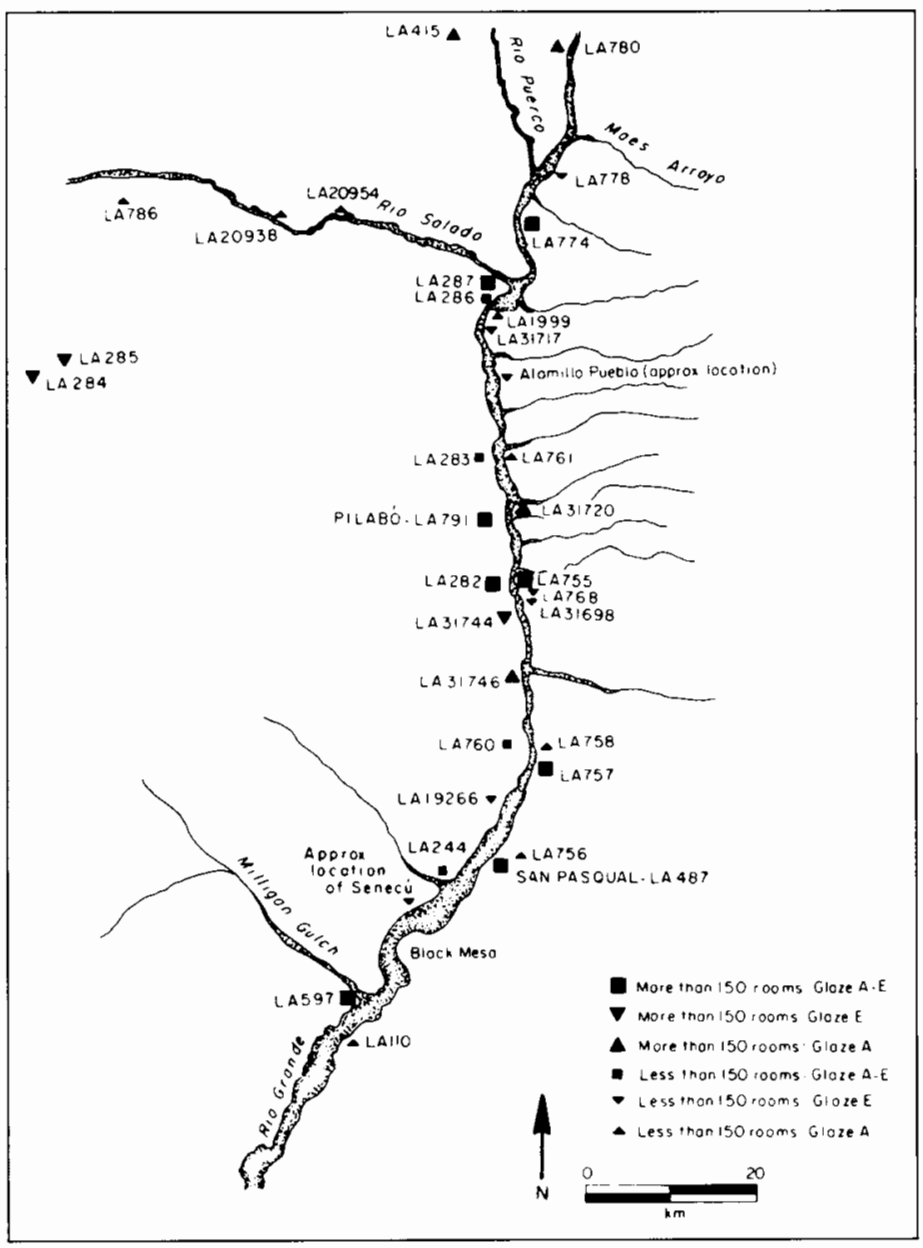

FIGURE 8.2. Piro site distribution (after Marshall and Walt I 984, I36, I40).

I6). The clustering of abandoned sites on province boundaries, however, is not well explained by the disease hypothesis.

On the Piro's southern boundary, a large no-man's-land existed much earlier. During the Late Elmendorf phase (A.D. I IOO-I300; Marshall and Walt I984), ancestral Piro populations were concentrated in highly defensible locations at the northern end of their later territory, just below the confluence of the Rio Salado and the Rio Grande. Survey west of the Rio Grande (Stuart and Gauthier I98 I; Lumbach and Kirkpatrick 1985; Roger Anyon, personal communica- 
tion, 1989) shows that the Late EImendorf settlements were but one component in a long east-west boundary that separated the Tularosa Black-on-white populations in the north from populations using El Paso Polychrome or Chihuahua polychromes to the south. The Tularosa populations had close cultural relationships with Zuni, where several I,400-room sites existed in the late I 200 (Mera 1935; Rinaldo 1964; Kintigh 1985). Later glaze-paint designs evolved out of ceramic concepts and technology developed at Zuni and Acoma (Mera I935; Wendorf and Reed 1955; Hayes I98I). The east-west boundary zone thus marks what I argue was a major economic and ideological discontinuity between the macroeconomy centered at Paquimé and a post-Chacoan Pueblo interaction sphere centered at Zuni. Supporting this position is a fact reported by Marshall: "The presence of Casas Grandes ceramic material in the Piro District is most unusual. In fact, the two Ramos Polychrome sherds found at Qualacu are the only documented Casas Grandes materials recognized to date in the Piro region" (Marshall I 987, I 25).

With the decline of Paquimé and the El Paso Polychrome settlement network in the late 1300 (see below), the Piro expanded southward along the Rio Grande during Glaze A times (A.D. 1325-I475). In general, the Glaze A settlement pattern is characterized by a series of more or less evenly spaced sets of sites that are often paired on either side of the river (Table 8. I and Fig. 8.2). The Glaze E pattern (Table 8.2 and Fig. 8.2) is similar except that a greater degree of size hierarchy in the paired sets is apparent. The site pairing may be related to irrigation methods. Espejo (Hammond and Rey I966, 220) reported that the Piro had both irrigated and rainfall-dependent fields, and he noted that "On both sides of the river there are sandy stretches extending for more than a league, naturally adapted for the production of abundant corn crops" (Hammond and Rey I966, $22 \mathrm{I}$; emphasis added). New research is needed to describe and explain the geomorphology of Piro settlement locations (Earls I987).

The settlement data reported by Marshall and Walt (1984) permit a reassessment of the correlations between archaeologically known Glaze E sites and those reported by Gallegos and Pederosa in $158 \mathrm{I}$ (Hammond and Rey 1966, I02-I09, I I 5-I20; see Fig. 8.2). In particular, I suggest that the first Piro site visited by the Spaniards, which they called San Felipe, is San Pascual (LA 487), not Milligan Gulch (LA 597), as inferred by Hammond and Rey (I966, 8I) and Marshall and Walt (1984, 248). Unlike Milligan Gulch, San Felipe 
was on the east side of the river, just as was San Pascual (Schroeder 1979, 240), and San Pascual would have been the first large Piro site encountered on the east side by people coming from the south. Most interesting is the fact that Pederosa (Hammond and Rey I966, I I 5) infers that San Felipe was the "capitol of the province" ("cabeza de la provincia"), while Gallegos (Hammond and Rey 1966, 8I) describes it as "an abandoned pueblo that had been inhabited by a large number of people" but whose three-story walls were "crumbled from the rains and seemed to have been abandoned for a long time." San Pascual, with 750 rooms, fits this description much better than does Milligan Gulch.

If San Pascual was a cabeza de la provincia, perhaps analogous to a primate center, this was so during Glaze A rather than Glaze E. By Glaze E times, San Felipe had only 45 houses, while Piña, farther upstream and on the west bank, had 85 . These data indicate that the location of the so-called primate center in the Piro settlement system shifted to a more central position between Glaze A and Glaze E times. Piña was probably the site later called Nuestra Señora de Socorro or Pilabó, which Benavides (Ayer 1965, I7) in I630 regarded as "the principal pueblo" of the Piro province. Archaeologically, this is LA 79I, which lies under modern Socorro. Mera's (1940, 8) collections indicate that it dates primarily to Glaze $\mathrm{E}$ and $\mathrm{F}$. New comparative studies to establish the ways in which Piro sites were autonomous or were functionally differentiated are needed.

The correlation of the Gallegos and Pederosa descriptions with the Glaze E Piro sites presents a new opportunity to estimate the size of the 1581 Piro population. The Spaniards give figures for the number of "houses" at each site, but they did not visit all sites /see Table 8.2). The total number of houses reported is 402 . Using the room counts for these sites cautiously (and noting the fact that much of San Pascual was abandoned), I infer that the average number of rooms per house was about 4.33. Dividing this figure into the room count of sites not visited in $\mathrm{I} 58 \mathrm{I} / 58 \mathrm{I}-78 \mathrm{I}$ rooms) yields $\mathrm{I} 34$ to I 80 additional houses, or 534 to 582 altogether in 20 Piro sites /Cerro Indio is not included since it was primarily a Glaze A site; Marshall and Walt I984, I47). If we then assume a high average household size of 8 persons (see Hammond and Rey 1966, 172-173), the order of magnitude of the Piro population in $158 \mathrm{I}$ apparently was about 4,500 people. This is considerably less than the 12,000 estimated by 
Gallegos in I58I and Espejo in I582 (Hammond and Rey I966, 82, 219). Continued archaeological study of this problem is needed.

If the Piro population in the late I 500s amounted to nearly 5,000 people and if they were politically integrated, as is argued here, then the proposition that they had a vertically differentiated political decision-making organization is supported (see Lekson I985). The fact that in both Glaze A and Glaze E times there was one Piro settlement that was twice as large as any other further supports this position. A related proposition that should now be tested is that the Piro were economically integrated and that the sites of San Pascual (in Glaze A) and Piña (in Glaze E-F) had unique functions in the socioeconomic system. We are still a long way from answering these questions, but it has been shown here that the probability that such integration and control existed is much greater than some scholars have thought.

\section{Northern Tewa}

A well-bounded polity in the northern Rio Grande valley has also been identified. H. P. Mera in 1934 published a fascinating series of maps of Biscuit-ware sites from about A.D. I400, I500, and I600. The sites are nested sets, all being present early, about half in the middle period, and about half of the latter in the last period (Mera I934, I8-2I). These relationships are summarized in Figure 8.3. Mera (1934) also noted that the perimeter of the early settlement system was marked by a series of highly defensible sites: LA 301 , $307,253,275,174,254,264,158,255,18,2$ I I 47, and 795. Subsequent excavations documented close similarities between kivas at Te'ewi (LA 252) and the seventeenth-century Northern Tewa site of Cuyamunge (Wendorf 1953, 94-96). As in the Piro case, it seems reasonable to infer that the interaction sphere indicated by a ceramic province is well correlated with a protohistoric ethnic group, in this case the Northern Tewa. Also like the Piro, a distinct settlement hiatus marked the northern Tewa boundary with other Pueblo groups:

With the desertion of the peripheral villages, on the south, before the disappearance of the A group of glazes, there appears to have formed what might be termed a "no-man's land" between Biscuit and Glaze territories. It is interesting to know that a similar retirement took place along the northern glaze-paint front in the region south of Santa Fe, and after Group C glaze times there existed a zone some twenty miles in width occupied only by the ruins of former villages. (Mera 1934, 19) 


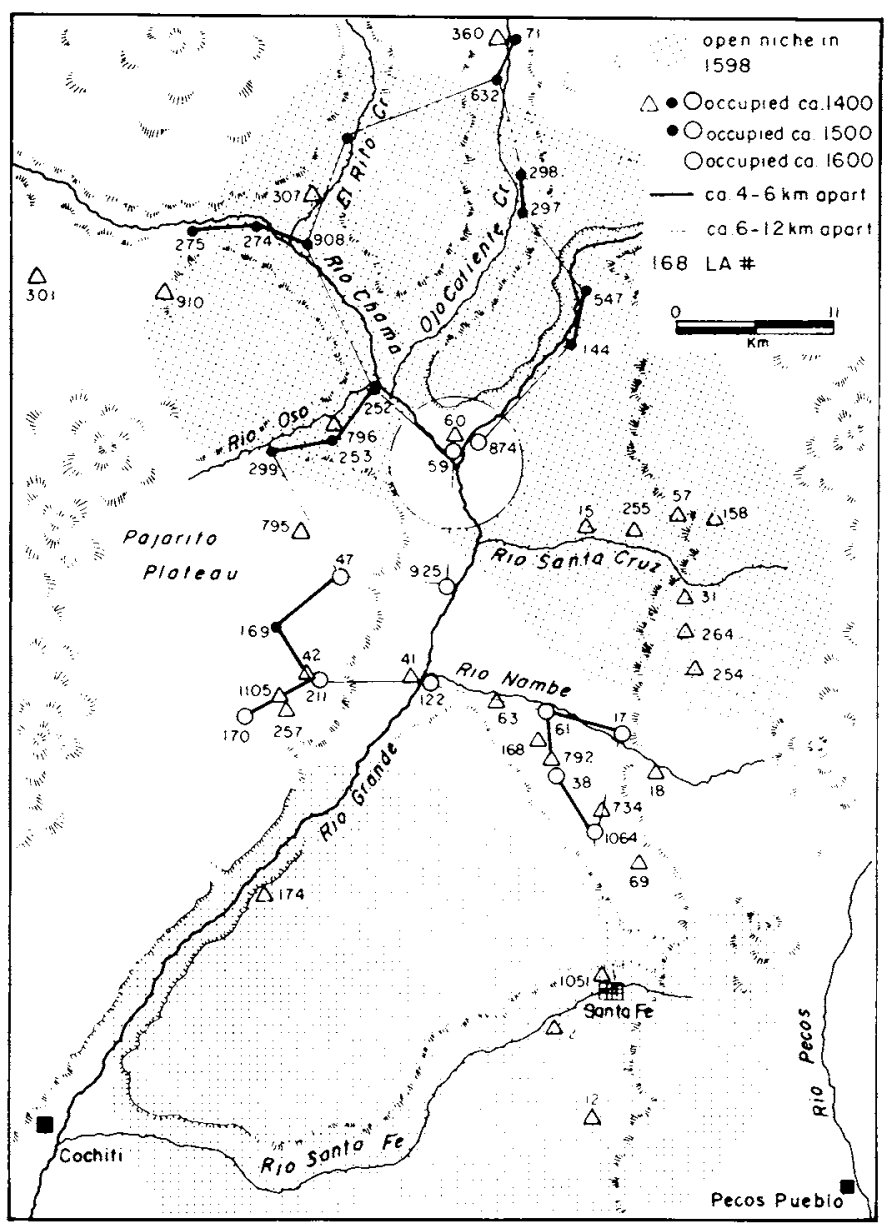

FIGURE 8.3. Northern Tewa sites in the upper Rio Grande valley (after Mera I934).

Arroyo Hondo (LA I2) was a large early site in this no-man's-land, and a recent survey in connection with its excavation (Dickson 1975 , I 979) has refined the settlement picture in this zone. Large sites like LA 12 were abandoned just as Mera inferred, and a general settlement hiatus did come about, although a few small villages continued to exist in the area during Mera's latest period (LA 7, 70, 126, 249, 6455; Dickson 1979, 35). They were on the periphery of the Biscuit settlement system, however, and any interpretation of the profound settlement changes in this zone should take this fact into account. 
Mera's Biscuit data also bring into focus a fascinating fact about early Spanish settlement patterns in the Rio Grande area. Juan de Onate established his capital at San Gabriel in Yunque pueblo (LA 59; Hammond and Rey 1953, 17). In I6 Io the capitol was moved to Santa Fe (Crouch et al. 1982). The latter is in the abandoned zone bounding the surviving pueblos, and San Gabriel coopted one of two isolated pueblos in a second abandoned zone (Fig. 8.3).

Such a location is not unprecedented. The Romans established Lyons on the Rhone in a no-man's-land between the warring tribes of Aedui and Allobroges (East 1965, 4I). Is this kind of location generally true of seventeenth-century Spanish settlement in New Mexico? By imposing "peace" on the Pueblo regional system, the Spaniards may have opened access to a large amount of productive land that both the Pueblos and they could productively exploit. Small dispersed sites were founded in the zone west of LA I 2 after A.D. I600 (Dickson I979, 35-37). New research on this issue is needed.

\section{PLAINS-PUEBLO MACROREGIONAL SYSTEMS}

The intent of the preceding discussion was $(\mathrm{I})$ to show that many of the late prehistoric and early protohistoric Pueblos were indeed organized into multisettlement polities, and (2) to suggest certain aspects of their organization. Elsewhere (Wilcox I984), I have pointed out that Taos, Picurís, Pecos, and Acoma are exceptions to this pattern, being large, isolated pueblos of about 2,000 people each /though Acoma had three small sites nearby). Acoma is a "gateway" (see Hirth I978) between the Colorado Plateau and the Rio Grande settlement networks. The other three and the Gran Quivira and Galisteo complexes are gateways to the Plains where Querecho (Apache) and Teya hunter-gatherers exchanged bison products for corn, cotton mantas, and turquoise. The cotton was grown along the Rio Grande. A multiethnic division of labor was thus involved in the exchange system, and a macroeconomy in Baugh's ( $1984 \mathrm{~b}$ ) sense is indicated (Wilcox 1984). Cotton mantas went from the Rio Grande to the eastern gateways and then to the dog nomads, and bison hides and meat moved the other way (Hammond and Rey I966,83), yet none of these populations controlled the others politically.

Spielmann (I982) and Speth and Spielmann (I983) have shown that the Pueblo's carbohydrates were necessary to the survival of the Plains bison hunters and I have argued that the meat protein was 
essential to the survival of the Pueblos (Wilcox I984). In contrast to Speth (this volume), I argue that the dog nomads visited the eastern gateway pueblos several times a year (Wilcox I984, I 45-I 46). Greencorn ceremonies during the summer may have been the occasion for regular summer visits (see Snow, this volume) when the meat and fat from June hunts were brought in (see Baugh, this volume). Hammond and Rey $(1953,400)$ report Vaquero Apache who were observed "returning from trading with the Picuries and Taos" in late September I 598" (emphasis added).

While these ideas contribute to an understanding of the Pueblosouthern Plains macroeconomy, they do not fully specify the parameters of that system or explain how it came into being. My objective in the remainder of this paper is to initiate an inquiry into these areas. In the process I show that participation by the Pueblo polities in macroeconomic systems likely required decision making well beyond the capacities observed in big-man systems.

Alex Krieger (1946) was one of the first archaeologists to evaluate Plains-Pueblo interaction systematically. His findings are a useful point of departure for a survey of current data (see Fig. 8.I):

I. Late prehistoric period, A.D. 1250-1450. Two zones of exchange are documented: $(I)$ in the north, the Late Subphase sedentary Antelope Creek sites along the Canadian River in West Texas have Glaze A pottery (Lintz, this volume); and (2) in the south, the Llano Estacado below Portales and in West Texas has ephemeral sites with Jornada brownware, El Paso Polychrome, and Chupadero Black-onwhite.

2. Early protohistoric period, A.D. I450-I600. The Antelope Creek sites were abandoned by about A.D. I500, when Athapaskan populations were intruding into the southern Plains from the north (Wilcox I98Ib; Lintz, this volume). Farther east, in eastern Texas and Oklahoma, Fulton Aspect sites of the Caddoan and Wichita confederacies have Pueblo pottery dating as early as Glaze C (Krieger I946). Interesting similarities in material culture are also present. In particular, Krieger $(1946,22 \mathrm{I}-237)$ suggests that the shouldered and carinated bowl shapes that first appear in Glaze C and D pottery may derive from a Caddoan stimulus (but see Hayes I 98 I, 96; Hayes states that prototypes of these forms were present in Rio Grande Black-on-white types). Krieger (1946, 207) also notes that the Spaniard Moscoso observed in I 542 that the Hasinai (Caddoans) possessed cotton mantas and turquoise obtained from the Pueblos. 
3. Late protohistoric period, A.D. I600-1700. While the Pueblosouthern Plains-Wichita-Caddoan macroeconomy continued, in the far southern Plains a new east-west network emerged following the establishment of silver mining settlements in Durango and Chihuahua in the mid to late I 500 . The Plains Jumano were middlemen in this system, and their annual trade fairs with the Caddoans on central Texas rivers may have served to transfer European trade goods into eastern Texas as early as I600 (Krieger 1946, 208-21 I). J. Charles Kelley (1952, I955, I986) has discussed aspects of this system in great detail, including the marvelous travels of Juan Sabeata. Neither Krieger (1946) nor Kelley $(1986,44)$ see any evidence that it existed much before 1600 .

Current data indicate that Plains-Pueblo interaction between sedentary villagers and hunter-gatherers may have begun during the late prehistoric period in the far southern Plains. Sites on the Llano Estacado may have resulted from Pueblo hunting parties venturing east for bison or other game (Krieger 1946), but it seems more likely that they indicate the activities of Plains hunter-gatherers (Collins $197 \mathrm{I}$ ). Kelley (I986, 109-- I I0) includes many of these sites in his Livermore Focus. Those populations may be in part antecedent to the people later called Jumanos. In any case, they may already have been exchanging bison products for corn with pueblo-dwelling people who lived along the Hondo River near Roswell, New Mexico (see Fig. 8. I and Speth, this volume).

Bloom Mound (J. H. Kelley r 984, 45 5-496), Rocky Arroyo (Wiseman 1985 ), and the Henderson Site (Rocek and Speth 1986) all have considerable quantities of bison bone, although Speth (this volume) suggests that the Pueblos may have been doing their own hunting. Comparative studies of faunal assemblages from these sites with those from protohistoric pueblos in which dog nomads brought in most of the bison may clarify this issue. As Spielmann (this volume) notes, if the Pueblos were hunting bison, transporting the meat and hides any distance would have been a significant problem because they lacked large dogs. Quite possibly this would result in different butchering practices from those used by dog nomads, and this might show up in the faunal assemblages.

El Paso Polychrome is the predominant painted pottery at Bloom Mound (Kelley 1984, 476-477). Jane Kelley (1984) classifies these sites in her Lincoln Phase, which has close cultural connections with sites farther northwest near Chupadera Mesa (see Mera I940, 
1943; Hayes 198I). Also present in Lincoln phase sites, however, are copper bells and a few Chihuahuan polychrome ceramics (Kelley I984, 472, 475), which indicate interaction with the hypothetical macroeconomy centered at Paquimé in northwestern Chihuahua (Di Peso I 974; see below). Seventeen sherds of Ramos Polychrome are also reported from the Greenbelt site in the Texas Panhandle (T. Campbell 1983, 67). With the abandonment of the Lincoln phase sites in about A.D. I 450, Gran Quivira became the principal southern gateway to the Plains.

The early protohistoric Pueblo-southern Plains macroeconomy replaced the system of interaction that had existed between late prehistoric Pueblos and the early Antelope Creek subphase. Antelope Creek populations became more mobile, their interactions with the Pueblos intensified, and the level of conflict increased (Lintz, this volume). Interestingly, Fulton Aspect populations on the eastern edge of the Plains were also incorporated into this system, but the earlier one did not involve the Gibson Aspect populations, such as those centered at Spiro or Sanders (Krieger I 946; Wyckoff I980; Lintz, this volumel.

Only one possible cotton textile fragment has been found at Spiro (King and Gardner I 98 I, I 37). Plains connections for Spiro have been suggested (Phillips and Brown I978, 20, 22) on the basis of bison-hair textiles, but they are rare. The issue of how much bison bone is associated with Spiro phase sites is controversial (Rohrbaugh I984, 278). Wyckoff (1980, 487-507) shows that bison could have been procured in eastern Oklahoma and reports that the amounts of bison bone are far greater in Fulton Aspect sites than in Gibson ones. On the other hand, Caddoan sherds have been found in central and southern Plains sites as far west as western Oklahoma and the Texas Panhandle (Bell I984; Drass and Moore 1987; Don Wyckoff, personal communication 1988 ; Lintz, this volume).

Spiro apparently was a gateway that linked the Mississippian macroeconomy both to eastern Oklahoma and, in some sense, to the Plains beyond (Phillips and Brown 1978; see also Story 1981). The transition between the Gibson and Fulton aspects apparently involved a disengagement with the Mississippian macroeconomy (Rohrbaugh I984, 277). A new alignment with Plains groups to the west also came about. This soon led to the emergence for the first time of a macroeconomy that linked the Wichita and Caddoans with 


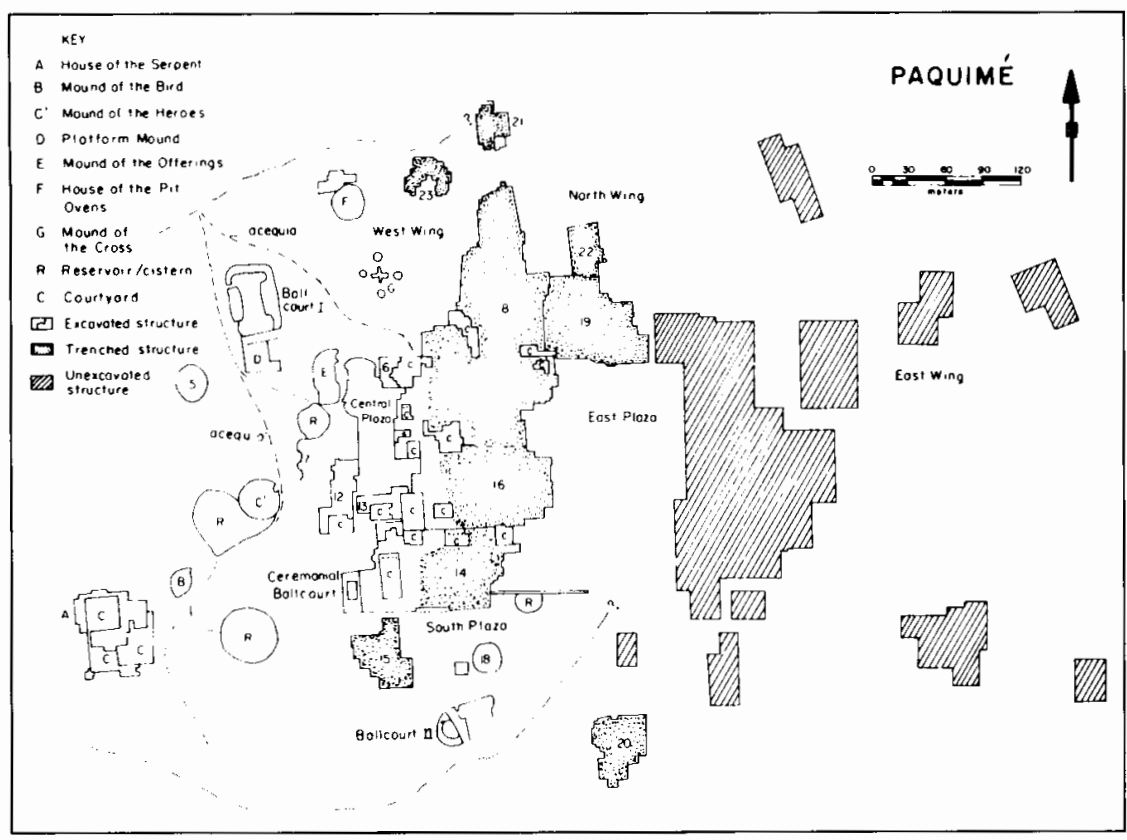

figure 8.4. The site of Paquimé, Casas Grandes, Chihuahua (after Di Peso 1974, fig. 45 I-2, and Di Peso et al. I974, fig. 21 5-5).

the Pueblos. The entry of Athapaskan populations from the north, however, apparently squeezed out the Antelope Creek populations by A.D. I 500 (Lintz, this volume).

\section{THE PAQUIMÉ MACROECONOMY}

The late prehistoric period in the southern half of the Southwest was profoundly influenced by the rise of a major center at Casas Grandes, Chihuahua. Francisco Ibarra, who saw it in ruins in 1565 , called this site Paquimé (Fig. 8.4). Excavations by Charles Di Peso (I974) showed that it was occupied during what he called the Medio period, which he dated from A.D. Io6o to I 340. However, Di Peso's dating depends on the assumption that few rings are missing from his 53 tree-ring-dated samples (see Wilcox and Shenk 1977, 65). Recent reexamination of these specimens by Jeffrey S. Dean (Ravesloot et al. I986) has shown that no sapwood remains on most of them; hence many rings are certainly missing. It is highly likely that occupation 
at Paquimé began after A.D. I I 50, that it was at its height in about I300-I350; and that it was abandoned by A.D. I 450 (see LeBlanc 1980; Carlson 1982; Lekson I984; Wilcox 1986a, 26-29).

Paquimé grew to become a site with more than 2,300 rooms, of which about 47,000 $\mathrm{m}^{2}$ was domestic space (Di Peso 1974, 4:206207 and Fig. I 34-4). Its population was perhaps 4,700 people (Di Peso et al. 1974, 4:207). If Kintigh's (1985) procedure of multiplying the number of rooms by 65 percent to account for abandonment is followed, the Paquimé population still may have exceeded 3,000 people. That appears to make it larger than any other single village in the prehistoric or protohistoric Southwest.

Paquimé also had numerous and diverse platform mounds, waterworks, large plazas, and three ballcourts (Fig. 8.4). This diversity of ceremonial facilities is unparalleled in the American Southwest, making Paquimé the most complex site known in the area. The significance of this architectural fact is multiplied by the evidence for human sacrifice and craft specialization, and the enormous quantities of valuables (shell, pottery, copper, and macaws and turkeys [for feathers]) that were found there (Di Peso et al. 1974). Indeed, Phil Weigand (personal communication, 1988) notes that the mineralogical collection documented at Paquimé is one of the most impressive "ever excavated anywhere."

The evidence at Paquimé is so unusual that Di Peso (1974) postulated the direct intervention of Mesoamerican pochteca in an effort to explain what he found. So drastic a hypothesis may be unwarranted, although some kind of Mesoamerican connection and probably ideological influence are indicated (see McGuire 1980; Mathien and McGuire 1986), and the profound implications of the presence of a center like Paquimé must be addressed.

Southwestern archaeologists have only begun to seek a reconciliation of their explanatory models with the remarkable facts documented at Paquimé (see Schaafsma 1979; LeBlanc 1983, 1986; Minnis I984, I989; Wilcox 1986b, 1988). My own working sketch (Wilcox I988) is as follows (see Fig. 8.I): Well over twice as large as any site within roo kilometers of it (Brand 1943), Paquimé by the Paquimé phase (A.D. I 300-I350) was the primate center of a local system in which other villages with similar architecture, I-shaped ballcourts, and craft specialization occurred (Di Peso 1974; Minnis 1984; Naylor I985; Steven LeBlanc, personal communication, 1985). A second zone, extending as much as 300 kilometers from Paquimé, contains 
sites whose predominant painted pottery consists of Chihuahuan polychromes or copies of them (like Babocomari Polychrome). This zone may have been integrated as a regional system centered on Paquimé. One mechanism of such integration is indicated by the ballcourts reported from several sites in this zone (R. Kelly 1963; Pailes 1980; Wilcox and Sternberg 1983; Steven Lekson, personal communication, I987; Braniff I988; Curtis Schaafsma, personal communication, I988; Paul Minnis, personal communication, I 989 ), although some of these cases are questionable.

A third zone of interaction is also apparent. After the Chihuahuan polychromes, the two most plentiful painted ceramics at Paquimé are Gila Polychrome and El Paso Polychrome (Di Peso et al. 1974). Thousands of sherds of each are present, yet the center of distribution of these types is in southern and central Arizona for the former and south central New Mexico and West Texas for the latter. Curtis Schaafsma (1974, I979) has summarized many of the arguments for interpreting the Doña Ana and El Paso phases as influenced by the rise of Paquimé. Similarly, I have analyzed the relationship of the Gila Polychrome zone to Paquimé (Wilcox 1988). Much of the Gila Polychrome at Paquimé was made on a local paste (Gloria Fenner, personal communication 1988 |, documenting the inhabitants' direct involvement with the iconography of that pottery. Interestingly, virtually no Rio Grande pottery of comparable age is present at Paquimé, and little or no Chihuahuan polychrome is found in the Rio Grande valley above San Pascual (Di Peso et al. 1974, vol. 8, Fig. 397-8; Marshall 1987, I25).

The craft specialization in copper artifacts, feathers, pottery, and agave (and quite possibly other valuables such as textiles) must have acted like a powerful magnet at Paquimé, drawing in goods and spouses from a hierarchical series of zones whose total extent may have exceeded a radius of 500 kilometers (see Fig. 8.I). Copper bells, macaws, pottery, and probably feathers and the material found in ritual caches (Brooks I 985) went out of Paquimé and serve to define the limits of the Paquimé macroeconomy. They are found throughout the Gila and El Paso polychrome zones, but interestingly, few copper bells or other Paquimé valuables are known for the Pueblo IV sites on the Colorado Plateau or in the upper Rio Grande (Sprague and Signori 1963; one bell was recovered from Pottery Mound [Linda Cordell, personal communication, I989]). A few macaws are reported from Rio Grande sites (Hargrave 1970), but none of them clearly 
came from Paquimé. All of them could have reached those sites long after Paquimé was abandoned. Pueblos were also able to acquire shell independently from Paquimé due to the development of an access route to the Pacific Coast via the Mohave River after A.D. I 250 (Warren I984). A major systemic boundary between the Paquimé macroeconomy and the Pueblo IV regional system is thus indicated. In New Mexico this boundary is marked by an extensive no-man's-land, as discussed above. In Arizona the boundary lies along the Mogollon Rim, but much interaction across that boundary has been documented (e.g., Graves 1982).

Along the middle Rio Grande below Hatch, New Mexico, the development of the Paquimé attractive forces is coincident with the aggregation of Doña Ana and El Paso phase populations into networks of small villages of 25 to Ioo rooms and the spread of their El Paso Polychrome pottery far into the plains of West Texas and the Llano Estacado (Krieger 1946; Lehmer 1948; Honea 1973; Marshall 1973; Phelps 1974). The ideological innovations and iconography that excited the populations making El Paso Polychrome are also reflected in the Jornada style of rock art (Schaafsma 1980).

One outcome of these systemic changes may have been the emergence of a mutualistic exchange between Lincoln phase Pueblos and Plains bison hunters (see above). Some of these bison products may have reached Paquimé, where faunal evidence for as many as 29 to 48 individual bison was found; Di Peso et al. (I 974, 8:242-243), however, show that those bison may have been hunted locally near Casas Grandes. Alternatively, bison meat may have arrived there via the macroeconomic network from the western Plains.

Paquimé experienced a period of decline in the late fourteenth century (the Diablo phase) and was apparently violently destroyed (Di Peso I974) before A.D. I450. Coincident with this, the village networks characterized by Gila Polychrome were abandoned, and those with El Paso Polychrome declined in scale. Two centuries later, the latter areas were occupied by Sumas in the El Paso area (Gerald I973) and Patarabueyes around the Rio Conchos junction (Kelley r986). These small-scale villagers still engaged in exchanges with Jumano groups who lived on the Plains in southern Texas (Kelley 1952, 1986). But this system appears to have been independent of the new macroeconomy that emerged in northern New Mexico and the northern half of the southern Plains in the fifteenth century. 
POLITICAL IMPLICATIONS OF THE PUEBLO-SOUTHERN PLAINS MACROECONOMY

Like the Valley of Mexico in the thirteenth century, the Rio Grande valley was a relatively vacant area that rapidly filled up with people in that same century (Wendorf and Reed 1955; Sanders et al. I979, I46-I 53; Calnek 1982). By I 350, when the power of Paquimé was receding, the Rio Grande populations and Acoma, the Zuni, and the Hopi to the west began to flourish. Pueblos of I,000 to 2,000 rooms were built, and some of them were occupied by 500 or more families (Hammond and Rey 1966, I05).

In a post-Chacoan world, new forms of organization emerged, and with them new ideological schemata. The development of a large, multivillage polity at Zuni in the late thirteenth century-perhaps a reaction, in part, to the rise of Paquimé-led to the emergence of a new ideology, expressed initially, I suggest, in St. John's and Heshotauthla polychromes and later in the Rio Grande Glaze series. The Rio Grande style of rock art (Schaafsma I980) and Pueblo IV kiva mural art are other expressions of this new ideology (W. Smith I952; Dutton I963; Hibben 1975). One dimension of these beliefs was the Kachina cult, which cross-cut the earlier kinship and sodality groupings (Schaafsma and Schaafsma 1974). Medicine and war societies similarly integrated the separate interest groups, not only within individual villages but also within village clusters (see Wilcox I984).

Once village clusters were organized into political units, partitioning the more ancient polythetic interaction networks into discrete units, a hierarchical integration of these units into larger and larger political entities became possible. That is exactly what began to happen in the Valley of Mexico (Calnek I 982), and it happened earlier in China in the Chou to Warring States periods (Granet I958). I suggest that something similar began to happen in the Rio Grande valley in the fifteenth century. The difference is that in the Rio Grande the larger political entities were highly unstable, and the Spaniards intervened before the process had gone very far.

The Galisteo Basin villages, in particular, through the monopoly of critical resources such as turquoise and the lead ore used to make glazeware (Warren I969; Warren and Mathien 1985), grew in wealth and influence. Shepard's (1942, I 965) analysis of glazeware distributions first revealed the pattern of Galisteo "dominance" in the 
fifteenth century that I am interpreting here in political terms. Pecos Pueblo, however, and others, including the Zia, I suggest, resisted and then began to compete with the Galisteo polities (see Shepard I942). Pecos began especially to compete with the Galisteo polities for control of the Plains trade. Control of agricultural land may have been another issue in Pueblo conflicts. The Pecos Indians reportedly said this to Coronado (Riley 1982, 22).

Initially, early in the fifteenth century, Plains trade apparently involved the late subphase Antelope Creek populations, but later they were replaced by Athapaskans and Teya (Lintz, this volume). Hernán Gallegos (Hammond and Rey I966, 87) reports that as late as I58I the Galisteo Indians were still actively engaged in the Plains trade, but they regarded the Plainsmen as dangerous. With good reason: in I 54 I Castañeda (Hammond and Rey I940, 257-258) was told that the Plains Teya had attacked the Galisteo sites in the 1520 , causing considerable damage. Confirming this are ceramic studies suggesting that many Galisteo sites were abandoned on the eve of Glaze E times, in about A.D. I 525 (Schroeder I979). The fact that in I54I Plains Teya were wintering "under the eaves" of Pecos Pueblo supports the view that they were allied with the Pecos.

It is by no means unlikely that Pecos participated in the attack on their rivals, the Galisteo. Castañeda reported that the Pecos Indians "pride themselves because no one has been able to subjugate them, while they dominate the pueblos they wish" (Hammond and Rey I940, 257; emphasis added). This attitude is consistent with the hypothesis of competition between these polities. The decline of the influence of the Galisteo (Shepard 1942, I 965) following a period of open warfare in the 1520 is thereby clarified. Future studies of the Galisteo sites and related data are needed to test this hypothesis.

\section{The Pecos-Quivira Connection}

The above sketch of the political economy of the Rio Grande side of the Pueblo-southern Plains macroeconomy may also help to explain why there were two Wichita Indians at Pecos in I54I. If, as I have argued, Pecos Pueblo was competing with the Tano of the Galisteo Basin for control of the Plains trade and perhaps for land, and if they were engaging in active military alliances with Plains groups, information about the volatile and violent conditions on the Plains, its political vicissitudes, who was who, and what they wanted would 
have been extremely important. The medieval Rus at Kiev were in a similar situation vis-à-vis the Polovtsy on the Steppes:

The Kievans needed an enormous amount of knowledge about the steppe and its people, whether they were fighting groups of Polovtsy or one another. To create alliances with nomads, the Kievans had first of all to know what the current alliances and hostilities were among the clans of Polovtsy. Then they had to be able to find their prospective allies, which required knowledge of their summer and winter pastures. In negotiations, there were diplomatic courtesies to be observed and elaborate ancestries to be praised. The Kievans had to be sure that the gifts they brought symbolized alliance rather than vassalage or slavery, which might have been fatal. The new allies had to have a clear understanding of each other's military capabilities to coordinate effective strategies. In short, military survival for the Kievans depended on exhaustive knowledge of steppe geography and the nomad's annual migrations, customs, taboos, genealogies, and language. (Halperin 1985,17 )

Turco, whom Mildred Wedel $(\mathrm{I} 982)$ has brilliantly shown was a Wichita Indian from Quivira, could have supplied precisely this kind of information to the leaders of Pecos. He was probably a priest, as a Spanish soldier accused him of being a magician, claiming that he had seen him "talking to the devil in an olla filled with water" (Hammond and Rey I940, 234). Ollas filled with liquid were important elements in Southeastern and Huasteca iconography (Stresser-Pean I 971 ; Phillips and Brown I978; Wilkerson I985), and the soldier may well have discovered Turco in a ceremonial act.

Quite possibly Turco was a Wichita ambassador at Pecos. That non-state-level polities were capable of negotiating with "ambassadors" is documented by Father Anastasius Douay, who accompanied LaSalle on this 1686 trip to the Caddoan Hasinai. He reported that "They have intercourse with the Spaniards through the Choumans [Jumanos] their allies, who are always at war with New Spain.... There were then some Chouman ambassadors among them who came to visit us" (Krieger 1946, 2 Io). Turco was capable of carrying out political assignments; he allegedly attempted on behalf of the leaders at Pecos to lose Coronado and his party in the Plains (Hammond and Rey 1940; Riley 1982). Although he failed in his assignment and was garroted, the Pueblos did eventually succeed in their political objectives, and Coronado abandoned New Mexico. Two generations were to pass before a new Spanish colony was established there in 1598 (Hammond and Rey I953). 
Just as there were Wichita ambassadors at Pecos, so too there may have been Pueblo ambassadors in the Plains (Wyckoff 1980, 402):

In Major County, Oklahoma, some $250 \mathrm{~km}$ west of the Moore site [near Spiro, where Cerrillos turquoise has been found; Weigand et al. 1977, 3 I ], 3 Io similar looking turquoise beads, a turquoise pendant, and 2 Io Olivella shell beads accompanied the burial of a suspected Puebloan, perhaps one of the traders [or ambassadors?] who periodically visited the Southern Plains between A.D. I 400 and 1600 (Howard and Brown 1973, 216; Riley 1978 , 57).

The activities of these individuals, which are only hinted at here, suggest the operation of a much more complex and sophisticated political system than the hypothesis of egalitarian Pueblos would allow. They also suggest that the concept of mutualistic exchange (Spielmann I 982) needs to be reevaluated in the larger context of a Pueblo-southern Plains macroeconomy (Baugh I982, I984b, I986; Wilcox 1984) that was far from static. Many new perspectives for studying protohistoric Pueblo and Plains political organization are thus suggested.

\section{ACKNOWLEDGMENTS}

Numerous people provided valuable assistance with this chapter. I would particularly like to thank Roger Anyon, the late David Baerreis, Tim Baugh, Pat Beckett, Linda Cordell, Jeffrey S. Dean, Gloria Fenner, Fran Levine, Chris Lintz, Michael Marshall, Paul Minnis, Cal Riley, Curt Schaafsma, David Snow, John Speth, Kate Spielmann, and Don Wyckoff. Debbie Tubbesing at the Museum of Northern Arizona competently typed the manuscript, Dorothy House provided ever-gracious assistance in the library, Dolly Spaulding drafted the figures, and Judi Burke and Philip Thompson provided administrative support. Emily Mead of the Bilby Research Center at Northern Arizona University made the PMTs of the figures. For the shortcomings, I alone am responsible. 


\title{
9. Economic Perspectives on the Comanchero Trade
}

\author{
FRANCES LEVINE
}

The comanchero trade-the exchange between Hispanic or Pueblo New Mexicans and Comanche groups-is documented in historic and ethnographic literature primarily from the perspective of eighteenthcentury Spanish documents or the reports of nineteenth-century Anglo-American observers. In previous papers I have attempted to view comancheros in the context of interregional Plains-Pueblo trade (Levine and Freeman 1982; Levine 1983; Levine and Winter 1987). While each presentation contained more details regarding the conduct of the trade, and each study added new data in an attempt to separate myth from historical fact, those papers did not attempt to define the economic and social conditions that sustained the comanchero trade for almost two centuries. This chapter examines those conditions.

The chapter first addresses what Hispanic New Mexicans contributed to and received from commerce with Plains Indian groups. It then considers the question of what conditions account for the apparent importance of the trade during the eighteenth and nineteenth centuries among Plains Indians and New Mexicans. Finally, the discussion focuses on the archaeological evidence relating to PlainsNew Mexican trade in the historic period. Is this trade that is so well-documented in historic records also evident in archaeological remains? If so, what can we expect to learn from the archaeological evidence that we could not learn from documents? 
THE COMANCHERO TRADE IN SPANISH COLONIAL NEW MEXICO, I 540-I 82 I

Chroniclers of the sixteenth- and seventeenth-century Spanish explorations of the Southwest recorded nomadic groups, referred to as Querechos and Vaqueros, living on the Plains and traveling to the Rio Grande to exchange meat, tallow, and hides for the produce of the sedentary Pueblos (Bolton I916, I949; Hackett 1937; Lange 1957; Hammond and Rey 1966). Elsewhere in this volume, Speth and Spielmann have proposed models to explain the longevity and benefits of the mutualistic exchange of subsistence resources between the Plains Indians and the Pueblos. Pecos Pueblo, the Salinas pueblos, and the Galisteo pueblos figured significantly in the eastwest flow of goods (Riley I978). Taos and Picurís were equally important gateways to trade in the protohistoric and historic periods.

Exchange between Hispanic New Mexicans and Plains Indians seems to have begun in the seventeenth century, building upon established Plains-Pueblo antecedents. Trade fairs were held at various Pueblo villages throughout the colonial period and served as the primary arena for exchanges between the Spaniards and the Plains Indians. Pecos Pueblo and Taos Pueblo, where a fair was officially sanctioned by the Spanish government of New Mexico in 1723 , figure most prominently in discussions of the comanchero trade (Simmons 1983).

The Taos trade fair is described briefly in a 1750 reference in which Fray Manuel Trigo remarks that the date of the fair was set for July or August by the "change of the moon" (Hackett I937, 468). Although the Spanish governors attempted to regulate the rates of exchange and the conduct of the trade fairs, Fray Pedro Serrano, reporting to his clerical superior in $176 \mathrm{I}$, was horrified by the debauchery attending the event:

When the Indian trading embassy comes to these governors and their alcaldes, here all prudence forsakes them, or rather I shall say that they do not guess how completely they lose their bearings, because the fleet is in. The fleet being in this case, some two hundred or at least fifty, tents of barbarous heathen Indians, Comanches as well as other nations, of whom the multitude is so great that it is impossible to enumerate them. Here the governor, alcaldes, and lieutenants gather together as many horses as they can; here is collected all the ironware possible such as axes, hoes, wedges, picks, bridles, machetes, belduques, and knives (for the enemy does not lack iron and these other commodities|. 
Here in short, is gathered everything possible for trade and barter with these barbarians in exchange for deer and buffalo hides, and what is saddest, in exchange for Indian slaves, men and women, small and large, a great multitude of both sexes, for they are gold and silver and the richest treasure for the governors, who gorge themselves first with the largest mouthfuls from this table, while the rest eat the crumbs. (Hackett 1937, $486-4871$

Fray Francisco Atanasio Dominguez (Adams and Chavez 1956, 252) described the Taos trade fair of 1776 , giving an accounting of the items exchanged. The Comanche brought to the trade buffalo hides, white elk skin, horses, mules, buffalo meat, and slaves. They also traded guns, pistols, powder, balls, tobacco, hatchets, and some vessels made of "yellow tin," items which they obtained from the Jumano Indians. The Jumanos were traders who ranged across Texas and who brokered trade among other nomadic Indian groups, as well as with the Spaniards and the French. One buffalo hide was the equivalent in value of an iron belduque, or knife. Two buffalo skins or a vessel such as that described above could be traded for a bridle. Meat was traded for maize or corn flour, but the equivalent quantities were not mentioned. Female slaves between the ages of $\mathrm{I} 2$ and 20 could be traded for two good horses and some trinkets, such as cloth or clothing. Male slaves were worth less.

Exchange was also an important part of the Spanish policy of bartering for peace with the native populations of the Southwest (Thomas I 940; John I975, I984). The Spanish crown maintained a delicate truce with the Apache, Comanche, and other Plains Indian groups in part by providing annual or at least regular distributions of symbolic and substantive goods. Included in the Spanish Archives of New Mexico are a number of yearly accounts of items purchased for distribution to the "allied" or "gentile" nations, as the non-Christian, nomadic Plains Indian groups were called. The items listed on these accounts include various kinds of domestic and imported textiles and garments, such as capes, shirts, cotton armor, and hats. Also listed on the inventories are knives (belduques), skewers (espetones or asadores), kettles (peroles), hatchets (achetas), griddles (comales), sugar (piloncillo), glass beads (ilos de abalorios), mirrors (espejos), and other trinkets (Spanish Archives of New Mexico [hereafter SANM] II: I9 Io; see also Boyd I974, I 7 I-2 I9; Minge I 979; Simmons and Turley I980; Levine and Freeman I982).

Hispanic trade with the Plains Indians, particularly the Comanche, 
broadened in scope after Governor Juan Bautista de Anza negotiated a long-lasting peace with the Comanche in 1786 (Thomas $1932,292-$ 342; Kenner 1969, 23-77). Among the provisions of the Comanche Peace, Governor Anza authorized gifts to be made to Comanche leaders who traveled to Santa $\mathrm{Fe}$, and he established trade between Comanche and New Mexicans at fairs to be held at Pecos Pueblo (Thomas 1932, 76, 329-332; Carroll and Haggard 1942, I35-137). He also set standards to regulate trade: two iron knives equaled one buffalo hide, and thirteen hides could be traded for an average horse (Thomas I932, 306; Kessell 1979, 406). At the fair that followed the negotiations for the Treaty of 1786 , the Comanche traded more than 600 hides, many "loads" ${ }^{\prime \prime}$ of meat and tallow, and three guns.

As a result of the Treaty of 1786 , the Comanche benefited from various forms of trade with New Mexico-the official or diplomatic trade, the marketlike exchange of the Pueblo trade fairs, and a more informal trade that arose between specific Comanche leaders and New Mexican traders. This informal trade is what is referred to by the term comanchero. The Spanish policy regarding this unofficial exchange vacillated, perhaps as the governors and villagers competed for the profits to be made from trading with the Plains Indians for hides, horses, and slaves.

The first known use of the term comanchero occurred in June I813, when it was mentioned in a document recounting the safe return of a party of traders to San Miguel del Vado, located on the Pecos River about twenty miles southeast of Pecos Pueblo (SANM II: 2492). Documents describing the goods traded between the townsmen and tribesmen are not as extensive as the records of the official exchange, but at least one colonial document (SANM II:2542) provides some discussion of the quantities of goods exchanged between comancheros and the Comanche. This document contains the proceedings of a trial that took place in 18 I 4 during which two traders were accused of stealing livestock from the Comanche. In testimony presented by the accused, each trader gives his own accounting of the goods exchanged. Although their stories differ and may not be entirely truthful, they probably reflect what each trader considered to be a reasonable and credible rate of exchange. Portions of this document are summarized below; a more complete text is found in Levine and Freeman 1982.

Juan Domingo Cordero of the Plaza of Los Ranchos de Albuquerque and Josef Manuel Gonzales of La Cieneguilla were accused of 
stealing i 8 horses and mules from the camp of a Comanche chief named Vicente. In response to this accusation, Gonzales claimed that he traded 18 serapes, I 6 bunches (manojos) of punche or native tobacco, 2 fanegas ${ }^{2}$ of provisions (bastimentos), and a hide sack of rolled tobacco (un costal de anta mediano de tabaco desmenusado) for six mares and three colts. Cordero related that he took for sale 28 serapes, I05 bunches of punche, and 3.5 fanegas of provisions, which were carried by four of his own animals and one rented from Josef Truxillo. At the rancheria of Vicente, Cordero traded some of these items for two mules, one horse, three mares, and two cargas of meat and lard, perhaps totaling about 600 to 800 pounds. Having concluded this trade, they went on to another Comanche group called the Monteños, with whom Cordero traded for more mules and horses. Cordero and Gonzales returned to their homes in May, after having traveled and traded with the Comanche for almost five months.

In the later years of Spanish rule, goods for Indian annuities became scarce. Pleas from colonial officials to the crown for more horses and arms to defend the frontier and for gifts to uphold treaties went unanswered (Thomas 1929). The comanchero trade seems to have profited from the reduction in official trade. The village of San Miguel del Vado grew significantly in the later years of Spanish rule and gradually replaced Pecos Pueblo as the focal point for HispanicPlains Indian commerce, although most of the trade took place at Comanche camps rather than in the New Mexican settlements (Kessell I 979, 436-463). Elizabeth John $(1987,543-544)$ notes a number of advantages that the Comanche gained by having New Mexicans come to the Plains to initiate trade. First, the Comanche tried to avoid European settlements after devastating smallpox epidemics swept through Comancheria in 1808 and 1816 , and second, the risks of travel across the Plains then shifted to the New Mexicans.

THE COMANCHERO TRADE IN THE MEXICAN AND AMERICAN PERIODS, I 82 I - I 873

Records in the Mexican Archives of New Mexico, such as licenses, official inquiries, and reports from alcaldes, or local government officials, document the continuity of New Mexican-Plains Indian commerce during the period of Mexican rule from I82 I to I846 /see the partial inventory in Levine and Freeman 1982 |. More widely available accounts of the comanchero trade in the Mexican period were 
written by Santa Fe Trail traders and travelers. These contemporary travelogues often focus on the picturesque aspects of New Mexican dress or their clumsy wooden carts, but many contain enough descriptive information to assemble lists of trade goods.

Thomas James traveled with a party of Missouri traders across the Plains to New Mexico in $182 \mathrm{I}$. They reached New Mexico safely but were forced to give the Comanche much of their goods in return for safe passage. James estimated that the Comanche took about \$1,000 worth of tobacco, powder, lead, calico, vermilion, and sundries (James $1962,69-70$ ). Other parties made similar "exchanges," noting the Comanche preference for a variety of goods of lesser value rather than a single item of greater value (Kenner 1969,94 ).

Josiah Gregg's I 844 description of the comanchero trade notes that the traders exchanged food and "trinkets and trumperies" for horses and mules. Gregg judged that the inventory of goods taken by a New Mexican comanchero to the Plains rarely exceeded twenty dollars in value. Bread was one of the staples carried by New Mexican comancheros and ciboleros according to Gregg and other travelers on the Santa Fe Trail.

In the vicinity of Bosque Redondo in I 832, Albert Pike met a party of Hispanic New Mexicans returning from Cañon del Rescate near present-day Lubbock, where they had traded bread, blankets, punche, and beads for buffalo robes, bearskins, and horses (Weber 1967, 40$4 \mathrm{I}$ ). With the exception of the bearskins (to which this is the only reference), these lists of trade goods are not very different from items reported in colonial accounts of the trade. Horses, hides, and buffalo robes continued to be the goods obtained in trade by the New Mexicans.

Artist George Catlin visited Comanche and other Plains Indian camps on the Texas portions of the Canadian, Red, and Washita rivers in I 834. Among the portraits and landscapes that he painted, he recorded a few details indicating trade. He was greatly impressed by Comanche horsemanship, recording in his journal that the Comanche scout who rode out to meet the party of dragoons with whom he was traveling used a Spanish bit and spurs (Catlin 1973, 56). His portrait of "The Little Spaniard" shows the subject holding metaltipped arrows and a lance and wearing what appears to be a sheathed knife. This portrait illustrates another aspect of contact between the Comanche and the Hispanic New Mexicans. "The Little Spaniard" was a half-breed whose Comanche name was His-oo-san-ches. 
As the Mexican period drew to a close, the terms of the Comanche peace of 1786 were being strained by pressures from the expanding American frontier. Kenner (I969, 96-97) believes that the transition in the comanchero trade from the traditional exchange of Plains goods for Rio Grande valley produce to a situation that Anglo-Americans described bluntly as a cattle-rustling operation began in the later years of the Mexican period. He places the blame on unscrupulous Anglo-Americans who introduced guns and whiskey into the exchange. This was an important factor, but it was not the principal cause. The conflict between Anglo-Americans and comancheros was tied to larger issues, among them the increasingly competitive market for valuable buffalo hides, the land grab justified by the doctrine of Manifest Destiny, and the potential threat that an alliance of New Mexicans and Plains Indians posed to Anglo commercial enterprise on the western frontier. As the American frontier moved west and Hispanic settlements advanced east of the Pecos River, the Plains Indians were caught in the conflict.

Diaries and accounts written by soldiers and traders who entered New Mexico with the Army of the West in I846 confirm that the comancheros were still engaged in the exchange of traditional goods (Whipple I 853-54; Gregg I 954 [1844]; Galvin 1970). From just buffalo meat, hides, and horses, however, the traded expanded to include increasingly abundant cattle.

Kenner ( 1969 ) provides a summary of the trade that has been the most widely quoted source of information on the Plains Indian-New Mexican trade. Most of the literature of the period regards the comancheros as more of a curiosity than a threat. Whipple (1853-54) provides some ethnographic data on Plains Indian-New Mexican trade. He lists flour, biscuits, sugar, hard bread, and tobacco as the principal goods carried by Hispanic and Pueblo Indian comancheros and exchanged for horses and buffalo robes. He also describes other items and ornaments that were probably received in trade by the Kiowa and Comanche, including brass nails, metal arrow points, brass rings, silver buckles, medallions and crescent-shaped ornaments, brass wire bracelets, and colored beads.

Cattle theft became so overwhelming in the latter part of the I $860 \mathrm{~s}$ that the military increased patrols throughout eastern New Mexico and West Texas. The records of the Indian Depredation Cases in the U.S. Court of Claims include depositions of former comancheros detailing the logistics by which cattle rustled from Texas ranches were 
driven to New Mexico for sale and implicating soldiers and officers from Fort Bascom in the thefts (Medina I893; Tafoya I 893).

One picket stopped a party of New Mexican traders traveling to the Comanche camps without a permit and returned them to Fort Bascom. The inventory of goods that they carried gives a complete listing of what may have been a typical load carried to the Plains in the later days of the trade:

200 pounds of cornmeal, 500 of Mexican hard bread, 35 or 40 butcher knives, 9 files, vermillion, a lot of shirts, some red and white flannel, one vest, some iron hoops, ducking and calico, shelled corn, tea, sugar, flour, letter paper, candy, one regalia, one box of army caps (Ioo), about 400 percussion caps (small), several pounds of lead, about 5 pounds of powder, and 16 elongated balls 58 caliber. (Kenner $1969,178-179$ )

The Americans, like the Spanish government, tried various licensing procedures to control the trade, but they too failed. When the comanchero trade was finally quashed in 1872 , it was due to the combined efforts of vigilantes and the military and to the effects of the buffalo slaughter of the I87os. Most of the Comanche who had been participants in the trade between New Mexico and the Plains were settled on a reservation near Fort Sill, Oklahoma, by I 873 (Wallace and Hoebel 1952, 326-3281.

\section{SUSTAINING MECHANISMS OF THE COMANCHERO TRADE}

To understand the conditions that may have sustained the comanchero trade for more than two centuries, it is necessary to look at the benefits derived by all of the participants in the trade. Most historical accounts of the comanchero trade repeat the descriptions offered by Josiah Gregg (Gregg I 954 [I 844]) or simply refer to the secondary materials such as Haley (1935, 1953) or Kenner (1969). These discussions characterize the trade from the perspective of Hispanic and AngloAmerican traders and fail to address the importance of the trade among the Comanche and the Pueblo.

A recent doctoral dissertation by Thomas Kavanaugh (I 986 ) offers some insights into the function of trade with the Europeans for the Comanche. First, Kavanaugh revises the standard Comanche ethnography as presented by Wallace and Hoebel (1952), pointing out the glaring omissions of historical context contained in their study. $\mathrm{He}$ then reanalyzes primary and secondary accounts of Spanish-Comanche diplomacy and later contacts between Texan and American fron- 
tier institutions and the Comanche. He recognizes various contexts of Comanche-European trade, comprising (I) the official or diplomatic sphere; $(2)$ the annual, regulated trade of the Taos, Picurís, and Pecos trade fairs; (3) trading posts established by French, Texan, and later American traders in various parts of Comancheria; and $|4|$ the individual trade partnerships that arose between Comanche leaders and New Mexican comancheros.

Kavanaugh maintains that the Comanche moved south into New Mexico and the southern Plains, seeking to control the lucrative horse and hide trade established between New Mexican officials and the Apache in the seventeenth century. He believes that Comanche leaders defined their positions of authority through the acquisition of symbolic artifacts obtained through the official trade and maintained their dominance largely by controlling access to the other contexts in which trade took place. Canes, medallions, capes, and fine fabrics were among the items listed on Spanish accounts of presents made annually to the allied Comanche. Tobacco and sugar were also listed among the items distributed to Comanche leaders, perhaps indicating that these items too had symbolic value. The trade partnerships that existed between individual Comanche leaders and New Mexican traders gave the Comanche "trinkets" that could be distributed among their followers, thereby reinforcing the status of the leaders who controlled access to the trade goods.

Kavanaugh's analysis of Comanche political organization in the nineteenth century implies that Comanche leaders controlled the scheduling of informal trade and the amount and kind of resources contributed to the comanchero trade. Neither Kavanaugh's analysis nor my own has found that food items, other than the bread mentioned by nineteenth-century travelers, were critical commodities in Plains-New Mexican trade in the historic period.

Kavanaugh's discussion also points out that the symbolic artifacts obtained through the diplomatic trade speak to the larger political drama taking place on the southern Plains throughout the eighteenth and nineteenth centuries. The geographical position of Comancheria, or the extent of Comanche dominance, in this time period touched on the frontiers of American, French, and Spanish claims (John 1975). Comanche leaders were adroit manipulators of their strategic position, using their access to goods and alliances from the various world powers for their own advantage. For the Comanche, the official and unofficial trade gave them power beyond their own society. 
Through their participation in the comanchero trade, Pueblo and Hispanic New Mexicans gained valuable hides, horses, slaves, and livestock-goods that were needed for domestic comforts in New Mexican settlements. Economic reports for the colonial period in New Mexico such as that of Fray Atanasio Dominguez of 1776 (Adams and Chavez I956), Anza's report prepared in 1786 (Thomas I932), Chacon's report of 1803 (Simmons I985), and Pino's report to the Cortes in 1812 (Carroll and Haggard 1942) stress the conditions of deprivation that troubled New Mexican settlements. The absence of formal markets apart from the trade fairs fostered informal trade among and between Pueblos, Hispanics, and nomadic Indians.

Hides obtained in trade from the Plains Indians by the frontier settlers of New Mexico were also part of the exports from New Mexico to Mexico. The skill of the Apache and Comanche in tanning and processing hides was noted by contemporary sources (Hackett I937; Carroll and Haggard I 942) as was the promise of financial success for enterprising New Mexicans who participated in the trade. American observers who arrived in New Mexico with the opening of the Santa Fe Trail in $182 \mathrm{I}$ reported that hides, furs, and pelts were used by New Mexicans for clothing, furnishings, and food (Weber I971, 30). To quantify how much of these resources was obtained in trade with the Comanche or other Plains groups and how much was hunted and processed by Pueblo and Hispanic New Mexicans directly is more difficult.

Surviving trade invoices for the Spanish and Mexican periods give some impression of the importance of hides in the exports to Mexico. The mission supply train of I 639 carried 122 painted buffalo hides, 198 chamois skins (gamuzas), and an unknown number of finished leather jackets, shirts, and breeches (Bloom I935). Governor Mendizabal exported I, 300 deerskins and some buffalo hides to Parral in I660 (Weber I97 I, 20). During the residencia of Mendizabal in I664, his possessions included I, 200 antelope skins and four bundles of elk hides (Weber 197I, 20-2I). After the reconquest of New Mexico in 1696 , Governor Vargas sought to reestablish the hide trade with the Apache, and he received gifts of buffalo skins and an elk hide tent during the negotiations (Weber I97 I, 22).

Comanches are reported to have brought more than 600 hides to Pecos for trade during the negotiations on the Treaty of 1786 (Thomas I932, 26). Kavanaugh $(1986,253)$ reports an annual income of about $\$ 10,000$ for the Comanche of the Oklahoma Agency in I 856 derived 
from the sale of the meat and hides of 30,000 buffalo, 2,000 deer, r,ooo elk, and 500 bears. The dollar amount may not be reliable, however, and in any case the return in status and power to individual Comanche leaders from other aspects of the trade may have outweighed the actual monetary value of the transactions.

For Pueblo New Mexicans the comanchero trade may have brought more than economic resources. Ford (I972a, 26-3I; Ford 1983) describes trade between the Comanche and the Tewa, noting that in this exchange the Tewa acquired certain ritual paraphernalia made of buffalo hides, bone, and hair that they might not otherwise have been able to obtain.

The comanchero trade persisted for more than two centuries in the face of changing political and economic conditions. Thomas D. Hall ( 1986, I987a, I987b) maintains that the comanchero trade collapsed when the "ethnic niche" that had existed for them in the Spanish period was eliminated by American pacification of the Comanche. While I question the use of the term comanchero to denote ethnic status, certainly the pacification of the Comanche was an important factor in the collapse of the trade. More important, comancheros had filled an economic niche in the Spanish period that was destroyed by the expanding mercantilism of the Mexican and American periods.

The extent to which the Plains Indian groups or New Mexicans relied on the trade to meet subsistence needs is an area of inquiry in which archaeological studies may be important. To date, however, simply finding and documenting sites of the historic period have been difficult.

\section{ARCHAEOLOGICAL EVIDENCE OF PLAINS - NEW MEXICAN TRADE}

Informally, amateur and professional archaeologists working on the southern Plains have raised the question of what a comanchero site might look like. Documentary evidence indicates that the small amount of goods taken by trading parties could be assembled from even the minimal stores that were available in frontier villages, since it was neither quantity nor quality but variety that ensured success in the comanchero trade. The amount and type of goods carried by traders, and the time spent traveling to and among Comanche camps, would seem to mitigate against the likelihood of finding specific sites where exchanges took place. 
Items that clearly document Pueblo and Euro-American trade have been recovered from historic Plains Indian burials and archaeological sites in the Texas Panhandle. Word and Fox $(1975,46-47)$ summarize the grave goods found with 13 historical Plains Indian burials, describing horse gear, bracelets, and glass beads as the most common accompaniments. Cloth fragments, textiles, and other items of jewelry were also commonly found. Domestic objects such as kettles, kegs, utensils, and tools were less frequently recovered. The curation of these items as burial goods suggests their importance in the culture of Plains Indian groups but does not answer the question of how these items were acquired.

Neither the comanchero trade routes between New Mexico and the Texas Panhandle nor the identified comanchero rendezvous points in either state have been systematically surveyed for archaeological evidence of the trade. Reconnaissance surveys and salvage excavations have recorded sites containing evidence of Plains-Pueblo trade, some of which have been called comanchero sites. These sites are discussed below. Levine and Freeman (I982) reviewed archaeological field notes and excavation reports on file at the Panhandle-Plains Historical Museum in Canyon, Texas, the Texas Archaeological Research Laboratory in Austin, and the Laboratory of Anthropology of the Museum of New Mexico to determine the criteria by which sites have been labeled "comanchero sites."

Hatch's Ranch (LA 4976), located on the Gallinas River near Chaperito, New Mexico, is the only site in the extensive files at the Laboratory of Anthropology specifically designated as a "comanchero" site. The archaeological remains have not been systematically recorded, but the importance of Hatch's Ranch as a staging area for comancheros is well recorded in the historical literature. The settlement at Hatch's Ranch served both as a military garrison and as a supply post for a small group of Hispanic and Anglo comanchero traders who tried to monopolize the trade between about I 866 and I867 (Kenner 1969, I58-I6I). In this case, the identification of Hatch's Ranch as a comanchero site is based on historical accounts rather than on any particular characteristics of the artifact assemblage or architectural remains.

Site files at the Panhandle-Plains Museum and the Texas Archaeological Research Laboratory describe a number of tipi ring sites and campsites containing lithic materials, Pueblo and Plains ceramics, and metal tools. These sites have been identified as historical Plains 
Indian campsites (Levine and Freeman I982). Notes on many of the site forms suggest that the Pueblo ceramics and metal items are the remains of comanchero activities that are historically documented in the area.

The Merrell-Taylor site, located near the comanchero trading grounds of Quitaque on the Pease River in Floyd County, Texas, is reported to have been a comanchero site (Guffee I976). The site contains the remains of four dugouts, an acequia, or irrigation ditch, and an impressive artifact assemblage, including stone tools, metal lance points, muzzle-loading rifles, pistols, and kitchen artifacts (Guffee I976). Some of the items, such as the arms, an iron eyehoe, and some saddle conchos, are similar to trade items recovered from historical Plains Indian burials excavated throughout the Panhandle (Newcomb 1955; Suhm 1962; Ray and Jelks 1964; Word and Fox 1975). Twenty-six sherds of micaceous utility ware were described as being similar to the micaceous ceramics now produced at Taos and Picurís (Guffee 1976, 40). There is no discussion of how these ceramics compare with micaceous ceramics manufactured by various Apache groups in the historic period. An iron lance point was also identified as a New Mexican trade item (Guffee I 976, 50). No other trade materials specifically derived from New Mexico were identified, but because of the presence of corner fireplaces in three of the dugouts, the excavators suggest that the site was occupied by Hispanics (Guffee 1976, 50).

The Merrell-Taylor site is similar to one near Jayton, Texas, described by Ranald S. MacKenzie in 1872 (E. Wallace 1964, 1967; Carter I969). Guffee (1976, 50-5I) argues that the Merrell-Taylor site could have been a comanchero trading station, since the majority of artifacts date between $\mathrm{I} 865$ and I 885 , well within the period of documented comanchero activities near Quitaque. He also points out that the settlement was obviously planned for a long-term occupation, given the expenditure of time and labor involved in the building of four structures and the excavation of an acequia. Such a commitment seems to contradict the more expedient nature of the comanchero trade. He suggests a second, and perhaps a longer, occupation by a group of Hispanic New Mexicans who moved into the Texas Panhandle as part of the expansion of sheepherders, or pastores, in the 1870 s and in 1882 (Rathjen I973; Taylor 1976, 1980).

Excavations of tipi ring sites and historic campsites in New Mexico and Texas have yielded extremely limited artifact assemblages, 
which has made the dating, ethnic affiliation, and function of many campsites problematical (Levine I984). Surface recording of sites suspected to be historic camps is not sufficient, as shown by recent excavations in the Texas Panhandle. The Sand Pit site, located in Tule Canyon and now flooded by Lake MacKenzie, contained a large number of shallow hearths and an assemblage of glass trade beads, Pueblo ceramics, and iron tools identified as fleshers for hide processing (Hughes and Wiley I978, 233-235). The site appears to be a campsite, most likely a Comanche occupation, used for hide processing.

\section{SUMMARY AND CONCLUSIONS}

Historical sources have stressed the importance of the comanchero trade in supplying colonial New Mexicans with much-needed hides, horses, and buffalo products. The preponderance of evidence from historical sources seems to indicate that the comanchero trade was an economic strategy that was sustained for more than two and a half centuries by supplying commodities to New Mexican settlements and export markets in Mexico. It seems likely that the availability of and demand for hides sustained the comanchero trade until it faced more serious competition from the larger-scale buffalo hunts of the American hunters. Gregg's description of the comanchero trade as being based on an exchange of "trinkets and trumperies" fails to consider both the place of otherwise inaccessible European goods in Plains Indian cultures and the strategic location of nomadic groups in European and American competition for control of access, land, and resources on the southern Plains. Likewise, Kenner's emphasis on cattle rustling and the whiskey trade presents a view of the comanchero trade in its decline, which the expansion of the American frontier aided and abetted.

The comanchero trade was not an economic specialty that would have necessitated the construction of specialized site complexes or facilities in large settlements. The identification of comanchero sites probably cannot be based on a complex of archaeological attributes. Rather, the inference can only be made based on associations drawn from historical documents, site locations, and the dating of artifact assemblages. The comanchero trade seems to have been one of the many economic activities that Hispanic and Pueblo New Mexicans used to support a broad-based subsistence economy and to extend 
the range of resources available to them by participating in interregional trade networks.

\section{NOTES}

I. Although I have not seen the original Spanish text used by Thomas, I suspect that the loads of meat were referred to as cargas. The carga was a Spanish unit of measure for which there was no set standard. Barnes et al. (I98I, 73) report that in the sixteenth century a carga was that load which an Indian could carry, or about 50 pounds. In the eighteenth century a carga was the load carried by a mule. They compute a mule load at about 308 pounds, although a carga of corn might weight 304.4 pounds and a carga of wheat or flour 329.8 pounds. Josiah Gregg, reporting on freighting in New Mexico between about I $83 \mathrm{I}$ and I 844 , observed New Mexican arrieros loading pack mules with loads of between 300 and 400 pounds (Gregg 1954 [1844], 127-I3 I].

2. As a unit of weight, a fanega was just over roo pounds of corn or about 83 pounds of wheat or flour. As a unit of volume, a fanega is most often computed as I. 575 bushels (Barnes et al. I98I, 69-7I). 



\section{Bibliography}

Adams, Eleanor B., and Fray Angelico Chavez

I956 The Missions of New Mexico, I776. University of New Mexico Press, Albuquerque.

Adams, S. Charles

I979 Cold air drainage and length of growing season in the Hopi Mesa area. Kiva 44:285-296.

Addicott, J. F.

I984 Mutualistic interactions in population and community processes. In A New Ecology: Novel Approaches to Interactive Systems, edited by P. Price, C. Slobodchikoff, and W. Gaud, 437-455. Wiley, New York.

I985 Competition in mutualistic systems. In The Biology of Mutualism, edited by D. H. Boucher, 217-247. Croom Helm, London.

Akins, Nancy J.

I982 Perspectives on faunal resource utilization, Chaco Canyon, New Mexico. New Mexico Archeological Council Newsletter 4 (5-6):

Allen, Jim $23-28$.

I984 Pots and poor princes: A multidimensional approach to the role of pottery trading in coastal Papua. In The Many Dimensions of Pottery, edited by S. E. van der Leeuw and A. C. Pritchard, 407463. Albert Egges Van Giffen Instituut, Universiteit van Amsterdam, Amsterdam.

Allen, Joel A.

I 877 History of the American bison, Bison americanus. United States Geological and Geographical Survey of the Territories, Annual Allen, William C. Report 9, pt. 3, pp. 443-588. Washington, D.C.

I 977 Present and past climate. In Settlement and Subsistence Along the Lower Chaco River: The CGP Survey, edited by C. A. Rehrer, I 27-I 37. University of New Mexico Press, Albuquerque. 
Anderson, R. M., and R. M. May

I 982 Coevolution of hosts and parasites. Parasitology 85:4 I I-426.

Anschuetz, Kurt F.

I984 Prehistoric Change in Tijeras Canyon, New Mexico. M.A. thesis, University of New Mexico, Albuquerque.

Arnold, Dean E.

I985 Ceramic Theory and Cultural Process. Cambridge University Press, Cambridge.

Ayer, Mrs. Edward E., trans.

I965 The Memorial of Fray Alonso de Benavides, I630. Reprint. Horn and Wallace, Albuquerque.

Bailey, Garrick A., and R. G. Bailey

I982 Historic Navajo Occupation of the Northern Chaco Plateau. University of Tulsa, Tulsa.

Bailey, Robert C.

I 985 The Socioecology of Efe Pygmy Men in the Ituri Forest, Zaire. Ph.D. diss., Department of Anthropology, Harvard University, Cambridge, Mass.

I988 The significance of hypergyny for understanding subsistence behaviour among contemporary hunters and gatherers. In Diet and Subsistence: Current Archaeological Perspectives, edited by Brenda V. Kennedy and G. M. LeMoine, 57-65. Proceedings of the I9th Annual Chacmool Conference. University of Calgary Department of Archaeology, Calgary.

Bailey, R. C., and R. Aunger, Ir.

I 989 Net hunters vs. archers: Variation in women's subsistence strategies in the Ituri Forest. Human Ecology 1 7:273-297.

Bailey, R. C., G. Head, M. Jenike, B. Owen, R. Rechtman, and E. Zechenter I 989 Hunting and gathering in tropical rain forest: Is it possible? American Anthropologist 91:59-82.

Bailey, Vernon

I97 I Mammals of the Southwestern United States (with Special Reference to New Mexico). Dover Publications, New York.

Baker, Ele

I940a WPA, West Texas State College Archaeological Project WP- I 3202. Second Quarter, I 940 Quarterly Report for April I to June 30. Report on file at Panhandle-Plains Historical Society, Canyon, Tex.

I940b WPA, West Texas State College Archaeological Project WP-I 3202. Third Quarter, I940 Quarterly Report for July I to September 30. Report on file at Panhandle-Plains Historical Society, Canyon, Tex.

Baker, Ele M., and Jewel A. Baker

I939 (Second) Quarterly Report, West Texas State College--WPA, Archaeological Project. Manuscript on file at the Panhandle-Plains Historical Society, Canyon, Tex.

I940 WPA - West Texas State College Archaeological Project. Quar- 
terly Report, January I, I 940 to March I, 1940. Manuscript on file at the Panhandle-Plains Historical Society, Canyon, Tex.

I94 I Final Report Archaeological Survey-O.P. 665-66-3-404, State Application 30976. Manuscript on file at the Panhandle-Plains Historical Society, Canyon, Tex.

Bamforth, Douglas B.

I988 Ecology and Human Organization on the Great Plains. Plenum, New York.

Bandy, Phillip

I976 Lithic Technology: A Reconstruction of A Northern Texas Panhandle Archaeological Assemblage. M.A. thesis, Texas Tech University, Lubbock.

Barnes, Thomas C., Thomas H. Naylor, and Charles W. Polzer

1981 Northern New Spain: A Research Guide. University of Arizona Press, Tucson.

Basso, K. H., ed.

I97 I Western Apache Raiding and Warfare: From the Notes of Grenville Goodwin. University of Arizona Press, Tucson.

Bates, Daniel G., and Susan H. Lees

I 977 The role of exchange in productive specialization. American Anthropologist 79 (4): $824-84 \mathrm{I}$.

Baugh, Timothy G.

1982 Edwards I (34BK2): Southern Plains Adaptations in the Protohistoric Period. Studies in Oklahoma's Past, No. 8. Oklahoma Archaeological Survey, Norman.

I984a The physical and cultural setting of the mixed grass prairie. In Archaeology of the Mixed Grass Prairie, Phase I: Quartermaster Creek, edited by Timothy Baugh, I-32. Archaeological Resource Survey Report 20, Oklahoma Archaeological Survey, Norman.

I $984 \mathrm{~b}$ Southern Plains societies and eastern frontier Pueblo exchange during the protohistoric period. Papers of the Archaeological Society of New Mexico 9:154-I67.

I986 Culture history and protohistoric societies in the southern Plains. In Current Trends in Southern Plains Archaeology, edited by Timothy G. Baugh, I67-187. Memoir 21. Plains Anthropologist 3 I $($ I I 4 ), pt. 2.

Baugh, Timothy G., and Frank W. Eddy

I 987 Rethinking Apachean ceramics: The I985 Southern Athapaskan Ceramics Conference. American Antiquity 52 (4): 793-798.

Baugh, Timothy G., and Fred W. Nelson, Jr.

I987 New Mexico obsidian sources and exchange on the southern Plains. Journal of Field Archaeology i 4 (3): 313-329.

I988 Archaeological obsidian recovered from selected North Dakota sites and its relationship to changing exchange systems in the Plains. Journal of the North Dakota Archaeological Association $3: 74-94$. 
n.d. Obsidian Studies at Landergin Mesa (4 $\mathrm{IOL}_{2}$ ). Manuscript on file at the Texas Historical Commission, Austin.

Baugh, Timothy, and Fern Swenson

I980 Comparative trade ceramics: Evidence for the Southern Plains Macroeconomy. Bulletin of the Oklahoma Anthropological Society 29:83-102.

Baugh, Timothy G., and Charles W. Terrell

I982 An analysis of obsidian debitage and protohistoric exchange sys. tems in the southern Plains as viewed from the Edwards I Site (34BK2). Plains Anthropologist 27 (95): I-I 7.

Befu, Harumi

I977 Social exchange. Annual Review of Anthropology 6:255-28I.

Bell, Robert E.

I973 The Washita River focus of the southern Plains. In Variation in Anthropology: Essays in Honor of John C. McGregor, edited by Donald Lathrap and J. Douglas, I7 I-I 87. Illinois Archaeological Survey, Urbana.

I984 The Plains Villagers: The Washita River. In Prehistory of Oklahoma, edited by R. E. Bell, 307-324. Academic Press, New York.

Bell, Willis H., and Edward F. Castetter

I937 Ethnobiological Studies in the American Southwest, V: The Utilization of Mesquite and Screwbean by the Aborigines in the American Southwest. University of New Mexico Bulletin 3 I4, Biological Series $5(2)$ : $1-55$.

Benavides, Alonso de

I9 6 The Memorial of Fray Alonso de Benavides. Translated by Mrs. Edward Ayer, annotated by Frederick Hodge and Charles Lummis. Privately printed, Chicago.

Berry, Michael S.

I985 The age of maize in the Greater Southwest: A critical review. In Prehistoric Food Production in North America, edited by R. I. Ford, 279-307. University of Michigan Museum of Anthropology, Anthropological Papers 75. Ann Arbor.

Blackburn, Roderic $\mathrm{H}$.

I982 In the land of milk and honey: Okiek adaptations to their forests and neighbors. In Politics and History in Band Societies, edited by Eleanor Leacock and Richard B. Lee, 283-305. Cambridge Uni-

Blakeslee, Donald J. versity Press, Cambridge.

I 975 The Plains Interband Trade System: An Ethnohistoric and Archaeological Investigation. Ph.D. diss., Department of Anthropology, University of Wisconsin, Milwaukee.

Blanton, Richard, and Gary Feinman

I984 The Mesoamerican world system. American Anthropologist 86:703-705. 
Bloom, Lansing B.

r935 A trade invoice of I638. New Mexico Historical Review 2 (4): $369-379$.

Bohrer, Vorsila L.

I985 Pilot Ethnobotanical Investigations at Two Southwestern Oklahoma Archaeological Sites of the Washita River Focus, 34 WA2 and $34 \mathrm{CU}_{27}$. Report prepared for the National Science Foundation.

I986a Plant Remains from an Early Plains Village in South Central Oklahoma: $34 \mathrm{ML}-3$. Report submitted to the Oklahoma Archaeological Survey.

I986b Plant Remains from Western Oklahoma: Linville II (34RM-492). Report submitted to the Oklahoma Archaeological Survey.

1987a Ethnobotanical Investigations at the Duncan Site, Oklahoma (34WA2). Report 4 submitted to the Oklahoma Archaeological Survey.

r 987 b Ethnobotanical Remains from the Miller Site, Oklahoma (34EL25). Report 5 submitted to the Oklahoma Archaeological Survey.

Bolton, H. E.

I916 Spanish Exploration in the Southwest, 1542-1706. Charles Scribner's Sons, New York.

I949 Coronado: Knight of Pueblos and Plains. University of New Mexico Press, Albuquerque.

Booker, Rick, and Jeff Campbell

I978 An excavation report on site 4ILU6: Slaton Dump site. Bulletin of the Southern Plains Archeological Society 4:19-37.

Boyd, E.

I974 Popular Arts of Spanish New Mexico. Museum of New Mexico Press, Santa Fe.

Bradfield, Maitland

I97 I The Changing Pattern of Hopi Agriculture. Royal Anthropological Institute of Great Britain and Ireland, London.

Brand, Donald

I943 The Chihuahua culture. New Mexico Archaeologist 5-6:3.

Braniff, Beatriz

I988 Observations on the elites of the Pimeria and Opateria in prehispanic times. Paper presented at the Southwest Symposium, Arizona State University, Tempe, January 1 5--I6, 1988.

Braun, David P.

I986 Midwestern Hopewellian exchange and supralocal interaction. In Peer Polity Interaction and Sociopolitical Change, edited by C. Renfrew and J. Cherry, I I7-I 26. Cambridge University Press, Cambridge.

Braun, David P., and Stephen Plog

I 982 Evolution of "tribal" social networks: Theory and prehistoric North American evidence. American Antiquity 47:504-525. 
Breitburg, Emanuel

I 988 Prehistoric New World Turkey Domestication: Origins, Developments, and Consequences. Ph.D. diss., Department of Anthropol-

Briggs, Jerome R. ogy, Southern Illinois University, Carbondale.

1968 A Steppe-Oasis Association in Native North America. Ph.D. diss., Faculty of Political Science, Columbia University, New York.

Bronitsky, Gordon

1982 The Southwest and the Plains: Ecology and economics. Plains Anthropologist 27 (95): 67-76.

Brooke, O. G.

I987 Nutritional requirements of low and very low birth weight infants. Annual Review of Nutrition 7:9I-I I 6.

Brooks, Robert L., ed.

I987 The Arthur Site: Settlement and Subsistence Structure at a Washita River Phase Village. Studies in Oklahoma's Past I 5. Oklahoma Archaeolgical Survey, Norman.

Brooks, Vernon Ralph

I 985 Some Jornada clan symbols and a possible shrine. In Views of the Jornada Mogollon, edited by Colleen M. Beck, 68-77. Eastern New Mexico Contributions in Anthropology 12. Eastern New Mexico University, Portales.

Brown, Donald

I973 Structural Change at Picurís Pueblo, New Mexico. Ph.D. diss., Department of Anthropology, University of Arizona, Tucson.

Brugge, David $M$.

I96 I History, huki, and warfare: Some random data on the lower Pima. Kiva $26(4)$ : 6-I6.

I965 Some Plains Indians in the church records of New Mexico. Plains Anthropologist 10 (29): I 81-189.

1985 Navajos in the Catholic Church Records of New Mexico, I694I875. $2 \mathrm{~d}$ ed. Navajo Community College Press, Tsaile, Arizona.

Bugge, David E., and James Schoenwetter

I974 Pollen studies at Chimney Rock mesa. In Archaeological Investigations at Chimney Rock Mesa: 1970-1972. Memoirs of the Colorado Archaeological Society I.

Burns, Barney T.

I983 Simulated Anasazi Storage Behavior Using Crop Yields Reconstructed from Tree Rings: A.D. 652-I968. Ph.D. diss., Department of Anthropology, University of Arizona, Tucson.

Cahill, George F., Jr.

I986 The future of carbohydrates in human nutrition. Nutrition Reviews $44(2)$ : $40-43$.

Calnek, Edward S.

I982 Patterns of empire formation in the Valley of Mexico, late Postclassic Period, I200-I52I. In The Inca and Aztec States, I400I800: Anthropology and History, edited by George A. Collier, 
Renato I. Rosaldo, and John D. Wirth, 43-62. Academic Press, New York.

Campbell, R. G.

I976 The Panhandle Aspect of the Chaquaqua Plateau. Texas Tech University, Lubbock, Tex.

Campbell, Thomas Jefferson, III

I983 The Greenbelt Site: An Example of Variation Among Prehistoric Plains Village Sites in the Texas Panhandle. M.A. thesis, Department of Anthropology, Texas Tech University, Lubbock.

Caperton, Thomas J.

I98I An archaeological reconnaissance of the Gran Quivira area. In Contributions to Gran Quivira Archaeology, edited by Alden Hayes, 3-I 2. Publications in Archaeology 17. National Park Service, Washington, D.C.

Carlson, G. G., and V. H. Jones

I940 Some notes on uses of plants by the Comanche Indians. Papers of the Michigan Academy of Science, Arts, and Letters 25:517542.

Carlson, Roy L.

I982 The polychrome complexes. In Southwestern Ceramics: A Comparative Review, edited by Albert H. Schroeder, 20 I-234. Arizona Archaeologist I 5 .

Carroll, H. Bailey, and J. Villasona Haggard, eds.

1942 Three New Mexico Chronicles: The Exposición of Don Pedro Bautista Pino, I8I2; the Ojeada of Lic. Antonio Barreiro, I832; and the Additions by Don José Agustín de Escudero, I849. Quivira Society, Albuquerque.

Carter, George F.

I945 Plant Geography and Culture History in the American Southwest. Viking Fund Publications in Anthropology 5. New York.

Carter, R. G.

I969 On the Border with Mackenzie; or, Winning West Texas from the Comanches. Antiquarian Press, New York.

Castetter, Edward F, and Willis H. Bell

I937 Ethnobiological Studies in the American Southwest, IV: The Aboriginal Utilization of the Tall Cacti in the American Southwest. University of New Mexico Bulletin 307, Biological Series 5 (I): I-48.

I95 I Yuman Indian Agriculture. University of New Mexico Press, Albuquerque.

Catlin, George

I973 Letters and Notes on the Manners, Customs, and Conditions of the North American Indians. Dover, New York.

Chisholm, Brian, Jonathan Driver, Sylvain Dube, and Henry P. Schwarcz I 986 Assessment of prehistoric bison foraging and movement patterns via stable-carbon isotopic analysis. Plains Anthropologist $3 \mathrm{I}$ (I I 3): 193-205. 
Collins, Michael B.

I97 I A review of Llano Estacado archaeology and ethnohistory. Plains Anthropologist 16:85-I04.

Colson, Elizabeth

I979 In good years and in bad: Food strategies of self-reliant societies. Journal of Anthropological Research 35 (I): I 8-29.

Cordell, Linda S.

I977 Late Anasazi farming and hunting strategies: One example of a problem of congruence. American Antiquity 42:449-46r.

I979a Cultural Resources Overview: Middle Rio Grande Valley, New Mexico. U.S. Department of Agriculture, Forest Service and Bureau of Land Management. Government Printing Office, Washington, D.C.

1979b Prehistory: Eastern Anasazi. In Handbook of North American Indians, vol. 9: Southwest, edited by Alfonso Ortiz, I3 I-I 5 I. Smithsonian Institution, Washington, D.C.

I980 Tijeras Canyon: Analyses of the Past. University of New Mexico Press, Albuquerque.

I 984 Prehistory of the Southwest. Academic Press, New York.

I 989 Northern and central Rio Grande. In Dynamics of Southwest Prehistory, edited by Linda S. Cordell and George J. Gumerman, 293-335. Smithsonian Institution Press, Washington, D.C.

Cordell, Linda, and Fred Plog

I979 Escaping the confines of normative thought: A reevaluation of Puebloan prehistory. American Antiquity 44:405-429.

Couzzourt, Jim, and Beverly Schmidt-Couzzourt

I988 Report on the 1969 Texas Archaeological Field School at Blue Creek, Moore County, Texas (draft). Panhandle Archaeological Services, Canyon, Tex.

Cozzens, S. W.

I 967 The Marvelous Country. Ross-Haines, Inc., Minneapolis.

Crabb, Martha

I968 Some Puebloan trade pottery from Panhandle Aspect sites. Bulletin of the Texas Archaeological Society 38:83-89.

Creel, Darrell G.

I986 A Study of Prehistoric Burned Rock Middens in West Central Texas. Ph.D. diss., Department of Anthropology, University of Arizona, Tucson.

Cronin, James G.

I969 Ground Water in the Ogallala Formation in the Southern High Plains of Texas and New Mexico. U.S. Geological Survey Hydrological Atlas 330. Government Printing Office, Washington, D.C.

Crouch, Dora P., Daniel J. Garr, and Axel I. Mundigo

I 982 Spanish City Planning in North America. MIT Press, Cambridge, Mass.

Curtis, Edward S.

1930 The North American Indian. Vol. 19. Plimpton, Norwood, Mass. 
Cushing, Frank Hamilton

I920 Zuni Breadstuff. Museum of the American Indian, Indian Notes and Monographs vol. 8. Heye Foundation, New York.

Cutler, Hugh C., and Winton Meyer

I 965 Corn and cucurbits from Wetherill. Memoirs of the Society for American Archaeology I9: I 36-I 52.

Dallman, John E.

I983 A Choice of Diet: Response to Climatic Change. Report I6. University of Iowa, Office of the State Archaeologist, Iowa City.

Dalziel, I. M.

I948 Useful Plants of West Tropical Africa. The Crown Agent for the Colonies, London.

Dean, Glenna

I 986 The Archeobotany of Landergin Mesa. Report on file at the Texas Historical Commission, Austin.

Dean, J. S., R. C. Euler, G. J. Gumerman, F. Plog, R. H. Hevley, and

T.N.V. Karlstrom

I 985 Human behavior, demography, and paleoenvironment on the Colorado Plateaus. American Antiquity 50:537-554.

DeMarcay, Gary

I 986 Vertebrate Fauna from Landergin Mesa: An Antelope Creek Period Village Site. M.A. thesis, Texas A\&M University, College Station.

Dickemann, Mildred

I979 The ecology of mating systems in hypergynous dowry societies. Social Science Information (Sage, London and Beverly Hills) I 8 (2): I63-I 95 .

Dickens, G., and W. H. Trethowan

I97 I Cravings and aversions during pregnancy. Journal of Psychosomatic Research I 5:259-268.

Dickson, J. Bruce, Jr.

I975 Settlement pattern stability and change in the middle Rio Grande region, New Mexico: A test of some hypotheses. American Antiquity 40:I 59-I7I.

1979 Prehistoric Pueblo Settlement Patterns: The Arroyo Hondo, New Mexico, Survey. Arroyo Hondo Archaeological Series 2. School of American Research Press, Santa Fe.

Dillehay, Tom D.

I 974 Late Quaternary bison population changes on the southern Plains. Plains Anthropologist 19 (65): I80-196.

Di Peso, Charles C.

I974 Casas Grandes: A Fallen Trading Center of the Gran Chichimeca. Vols. I-3. Amerind Foundation 9. Dragoon, Ariz.

Di Peso, Charles C., John B. Rinaldo, and Gloria Fenner

I974 Casas Grandes: A Fallen Trading Center of the Gran Chichimeca. Vols. 4-8. Amerind Foundation 9. Dragoon, Ariz.

Dodge, Richard I.

I959 Our Wild Indians: Thirty-Three Years' Personal Experience Among 
the Red Men of the Great West. Reprint of 1882 edition. Archer House, New York.

Douglass, Amy A.

I 988 Prehistoric Exchange and Sociopolitical Development: The Little Colorado Whiteware Production-Distribution System. Ph.D. diss., Department of Anthropology, Arizona State University, Tempe.

Dozier, Edward P.

I96 I Rio Grande Pueblos. In Perspectives in American Indian Culture Change, edited by E. H. Spicer, 94-I 86 . University of Chicago Press, Chicago.

I970 The Pueblo Indians of North America. Holt, Rinehart and Winston, New York.

Drass, Richard R., Timothy G. Baugh, and Peggy Flynn

I987 The Heerwald site and Early Plains Village adaptations in the southern Plains. North American Archaeologist 8 (2): 15 1-190.

Drass, Richard R., and Peggy Flynn

I990 Temporal and geographic variations in subsistence practices for Plains Villagers in the Southern Plains. Plains Anthropologist 35 (128): 175-r9o.

Drass, Richard R., and Michael C. Moore

I987 The Linville II site (34RM492) and Plains Village manifestations in the mixed grass prairie. Plains Anthropologist 32 (I I 8): 404$4 \mathrm{I} 8$.

Drass, Richard R., and Fern E. Swenson

I 986 Variation in the Washita River phase of central and western Oklahoma. Plains Anthropologist 3 I ( I I I ): 35-49.

Duffield, Lathel $\mathrm{F}$.

I970 Some Panhandle Aspect Sites in Texas: Their Vertebrates and Paleoecology. Ph.D. diss., Department of Anthropology, University of Wisconsin, Madison.

Dufour, Darna L.

I985 Manioc as a dietary staple: Implications for the budgeting of time and energy in the northwest Amazon. In Food Energy in Tropical Ecosystems, edited by Dorothy J. Cattle and Karl H. Schwerin, I-2O. Food and Nutrition in History and Anthropology 4. Gordon and Breach, New York.

Dugdale, A. E., and P. R. Payne

r987 A model of seasonal changes in energy balance. Ecology of Food and Nutrition I9 (3): 231-245.

Dumas, William, and Clara Dumas

n.d. Excuvation $[\mathrm{sic}]$ of A-62 or Roper Nr. I. Manuscript on file at the Panhandle-Plains Historical Society, Canyon, Tex.

Dutton, Bertha P.

I 963 Sun Father's Way. University of New Mexico Press, Albuquerque.

Earls, Amy

1987 An Archaeological Assessment of "Las Huertas," Socorro, New 
Mexico. Papers of the Maxwell Museum of Anthropology 3. Albuquerque.

East, W. Gordon

I965 The Geography Behind History. Rev. ed. W. W. Norton, New York.

Ebeling, Walter

I 986 Handbook of Indian Foods and Fibers of Arid America. Univer-

Eddy, Frank W. sity of California Press, Berkeley.

I974 Archaeological Investigations at Chimney Rock Mesa, I9701972. Memoirs of the Colorado Archaeological Society I.

Eder, James

1987 On the Road to Tribal Extinction: Depopulation, Deculturation, and Maladaptation Among the Batak of the Philippines. Univer-

Eighmy, Jeffrey L. sity of California Press, Berkeley.

I984 Colorado Plains Prehistoric Context. Office of Archaeology and Historic Preservation, Colorado Historical Society, Denver.

Ellis, Florence Hawley

I98 I Comments on four papers pertaining to the protohistoric Southwest. In The Protohistoric Period in the North American Southwest, A.D. I450-1700, edited by D. Wilcox and B. Masse, 410433. Arizona State University, Anthropological Research Papers

Evans, Glen L. 24. Tempe.

I949 Upper Cenozoic of the High Plains. In Cenozoic Geology of the Llano Estacado and Rio Grande Valley, I-10. Guidebook, Field Trip No. 2. West Texas Geological Society and New Mexico Geological Society.

Evans, Glen L., and John P. Brand

1956 Eastern Llano Estacado and Adjoining Osage Plain. Guidebook, I 956 Spring Field Trip. West Texas Geological Society and Lubbock Geological Society.

Ewers, J. C.

I955 The Horse in Blackfoot Indian Culture. Bureau of American

Eyerly, T. L. Ethnology Bulletin I 59. Washington, D.C.

I907 The Buried City of the Panhandle. Transactions of the Kansas Academy of Science 2 I (I): 2 I9-228.

Fawcett, William B., Ir.

I987 Communal Hunts, Human Aggregations, Social Variation, and Climatic Change: Bison Utilization by Prehistoric Inhabitants of the Great Plains. Ph.D. diss., Department of Anthropology, University of Massachusetts, Amherst.

Ferring, C. Reid

I986 Late Holocene cultural ecology in the southern Plains: Perspectives from Delaware Canyon, Oklahoma. Plains Anthropologist 3 I (I I4, pt. 2): 55-82. 
Flannery, Kent V.

I968 Archaeological systems theory and early Mesoamerica. In Anthropological Archaeology in the Americas, edited by B. J. Meggers, 67-87. Anthropological Society of Washington, Washington, D.C.

Fletcher, A. C., and F. LaFlesche

I 972 The Omaha Tribe. Vol. I. University of Nebraska Press, Lincoln. Flynn, Peggy

I984 An analysis of the I973 test excavations at the Zimms site (34RM72). In Archaeology of the Mixed Grass Prairie, Phase I: Quartermaster Creek, edited by Timothy Baugh, 215-290. Archaeological Resource Survey Report 20. Oklahoma Archaeological Survey, Norman.

I986 Analysis of test excavations at the Zimms site $\left(34 \mathrm{RM}_{72}\right)$. Plains Anthropologist 3 I (I I 4, pt. 2): 1 29-I40.

Forbes, Jack D.

I960 Apache, Navajo, and Spaniard. University of Oklahoma Press, Norman.

Ford, Richard I.

I968 An Ecological Analysis Involving the Population of San Juan Pueblo, New Mexico. Ph.D. diss., Department of Anthropology, University of Michigan, Ann Arbor.

I972a Barter, gift, or violence: An analysis of Tewa intertribal exchange. In Social Exchange and Interaction, edited by Edwin N. Wilmsen, 2I-45. University of Michigan Museum of Anthropology, Anthropological Paper 46. Ann Arbor.

1972b An ecological perspective on the eastern Pueblos. In New Perspectives on the Pueblos, edited by A. Ortiz, I-I7. University of New Mexico Press, Albuquerque.

1974 Northeastern archaeology: Past and future directions. Annual Review of Anthropology 3:385-4I 3.

1977 The technology of irrigation in a New Mexico pueblo. In Material Culture, edited by Heather Lechtman and Robert Merrill, I 39I 54. Proceedings of the American Ethnological Society, 1975. University of Washington Press, Seattle.

I98 I Gardening and farming before A.D. I000: Patterns of prehistoric cultivation north of Mexico. Journal of Ethnobiology I (I): 6-27.

I983 Inter-Indian exchange in the Southwest. In Handbook of North American Indians, vol. Io: Southwest, edited by Alfonso Ortiz, 7 I I-722. Smithsonian Institution, Washington, D.C.

Ford, Richard I., Albert H. Schroeder, and Stewart L. Peckham

I972 Three perspectives on Puebloan prehistory. In New Perspectives on the Pueblos, edited by Alfonso Ortiz, 22-40. University of New Mexico Press, Albuquerque.

Forde, C. Daryll

I963 The Hopi and Yuma: Flood farmers in the North American desert. 
In Habitat, Economy and Society, 220-259. American Museum of Natural History Press, New York.

Foster, Brian

I977 Trade, social conflict, and social integration: Rethinking some old ideas on exchange. In Economic Exchange and Social Interaction in Southeast Asia, edited by Karl L. Hutterer, 3-22. Michigan Papers on South and Southeast Asia I3. University of Michigan Center for South and Southeast Asian Studies, Ann Arbor.

Fried, $M$.

I 968 The Evolution of Political Society. Random House, New York.

Frye, J. C., and A. B. Leonard

I957 Studies of the Cenozoic Geology Along the Eastern Margin of the Texas High Plains: Armstrong to Howard Counties. Report of Investigations No. 32. Bureau of Economic Geology, University of Texas, Austin.

Gallegos, Lumero Hernán

I927 The Gallegos Relation of the Rodriguez Expedition to New Mexico. Translated and edited by George P. Hammond and Agapito Rey. El Palacio Press, Santa Fe.

Galvin, John, ed.

I970 Through the Country of the Comanche Indians in the Fall of the Year 1845: The Journal of a U.S. Army Expedition Led by Lt. James W. Abert of the Topographical Engineers. John Howell, San Francisco.

Gerald, Rex E.

I973 The Suma Indians of northern Chihuahua and western Texas. In The Changing Ways of Southwestern Indians: A Historic Perspective, edited by Albert H. Schroeder, I-34. Rio Grande Press, Glorieta, New Mexico.

Gibson, D. Blair, and Michael N. Geselowitz

I988 The evolution of complex society in late prehistoric Europe: Toward a paradigm. In Tribe and Polity in Late Prehistoric Europe, edited by D. B. Gibson and M. N. Geselowitz, 3-37. Plenum Press, New York.

Gifford, W. W.

I940 Culture Element Distributions: XII, Apache-Pueblo. Anthropological Records 4, no. I. University of California Press, Berkeley

Gillespie, William B.

I985 Holocene climate and environment of Chaco Canyon. In Environment and Subsistence of Chaco Canyon, New Mexico, edited by F. J. Mathien, I3-45. Publications in Archaeology I8E, Chaco Canyon Studies. U.S. Department of the Interior, National Park Service, Albuquerque.

Goh, B. S.

I979 Stability in models of mutualism. American Naturalist I I 3:26I275 . 
Goodwin, Grenville

I935 The social divisions and economic life of the Western Apache.

Granet, Marcel American Anthropologist 37:55-64.

I958 Chinese Civilization. Meridian Books, New York.

Graves, Michael W.

1982 Breaking down ceramic variation: Testing models of White Mountain Redware design style development. Journal of Field Archaeology I:305-354.

I987 Rending reality in archaeological analysis: A reply to Upham and Plog. Journal of Field Archaeology I 4 (2): 243-249.

Graves, Michael W., and J. Jefferson Reid

I983 Social complexity in the American Southwest: A view from east central Arizona. In Recent Research in Mogollon Archaeology, edited by Steadman Upham, Fred Plog, David Batcho, and Barbara Kauffman, 266-275. University Museum, New Mexico State University, Las Cruces.

Green, F. E.

I986 Report on Archaeological Salvage in the Sanford Reservoir Area. Panhandle Archaeological Society, Publication 4. Amarillo, Tex.

Gregg, Josiah

I954 Commerce of the Prairies. Max Moorhead, ed. I 844. Reprint. University of Oklahoma Press, Norman.

Grinnell, G. B.

1972 The Cheyenne Indians. Vol. I. University of Nebraska Press, Lincoln.

Guffee, E. J.

I976 The Merrell-Taylor Village Site: An Archaeological Investigation of Pre-Anglo, Spanish-Mexican Occupation on Quitaque Creek in Floyd County, Texas. Archeological Research Laboratory, Llano Estacado Museum, Wayland Baptist College, Plainview, Tex.

Guidry, Marion A., Derl L. Brooks, Larry C. Higgins, Jack T. Hughes,

Flavius Killebrew, Gerald E. Schultz, and Robert A. Wright

I 979 An Environmental Profile of the Palo Duro Creek Basin. Submitted to the U.S. Department of the Army, Corps of Engineers, Tulsa District. Killgore Research Center, Faculty of Biology and Geoscience, West Texas State University, Canyon, Tex.

Gunnerson, Dolores

I956 The southern Athabascans: Their arrival in the Southwest. E1 Palacio 63:346-365.

Gunnerson, James

I959 Archaeological survey in northeastern New Mexico. El Palacio 66: I-Io.

I960 An Introduction to Plains Apache Archaeology: The Dismal River Aspect. Bureau of American Ethnology, Anthropological Paper 58. Washington, D.C. 
I968 Plains Apache archaeology: A review. Plains Anthropologist I 3: I 67-1 89.

I969 Apache archaeology in northeastern New Mexico. American Antiquity 34:25-39.

Gunnerson, James, and Dolores Gunnerson

I970 Evidence of Apaches at Pecos. El Palacio 76: I-6.

Guthrie, Helen A.

I975 Introductory Nutrition. 3 d ed. C. V. Mosby, St. Louis.

Habicht Mauche, Judith A.

I988 An Analysis of Southwestern-Style Utility Ware Ceramics from the Southern Plains in the Context of Protohistoric Plains-Pueblo Interaction. Ph.D. diss., Department of Anthropology, Harvard University, Cambridge, Mass.

Habicht-Mauche, Judith A.

I 987 Southwestern-style culinary ceramics on the southern Plains: A case study of technological innovation and cross-cultural interaction. Plains Anthropologist 32 (I I 6): I75-I91.

Habicht-Mauche, Judith A., Alytia A. Levendosky, and Margaret J.

Schoeninger

I 988 Testing Models of Antelope Creek Phase Subsistence Using Bone Chemistry Analysis. Paper presented at the 46th Plains Anthropological Conference, Wichita, Kansas.

Hack, John T.

I942 The Changing Physical Environment of the Hopi Indians of Arizona. Papers of the Peabody Museum 35. Cambridge, Mass.

Hackett, Charles W., ed.

1937 Historical Documents Relating to New Mexico, Nueva Vizcaya, and Approaches Thereto, to 1773. Vol. 3. Carnegie Institution, Washington, D.C.

Hage, Per, and Frank Harary

I983 Structural Models in Anthropology. Cambridge University Press, Cambridge.

Haley, J. Evetts

1935 The comanchero trade. Southwestern Historical Quarterly 38 (3): I $56-176$.

I953 The XIT Ranch in Texas. University of Oklahoma Press, Norman. Hall, Stephen A.

I982 Late Holocene paleoecology of the southern Plains. Quaternary Research I 7:391-407.

I984 Pollen analysis of the Garnsey bison kill site, southeastern New Mexico. In The Garnsey Spring Campsite: Late Prehistoric Occupation in Southeastern New Mexico, edited by W. J. Parry and I. D. Speth, 85-108. University of Michigan Museum of Anthropology, Technical Report I 5. Ann Arbor.

Hall, Stephen A., and Christopher Lintz

r984 Buried trees, water table fluctuations and 3000 years of changing 
climates in west-central Oklahoma. Quaternary Research 22 (I): I29-I 33 .

Hall, Thomas D.

I986 Incorporation in the world-system: Toward a critique. American Sociological Review 5 1:390-402.

I987a Macro Theories and Processes in Regional Events: The Wider Significance of Social Change in New Mexico. Paper presented at the American Society for Ethnohistory Annual Meeting, November I987, Berkeley, California.

1987b Native Americans and incorporation: Patterns and problems. American Indian Culture and Research Journal I I (2): I-30.

I988 Social Change in the Southwest, I350-1880. University Press of Kansas, Lawrence.

Halperin, Charles J.

I 985 Russia and the Golden Horde. Indiana University Press, Bloomington.

Hames, Raymond B.

I980 Game depletion and hunting zone rotation among the Ye'Kwana and Yanomamo of Amazonas, Venezuela. In Working Papers on South American Indians, vol. 2, edited by R. B. Hames, 3I-66. Bennington College, Bennington, Vt.

Hames, Raymond B., and William T. Vickers

I983 Adaptive Responses of Native Amazonians. Academic Press, New York.

Hammond, George P., and Agapito Rey

I940 Narratives of the Coronado Expedition, I540-1542. Coronado Historical Series, vol. 2. University of New Mexico Press, Albuquerque.

1953 Don Juan de Oñate: Colonizer of New Mexico. Coronado Cuarto Centennial Publications, vols. 5 and 6. University of New Mexico Press, Albuquerque.

I966 The Rediscovery of New Mexico, I 580-1594. University of New Mexico Press, Albuquerque.

Hargrave, Lyndon L.

I970 Mexican Macaws. Anthropological Papers of the University of Arizona 20. Tucson.

Harrison, Billy R.

I984 Prehistoric Trade Pipes in the Texas Panhandle. Manuscript on file at the Panhandle-Plains Historical Society, Canyon, Tex.

Hart, Terese B., and John A. Hart

I986 The ecological basis of hunter-gatherer subsistence in African rain forests: The Mbuti of eastern Zaire. Human Ecology I 4 (I): 29-55.

Hayden, Brian

I981 Subsistence and ecological adaptations of modern hunter/gatherers. In Omnivorous Primates: Gathering and Hunting in Human 
Evolution, edited by Robert S. O. Harding and Geza Teleki, 344Hayden, F. V. 42 I. Columbia University Press, New York.

I877 9th Annual Report of the U.S. Geological and Geographical Survey of the Territories, Embracing Colorado and Parts of the Adjacent Territories. Washington, D.C.

Hayes, Alden C.

I98 I Excavation of Mound 7, Gran Quivira National Monument, New Mexico. Publications in Archaeology i6. National Park Service, Washington, D.C.

Haynes, Guy

I932 A Report on the Excavations of Saddleback Ruins. M.A. thesis, Texas Tech University, Lubbock.

Headland, T. N., and L. A. Reid

I 989 Hunter-gatherers and their neighbors from prehistory to the present. Current Anthropology 30:43-66.

Hegsted, Maren, and Hellen M. Linkswiler

I 98 I Long-term effects of level of protein intake on calcium metabo-

Hibben, Frank lism in young adult women. Journal of Nutrition I I I :244-25 I.

I975 Kiva Art of the Anasazi at Pottery Mound. K.C. Publications, Las Vegas, Nevada.

Hill, W. W.

I982 An Ethnography of Santa Clara Pueblo, New Mexico. Edited by

Hirth, Kenneth

C. H. Lange. University of New Mexico Press, Albuquerque.

I 978 Interregional trade and the formation of prehistoric gateway communities. American Antiquity 43 (I): 35-45.

Hobbs, Hulda R.

I 94 I Texas Panhandle ruins. El Palacio 48 (6): I 2 I-I 28.

Hofman, Jack L.

I978 An analysis of surface materials from the Little Deer site, 34 -CuIO, of western Oklahoma: A further investigation of the Wheeler complex. Bulletin of the Oklahoma Anthropological Society 27:I-IIO.

1984a Hunter-gatherers in the Nashville Basin of Tennessee, $8000-5000$ B.P. Tennessee Anthropologist 9 (2): 129-192.

I984b The western protohistoric: A summary of the Edwards and Wheeler complexes. In Prehistory of Oklahoma, edited by Robert

Holden, Tom E. Bell, 347-362. Academic Press, Orlando, Fla.

I934 A Study of the Pottery of Saddleback Ruin. M.A. thesis, Texas Tech University, Lubbock.

Holden, W. C.

I929 Some explorations and excavations in northwest Texas. Bulletin of the Texas Archaeological and Paleontological Society I:23-35. 
I930 The Canadian Valley expedition of March, I930. Bulletin of the Texas Archaeological and Paleontological Society 2:2 I-32.

I93 I Texas Tech Archaeological Expedition, Summer 1930. Bulletin of the Texas Archaeological and Paleontological Society 3:43-52.

1932 Recent archaeological discoveries in the Texas Panhandle. Southwestern Social Science Quarterly I 3:289-293.

1933 Excavations at Saddleback Ruin. Bulletin of the Texas Archaeolog. ical and Paleontological Society 5:39-52.

Holliday, Vance T., Eileen Johnson, Herbert Haas, and Robert Stuckenrath

I983 Radiocarbon ages from the Lubbock Lake site, I950-I980: Framework for cultural and ecological change on the southern High Plains. Plains Anthropologist 28 (IOI): I65-182.

Honea, Kenneth $\mathrm{H}$.

I973 The technology of eastern Puebloan pottery on the Llano Estacado. Plains Anthropologist I 8 (59): 73-88.

Hood, H. Charles, and James R. Underwood, Jr.

1978 Geology of Palo Duro Canyon. Panhandle-Plains Historical Review 51:3-33.

Hook, E. B.

1978 Dietary cravings and aversions during pregnancy. American Journal of Clinical Nutrition 31: I355-1362.

Howard, James, and Donald Brown

1973 A Puebloid burial from western Oklahoma. Bulletin of the Oklahoma Anthropological Society 22:207-2 I6.

Hughes, David, and Alicia Hughes-Jones

I987 The Courson Archaeological Projects: Final I985 and Preliminary 1986. Courson Archaeological Projects, Perryton, Tex.

Hughes, Jack $T$.

I978 Archeology of Palo Duro Canyon. Panhandle-Plains Historical Review 51:35-58.

1979 Archaeology of Palo Duro Canyon. In The Story of Palo Duro Canyon, edited by Duane Guy, 35-58. Panhandle-Plains Historical Society, Canyon, Tex.

n.d. Cultural Developments During the Archaic and NeoIndian Stages on the Texas High Plains. Ms. on file. Archaeological Research Laboratory, Killgore Research Center, West Texas State University, Canyon, Tex.

Hughes, Jack T., H. Charles Hood, and Billy Pat Newman

I978 Archaeological Testing in the Red Deer Creek Watershed in Gray, Roberts, and Hemphill Counties, Texas. Submitted to the National Park Service. Archaeological Research Laboratory, Killgore Research Center, West Texas State University, Canyon, Texas.

Hughes, Jack T., and Patrick S. Willey

I978 Archeology at Mackenzie Reservoir. Archeological Survey Report 24. Office of the State Archeologist, Texas Historical Commission, Austin. 
Hunter-Anderson, Rosalind L.

I98 I Comments on Cordell and Plog's "Escaping the confines of normative thought." American Antiquity 46 (I): 194-197.

Huscher, Harold A., and Betty $\mathrm{H}$. Huscher

I943 The Hogan Builders of Colorado. Colorado Archaeological Society, Gunnison.

Hutterer, Karl L.

I982 Interaction Between Tropical Ecosystems and Human Foragers: Some General Considerations. East-West Environment and Policy Institute Working Paper. East-West Center, Honolulu, Hawaii.

Jackson, W. H.

I876 A Notice of the Ancient Ruins in Arizona and Utah Lying About the Rio San Juan. Bulletin of the U.S. Geological and Geographical Survey of the Territories, vol. 2, no. I, pt. 2. Washington, D.C.

James, Thomas

I962 Three Years Among the Indians and Mexicans. I 846. Reprint. J. B. Lippincott, Philadelphia.

Janzen, D. H.

I985 The natural history of mutualisms. In The Biology of Mutualism, edited by D. H. Boucher, 40-99. Croom Helm, London.

Jelinek, Arthur J.

I967 A Prehistoric Sequence in the Middle Pecos Valley, New Mexico. University of Michigan Museum of Anthropology, Anthropological Paper 3 I. Ann Arbor.

Jochim, Michael A.

I98 I Strategies for Survival: Cultural Behavior in an Ecological Context. Academic Press, New York.

John, Elizabeth A. H.

1975 Storms Brewed in Other Men's Worlds: The Confrontation of Indians, Spanish and French in the Southwest, I 540-1795. University of Nebraska Press, Lincoln.

I 984 Nurturing the peace: Spanish and Comanche cooperation in the early nineteenth century. New Mexico Historical Review 59 (4): $345-369$.

1987 Documentary evidence and historical context bearing upon possible explanations of a brief, specialized settlement on the eastern Plains of New Mexico. In Investigations at Sites 48 and 77, Santa Rosa Lake, Guadalupe County, New Mexico, edited by Frances Levine and Joseph C. Winter, 539-549. Office of Contract Archaeology, University of New Mexico, Albuquerque.

Johnson, Eileen, Vance T. Holliday, Michael J. Kaczor, and

Robert Stuckenrath

1977 The Garza occupation at the Lubbock Lake site. Bulletin of the Texas Archaeological Society 48:83-ro9.

Johnson, Gregory

1977 Aspects of regional analysis in archaeology. Annual Review of Anthropology 6:479-508. 
Jones, Kevin T.

I984 Hunting and Scavenging by Early Hominids: A Study in Archeological Method and Theory. Ph.D. diss., Department of Anthropology, University of Utah, Salt Lake City.

Jones, Volney

I936 The vegetal remains of Newt Kash Hollow Shelter. In Rockshelters in Menifee County, Kentucky, edited by W. S. Webb and W. D. Funkhouser, 147-165. University of Kentucky Reports in Anthropology and Archaeology 3, pt. 4.

Jorgensen, J. C.

I983 Comparative traditional economics and ecological adaptations. In Handbook of North American Indians, vol. Io: Southwest, edited by Alfonso Ortiz, 684-7 I0. Smithsonian Institution, Washington, D.C.

Katz, Paul R., and Susana R. Katz

I976 Archeological Investigations in Lower Tule Canyon, Briscoe County, Texas. Archeological Survey Report No. I6. Texas Historical Foundation, Texas Tech University, Texas Historical Commission, Office of the State Archeologist.

Katzenberg, M. A., and J. H. Kelley

n.d. Stable isotope analysis of prehistoric bone from the Sierra Blanca region of New Mexico. Manuscript on file at the Department of Archaeology, University of Calgary, Calgary.

Kavanaugh, Thomas $W$.

I986 Political Power and Political Organization: Comanche Politics, I 786-I 875. Ph.D. diss., Department of Anthropology, University

Keeler, K. of New Mexico, Albuquerque.

I98 I A model of selection for facultative nonsymbiotic mutualism. American Naturalist i I 8:488-498.

Keller, John Esten

I975 The Black Dog Village site: A Panhandle Aspect manifestation in Hutchinson County, Texas. Texas Highway Department, Publications in Archaeology, Report 5. Austin.

Kelley, J. Charles

I952 Factors involved in the abandonment of certain peripheral southwestern settlements. American Anthropologist 54:356-387.

I955 Juan Sabeata and diffusion in aboriginal Texas. American Anthropologist 57:98 I-995.

I986 Jumano and Patarabueye Relations at La Junta de los Rios. University of Michigan Museum of Anthropology, Anthropological Paper 77. Ann Arbor.

Kelley, J. Charles, and Ellen Abbott Kelley

I975 An alternative hypothesis for the explanation of Anasazi culture history. In Collected Papers in Honor of Florence Hawley Ellis, edited by Theodore R. Frisbie, 178-223. Papers of the Archaeological Society of New Mexico 2. Albuquerque. 
Kelley, Jane Holden

1984 The Archaeology of the Sierra Blanca Region of Southeastern New Mexico. University of Michigan Museum of Anthropology, Anthropological Paper 74. Ann Arbor.

Kelly, Roger E.

I963 The Socio-Religious Roles of Ball Courts and Great Kivas in the Prehistoric Southwest. M.A. thesis, Department of Anthropology, University of Arizona, Tucson.

Kenner, Charles L.

I969 A History of New Mexican-Plains Indian Relations. University of Oklahoma Press, Norman.

Kerr-Grieve, J. F., B. M. Campbell-Brown, and F. D. Johnstone

I979 Dieting in pregnancy: A study of the effect of a high protein low carbohydrate diet on birthweight in an obstetric population. In International Colloquium on Carbohydrate Metabolism in Pregnancy and the Newborn 1978 , edited by H. W. Sutherland and

Kessell, J. J. M. Stowers, 5 I 8-534. Springer-Verlag, New York.

I979 Kiva, Cross, and Crown. National Park Service, Washington, D.C. Kidder, Alfred V.

1932 The Artifacts of Pecos. Phillips Academy Papers of the Southwestern Expedition 6, Andover. Yale University Press, New Haven.

1958 Pecos, New Mexico: Archaeological Notes. Papers of the Robert S. Peabody Foundation for Archaeology 5. Phillips Academy, Andover.

Kidder, Alfred V., and Anna O. Shepard

I936 The Pottery of Pecos. Vol. 2. Phillips Academy Papers of the Southwestern Expedition 7, Andover. Yale University Press, New Haven.

King, Mary Elizabeth, and Joan S. Gardner

I98I The analysis of textiles from Spiro Mound, Oklahoma. In The Research Potential of Anthropological Museum Collections, edited by Anne-Marie E. Cantwell, James B. Griffin, and Nan A. Rothschild, 123-I 39. Annals of the New York Academy of Science 376.

Kingsolver, J. M., C. D. Johnson, S. R. Swier, and A. Teran

I 977 Prosopis fruits as a resource for invertebrates. In Mesquite: Its Biology in Two Desert Scrub Ecosystems, edited by B. B. Simpson, I08-I 22. US/IBP Synthesis Series 4. Dowden, Hutchinson and

Kintigh, Keith W. Ross, Stroudsburg, Pennsylvania.

I985 Settlement, Subsistence, and Society in Late Zuni Prehistory. Anthropological Papers of the University of Arizona 44. Tucson.

Kirkby, Ann

I973 The Use of Land and Water Resources in the Past and Present Valley of Oaxaca, Mexico. University of Michigan Museum of Anthropology Memoir 5. Ann Arbor. 
Kohl, Philip L.

I987 The use and abuse of world systems theory: The case of the pristine West Asian state. In Advances in Archaeological Method and Theory II, edited by Michael Schiffer, I-35. Academic Press, New York.

Krieger, Alex D.

I946 Culture Complexes and Chronology in Northern Texas. University of Texas Publication 4640. Austin.

Lambert, Mariorie F.

1954 Paa-ko: Archaeological Chronicle of an Indian Village in North Central New Mexico. Monograph No. 19, pts. I-5. School of American Research, Santa Fe.

Lange, Charles

I957 Plains-southwestern inter-cultural relations during the historic period. Ethnohistory 4 (2): I 50-173.

I959 Cochiti: A New Mexico Pueblo, Past and Present. Southern Illinois University Press, Carbondale.

Leacock, Eleanor, and Richard Lee, eds.

I982 Politics and History in Band Societies. Cambridge University Press, Cambridge.

LeBlanc, Steven A.

I980 The dating of Casas Grandes. American Antiquity 45:799-806.

I983 The Mimbres People. Thames and Hudson, London.

I986 Aspects of southwestern prehistory, A.D. 900-I 400. In Ripples in the Chichimec Sea, edited by Frances Joan Mathien and Randall H. McGuire, I05-I34. Southern Illinois University Press, Carbondale.

Lechtig, A., et al.

I978 Effect of maternal nutrition on infant mortality. In Nutrition and Human Reproduction, edited by W. H. Mosley, I47-174. Plenum, New York.

Lees, William B.

I987 Highway archaeology salvage program investigates Great Bend Aspect site. Kansas Preservation 9 (3): 6-8.

I989 Final Summary Report: I986 Archeological Investigations at I4MN328, A Great Bend Aspect Site Along U.S. Highway 56, Marion County, Kansas. Manuscript on file at the Kansas Department of Transportation and the Kansas State Historical Society, Topeka.

I990 Evidence for Early European Contact with the Wichita in Kansas. Paper presented to the Twenty-third Annual Meeting of the Soci-

Lehmer, Donald J. ety for Historical Archaeology, Tucson.

I948 The Jornada Branch of the Mogollon. University of Arizona Social Science Bulletin I7. Tucson.

I954 Archaeological Investigations in the Oahe Dam Area, South Dakota, I950-5I. Bureau of American Ethnology, Bulletin I 58 , 
River Basin Survey Paper 7. Government Printing Office, Washington, D.C.

I97 I Introduction to Middle Missouri Archeology. Anthropology Paper I. U.S. Department of the Interior, National Park Service, Washington, D.C.

Lekson, Steven $\mathbf{H}$.

I984 Dating Casas Grandes. Kiva 5o (I): 55-60.

I985 Largest settlement size and the interpretation of socio-political complexity at Chaco Canyon, New Mexico. Haliksa'i: UNM Contributions to Anthropology 4:68-75.

Levendosky, Alytia A.

I 987 A Dietary Analysis of Antelope Creek Phase Using Bone Chemistry Analyses to Test Dietary Models Based on Archaeological Evidence and Environmental Reconstruction. B.A. honors thesis, Harvard University, Cambridge, Mass.

Levine, Frances

I983 A Brief Overview of the Comanchero Trade. Manuscript on file, Albuquerque Museum of Art and Science, Albuquerque.

I984 Ethnohistoric clues to the identification of historic Plains Indian sites. New Mexico Archaeological Council, Conference on the Archaeology of Northeastern New Mexico. New Mexico Archaeological Council Proceedings 6 ( $\mathrm{x}$ ): 29-42.

Levine, Frances, and Martha Doty Freeman

I982 A Study of Documentary and Archeological Evidence for Comanchero Activity in the Texas Panhandle. Manuscript on file, Texas Historical Commission, Austin.

Levine, Frances, and Joseph C. Winter

I987 Investigations at Sites 48 and 77. Santa Rosa Lake, Guadalupe County, New Mexico. Office of Contract Archeology, University of New Mexico, Albuquerque.

Lightfoot, Kent G.

I987 A consideration of complex prehistoric societies in the U.S. Southwest. In Chiefdoms in the Americas, edited by Robert D. Drennan and Carlos A. Uribe, 43-58. University Press of America, Lanham, Maryland.

Linares, Olga F.

I976 "Garden hunting" in the American tropics. Human Ecology 4 (4): 33 I -349.

Lintz, Christopher R.

1976 The McGrath site of the Panhandle Aspect. Bulletin of the Oklahoma Anthropological Society 25:I-I 10.

1986a Architecture and Community Variability Within the Antelope Creek Phase of the Texas Panhandle. Studies in Oklahoma's Past I 4. Oklahoma Archaeological Survey, Norman.

1986b The historical development of a culture complex: The basis for understanding architectural misconceptions of the Antelope Creek Focus. Plains Anthropologist 3 I ( I I 4): I I I-1 28. 
I990 Landergin Mesa: I984 Phase II Field Results (draft). Manuscript on file at the Texas Archaeological Research Laboratory, University of Texas, Austin.

Lintz, Christopher, and Stephen A. Hall

1983 The Geomorphology and Archaeology of Carnegie Canyon, Fort Cobb Laterals Watershed, Caddo County, Oklahoma. Oklahoma Conservation Commission, Archaeological Research Report Io. Oklahoma City.

Lowrey, E. J.

I932 The Archaeology of the Antelope Creek Ruin. M.A. thesis, Texas Tech University, Lubbock.

Luckey, Richard R., Edwin D. Gutentag, and John B. Weeks

I98I Water-level and Saturation-thickness Changes, Predevelopment to 1980 , in the High Plains Aquifer in Parts of Colorado, Kansas, Nebraska, New Mexico, Oklahoma, South Dakota, Texas and Wyoming. U.S. Geological Survey, Hydrological Atlas 652, Government Printing Office, Washington, D.C.

Lumbach, Karl, and David Kirkpatrick

I985 The Black Range project: A regional perspective. In Proceedings of the Third Jornada Mogollon Conference, edited by Michael S. Foster and Thomas C. O'Laughlin, 23-40. The Artifact $23(\mathrm{I}-2)$.

Lynott, Mark J.

I980 Prehistoric bison populations of northcentral Texas. Bulletin of the Texas Archaeological Society 50:89-Ior.

McArdle, William D., Frank I. Katch, and Victor L. Katch

I986 Exercise Physiology: Energy, Nutrition, and Human Performance. Lea and Febiger, Philadelphia.

McGilvery, Robert W.

I 983 Biochemistry: A Functional Approach. 3d ed. W. B. Saunders Company, Philadelphia.

McGuire, Randall $\mathrm{H}$.

I 980 The Mesoamerican connection in the Southwest. Kiva $46(1-2)$ : $3-38$.

McWilliams, K. Richard, and Jerry Johnson

I979 Physical evidence on the origin of the Panhandle Aspect. Plains Anthropologist 24 (85): 249-253.

Marcy, R. B.

I866 Thirty Years of Army Life on the Border. Harper and Brothers, New York.

Marmaduke, William S.

r975 Reconnaissance and archaeological studies in the Canadian River Valley. In Canadian Breaks: A Natural Area Survey, Part VI of VII, 68-95. Texas Parks and Wildlife Department, Division of Natural Resources and Environment. University of Texas, Austin.

Marshall, Michael P.

I973 The Jornada culture area. In Technical Manual: 1973 Survey of 
the Tularosa Basin, The Research Design, 49-I20. Human Systems Research, New Mexico.

I987 Qualacu: Archaeological Investigation of a Piro Pueblo. U.S. Fish and Wildlife Service and the University of New Mexico Office of Contract Archaeology, Albuquerque.

1989 Archaeological Investigations in the Rio Medio District of the Rio Grande Valley, New Mexico. Historic Preservation Division, Santa Fe.

Marshall, Michael P., and Henry J. Walt

I 984 Rio Abajo: Prehistory and History of a Rio Grande Province. Historic Preservation Division, New Mexico Historic Preservation Program, Santa Fe.

Martin, Paul S., and F. W. Sharrock

I964 Pollen analysis of prehistoric human feces: A new approach to ethnobotany. American Antiquity 30: I 68-i 80 .

Martorell, R., and T. Gonzalez-Cossio

I987 Maternal nutrition and birth weight. Yearbook of Physical Anthropology 30:195-220.

Mathien, Frances Joan, and Randall H. McGuire, eds.

I986 Ripples in the Chichimec Sea. Southern Illinois University Press, Carbondale.

Mayhall, M. P.

I 97 I The Kiowas. 2d ed. University of Oklahoma Press, Norman.

Maynard Smith, J., and G. A. Parker

1976 The logic of asymmetric contests. Animal Behavior 24:159I 75 .

Mead, James F., R. B. Alfin-Slater, D. R. Howton, and G. Popjak

I 986 Lipids: Chemistry, Biochemistry, and Nutrition. Plenum Press, New York.

Medina, Jose Gertrude [sic]

I 893 Deposition of Jose Gertrude Medina, 26 June 1893 . Indian Depredation Case File No. 99133. Records of the U.S. Court of Claims, Record Group 2 I. National Archives, Washington, D.C.

Mera, H. P.

I934 A Survey of the Biscuit Ware Area in Northern New Mexico. Laboratory of Anthropology Technical Series Bulletin 6. Santa Fe.

I935 Ceramic Clues to the Prehistory of North Central New Mexico. Laboratory of Anthropology Technical Series Bulletin 8. Santa Fe.

I940 Population Changes in the Rio Grande Glaze-Paint Area. Laboratory of Anthropology Technical Series Bulletin 9. Santa Fe.

1943 An Outline of Ceramic Development in Southern and Southeastern New Mexico. Laboratory of Anthropology Technical Series Bulletin I I. Santa Fe.

Merritt, C. A.

I958 Igneous Geology of the Lake Altus Area, Oklahoma. Oklahoma Geological Survey, Bulletin No. 76. Norman. 
Meyer, Daniel

I 984 Processing, Utilization and Economics of Mesquite Pods as a Raw Material for the Food Industry. Doctor of Technical Sciences diss., Swiss Federal Institute of Technology, Zurich (Diss. ETH 7688 , published by Juris Druck and Verlag, Zurich).

Miller, Sanford A., and Geraldine V. Mitchell

I982 Optimisation of human protein requirements. In Food Proteins, edited by P. F. Fox and J. J. Condon, 105-120. Applied Science Publishers, London.

Minge, Ward Alan

I979 Efectos del país: A history of weaving along the Rio Grande. In Spanish Textile Traditions of New Mexico and Colorado, 8-28. Museum of New Mexico Press, Santa Fe.

Minnis, Paul E.

I980 Domesticating Plants and People in the Greater Southwest. Paper presented at the School of American Research Advanced Seminar: The Origins of Plant Husbandry in North America, Santa Fe.

I984 Peeking under the tortilla curtain: Regional interaction and integration on the northeastern periphery of Casas Grandes. American Archaeology 4 (3): I 8I-I93.

I985 Social Adaptation to Food Stress: A Prehistoric Southwestern Example. University of Chicago Press, Chicago.

I989 The Casas Grandes polity in the international Four Corners. In The Sociopolitical Structure of Prehistoric Southwestern Societies, edited by Steadman Upham, Kent G. Lightfoot, and Roberta A. Jewett, 269-306. Westview Press, Boulder, Colorado.

Minnis, Paul, and Richard I. Ford

I974 Analysis of plant remains from Chimney Rock mesa. In Archaeological Investigations at Chimney Rock Mesa, 1970-1972. Memoirs of the Colorado Archaeological Society I.

Mitchell, Jimmy, Thomas Hester, Frank Asaro, and Fred Stross

I980 Notes on trace element analysis of obsidian from Hutchinson and Roberts counties in the Texas Panhandle. Bulletin of the Texas Archaeological Society 51:301-308.

Monger, Earl

1970 A preliminary report of the Larned site. Kansas Anthropological Association Newsletter I5 (6): I-I 5 .

Moorehead, Warren $\mathrm{K}$.

I93 I Archaeology of the Arkansas River Valley. Yale University Press, New Haven.

Morris, Brian

I982 Forest Traders: A Socioeconomic Study of the Hill Pandaram. London School of Economics Monograph on Social Anthropology 35. Athlone Press, New Jersey.

National Academy of Sciences

I 985 Preventing Low Birthweight. Committee to Study the Prevention of Low Birthweight, Division of Health Promotion and Disease 
Prevention, Institute of Medicine. National Academy Press, Washington, D.C.

Naylor, Thomas N.

I985 Casas Grandes Outlier Ball Courts in Northwest Chihuahua. In International Symposium on the Mesoamerican Ball Game, assembled by David R. Wilcox and Vernon L. Scarborough, 536-553. Manuscript on file, Arizona State Museum Library, University of Arizona, Tucson.

Ndagala, D. K.

I 988 Free or doomed? Images of the Hadzabe hunters and gatherers of Tanzania. In Hunters and Gatherers, vol. I: History, Evolution and Social Change, edited by T. Ingold, D. Riches, and J. Woodburn, 65-72. Berg, Oxford.

Nelson, Ben A., and Linda S. Cordell

I 982 Dynamics of the Anasazi adaptation. In Anasazi and Navajo Land Use in the McKinley Mine Area near Gallup, New Mexico, vol. I, pt. 2, edited by C. G. Allen and B. A. Nelson, 867-893. Office of Contract Archaeology, University of New Mexico, Albuquerque.

Neusius, Sarah W.

I984 Garden Hunting and Anasazi Game Procurement: Perspectives from Dolores. Paper presented at the 49th Annual Meeting of the Society for American Archaeology, Portland, Oregon, April 1984.

Newcomb, W. W.

I955 An historic burial from Yellowhouse Canyon, Lubbock County. Bulletin of the Texas Archaeological Society 26: 186-199.

1961 The Indians of Texas: From Protohistoric to Modern Times. University of Texas Press, Austin.

I 967 New light on Wichita culture. In A Pilot Study of Wichita Indian Archaeology and Ethnohistory, assembled by R. E. Bell, E. B. Jelks, and W. W. Newcomb, 3IO-33I. Final Report Submitted to the National Science Foundation.

I 976 The People Called Wichita. Indian Tribal Series. Phoenix.

n.d. Wichita. Manuscript in possession of the author.

New Mexico State University

n.d. Blue Corn. Department of Agriculture, Division of Marketing and Development circular o5.19. Las Cruces.

Noli, Dieter, and Graham Avery

I 988 Protein poisoning and coastal subsistence. Journal of Archaeological Science I 5:395-401.

Northern, Martin James

I979 Archaeological Investigations of the Montgomery Site, Floyd County, Texas. M.A. thesis. Texas Tech University, Lubbock.

Oliver, Symmes

1962 Ecology and Cultural Continuity as Contributing Factors in the Social Organization of the Plains Indians. University of California Publications in American Archaeology and Ethnology, vol. 48. Berkeley. 
Orians, Gordon H., and Nolan E. Pearson

I979 On the theory of central place foraging. In Analysis of Ecological Systems, edited by D. J. Horn, G. R. Stairs, and R. D. Mitchell, I 55-I77. Ohio State University Press, Columbus.

Ortiz, Alfonso

I969 The Tewa World. University of Chicago Press, Chicago.

Pailes, Richard A.

I980 The upper Rio Sonoras valley in prehistoric trade. In New Frontiers in the Archaeology and Ethnohistory of the Greater Southwest, edited by Carroll L. Riley and Basil C. Hedrick, 20-39. Transactions of the Illinois State Academy of Science, vol. 72, no. 4.

Parker, G. A., and D. L. Rubenstein

I98 I Role assessment, reserve strategy, and acquisition of information in asymmetric animal conflicts. Animal Behavior 29:22 I-240.

Parker, Wayne

I982 Archeology at the Bridwell Site. Crosby County Pioneer Memorial, Crosbyton, Tex.

Parsons, Elsie Clews

I936 Taos Pueblo. General Series in Anthropology 2. Menasha, Wisconsin.

Parsons, Mark L.

1967 Archeological Investigations in Crosby and Dickens Counties, Texas During the Winter, I966-I967. Report No. 7, pp. I-Io8. Texas State Building Commission Archeological Program, Austin.

Patterson, David A.

I975 An Analysis of Human Skeletal Materials from the Antelope Creek Focus of North Texas. M.A. thesis, Eastern New Mexico University, Portales.

Pennington, Campbell W.

I963 The Tarahumara of Mexico: Their Environment and Material Culture. University of Utah Press, Salt Lake City.

I969 The Tepehuan of Chihuahua: Their Material Culture. University of Utah Press, Salt Lake City.

I980 The Pima Bajo. Vol. 1: The Material Culture. University of Utah Press, Salt Lake City.

Phelps, Alan L.

I974 An analysis of the ceramics of the Guadalupe Mountains National Park. Texas Archaeological Society Bulletin 45: I2 I-1 50.

Phillips, Philip, and James A. Brown

1978 Pre-Columbian Shell Engraving from the Craig Mound at Spiro Oklahoma. Pt. I. Peabody Museum Press, Harvard University, Cambridge, Mass.

Pillaert, Elizabeth

I963 The McLemore site of the Washita River Focus. Bulletin of the Oklahoma Anthropological Society I I: I-I I 4 . 
Piperno, Dolores R.

1989 Non-affluent foragers: Resource availability, seasonal shortages, and the emergence of agriculture in Panamanian tropical forests. In Foraging and Farming: The Evolution of Plant Exploitation, edited by D. R. Harris and G. C. Hillman, 538-554. Unwin Plog, Fred Hyman, London.

I979 The Keresan bridge: An ecological and archaeological account. In Social Archaeology, edited by Charles Redman et al., 349-372. Academic Press, New York.

I984 Exchange, tribes and alliances: The northern Southwest. American Archaeology 4:217-223.

I985 Status and death at Grasshopper Pueblo: The homogenization of reality. In Status, Structure, and Stratification: Current Archaeological Reconstruction; Proceedings of the I6th Chacmool Conference, edited by Marc Thompson, Maria Teresa Garcia, and Francois J. Kense, I6I-I65. University of Calgary, Calgary.

Plog, Fred, and Steadman Upham

I 983 The analysis of prehistoric political organization. In The Development of Political Organization in Native North America, edited by Elizabeth Tooker and Morton Fried, I99-213. American Ethnological Society, Washington, D.C.

Profet, $M$.

n.d. Pregnancy sickness as adaptation: A deterrent to maternal ingestion of teratogens. In The Adapted Mind: Evolutionary Psychology and the Generation of Culture, edited by J. Barkow, L. Cosmides, and J. Tooby (in press).

Pulliam, H. Ronald

I98 I On predicting human diets. Journal of Ethnobiology I (I): 6I68.

Quimby, George I., and Alexander Spoehr

I95 I Acculturation and material culture-I. Fieldiana 36 (6): 107-I 47. Chicago Natural History Museum.

Rathjen, Frederick W. I 973 The Texas Panhandle Frontier. University of Texas Press, Austin.

Ravesloot, John C., Jeffrey S. Dean, and Michael S. Foster

I986 A New Perspective on the Casas Grandes Tree-Ring Dates. Paper presented at the Fourth Mogollon Conference, University of Arizona, October I6-I7, I986.

Ray, Cyrus N., and Edward B. Jelks

I 964 The W. H. Watson site: An historic Indian burial in Fisher County, Texas. Bulletin of the Texas Archaeological Society 35:127-141.

Reff, Daniel T.

I987a The introduction of smallpox in the Greater Southwest. American Anthropologist 89 (3): 704-708.

I $987 \mathrm{~b}$ Old World diseases and the dynamics of Indian and Jesuit relations 
Reher, C. A.

in northwestern New Spain, I 520-1660. In Ejidos and Regions of Refuge in Northwestern Mexico, edited by N. Ross Crumrine and Phil C. Weigand, 85-94. Anthropological Papers of the University of Arizona 46. Tucson.

I977 Settlement and Subsistence Along the Lower Chaco River: The CGP Survey. University of New Mexico Press, Albuquerque.

Reher, C. A., and G. C. Frison

I980 The Vore Site, 48CK302: A Stratified Buffalo lump in the Wyoming Black Hills. Plains Anthropologist Memoir I6.

Rice, Prudence $M$.

I 987a Lowland Maya pottery production in the Late Classic period. In Maya Ceramics: Papers from the 1985 Maya Ceramics Conference, edited by Prudence Rice and Robert Sharer, 525-543. BAR International Series 345 (ii). Oxford.

I $987 \mathrm{~b}$ Pottery Analysis: A Sourcebook. University of Chicago Press, Chicago.

Richards, Michael K.

I97I The Lee site: A late prehistoric manifestation in Garvin County, Oklahoma. Bulletin of the Oklahoma Anthropological Society 20: I-82.

Riley, Carroll L.

I978 Pecos and trade. In Across the Chichimec Sea, edited by Carroll L. Riley and Basil C. Hedricks, 53-66. Southern Illinois University Press, Carbondale.

1982 The Frontier People, the Greater Southwest in the Protohistoric Period. Southern Illinois University at Carbondale Center for Archaeological Investigations, Occasional Paper I.

Riley, John A.

I984 Pottery analysis and the reconstruction of ancient exchange systems. In The Many Dimensions of Pottery, edited by S. E. van der Leeuw and A. C. Pritchard, 55-73. Albert Egges Van Giffen Instituut, Universiteit van Amsterdam, Amsterdam.

Rinaldo, John B.

I964 Notes on the origin of historic Zuni culture. Kiva 29 (4): 86-98.

Robbins, Wilfred W., J. P. Harrington, and B. Freire-Marreco

I9I 6 Ethnobotany of the Tewa Indians. Bureau of American Ethnology Bulletin 55. Smithsonian Institution, Washington, D.C.

Robertson, Linda B.

I983 Achiya: Dekyap'bowa: Alliance and Polity in the Development of Cibola. Ph.D. diss., Department of Anthropology, Brown University, Providence, Rhode Island.

Rocek, Thomas R., and John D. Speth

I 986 The Henderson Site Burials: Glimpses of a Late Prehistoric Population in the Pecos Valley. University of Michigan Museum of Anthropology Technical Report 18, Ann Arbor. 
Roe, F. G.

1970 The North American Buffalo. 2d ed. University of Toronto Press, Toronto.

Rohn, Arthur H., and Alice M. Emerson

I984 Great Bend Sites at Marion, Kansas. Wichita State University Publications in Anthropology I.

Rohrbaugh, Charles L.

I984 Arkansas Valley Caddoan: Fort Coffee and Neosho foci. In Prehistory of Oklahoma, edited by Robert E. Bell, 265-286. Academic Press, New York.

Rowlison, Don

I98I K.A.A. dig and Kansas archaeology training program uncovers pithouses near Lyons. Journal of the Kansas Anthropological As-

Runkles, Frank sociation $2(5-6)$ : I I 8 - I 20.

I964 The Garza site: A neo-American campsite near Post, Texas. Bulletin of the Texas Archaeological Society 35:IOI-I 25.

Runkles, Frank, and E. D. Dorchester

I987 The Lott site (4IGR56): A late prehistoric site in Garza County, Rush, David Texas. Bulletin of the Texas Archaeological Society 57:83-I I6.

I982 Effects of changes in protein and calorie intake during pregnancy on the growth of the human fetus. In Effectiveness and Satisfaction in Antenatal Care, edited by M. Enkin and I. Chalmers, 92I I 3. Clinics in Developmental Medicine Nos. 8I/82. J. B. Lippincott, Philadephia.

I986 Nutrition in the preparation for pregnancy. In Pregnancy Care: A Manual for Practice, edited by G. Chamberlain and J. Lumley, I I 3-I 39. Wiley, New York.

1989 Effects of changes in protein and calorie intake during pregnancy on the growth of the human fetus. In Effective Care in Pregnancy and Childbirth, vol. I: Pregnancy, edited by I. Chalmers, M. Enkin, and M.J.N.C. Keirse, 255-280. Oxford University Press, Oxford.

Rush, D., Z. Stein, and M. Susser

I980 A randomized controlled trial of prenatal nutritional supplementation in New York City. Pediatrics 65:683-697.

Russell, F.

I975 The Pima Indians. Reprint. University of Arizona Press, Tucson. Rye, Owen $S$.

I98 I Pottery Technology: Principles and Reconstruction. Taraxcum, Washington, D.C.

Sahlins, Marshall

I972 Stone Age Economics. Aldine, Chicago.

Sanders, William T., Jeffrey R. Parsons, and Robert S. Santley

I979 The Basin of Mexico: Ecological Processes in the Evolution of a Civilization. Academic Press, New York. 
SANM. See Spanish Archives of New Mexico

Schaafsma, Curtis F.

I974 The Hatch Site: Archaeological Salvage Excavations on Interstate Highway 25, Dona Ana County, New Mexico. Museum of New Mexico Laboratory of Anthropology Notes 96. Santa Fe.

I979 The "El Paso phase" and its relationship to the "Casas Grandes phenomenon." In Jornada Mogollon Archaeology: Proceedings of the First Iornada Conference, edited by Patrick H. Beckett and Regge N. Wiseman, 383-388.

Schaafsma, Polly

I980 Indian Rock Art of the Southwest. University of New Mexico Press, Albuquerque.

Schaafsma, Polly, and Curtis F. Schaafsma

I 974 Evidence for the origin of the Pueblo Kachina cult as suggested by southwestern rock art. American Antiquity 39:535-545.

Schmidt-Couzzourt, Beverly

I983 The Chicken-Creek Site: Archaeological Testing in the Lake Meredith Recreation Area, Potter County, Texas. U.S. Department of the Interior, Bureau of Reclamation, Southwest Region, Amarillo.

Schmitt, Karl H.

I950 The Lee site, GV-3, of Garvin County, Oklahoma. Texas Archaeological and Paleontological Society Bulletin $2 \mathrm{r}: 69-89$.

Schoenwetter, James, and Frank W. Eddy

I964 Alluvial and Palynological Reconstruction of Environments, Navajo Reservoir District. Museum of New Mexico Papers in Anthropology I 3 . Santa Fe.

Schorger, A. W.

I966 The Wild Turkey: Its History and Domestication. University of Oklahoma Press, Norman.

Schortman, Edward W., and Patricia A. Urban

I987 Modeling interregional interaction in prehistory. In Advances in Archaeological Method and Theory, vol. II, edited by Michael Schiffer, 37-97. Academic Press, New York.

Schroeder, Albert $\mathrm{H}$.

I972 Rio Grande ethnohistory. In New Perspectives on the Pueblos, edited by Alfonso Ortiz, 4 I-70. University of New Mexico Press, Albuquerque.

I979 Pueblos abandoned in historic times. In Handbook of North American Indians, vol. 9: Southwest, edited by Alfonso Ortiz, 236-254. Smithsonian Institution, Washington, D.C.

Schuldenrein, Joseph

I985 Geomorphological and Geoarchaeological Investigations: Fort Carson-Pinon Canyon Maneuver Site, Las Animas County, Colorado. Final Report 2655. Gilbert/Commonwealth Inc., Jackson, Mich. 
Science Applications, Inc.

I982 A Cultural Resource Inventory of the John Martin Reservoir, Colorado. Report submitted to the U.S. Army Corps of Engineers,

Secoy, Frank Albuquerque District.

1953 Changing Military Patterns on the Great Plains. Monographs of the American Ethnological Society, No. 2I. University of Washington Press, Seattle.

Seni, Steven J.

1980 Sand-Body Geometry and Depositional Systems, Ogallala Formation, Texas. Reports of Investigations No. I05. Bureau of Economic Geology, University of Texas, Austin.

Service, E.

I962 Primitive Social Organization. Random House, New York.

Sharrock, Floyd W.

I96 I The Grant site of the Washita River Focus. Oklahoma Anthropological Society Bulletin 9: $\mathrm{I}-66$.

Shepard, Anna O.

I942 Rio Grande glaze paint ware: A study in illustrating the place of ceramic technological analysis in archaeological research. Carnegie Institution Contributions to American Anthropology and History 7 (39): 1 29-262.

I965 Rio Grande glaze-paint pottery: A test of petrographic analysis. In Ceramics and Man, edited by Frederick R. Matson, 62-87. Viking Fund Publications in Anthropology. Wenner-Gren Foundation for Anthropological Research, New York.

Shinkle, J. D.

I970 New Mexican Ciboleros of the Llano Estacado. Hall-Poorbaugh Press, Roswell, New Mexico.

Simmons, Marc

I983 The great Taos trade fair. New Mexico Magazine 6I (9): 30-33, 50 .

I985 The Chacon economic report of 1803 . New Mexico Historical Review 60 (I): $8 \mathrm{I}-88$.

Simmons, Marc, and Frank Turley

1980 Southwestern Colonial Ironwork: The Spanish Blacksmithing Tradition from Texas to California. Museum of New Mexico Press, Santa Fe.

Smith, Carol A., ed.

I976 Regional Analysis. 2 vols. Academic Press, New York.

Smith, M. Estellie

I983 Pueblo councils: An example of stratified egalitarianism. In Development of Political Organization in Native North America: 1979 Proceedings of the American Ethnological Society, edited by Elisabeth Tooker, 32-44. American Ethnological Society, Washington, D.C. 
Smith, Watson

1952 Kiva Mural Decorations at Awatovi and Kawaika-a, with a Survey of Other Wall Painting in the Pueblo Southwest. Papers of the Peabody Museum of American Archaeology and Ethnology 37.

Snow, David H. Harvard University, Cambridge, Mass.

I976 Archeological excavations at Pueblo del Encierro: $L A$ 70, Cochiti Dam Salvage Project, Cochiti, New Mexico; Final Report, I964I965 Field Seasons. Laboratory of Anthropology Notes No. 78. Museum of New Mexico, Santa Fe.

I98 I Protohistoric Rio Grande Pueblo economics: A review of trends. In The Protohistoric Period in the North American Southwest, $A D$ I 450-I700, edited by D. R. Wilcox and W. B. Masse, 354-377. Arizona State University Anthropological Research Paper 24. Tempe.

I984 Prologue to Rio Grande protohistory. In Collected Papers in Honor of Harry L. Hadlock, edited by N. L. Fox, I25-1 32. Papers of the Archaeological Society of New Mexico 9. Albuquerque Archaeological Society Press, Albuquerque.

I990 Tener Comal y Metate: A preliminary review of protohistoric Rio Grande maize use and diet. In Perspectives on Southwestern Prehistory, edited by Paul E. Minnis and Charles L. Redman, 28930r. Westview Press, Boulder, Colo.

n.d. Rio Grande Ceramics from the Ozier Site. Manuscript on file at Soffer, Olga the Killgore Research Center, West Texas State University.

I989 Storage, sedentism and the Eurasian Palaeolithic record. Antiquity 63:719-732.

Southwest Traditional Crop Conservancy Garden and Seed Book

I 982 Seed Sources and Resources: Meals for Millions. Tucson.

Spanish Archives of New Mexico (SANM), vol. II

I 805 Accounts of articles distributed to allied Indians. Doc. no. I9Io.

I 8 I 3 Comancheros return to San Miguel del Vado. Doc. no. 2492.

I 8 I 4 Proceedings against Cordero and Gonzales. Doc. no. 2542.

Spencer, Robert F, and Jesse Jennings

I965 The Native Americans: Prehistory and Ethnology of the North American Indian. Harper and Row, New York.

Speth, John D.

I983 Bison Kills and Bone Counts: Decision Making by Ancient Hunters. University of Chicago Press, Chicago.

I $987 \mathrm{a}$ Early hominid subsistence strategies in seasonal habitats. Journal of Archaeological Science I 4: 1 3-29.

I $987 \mathrm{~b}$ Les strategies alimentaires des chasseurs-cueilleurs. La Recherche I 8 (I90): 894-903.

I989 Early hominid hunting and scavenging: The role of meat as an energy source. Journal of Human Evolution I 8:329-343.

I990 Seasonality, resource stress, and food sharing in so-called "egali- 
tarian" foraging societies. Iournal of Anthropological Archaeology 9:1 48-I 88 .

Speth, John D., and Alison E. Rautman

n.d. Farmers as Hunters in the Pecos Valley. University of Michigan Museum of Anthropology, Technical Report (in preparation). Ann Arbor.

Speth, John D., and Susan L. Scott

I 985 a Late prehistoric subsistence change in southeastern New Mexico: The faunal evidence from the Sacramentos. In Proceedings of the Third Jornada-Mogollon Conference, edited by Michael S. Foster and Thomas C. O'Laughlin, $137-148$. Artifact $23(\mathrm{I}-2)$.

$1985 \mathrm{~b}$ The role of large mammals in late prehistoric horticultural adaptations: The view from southeastern New Mexico. In Contributions to Plains Prehistory: The 1984 Victoria Symposium, edited by David Burley, 233-266. Occasional Paper 26. Archaeological Survey of Alberta, Edmonton.

r 989 Horticulture and large-mammal hunting: The role of resource depletion and the constraints of time and labor. In Farmers as Hunters: The Implications of Sedentism, edited by Susan Kent, 7 I-79. Cambridge University Press, Cambridge.

Speth, John D., and Katherine A. Spielmann

I 983 Energy source, protein metabolism, and hunter-gatherer subsistence strategies. Journal of Anthropological Archaeology 2: I - 3 I.

Spicer, Edward $\mathrm{H}$.

I962 Cycles of Conquest: The Impact of Spain, Mexico, and the United States on the Indians of the Southwest. University of Arizona Press, Tucson.

SpieImann, Katherine A.

I982 Inter-Societal Food Acquisition Among Egalitarian Societies: An Ecological Study of Plains/Pueblo Interaction in the American Southwest. Ph.D. diss., Department of Anthropology, University of Michigan, Ann Arbor.

I983 Late prehistoric exchange between the Southwest and southern Plains. Plains Anthropologist 28 (I02): 257-272.

I 986 Interdependence among egalitarian societies. Journal of Anthropological Archaeology 5:279-3 I 2 .

I988 Changing Faunal Procurement Strategies at Gran Quivira Pueblo, New Mexico. Paper presented at the Society for American Archaeology 53rd Annual Meeting, Phoenix, Arizona, May 1988.

I989a Colonists, hunters, and farmers: Plains-Pueblo interaction in the seventeenth century. In Columbian Consequences, vol. I, edited by David H. Thomas, 103-I I3. Smithsonian Institution Press, Washington, D.C.

I $989 \mathrm{~b}$ A review: Dietary restrictions on hunter-gatherer women and the implications for fertility and infant mortality. Human Ecology I 7:32I-345.

1990 Clustered Confederacies: Socio-Political Organization in the 
Protohistoric Rio Grande. Paper presented at the Southwest Symposium, Albuquerque, January I 2-1 3, I 990.

I99 I Interdependence in the Prehistoric Southwest: An Ecological Analysis of Plains-Pueblo Interaction. Garland, New York.

Sprague, Roderick, and Aldo Signori

I963 Inventory of prehistoric southwestern copper bells. Kiva 28 (4): $\mathrm{I}-20$.

Stefansson, Vilhịalmur

I944 Arctic Manual. Macmillan, New York.

I956 The Fat of the Land. Macmillan, New York.

Story, Dee Ann

I98 I An overview of the archaeology of east Texas. Plains Anthropologist 26 (92): I 39-I 56.

Stresser-Pean, Guy

I97 I Ancient sources on the Huasteca. In Handbook of Middle American Indians, edited by Robert Wanchope; vol. 2: Archaeology of Northern Mesoamerica, pt. 2, edited by Gordon F. Ekholm and Ignacio Bernal, 582-602. University of Texas Press, Austin.

Stuart, David E., and Rory P. Gauthier

I98I Prehistoric New Mexico: Background for Survey. State of New Mexico, Historic Preservation Bureau, Office of Cultural Affairs, Santa Fe.

Studer, Floyd V.

I93 I Archaeological survey of the north Texas Panhandle. Bulletin of the Texas Archaeological and Paleontological Society 3:70-75.

I934 Texas Panhandle Culture Ruin No. 55. Bulletin of the Texas Archaeological and Paleontological Society 6:80-96.

Suhm, Dee Ann

I962 The White site: An historic Indian burial in Yoakum County, Texas. Bulletin of the Texas Archaeological Society 32:85-I I 9.

Swenson, Fern E.

I986 A Study in Cultural Adaptation to Climatic Shifts on the Southern Plains: Washita River Phase and Edwards Complex Cultural Continuity. M.A. thesis, University of Oklahoma, Norman.

Switzer, Ronald R.

I 969 Tobacco, Pipes and Cigarettes of the Prehistoric Southwest. El Paso Archaeological Society, Special Report 8. El Paso.

Tafoya, Jose Piedad

I893 Deposition of Jose Piedad Tafoya, June 26, I 893. Indian Depredation Claims Case File No. 9I33. Records of the U.S. Court of Claims, Record Group 2 I. National Archives, Washington, D.C.

Taylor, Anna Jean

I976 Pastores in the Texas Panhandle, I876-I884. Honors Paper, Wayland Baptist College, Plainview, Tex.

I980 A survey of New Mexican Pastores in the Texas PanhandlePlains, I 876-I 886. Manuscript on file, Texas Historical Foundation, Austin. 
Templeton, A. R., and L. E. Gilbert

I 985 Population genetics and the coevolution of mutualism. In The Biology of Mutualism, edited by D. H. Boucher, I 28-1 44. Croom Helm, London.

Thomas, A. B.

I929 Documents bearing upon the northern frontier of New Mexico, I 8I8-18 19. New Mexico Historical Review 4: I46-I 77.

I932 Forgotten Frontiers: A Study of the Spanish Indian Policy of Don Juan Bautista de Anza, I777-1787. University of Oklahoma Press, Norman.

I935 After Coronado. University of Oklahoma Press, Norman.

I940 The Plains Indians and New Mexico, 175I-1778: A Collection of Documents Illustrative of the History of the Eastern Frontier of New Mexico. University of New Mexico Press, Albuqueruqe.

Thompson, J. N.

I982 Interaction and Coevolution. John Wiley and Sons, New York.

Tichy, Mariorie Ferguson

I939 The archaeology of Puaray. El Palacio 46 (7): I 45-I63.

Tierson, F. D., C. L. Olsen, and E. B. Hook

I985 Influence of cravings and aversions on diet in pregnancy. Ecology of Food and Nutrition I 7: I I 7-1 29.

Tuan, Yi-Fu, C. E. Everard, J. G. Widdison, and I. Bennett

I973 The Climate of New Mexico. Rev. ed. State Planning Office, Santa Fe.

U.S. Department of Agriculture. Weather Bureau

I932 Climatic Summary of the United States: Sections 27-28, Northwestern and Northeastern New Mexico. Edited by R. J. Martin. Government Printing Office, Washington, D.C.

Upham, Steadman

I 982 Polities and Power. Academic Press, New York.

I984 Adaptive diversity and southwestern abandonment. Journal of Anthropological Research 40 (2): 235-256.

I 986 Smallpox and climate in the American Southwest. American Anthropologist 88 (I): I I 5-I 28

I987 Understanding the disease history of the Southwest: A reply to Reff. American Anthropologist 89 (3): 708-710.

Upham, Steadman, and Fred Plog

I986 The interpretation of prehistoric political complexity in the central and northern Southwest: Toward a mending of the models.

Vehik, Susan C. Journal of Field Archaeology I 3 (2): 223-238.

I977 Bone fragments and bone grease manufacturing: A review of their archaeological use and potential. Plains Anthropologist 22 (77): I69-I 82 .

Vickers, William T.

1980 An analysis of Amazonian hunting yields as a function of settlement age. In Working Papers on South American Indians, vol. 2, 
edited by R. B. Hames, 7-29. Bennington College, Bennington, Vt.

Wallace, Ernest

I964 Ranald S. MacKenzie on the Texas Frontier. West Texas Museum Association, Lubbock.

I967 Ranald S. MacKenzie's Official Correspondence Relating to Texas, I87I-I875. West Texas Museum Association, Lubbock.

Wallace, Ernest, and E. Adamson Hoebel

I952 The Comanches: Lords of the South Plains. University of Oklahoma Press, Norman.

Wallerstein, Immanuel

I974 The Modern World-System: Capitalist Agriculture and the Origins of the European World-Economy in the Sixteenth Century. Academic Press, New York.

I 979 The rise and future demise of the world capitalist system: Concepts for comparative analysis. In The Capitalist World-Economy, I-36. Cambridge University Press, Cambridge.

Warren, A. Helene

1969 Tonque. El Palacio $76(2): 36-42$.

Warren, A. Helene, and Frances Joan Mathien

I 985 Prehistoric and historic turquoise mining in the Cerrillos district: Time and place. In Southwestern Culture History: Collected Papers in Honor of Albert H. Schroeder, edited by Charles H. Lange, 93-1 27. Papers of the Archaeological Society of New Mexico Io.

Warren, Claude N. Albuquerque.

I984 The Desert region. In California Archaeology, edited by Michael J. Moratto, 339-430. Academic Press, New York.

Watson, Virginia

I950 The Optima Focus of the Panhandle Aspect: Description and analysis. Bulletin of the Texas Archaeological and Paleontological Society 2r:7-68.

Weber, David J.

I967 Albert Pike: Prose, Poems, and Sketches. Calvin Horn, Albuquerque.

I97 I The Taos Trappers. University of Oklahoma Press, Norman.

Wedel, Mildred $M$.

I982 The Indian they called Turco. In Pathways to Plains Prehistory: Anthropological Perspectives on Plains Natives and Their Pasts, edited by Don G. Wyckoff and Jack L. Hofman, I 53-162. Oklahoma Anthropological Society Memoir 3. Cross-Timbers Heritage Association Contributions I. Cross Timbers Press, Duncan, Oklahoma.

Wedel, Waldo R.

1942 Archaeological Remains in Central Kansas and Their Possible Bearing on the Location of Quivira. Smithsonian Miscellaneous Collections Ior, Washington, D.C. 
I950 Notes on Plains-Southwestern contacts in light of archaeology. In For the Dean: Essays in Anthropology in Honor of Byron Cummings, edited by E. K. Reed and D. S. King, 99-I I6. Hohokam Museums Association, Tucson.

I959 An Introduction to Kansas Archaeology. Bureau of American Ethnology Bulletin 174 . Washington, D.C.

I 983 The prehistoric Plains. In Ancient North Americans, edited by Jesse D. Jennings, 202-24I. W. H. Freeman, San Francisco.

I986 Central Plains Prehistory: Holocene Environments and Culture Change in the Republican River Basin. University of Nebraska Press, Lincoln.

Weigand, Phil C., Garman Harbottle, and Edward V. Sayre

I977 Turquoise sources and source analysis: Mesoamerica and the southwestern U.S.A. In Exchange Systems in Prehistory, edited by Timothy K. Earle and Jonathan E. Ericson, I5-34. Academic Press, New York.

Weltfish, Gene

I 965 The Lost Universe. Basic Books, New York.

Wendorf, Fred

I953 Salvage Archaeology in the Chama Valley, New Mexico. Monographs of the School of American Research I7. Santa Fe.

I960 The archaeology of northeastern New Mexico. El Palacio 76:2I 2.

Wendorf, Fred, and Erik K. Reed

I955 An alternative reconstruction of northern Rio Grande prehistory. El Palacio 68 (5-6): I 3 I-I 73.

Wetterstrom, Wilma

I986 Food, Diet, and Population at Prehistoric Arroyo Hondo Pueblo, New Mexico. Arroyo Hondo Archaeological Series 6. School of American Research Press, Santa Fe.

Whipple, A. W.

I 853- Report of explorations for a railway route, near the thirty-fifth 54 parallel of north latitude from the Mississippi River to the Pacific Ocean. In Reports of Explorations and Surveys to Ascertain the Most Practicable and Economical Route for a Railroad from the Mississippi River to the Pacific Ocean, vol. 3. 33d Congress, 2d Session, House of Representatives Executive Document 9I. Washington, D.C.

White, L.

1935 The Pueblo of Santo Domingo. American Anthropological Society Memoir 43.

Whitney, E. N., and E.M.N. Hamilton

I 984 Understanding Nutrition. $3 \mathrm{~d}$ ed. West Publishing Company, St. Paul, Minn.

Whittlesey, Stephanie $M$.

I 983 Uses and abuses of Mogollon mortuary data. In Recent Research in Mogollon Archaeology, edited by Steadman Upham, Fred Plog, 
Wilcox, David R.

David Batcho, and Barbara Kauffman, 276-284. University $\mathrm{Mu}-$ seum, New Mexico State University, Las Cruces.

I98Ia Changing perspectives on the protohistoric Pueblos, AD I450I 700. In The Protohistoric Period in the North American Southwest, AD I450-I700, edited by D. R. Wilcox and R. B. Masse, 378-409. Arizona State University Anthropological Research Paper 24. Tempe.

I98 Ib The entry of Athapaskans into the American Southwest: The problem today. In The Protohistoric Period in the North American Southwest, AD I450-I700, edited by D. R. Wilcox and R. B. Masse, 213-256. Arizona State University Anthropological Research Paper 24. Tempe.

I984 Multi-ethnic division of labor in the protohistoric Southwest. Papers of the Archaeological Society of New Mexico 9:14 I-I 56.

I986a A historical analysis of the problem of Southwestern-Mesoamerican connections. In Ripples in the Chichimec Sea, edited by Frances Joan Mathien and Randall H. McGuire, 9-44. Southern Illinois University Press, Carbondale.

I986b The Tepiman connection: A model of Mesoamerican-southwestern interaction. In Ripples in the Chichimec Sea, edited by Frances Joan Mathien and Randall H. McGuire, I35-I 53. Southern Illinois University Press, Carbondale.

I 988 A Processual Model of Charles C. Di Peso's Babocomari Site and Related Systems. Manuscript on file at the Museum of Northern Arizona, Flagstaff.

Wilcox, David R., and Lynette O. Shenk

I977 The Architecture of the Casa Grande and Its Interpretation. Arizona State Museum Archaeological Series I I 5. University of Arizona, Tucson.

Wilcox, David R., and Charles Sternberg

I983 Hohokam Ballcourts and Their Interpretation. Arizona State $\mathrm{Mu}$ seum Archaeological Series I6o. University of Arizona, Tucson.

Wilkerson, S. Jeffrey $\mathrm{K}$.

I 985 Sacrifice at Dusty Court: Evolution and diffusion of the ritual ball game of northeastern Mesoamerica. In International Symposium on the Mesoamerican Ballgame, assembled by David R. Wilcox and Vernon Scarborough, 64-I I 5. Manuscript on file at the Arizona State Museum Library, University of Arizona, Tucson.

Williams-Dean, Glenna J.

I978 Ethnobotany and Cultural Ecology of Prehistoric Man in Southwest Texas. Anthropology Research Laboratory, Texas A\&M University, College Station.

Wilson, Gilbert L.

I917 Agriculture of the Hidatsa Indians: An Indian Interpretation. University of Minnesota Studies in the Social Sciences 9. Minneapolis. 
Winick, $M$.

I 989 Nutrition, Pregnancy, and Early Infancy. Williams and Wilkins, Baltimore.

Winkler, Barbara A.

I 982 Wild Plant Foods of the Desert Gatherers of West Texas, New Mexico and Northern Mexico: Some Nutritional Values. M.A. thesis, Department of Anthropology, University of Texas, Austin.

Winship, George P.

I896 The Coronado Expedition, I540-I542. Bureau of American Ethnology Annual Report I4, pt. I.

Winter, Joseph C.

I 976 The processes of farming diffusion in the Southwest and Great Basin. American Antiquity 4I:42 I-429.

I986 New Evidence on the Arrival of the Athabascans in the Southwest and Western High Plains. Paper presented at the I 986 Navajo Studies Conference, Albuquerque.

Winterhalder, $B$.

I98 I Optimal foraging strategies and hunter-gatherer research in anthropology: Theory and models. In Hunter-Gatherer Foraging Strategies, edited by B. Winterhalder and E. A. Smith, I3-35. University of Chicago Press, Chicago.

Winterhalder, Bruce, and E. A. Smith, eds.

I98I Hunter-Gatherer Foraging Strategies. University of Chicago Press, Chicago.

Wiseman, Regge N.

I985 Bison, fish, and sedentary occupation: Startling data from Rocky Arroyo (LA 25277), Chaves County, New Mexico. In Views of the Jornada Mogollon, edited by Colleen M. Beck, 30-32. Eastern New

Witty, Tom Mexico University Contribution in Anthropology I2. Portales.

I 977 The 1977 Kansas Anthropological Association dig and Kansas archaeology training program: The Tobias dig. Kansas Anthropologi-

Woodburn, James cal Association Newsletter 23 (I): I-7.

I988 African hunter-gatherer social organization: Is it best understood as a product of encapsulation? In Hunters and Gatherers, vol. I: History, Evolution and Social Change, edited by T. Ingold, D. Riches, and J. Woodburn, 3 I-64. Berg, Oxford.

Woosley, Ann I.

I980 Agricultural diversity in the prehistoric Southwest. Kiva 45 (4): $317-336$.

Word, James $\mathrm{H}$.

I963 Floydada Country Club site 4I-FL-I. Bulletin of the South Plains Archeological Society 1:37-63.

I965 The Montgomery site in Floyd County, Texas. Bulletin of the South Plains Archeological Society 2:55-102. 
Word, James $H_{\text {, }}$ and Anne Fox

I975 The Cogdell burial in Floyd County, Texas. Bulletin of the Texas Archaeological Society 46:I-67.

Worthington-Roberts, B., and S. R. Williams

I989 Nutrition in Pregnancy and Lactation. 4th ed. Times Mirror/

Wray, J. D. Mosby, St. Louis.

I978 Maternal nutrition, breast-feeding and infant survival. In Nutrition and Human Reproduction, edited by W. H. Mosley, 197-229. Plenum, New York.

Wulfkuhle, Virginia

r 984 Analysis of a Sample of the Surface Collected Ceramics from Landergin Mesa, Oldham County, Texas: Phase I Investigations, Fall I981. Manuscript on file at the Texas Historical Commission, Austin.

Wyckoff, Don Gale

I980 Caddoan Adaptive Strategies in the Arkansas Basin, Eastern Oklahoma. Ph.D. diss., Department of Anthropology, Washington State University, Pullman.

Ydenberg, R. C., L.-A. Giraldeau, and D. L. Kramer

1986 Interference competition, payoff asymmetries, and the social relationships of central place foragers. Theoretical Population Biology $30: 26-44$. 


\section{Index}

Acculturation, 68

Acoma Pueblo, 139, I 43, I 5 I

Alibates agate, 42, 94, 98, 106

Alibates Ruin 28, 95, 98, 99, IOI, IO2

Alliances, I I, I 2, I 3, I 4, I 6, 6I, 69, IO2, I $2 I, I 24, I 25$, I 26 , I 3 I, I 52 , I 6I, I 63

Anasazi, 74-75

Antelope, I I, 25, 100, I 64

Antelope Creek phase, 89--106, 109, I I 4-I 5, I 44, I 46-47, I 52

Antelope Creek Ruin 22, 24, 94, I06

Anza, Don Juan Bautista de, I 58 , I 64

Apache. See Athapaskans

Architecture, Plains, 90, 93, I08, I I 4-I 5

Arroyo Hondo Pueblo, $\mathrm{I}_{42}$

Athapaskans, 10, I 5, I 6, 25, 36-39, $4 \mathrm{I}-43,69,7 \mathrm{I}, 74,84-88$, I $4-6$, I 20-26, I 43, I 44, I 47, I 52, I 57, I63-64, I67. See also Western Apache

Bantu, 20

Baugh, Timothy G., 7, IO-I 2, I4, I 30, I 43

Bison: bone at Plains sites, 25, 90, IOO, I O2, I I I-I 3, I I 7-I 8, I 20,
I46; bone at Pueblo sites, 28, 4243, 94, I 45-46, I 50; bone tools, 90, 94, 100, I02; at Casas

Grandes, 150; exchange of meat, $7,8,11,15,16,42-45,47-52,56$, $57,6 \mathrm{I}, 67,69,70,78,84,85,90$, 94, I00, I02, 103, I05, I07, I I II 3, I I 5-I 8, I 20, I 2 I, I 24, I 25 , I43, I 45, I46, I 50; hides, 8, 24, 46,94, I 43, I 46, I 56-59, I 60, I6I, 164-65, I 68; hunting, 22, 24, $25,28,42,43-48,57,69,90,103$, I 07, I I I-I 3, I I 5-I 7, I 20, I 45, I46, I 50; restriction of access to, $42,45-48$; specialization on procurement, $16,22,31-34,44$, I05

Blanco Canyon, Texas, 57, 65

Buffering models, 4-5, I 3-I 4, I6, I 8-I9, IO3, IO5

Cache pits, 85, 90, I09, I I I, I I 4, I I 9-20

Caddoan-Plains exchange, I 2, 94 , I04, I I 5, I 44-45

Caddoans, I2, I 5, 33, 94, 105, 108$23, I 25, I 26, I 44, I 45, I 46$

Calumet Ceremony, IO3

Canadian River Valley, 44, 63, 92, 93, 95, I03-5, I I 5, I 44

Carbohydrates, 24, 28-29, 3I, 46-47 
Casas Grandes, I 2, I 4, IOI, IO2, I 3 I, I 39, I 43, I 46-5 I

Castañeda, 7, 152

Catlin, George, I 60

Cattle rustling, I6I-62

Central place foraging, 26, 43-46

Ceramics: Biscuit ware, I 28, I 4 I43; Caddoan, 58; Chihuahuan polychromes, I 46, I49; for cooking, 54, 69; cordmarked, 90, 94, 98; corrugated, 55; Crockett Curvilinear, 94; culinary, 53-55; distribution on Plains, 8, 1 3, 53$56,68,75,95-97$, I 20, I 66-68; distributions within Rio Grande Valley, I 28, I 32-43, I 5 ; Edwards Plain, 58; El Paso Polychrome, I 39, I 44-45, I 49-50; Gila Polychrome, I 49-50; Little Deer Plain, 58; mineralogical analysis, 52, 63-67; Plains production of, $52,56,58,62-70$, I04; Rio Grande glazewares, 36, 53-58, 68, 96-97, I 20, I 28, I 33-39, I 44, 157; Rio Grande Striated, 55-70; Tierra Blanca Plain, 58-70; trade to Plains, 7, 5 I-56, 67-68, 89, 94-95, 98-I00, 104; Tularosa Black-on-white, 1 39; use on Plains, 53-54, 56, 69, 89, 94-95, 98, I 00, I04; vessel forms on Plains, 53-54

Chaco Canyon, 25, 26, 72, I39, I 5 I Chamuscado-Rodriguez expedition, 7, 133

Chimney Rock, Colorado, 77-80, 98, 99

Chimney Rock Ruin, Texas, 98, 99

Ciboleros, 45, I 60

Climate, relating to exchange, $4, I_{3}$, I 5-I6, I05, I I 5

Coevolution, $3, \mathrm{I}_{3}$

Colorado, 72, 75, 77, 78, 79, 87, 92

Colorado Plateau, 4, I 5, I 29, I 43, 149

Comanche, $14-16,36,45,122-24$, I 26, I 55-65, I 68
Comanchero trade, I 4, I 55, I 56, 158-68

Competition: for access to bison, 37, 45-49; for marriage partners, 2 I ; Plains-Anglo, I68; PlainsPueblo, I 3, 24, 37, I 52; between Pueblos, 49, I23, I33, I 52, I 68

Conflict: models concerning, 40; on Plains, 93, 103, I 21, I 46; PlainsPueblo, 36-39, 40, I 52

Corn: at Chimney Rock, 78-79; green, 23, 24, 7I, 73, 75, 78-80, $83-86,88$, I44; growing season, $72,75-83$; processing of, 54,69 ; production of, among Plains populations, I00, I02, I07, I09IO, II 4, I I 8; production of, among Southwestern populations, I I, 7 I -88 , I 2O-2 I, I 39; raid for, 38-4I; seed, I4, 7I, $73,75,78,85-88$; storage of, $23-$ 24, I I 8-20; trade of, 8, IO-II, I 4-I 5, 47, 49, 54, 7 I, 78-79

Coronado, Juan Vasquez de, 7,36 , 40, I I 6, I 33, I 52, I 53

Cotton, $7,143,144,146$

Cree, 44

Custer phase, I I I

Deer, I I, 25, 44, I 00, I I I, I I 3, I I 5, I 25, I 57, I 64, I 65

Defense, by Pueblos, 36, 38, 4I, I 38 de Sosa expedition, 7

Diffusion, I0, 70

Dog transport, Plains, 47

Eastern agricultural complex, I09

Ecological models, 4-7, IO-I I, 37, $40,43-48$, I 30 ; central place foraging, $26,43-48$

Egalitarian society, I

Espejo, Antonio, I 32, I 33, I 39, I4 I

Ethnic groups, I 2, 14, I 5, I 28-43

Exchange, 2-8, 10-16, I 8, 19, 21 , $22,24,27,28,3$ I $33,34,42,44$, $49,5 \mathrm{I}-53,69-7 \mathrm{I}, 78,85,86,88-$ $90,92,94$, IOO, IOI, IO2-5, IO7, 
I I 3, I 2O, I 22, I 24, I 25, I 43, I 44, I 50, I 54-58, I6I, I65, I 68; and climatic change, $4,13,15-16$, I05, I I 5 ; between farmers, I 3,7 I, $74,94,100$; between huntergatherers and farmers, $17,20-33$; of labor, 2O-2 I; of marriage partners, 20-22, MesoamericanSouthwest, I 30; mutualistic, 4, 5 , I I--I6, I 9, 24, 27-28, 33, 37, 49, 7I, IO4, I 3 I-32, I 50, I 54, I 56 ; and resource distribution, 4-5; creation of social ties, $3-5$, I I ; theoretical approaches, $3-7$, Io, I30; among tribal societies, 3. See also Caddoan-Plains exchange; Plains-Anglo exchange; PlainsMexican exchange; Plains-Pueblo exchange; Plains-Spaniard exchange

Farming: Athapaskan, 74, 84, I 2426; Hidatsa, 84, 86-87; Hopi, 72 , 75-76, 85-86; Navajo, 76; Pima Bajo, 86 ; Ute, 85

Fats, 28-29, 3I, 46, 54

Footprint site, 93, I02, 103

Fulton Aspect, I $31,144,146$

Galisteo Basin pueblos, 7, 10, 4I, $59,67,120$, I 2 I, I 25, I 43, I 5 I52,156

Garza complex, 56-58,63, 65, 69, I04, IO5, I I 6, II 8, I 20 , I2 I

Gibson Aspect, I3 I, I 46

Glaze A period, I 39-4I, 144

Glaze E period, 53, 55, I 33, I 39-4I, 152

Glazewares, 36, 53-58, 68, 96-97, I 20, I 28, I 33-39, I 44, I 57

Gran Quivira, Io, I I, 28, 36, 4I, 43, I 43, I 46

Great Bend Aspect, I I 6, I I 9

Gregg, Josiah, I 60-62

Growing season. See Corn: production of, among Plains populations; production of, among Southwest populations

Hatch's Ranch site, I 66

Heerwald site, I I I, I I 4

Henderson Pueblo, 28, I 45

Hidatsa, 84, 86-87

Hinds Cave, I I 4

Historic period, I 3, I 4, I 22-24, I 26, I 55-69

Holden, W. C., 8,28

Honey, $2 \mathrm{I}$

Hopi, 72, 75-77, 85-86, I 5 I

Hunger seasons, 19, 22-24, 33

Hunting: communal, 27, I 5 ;

emphasis on large game, 25-26;

by farmers, 20, 25; by Plains

farmers, 90, 92, 100, 102, 107 , I I I-I 8, I 45-46; by Plains nomads, $32-34$; by Pueblo farmers, II, 27-28, 33, 47-48, I 18 . See also Bison: hunting; Over-hunting

Hypergyny, 19-22, 33

Interaction, 3, 100, I 39

Interdependence, 2, 5, I 2

Interference competition, 45-48

Ituri Forest, 20

James, Thomas, I 60

Jelinek, Arthur I., Io

Jumanos, 8, I45, I 50, I 53, I 57

Kachina cult, I 5 I

Kansas, 8, IO, I I, I 2, 84, I I 9

Kavanaugh, Thomas, 162-64

Kelley, J. Charles, 8-9

Kelley, Jane Holden, 9, 28, I45

Kenner, Charles, I 68

Krieger, Alex D., I 44-46

Landergin Mesa, 95, 100

Late Elmendorf phase, I 38-39

Late Prehistoric period, I 3, 25, 27, $42,53,78,89,92,94$, IOI-5, I 28 , I 3I, I 43-47 
Lincoln phase, I 45-46, I 50

Llano Estacado, 57, 63-65, I05, I 31, I 44, I 45, I 50

McGarraugh Ranch, 95, 98 Macroeconomies, 104, I07, I22, I 26, I 3O, I 3 I, I 39, I 43-52, I 54

Marcy, Colonel Randolph, I 17

Merrell-Taylor site, I 67

Mesa Verde, 4I, 79

Milligan Gulch site, I 39-40

Mutualism, 4, 5, I I-I6, 19, 37, 49, 7 I, I04, 105, I 5I, I 54, I 56

Navajo, 36-37

Nonhierarchical society, I-7

Nutritional stress, 22-23, 29-3I

Obsidian, 8, I 5, 5 I, 94-95, 98, I00, IOI, IO4, I I 3, I 2O, I 25

Obsidian hydration, 57

Ogallala aquifer, 92,93

Ogallala formation, $63-64,66$

Okiek, 2 I

Oñate, Don Juan de, 8, 129, I 43

Osage Savanna, I08, I I I

Over-hunting, I I, 26-27, 33

Pa-ako, 60

Paquimé. See Casas Grandes

Paquimé macroeconomy, I47-50

Patarabueye, 8, I 50

Pawnee, I I 9

Pecos Pueblo, 7, 8, 9, IO, I I, 25, 28, $34,36,4 \mathrm{I}, 55,59-60,67,76$, I 2 I, I 23, I 24, I 3 I, I 43, I 5 I-53, I 54, I 56, I 58, I 59, I 63, I 64

Picurís Pueblo, 7, 8, I0, 76, I23, I 43, I 44, I 56, I63, I 67

Piña (Pilabó), I 40

Pipes: elbow, 94, 98, 100; Pueblo, 94, 95, 98, 99, IOO, IOI, IO3, IO4; stone, $98-99$

Piro, I 3 I-4I

Plains: architecture, 90, 93, 108, I I 4-I 5; paleoenvironment, 90, 92, IO2, I I 4, I I ; settlement patterns, 90, 93, I03, I05;

subsistence, 90, I00, I02, I09-2I, I 25

Plains-Anglo exchange, I $6 \mathrm{I}-62$

Plains-Mexican exchange, I 59-6 I

Plains-Pueblo exchange, $2-3,7-8$, I I-I 4; archaeological evidence of, 8-IO, I8, 36, 5I, 53,93-IOI, I I 3 , I 20, I 44-45, I65-68; changes in, $\mathrm{I} 3-17,103-5,108$, I I 5, I 21, I 25, I 44-47; context of, IO2-3; demographic variables affecting, I 5, 27-28, 33, 47, IOI ; ecological aspects of, I 5 ; ethnohistoric documentation of, $7-8$, I 8, I 9, 2 I-22, 25, 34, 52, $67-68,156$; explanations of, 10I 3, I 8, I 57, I62-65, I 68;

Hispanic effect on, I 5-I6, I07, I 22-24, I 26; historic trade fairs, 1 3, I 23-24, I 45, I 56-58, I63-64; intensity of, I 2, I4-I 5, I 8, 94, IOO-IOI, II3, I20; previous research on, $8-13,28$; season of, 7, 24-25, I 44; simulation of, I I, 28; Southern Plains macroeconomy and, I I, IO4, I07, I 22, I 26, I 3 I, I 43-46, I 52, I 54 ; technological impact of, 5 I, 68-70

Plains-Pueblo hostilities, $36-38,40$, IO3

Plains-Spaniard exchange, I 3-I 4, I 6-I 7, I 22-24, I 55-59

Plains Villager period, $25,5 \mathrm{I}, 57,58$, $69,70,89-126$

Plains Woodland period, 25

Plant foods, Plains, 32, 46-47, 54, I00, I09-I 4

Projectile points, Plains, 90, 100, I02, I06, I 61, I67

Protein, II, I 5, I9, 20, 24-34, 46, 47,7 I, 88, I I 5, I I 7, I 2 I, I 43; consumption by pregnant women, 29-3I; limits on consumption, 29-3I ; strategies to acquire, 27 
Protohistoric period, $8,10-15,26$, $36,42,5 \mathrm{I}-70,89,104-6$, IO7-2I, I 25-26, I 44-45

Puaray, 6o

Pueblo: political organization, 7, I I, I 29--3 I, I 39-4I, I 5 I-54; population size, I $29-30$, I 40 , I 5 i settlement patterns, I 29 , I 3 I -43, I 50

Pygmies, 20-24, 33

Quivira, 153

Rabbits, 25, I00, I I I, I I 2

Raids, 16, 33, 36-42, 93, I03; archaeological evidence of, $4 \mathrm{I}-$ 42; for livestock, 39; as a subsistence strategy, 38-39, $4 \mathrm{I}$

Rio Grande pueblos, I 2, 1 5, $51-53$, $55,56,60,67,68$, IOI, I2O, I 28 43,156

Rio Grande Valley, I 4, I 5, I 6, 27, $53,71,72$, IOI, I 33, I38, I39, I4I, I49, I5 I, I 6 I ; changing adaptations in, 74-75, 87; interaction with northeastern Pueblo periphery, $74-75$; as periphery of Anasazi world, 74

Risk, 4, I I, 26, 40-4I; in corn production, $75-76,80,83$

Sandbur, I I 4, I 25

Sand Pit site, I 68

San Felipe, 1 39-40

San Juan Pueblo, 7, 85

San Marcos Pueblo, 7, 36, 44, 60

San Pascual, I 39-40

Santa Clara Pueblo, 85, 86

Schortman, Edward W., 3

Settlement patterns, Plains, 90, 93, I03, IOS

Shell ornaments, 36, 42, 5 I, 94, 95, IOO-IOI, IO4, I 48, I 50, I 54

Simulation models, I I , 28, 48

Socorro, I 40

Southern Plains macroeconomy, I I,
I04, I07, I 22, I 26, I 3 I, I 43-44,

I 46, I 50, I 52 , I 54

Spanish colonization, impact on

Pueblo society, 7-8, I 22-24, I 29

Specialization, 5, I 2, I6, 2I, 22, $3 \mathrm{I}$,

$44,52,104-5,148-49$

Spielmann, Katherine A., Io-12, 28

Spiro, I3I, I 46

Stable isotope analysis, 22, 43

Storage pits. See Cache pits

Taos, 8, 10, 77, 86, I I 8, I 23, I 24, I43, I 44, I 56, I 57, I63, I 67

Tarbox Ruin, 95

Tewa, 59, 85, I 3 I, I 4 I-43, I 65

Teyas, I I 6, I 2 I, I 43, I 52

Tierra Blanca complex, 56, 63, 64, $66,69,104$

Tierra Blanca Plain, 58-70; comparisons with Rio Grande Striated, 60-63

Tobacco, 99, 103, I57, I 59, I60, I6I, I 63

Trade. See Exchange

Trade fairs, I 3, I 24, I 45, I 56, I 58, I $63, \mathrm{I} 64$

Tribal society, I, 3, I 26

Turkey, 27, 47, I I I, I 48

Turquoise, 5 I, 95, IOI, I04, I I3, I 20, I 25, I $43, I 44, I 5$ I, I 54

Urban, Patricia A., 3

Vaqueros, 8, I 44, I 56

Wallerstein, Immanuel, 6

Washita River phase, I07-9, I I II 3, I I 5, I 20, I 25

Wedel, Waldo R., 8

Western Apache, 37-39, 87, 88

Wheeler phase, $57,58,63,66,67$, 69, I04, I07, I I 5-2I, I 25

Wichita, I 2, I I9, I 20, I 3 I, I44, I46, I 52, I 53 , I 54

Wilcox, David R., Io, I 2, I 4

World Systems Theory, 6, 7, I0, I 30

Zuni, 84, I 29, I 39, I 5 I 



\section{ABOUT THE EDITOR}

Katherine A. Spielmann received her A.B. from Harvard University in 1976 and her doctorate in anthropology from the University of Michigan in 1982. Since that time she has held a postdoctoral fellowship in the Department of Anthropology at the Smithsonian Institution and was a member of the faculty of the Department of Anthropology at the University of Iowa. In I987 she joined the faculty of the Department of Anthropology at Arizona State University. Dr. Spielmann's research interests concern subsistence strategies of, craft specialization in, and interaction among nonhierarchical societies. The underlying theme of this research is that such societies are often far more economically and socially complex than is generally thought in anthropology. Since 1984 she has conducted fieldwork at two late prehistorichistoric pueblo sites (Gran Quivira Pueblo and Pueblo Colorado) in central New Mexico. The goal of these excavations has been to collect data pertaining to Plains-Pueblo interdependence, subsistence change in Pueblo societies, particularly with regard to hunting, and the evolution of prehistoric craft specialization. Her research on subsistence change has also involved the use of bone chemistry analysis in the reconstruction of prehistoric Pueblo diets. 
